VILNIAUS GEDIMINO TECHNIKOS UNIVERSITETAS

Mantas PRANSKEVIČIUS

\title{
SKIRTINGOS ŽEMĖNAUDOS DIRVOŽEMIŲ BENDROSIOS ANGLIES KIEKIO IR ANGLIES DIOKSIDO EMISIJOS TYRIMAI BEI VERTINIMAS
}

DAKTARO DISERTACIJA

TECHNOLOGIJOS MOKSLAI,

APLINKOS INŽINERIJA IR KRAŠTOTVARKA (04T)

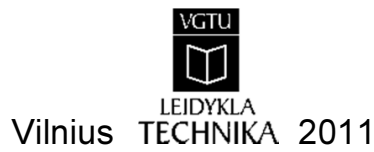


Disertacija rengta 2007-2011 metais Vilniaus Gedimino technikos universitete.

\section{Mokslinis vadovas}

prof. habil. dr. Pranas BALTRĖNAS (Vilniaus Gedimino technikos universitetas, technologijos mokslai, aplinkos inžinerija ir kraštotvarka - 04T).

\section{Konsultantas}

prof. dr. Arvydas LIETUVNINKAS (Tomsko universitetas, aplinkos inžinerija ir kraštotvarka - 04T).

VGTU leidyklos TECHNIKA 1878-M mokslo literatūros knyga http://leidykla.vgtu.lt

ISBN 978-9955-28-859-6

(C) VGTU leidykla TECHNIKA, 2011

(C) Mantas, Pranskevičius, 2011

mantas.pranskevicius@vgtu.lt 
VILNIUS GEDIMINAS TECHNICAL UNIVERSITY

Mantas PRANSKEVIČIUS

RESEARCH AND ASSESSMENT

OF THE TOTAL CARBON CONTENT

AND CARBON DIOXIDE EMISSIONS

FROM SOILS OF DIFFERENT LAND-USE PURPOSE

DOCTORAL DISSERTATION

TECHNOLOGICAL SCIENCES,

ENVIRONMENTAL ENGINEERING (04T)

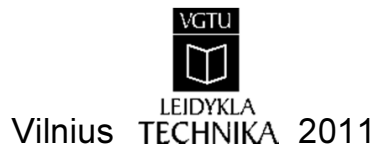


Doctoral dissertation was prepared at Vilnius Gediminas Technical University in 2007-2011.

\section{Scientific Supervisor}

Prof Dr Habil Pranas BALTRĖNAS (Vilnius Gediminas Technical University, Technological Sciences, Environmental Engineering - 04T).

\section{Consultant}

Prof Dr Arvydas LIETUVNINKAS (Tomsk University, Technological Sciences, Environmental Engineering - 04T). 


\section{Reziumè}

Disertacijoje nagrinejjamas bendrosios anglies kiekio dirvožemyje ir iš dirvožemio išskiriamo anglies dioksido dydžio sąryšis. Pagrindiniai tyrimo objektai yra bendrosios anglies kiekis ir anglies dioksido emisijos Neries regioninio parko, Paluknio, Užpalių ir Pailiepio vietovèse.

Darbe sprendžiami uždaviniai: bendrosios anglies kiekio ir anglies dioksido emisijos ịvertinimas skirtingos žeménaudos dirvožemiuose; anglies dioksido išsiskyrimo iš dirvožemio dèsningumai ir sąsaja su bendrosios anglies kiekiu. Trečias uždavinys - modeliavimu įvertinti bendrosios anglies pokyčius ir anglies dioksido emisijos prognozinius kiekius bei priklausomybè nuo klimato rodiklių.

Disertaciją sudaro įvadas, šeši skyriai, rezultatų apibendrinimas, literatūros sąrašas ir autoriaus publikacijų disertacijos tema sąrašas.

Ivadiniame skyriuje aptariama tiriama problema, darbo aktualumas, aprašomas tyrimų objektas, formuluojamas darbo tikslas bei uždaviniai, aprašoma tyrimų metodika, darbo mokslinis naujumas, darbo rezultatų praktinè reikšmé, ginamieji teiginiai. Ivado pabaigoje pristatomos disertacijos tema autoriaus skelbtos publikacijos ir konferencijų pranešimai bei disertacijos struktūra.

Pirmasis skyrius skirtas literatūros analizei. Analizuojama informacija apie dirvodaros energetiką, medžiagų balansa, organinès medžiagos susidarymo ir skaidymosi keliai. Ivertinama, kas nulemia dirvožemio dujų sorbcines savybes ir anglies dioksido emisijos kieki. Aptariami modeliai, kurie taikomi bendrosios anglies kiekiui prognozuoti ir anglies dioksido emisijos pokyčiams ivvertinti. Skyriaus pabaigoje formuluojamos išvados.

Antrajame skyriuje pateikti bendrosios anglies tyrimai, atlikti Neries regioniniame parke, Paluknio, Užpalių ir Pailiepio vietovèse, taip pat atliktų tyrimų metodika ir suformuluotos išvados.

Trečiajame analizuojami bendrosios anglies kiekio $\mathrm{pH}$, sunkiujų metalų ir dirvožemio tyrimai.

Ketvirtajame skyriuje pateikti anglies dioksido išskyrimo iš dirvožemio tyrimai atlikti Neries regioniniame parke.

Penktajame pateikiami bendrosios anglies kiekio ir anglies dioksido emisijos prognoziniai modeliavimo rezultatai, atlikti DNDC modeliu. Šeštame skyriuje pateikiamas išradimo patobulinimas, skirtas dirvožemio ėminiams.

Disertacijos tema yra paskelbti 5 moksliniai straipsniai: du - mokslo žurnale „ISI Web of Science“ duomenų bazèje; vienas - mokslo žurnale, itrauktame i Thomson ISI sąraša; vienas - mokslo žurnale, referuojamame tarptautinėse duomenų bazèse; vienas - tarptautinès ir respublikinès konferencijos medžiagoje. 


\section{Abstract}

The thesis dealt with the single carbon in the soil and carbon dioxide emission level of the soil relationship. The main research objects of Neris Regional Park Paluknio, Užpaliai Pailiepio and location. The primary aim - to create a total carbon and methodologies to assess what amount of carbon are in soils and carbon dioxide emissions amount.

There are few major challenges: the single-carbon and carbon dioxide emissions by different land use soils. Will create on-task formulated in the light of carbon dioxide release from the soil in conjunction with desningumamas bandrosios carbon emissions. The third relates to the modeling, which evaluated changes in single carbon to carbon dioxide emission levels and predictors of dependence on climatic variables.

The thesis consists of an introduction, six chapters, summary and bibliography of publications on the dissertation topic.

Introductory chapter discusses the research problem, the relevance of the description heard shall be the object of research formulates the purpose and objectives, describes the research methodology, scientific novelty, the results of the practical significance of hypotheses. Practical significance of the dissertation sub-published author of publications and conferences, reports and thesis structure.

The first chapter reviews the literature. An overview of information about soil formation energy, materials balance. Assess what determines gas sorption properties of soil and carbon dioxide emissions. Discuss the models used for forecasting the single carbon to carbon dioxide emissions to evaluate the changes. End of this chapter the conclusions are formulated.

The second chapter presents the studies of Neris regional park, Paluknio, and Užpaliai, Pailiepio areas. Available to carry out the research methodology, based on a select sub-objects of research and formulation of conclusions.

The third and fourth section examines the single-carbon, the $\mathrm{pH}$ and carbon dioxide emissions from soil tests. The fifth chapter gives a general carbon and carbon dioxide emissions, forecast the results of a simulation model DNDC. In the sixth chapter present the invention for improvement of soil sampling.

5 articles are published on the dissertation topic: two in ISI Web of Science refereed journal, one in Thomson ISI list, one in reviewed Lithuanian conferences materials, one in not reviewed Lithuanian conferences material. 4 conference reports were made in Lithuania on the topic of dissertation. 


\section{Žymëjimai}

\section{Simboliai}

$-0-\mathrm{CH}_{3}-$ metoksilinè grupé;

A, A1, O1, O2, O3 - dirvožemio genetiniai horizontai;

$\mathrm{A}_{\mathrm{x}}$ - biologinio isisavinimo koeficientas;

$\mathrm{C}: \mathrm{N}$ - anglies ir suminio azoto santykis;

$\mathrm{Ca}^{+2}-$ kalcio jonas;

$\mathrm{CaCl}_{2}-$ kalcio chloridas;

$\mathrm{CaCO}_{3}$ - kalcio karbonatas;

$\mathrm{C}_{\mathrm{an}}$ - analizès $\mathrm{CO}_{2}$ koncentracijos vienetas $\mu$ mols s ${ }^{-1}$;

$\mathrm{CH}_{4}$ - metano dujos;

$\mathrm{C}_{\mathrm{c}}^{\mathrm{i}}$ - cheminio elemento $\boldsymbol{i}$ koncentracija dirvodarinèse uolienose, $\mathrm{mg} / \mathrm{kg}$;

$\mathrm{C}_{\mathrm{j}}^{\mathrm{i}}$ - cheminio elemento $\boldsymbol{i}$ koncentracija dirvožemio horizonte $\boldsymbol{j}, \mathrm{mg} / \mathrm{kg}$;

$\mathrm{C}_{\mathrm{sa}}^{\mathrm{i}}$ - cheminio elemento $\boldsymbol{i}$ koncentracija superakvalinio landšafto dirvožemyje;

$\mathrm{C}_{\text {te }}^{\mathrm{i}}$ - cheminio elemento $\boldsymbol{i}$ koncentracija transeliuvinio landšafto dirvožemyje;

$\mathrm{CO}_{2}$ - anglies dioksidas;

- $\mathrm{COOH}$ - karboksilinè grupe;

$\mathrm{C}_{\text {ref }}$ - standartinis $\mathrm{CO}_{2}$ koncentracijos vienetas $\mu$ mols s ${ }^{-1}$;

Eh - dirvožemio elektrinio laidžio matas; 
$\mathrm{H}_{2} \mathrm{~S}$ - vandenilio sulfido dujos;

$\mathrm{K}^{+}$- kalio jonas;

$\mathrm{K}_{\text {ld }}^{\mathrm{i}}$ - lateraliosios diferenciacijos elemento $\boldsymbol{i}$ koeficientas;

$\mathrm{K}_{\text {rd }}^{\mathrm{i}}$ - radialios diferenciacijos elemento $\boldsymbol{i}$ koeficientas atitinkamame elementariame landšafte;

$\mathrm{K}_{\mathrm{k}}$ - cheminio elemento koncentracijos koeficientas;

$\mathrm{Kp}$ - pasiskirstymo koeficientas;

$l_{x}$ - elemento $x$ kiekis augalų pelenuose;

$\mathrm{Mg}^{+2}$ - magnio jonas;

$\mathrm{Na}^{+}$- natrio jonas;

$\mathrm{NH}_{4}{ }^{+}$- amonio jonas;

$n_{x}$ - elemento $x$ kiekis dirvožemyje;

-OH - hidroksilo grupé;

$\mathrm{pH}$ - vandenilio jonu $\left(\mathrm{H}^{+}\right)$koncentracijos tirpale matas;

$\mathrm{U}$ - srautas i kamerą $\mu \mathrm{mol} \mathrm{s} \mathrm{s}^{-1}$;

$\mathrm{W}_{\text {ref }}$ - dirvožemio drègnis.

\section{Santrumpos}

AAS - atominès absorbcijos spektrofotometras;

AVS - automatinio valdymo sistema;

DLK - didžiausia leistina koncentracija;

DNDC - DeNitrification-DeComposition, denitrifikacijos-skilimo skaitinis modelis;

EKKP - Europos klimato kaitos programa;

ES - Europos Sajunga;

ISO - International Organization for Standardization, Tarptautinè standartų organizacija. 


\section{Sąvokos}

Autonominis landšaftas - geochemiškai dominuojantis vandenskyrų eliuvinis landšaftas, kurio ribose gimsta tęsiantys šlaitais žemyn medžiagų migracijos srautai.

Dirvodarinè uoliena - Žemès plutos sluoksnio uoliena, kurioje per dūlejjimo ir dirvodaros procesus susidare dirvožemis.

Katena - dèsningas elementariuju gamtinių kompleksų (elementariujų geocheminių landšaftų, biogeocenozių) arba dirvožemio tipu šlaituose arba aplink vandens telkinius išsidėstymas. Sin. kaskadinė geocheminių landšaftų sistema.

Landšaftas (kraštovaizdis) - 1) dinaminè gamtinių ir antropogeninių teritorijos komponentų erdvinè sistema; 2) gamtinis geografinis kompleksas, kuriame visi jo pagrindiniai komponentai (geologinis fundamentas, reljefas, klimatas, paviršiniai ir požeminiai vandenys, dirvožemis, augalija ir gyvūnija bei pažemio atmosfera) yra sudètingoje sąveikoje ir bendrame sąlygotume, sudarant evoliucijos sąlygų atžvilgiu vienalytę ir vientisinę sistema; 3) didelè ir sudètinga nepusiausvira ir savaime reguliuojančiosi dinaminè Žemès paviršiaus sistema, kurioje gyvoji medžiaga sąveikauja su lito-, hidro- ir atmosfera.

Lateralioji diferenciacija - cheminių elementu arba komponentu pasiskirstymas horizontaliaja (lateraliaja) kryptimi tarp vienalyčių elementariujų geocheminių landšaftu sudedamujų komponentu, pavyzdžiui, moliuotajame išplautžemių horizonte.

Radialioji diferenciacija - cheminiu elementu arba komponentų pasiskirstymas dirvožemio profilyje vertikaliaja (radialiaja) kryptimi, t. y. tarp jo genetiniu horizontų.

Superakvalinis landšaftas - vietinių reljefo žemumų su negiliu gruntinio vandens slūgsojimu ir aiškia jo ittaka dirvožemiams ir augalijai elementarus landšaftas, kurio dirvožemiuose neretai pasireiškia drègmės perteklius ir susiję su juo deguonies deficitas, glèjiškumas, sulètėją organinių medžiagų skaidymo mikrobiologiniai procesai, i̇durpèjimas. Gruntiniai ir paviršiniai vandenys atgabena tirpių mineralinių ir organinių medžiagu, išplaunamų iš vandenskyrų dirvožemių ir uolienų cheminio dūlèjimo žievès.

Transeliuvinis landšaftas - šlaitų landšaftas, derinantis eliuvinių ir superakvalinių landšaftų požymius. 


\section{Turinys}

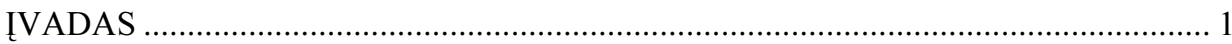

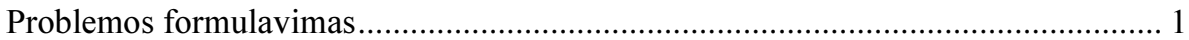

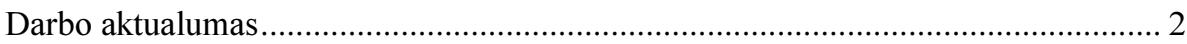

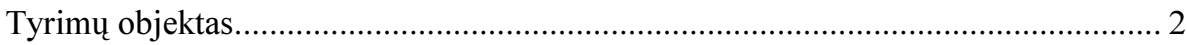

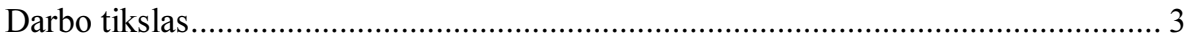

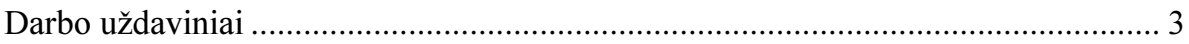

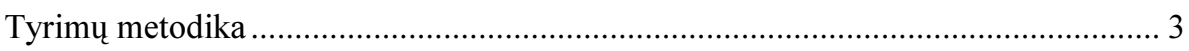

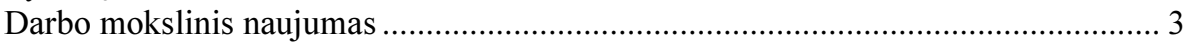

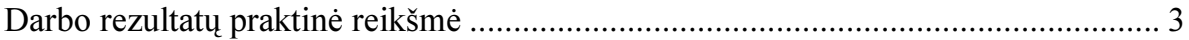

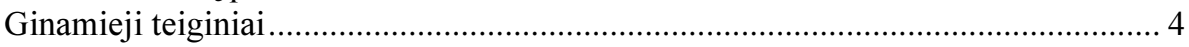

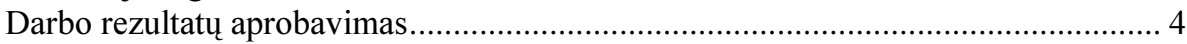

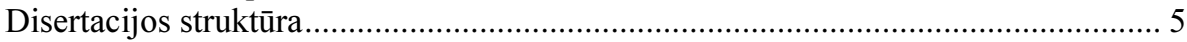

1. DIRVOŽEMIO TYRINĖJIMAI, KLASIFIKAVIMAS IR ANGLIES APYKAITA

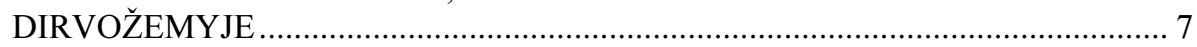

1.1. Dirvožemio tyrinėjimų istorija užsienyje ir Lietuvoje, Lietuvos dirvožemiai..... 7

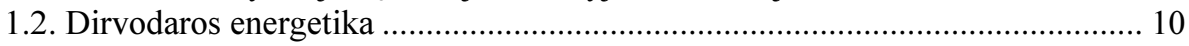

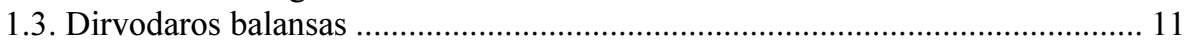

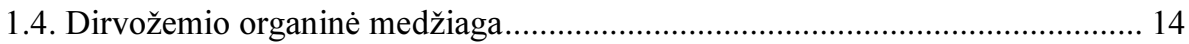

1.5. Dirvožemio oksidacinès-redukcinès savybès ................................................... 19

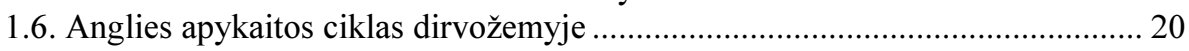

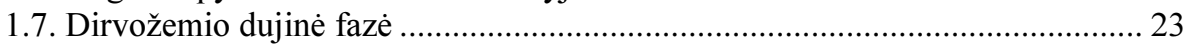


1.8. Mikroorganizmų vaidmuo dirvožemio susidarymui ......................................... 24

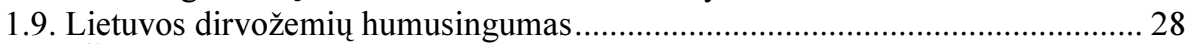

1.10. Žemdirbystès poveikis dirvožemio elementų balansui ir įtaka klimato kaitai. 29

1.11. Miško reikšmẻ bendrosios anglies didinimui dirvožemyje ............................ 33

1.12. Bedrosios anglies kitimo matematiniai modeliai............................................ 36

1.13. Pirmojo skyriaus išvados ir disertacijos uždavinių formulavimas.................... 39

2. SKIRTINGOS PANAUDOS DIRVOŽEMIŲ BENDROSIOS ANGLIES KIEKIO NATŪRINIAI TYRIMAI IR VERTINIMAS

2.1. Dirvožemio bendrosios anglies kiekio tyrimų skirtingos panaudos dirvožemiuose metodika

2.2. Dirvožemio bendrosios anglies kiekio natūrinių sezoninių tyrimų Neries regioniniame parke $2009-2010 \mathrm{~m}$. duomenys ir analize

2.3. Bendrosios anglies kiekio natūrinių tyrimų Užpalių, Paluknio ir Pailiepio

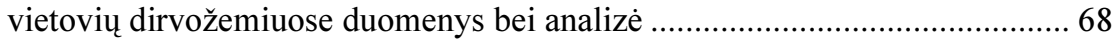

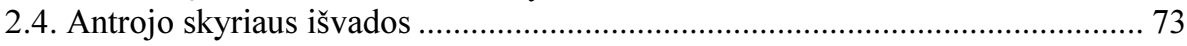

3. DIRVOŽEMIO BENDROSIOS ANGLIES KIEKIO, PH IR SUNKIŲJŲ METALŲ

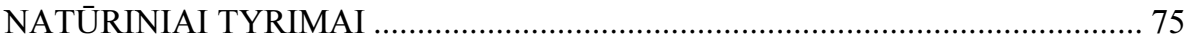

3.1. Dirvožemio pH, sunkiujų metalų nustatymo bei ėminių paèmimo metodika.... 76

3.2. Dirvožemio bendrosios anglies kiekio, $\mathrm{pH}$ ir sunkiujų metalų natūriniai tyrimai Neries regioniniame parke duomenys ir analizè ......................................... 78

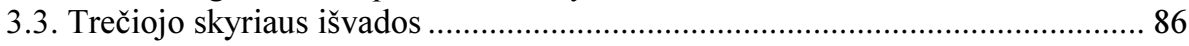

4. ANGLIES DIOKSIDO EMISIJU巳 IŠSISKYRIMO IŠ NERIES REGIONINIO PARKO DIRVOŽEMIŲ NATŪRINIAI TYRIMAI ............................................ 87

4.1. Anglies dioksido emisijos tyrimo metodika .................................................. 87

4.2. Anglies dioksido emisijų natūriniai tyrimai skirtingos panaudos dirvožemiuose Neries regioniniame parke duomenys ir analizè ............................................ 91

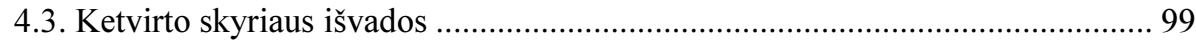

5. DIRVOŽEMIO BENDROSIOS ANGLIES KIEKIO KAITOS IR ANGLIES DIOKSIDO EMISIJŲ IŠ SKIRTINGOS PANAUDOS DIRVOŽEMIŲ MODELIAVIMAS.

5.1. Dirvožemio bendrosios anglies kiekio kitimo, bei $\mathrm{CO}_{2}$ emisijų modeliavimas DNDC modeliu

5.2. Bendrosios anglies kiekio kitimo ir anglies dioksido emisijų modeliavimo duomenys ir analizè

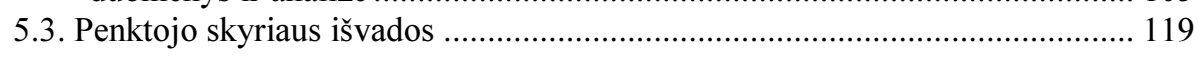

6. INŽINERINIAI TECHNINIAI SPRENDIMAI................................................. 121

6.1. Dirvožemio ėminių paėmimo metodika naudojant dirvožemio grąžtą............ 122

6.2. Dirvožemio ėminių paėmimo grąžto techninis aprašymas ............................... 122

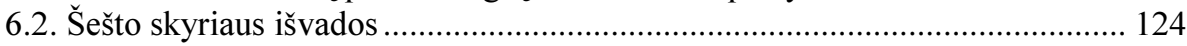


BENDROSIOS IŠVADOS

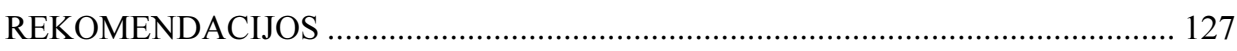

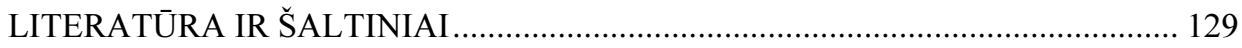

AUTORIAUS PUBLIKACIJOS DISERTACIJOS TEMA ………………………..... 139 


\section{Contents}

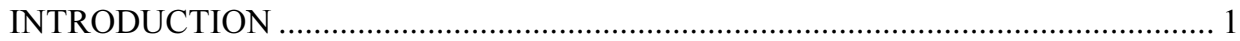

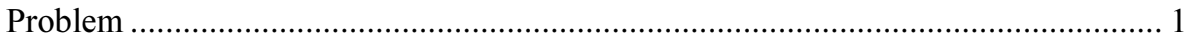

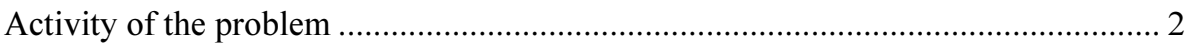

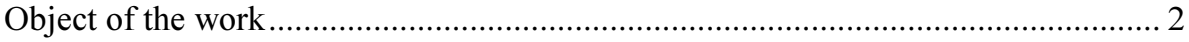

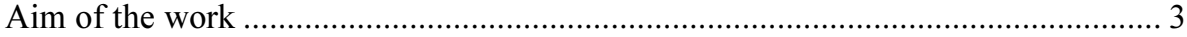

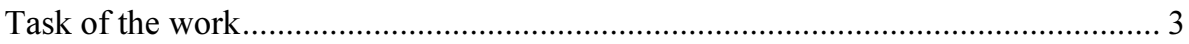

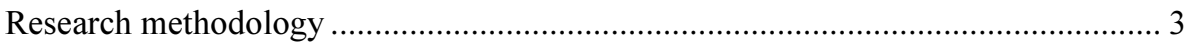

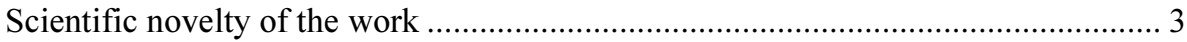

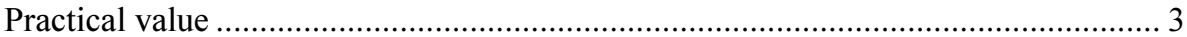

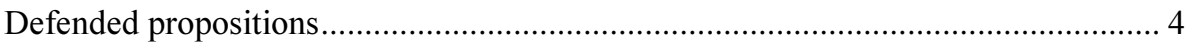

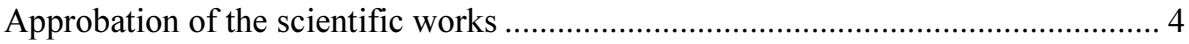

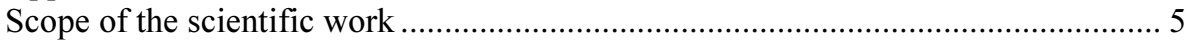

\section{SOIL INVESTIGATIONS, CLASSIFICATION AND CARBON}

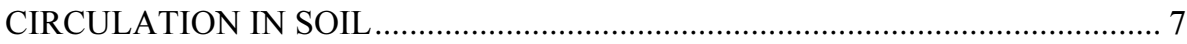

1.1. Soil Exploration History abroad and in Lithuania, the Lithuanian soil ............... 7

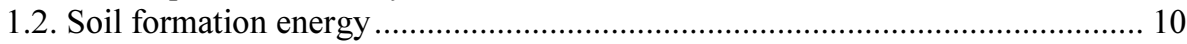

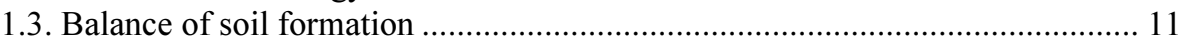

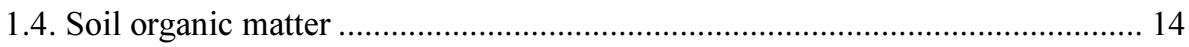

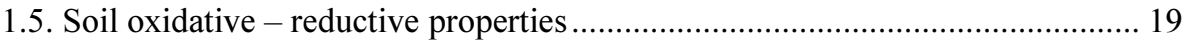

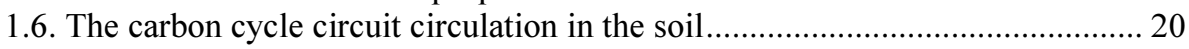

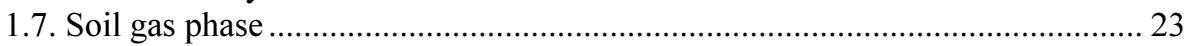




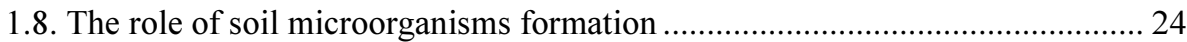

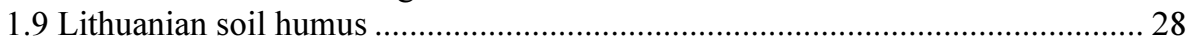

1.10. Farming effect on soil elements in the balance of power and climate change. 29

1.11. The general importance of forests increase soil carbon................................... 33

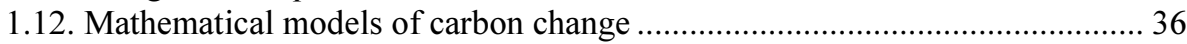

1.13. Conclutions for Chapter 1 and formulating tasks for the dissertation ............. 39

2. NATURAL INVESTIGATIONS AND ASSESSMENT OF THE TOTAL

CARBON CONTENT IN SOILS OF DIFFERENT LAND-USE PURPOSE .......... 41

2.1. Soil investigation total carbon in soils of different lending methodologies ...... 42

2.2. Soil total carbon quantity seasonal studies of Neris Regional Park 2009-2010

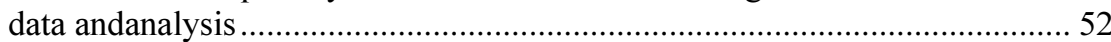

2.3. Total soil total carbon in situ studies of different areas Pailiepio Užpaliai and

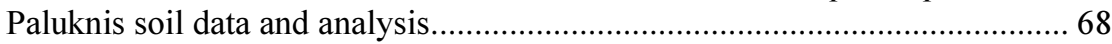

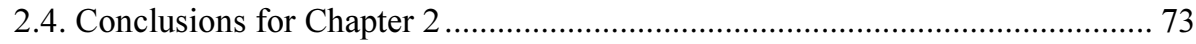

3. TOTAL SOIL CARBON CONTENT, PH AND HEAVY METALS IN SITU STUDIES OF THE NERIS REGIONAL PARK AND THE DATA ANALYSIS .. 75

3.1. Soil $\mathrm{pH}$, heavy metals investigation and sampling methodology .................... 76

3.2. Total soil carbon content and $\mathrm{pH}$, heavy metals in situ investigation of the Neris Regional Park the data and analysis.......................................... 78

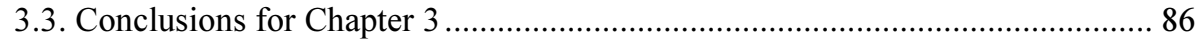

4. NATURAL INVESTIGATIONS OF CARBON DIOXIDE EMISSIONS FROM

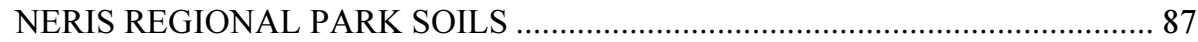

4.1. Carbon dioxide emissions investigation methodology ................................... 87

4.2. Carbon dioxide emissions in situ investigation of different land use soils in Neris Regional Park the data and analysis .................................................... 91

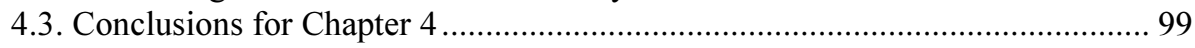

5. TOTAL CARBON AND CARBON DIOXIDE EMISSIONS MODELING

CHANGE IN SOILS OF DIFFERENT LAND-USE PURPOSE ........................... 101

5.1. Total soil carbon and $\mathrm{CO}_{2}$ emissions simulation using model DNDC ............ 102

5.2. Total carbon and carbon dioxide emissions modeling data and analysis ........ 105

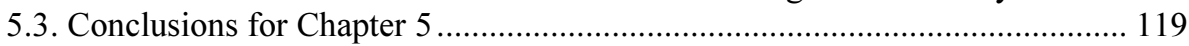

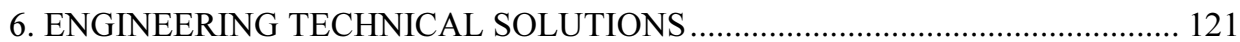

6.1. Soil sampling using a soil sampling drill technique ..................................... 122

6.2. Soil sampling drill technical description ..................................................... 122

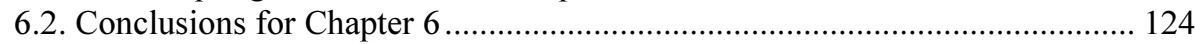

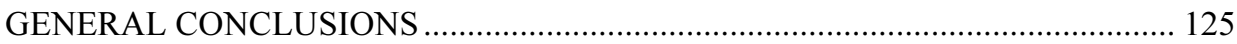

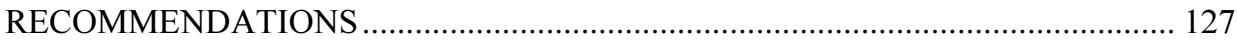


REFERENCES 129

AUTHOR PUBLICATIONS ON THE TOPIC OF DISSERTATION. 139 



\section{Ivadas}

\section{Problemos formulavimas}

Dirvožemyje yra didžiausios anglies atsargos pasaulyje (1500 gigatonų). Jo atliekamos funkcijos tiesiogiai įtakoją žmogų ir gyvają gamtą. Todèl šias funkcijas reikia saugoti dèl jų socialinès bei ekonominès svarbos, ir dèl reikšmès aplinkai. Tačiau dèl žmogaus veiklos dirvožemiai degraduoja, o tai itakoja anglies ir anglies dioksido emisijų pokyčius.

Iš visų klimato atšilimą skatinančių dujų net $57 \%$ priskiriami $\mathrm{CO}_{2}$ dujoms. Apie $20 \%$ viso $\mathrm{CO}_{2}$ kiekio, i atmosferą išskiria dirvožemiai, todèl dirvožemiai daro nemažą itaką $\mathrm{CO}_{2}$ balansui. Apskaičiuota, kad intensyvaus žemės naudojimo laikotarpiu (tarp 1850 ir 1998 metų) dirvožemio organinès medžiagos nuostolių balanse vieną trečdali $(26 \pm 9 \mathrm{Gt})$ sudarè nuostoliai dèl dirvožemio erozijos ir apie du trečdalius $(52 \pm 8 \mathrm{Gt})$ dèl mineralizacijos. Apskaičiuota, kad anglies (elemento) nuostoliai iš Europos dirbamų dirvų siekia 78 Mt per metus. Ryškiausi pokyčiai pasireškia lengvos granuliometrinès sudèties dirvožemiuose ir nusausinamose pelkèse.

Ivertinus anglies dioksido emisija pasauliniu mastu ir apibendrinus tyrimus atliktus įvairiose šalyse, matyti, kad dar labai trūksta trumpalaikių (nuo kelių valandų iki kelių dienų ir (ar) mènesių) bei ilgalaikių duomenų apie konkrečios 
šalies anglies dioksido emisijas. Nei trumpalaikių, nei ilgalaikių tyrimų duomenų apie $\mathrm{CO}_{2}$ emisijos mąsta, Lietuvoje taip pat nèra.

Būtina vertinti anglies kiekius dirvožemyje, siekiant laiku užkirsti kelią dirvožemio degradacijai, išsaugant dirvožemių derlingumą ir užtikrinti biologinę ivairovę bei palankias gyvenimo sąlygas. Ivertinus dirvožemyje anglies kiekius ir dèl mineralizacijos procesų išsiskirianti anglies dioksido emisijų dydį i̇manoma pritaikyti priemones, mažinančias arba užkertančias tolesnei dirvožemio degradacijai.

\section{Darbo aktualumas}

Kioto protokole pabrèžiama, kad dirvožemyje yra pagrindinès anglies atsargos, kurias reikia apsaugoti ir kiek imanoma didinti. Atliekami tyrimai vertinant tradicinę žemès dirbimo sistemą i neariamają ir kaip tai įtakoja anglies kieki dirvožemyje. Prieš 10 metų Dotnuvoje pradèti vieni iš pirmujų Lietuvoje lauko bandymai, siekiant kompleksiškai ištirti skirtingas žemès dirbimo sistemas. Jų metu nustatyta dirvožemio degradavimo grésmè. Tačiau, tokie tyrimai atliekami tik parengtuose bandymo laukuose. Apibendrintų duomenų apie $\mathrm{CO}_{2}$ emisiją Lietuvos žemès ūkio ir miškų sektoriuje taip pat trūksta. Pasaulyje vis dažniau dėmesys krypsta į esamą dirvožemių būklę, siekiant ịvertinti jų itaką klimato kaitai ir atvirkščiai.

Lietuvoje šia aktualią tematiką nagrinejja Lietuvos agrarinių ir miškų mokslo centro mokslininkai. Analizuojamas humuso kiekis dirvožemyje, nustatomi suminès anglies kiekiai ir anglies dioksido išskyrimo iš dirvožemio, arba emisijos, dydžiai (S. Marcinkonis, D. Feizienè, V. Feiza, V. Povilaitis, G. Kadžienè). Taip pat, atliekami miško paklotès suminès anglies tyrimai, nagrinejjami i dirvožemị patenkantys anglies srautai ir anglies dioksido išsiskyrimas i atmosferą (K. Armolaitis, P. Žemaitis).

\section{Tyrimų objektas}

Darbo tyrimu objektas - bendrosios anglies kiekio ir anglies dioksido emisijos Neries regioninio parko, Paluknio, Užpalių ir Pailiepio vietovių skirtingos panaudos dirvožemiuose. 


\section{Darbo tikslas}

Ivertinti bendrosios anglies kiekị ir anglies dioksido emisijas skirtingos žemènaudos dirvožemiuose.

\section{Darbo uždaviniai}

1. Atlikti bendrosios anglies kiekio ir anglies dioksido emisijos skirtingos žemènaudos dirvožemiuose tyrimus.

2. Ivertinti anglies dioksido emisijos iš dirvožemio dèsningumus ir sąsają su bendrosios anglies kiekiu.

3. Modeliuojant ivvertinti bendrosios anglies kiekio pokyčius ir anglies dioksido emisijos prognozes, taip pat priklausomybę nuo klimato rodiklių.

\section{Tyrimų metodika}

Darbe taikytos autoriaus patobulintos dirvožemio ėminių paèmimo ir bendrosios anglies kiekio tyrimo metodikos. Taip pat taikytos ISO standartais paremtos sunkiujų metalų ir $\mathrm{pH}$ nustatymo metodikos. Autorius pritaikè anglies dioksido emisijos tyrimų metodiką. Dirvožemio bendrosios anglies kiekio ir anglies dioksido emisijos dinamika analizuota skaitinio modeliavimo programa DNDC.

\section{Darbo mokslinis naujumas}

Kompleksiniai eksperimentiniai dirvožemio bendrosios anglies kiekio bei anglies dioksido emisijos tyrimai ir kiekio pokyčių vertinimas modeliuojant.

\section{Darbo rezultatų praktinė reikšmė}

Darbe sukaupta medžiaga gali būti taikoma tolesniems dirvožemio bendrosios anglies tyrimams. Sukaupti duomenys gali būti taikomi teritorinei analizei ịvertinti anglies dioksido emisijas bei modeliavimui. Taip pat sukaupti duomenys gali būti panaudoti anglies ir anglies dioksido emisijai vertinti skirtingos panaudos dirvožemiuose. Modeliavimo rezultatai gali būti taikomi Lietuvos teritorinius dirvožemius vertinant pagal bendrają angli ir anglies dioksidą. 


\section{Ginamieji teiginiai}

1. Pasirinktų anglies tyrimams teritorijų dirvožemiai pagal sunkiujų metalų koncentracijų lygi artimi neužterštų (foninių) teritorijų dirvožemiams.

2. Didžiausi vidutiniai bendrosios anglies kiekiai ištirti superakvalinio landšafto pievų dirvožemiuose (iki 3,02\%), autonominio landšafto pievos dirvožemyje (iki 1,37\%), miško dirvožemio superakvaliniame dirvožemyje iki 4,54\%, autonominio landšafto dirvožemyje (iki 1,39\%), o mažiausi ariamame dirvožemyje (iki 2,25\%).

3. Natūriniais tyrimais, kad didžiausia anglies emisija pasižymi ariamieji dirvožemiai (iki $0,263 \mathrm{~g} \mathrm{CO}_{2} \mathrm{~m}^{-2} \mathrm{~h}^{-1}$ ) mažesne pievos (iki $0,149 \mathrm{~g} \mathrm{CO}_{2} \mathrm{~m}^{-2} \mathrm{~h}^{-1}$ ) ir miško (iki $0,139 \mathrm{~g} \mathrm{CO}_{2} \mathrm{~m}^{-2} \mathrm{~h}^{-1}$ ). Anglies dioksido emisija dirvožemiuose patikimai tiesiogiai koreliuoja su aplinkos oro temperatūra $(r=0,67)$ ir jo santykine drègme $(\mathrm{r}=0,51)$ bei dirvožemio drègnumu $(\mathrm{r}=0,54)$.

4. Modelio DNDC duomenimis didžiausia anglies dioksido emisija Lietuvos klimato sąlygomis pasižymi miško dirvožemiai $\left(3,18 \mathrm{kgCO}_{2} / \mathrm{m}^{2}\right.$ per para), pievų $\left(2,83 \mathrm{kgCO}_{2} / \mathrm{m}^{2}\right.$ per para), mažiausia - ariamieji dirvožemiai $(2,11$ $\mathrm{kgCO}_{2} / \mathrm{m}^{2}$ per para), per metus daugiausiai anglies prarandama ariamame dirvožemyje (per pirmus metus $830 \mathrm{kgC} / \mathrm{ha}$, po 10 metu $452 \mathrm{kgC} / \mathrm{ha}$ ), pievų dirvožemyje (per pirmus metus $740 \mathrm{kgC} / \mathrm{ha}$, po 10 metų $542 \mathrm{kgC} / \mathrm{ha}$ ), o miško dirvožemiuose padidès (per pirmus metus $937 \mathrm{kgC} / \mathrm{ha}$, po 10 metu 565 $\mathrm{kgC} / \mathrm{ha})$.

\section{Darbo rezultatu aprobavimas}

Disertacijos tema yra paskelbti 5 moksliniai straipsniai: vienas - mokslo žurnale, itrauktame i Thomson ISI sąrašą; du - mokslo žurnale „ISI Web of Science“" (citavimo rodiklis 1,508 ) duomenų bazeje; vienas - mokslo žurnale, referuojamame tarptautinèse duomenų bazėse; vienas - tarptautinès ir respublikinès konferencijos medžiagoje.

Disertacijoje atliktų tyrimų rezultatai buvo paskelbti keturiose mokslinėse konferencijose Lietuvoje ir pristatyti COST 639 programos „Greenhouse-gas budget of soils under changing climate and land use (BurnOut)" valdymo komiteto posedyje. 


\section{Disertacijos struktūra}

Disertaciją sudaro 6 skyriai, bendrosios išvados ir rekomendacijos, literatūros ir autoriaus publikacijos sąrašas. Bendra disertacijos apimtis 157 lapai, 74 paveikslai, 5 lentelès ir 6 formulès. 



\section{1}

\section{Dirvožemio tyrinèjimai, klasifikavimas ir anglies apytaka dirvožemyje}

\subsection{Dirvožemio tyrinèjimų istorija užsienyje ir Lietuvoje, Lietuvos dirvožemiai}

Šiuolaikiniu gamtotyros supratimu, dirvožemis - ypatinga gamtinè biosferos formacija, ypatingas gamtinis kūnas, susidaręs Žemès plutos paviršiuje, veikiant šiems veiksniams: klimatui, dirvodarinei uolienai, reljefui, augalams ir gyviems organizmams šalies vystymosi laikotarpiu (Bužas A. 1966). Išskirti prioritetinius dirvodaros veiksnius labai sudėtinga, nes jie tarpusavyje glaudžiai susiję. Skirtingų veiksmų visuma suformuoja skirtingus dirvožemius .

Dirvožemių aprašymų yra jau antikos (Teofrasto, Katono) darbuose. Moksliškai tirti dirvožemius pradèta XVIII amžiuje. XVIII pabaigoje ir XIX a. pradžioje dirvodaros raidą ypač paspartino A. Tèro (Thear) ir J. Lybigo (Liebig) darbai (humanistinè augalų mitybos ir augalų mineralinès mitybos teorijos). V. Dokučiajevas monografijoje „Rusijos juodžemis“ (1883) suformulavo genetinès dirvotyros svarbiausia teiginị: dirvožemis yra savarankiškas istorinis gamtos kūnas, dèl gyvujų organizmų poveikio susidaręs paviršiniuose uolienos sluoks- 
niuose. Dokučiajevas taip pat geografinès dirvodaros krypties pradininkas (Adams 1990). Rusijoje agronomine dirvotyros kryptis atsirado XIX a. pabaigoje (pradininkas P. Kostyčevas; ištyrė augalų ir mikroorganizmų itaką dirvožemių raidai, derlingumui), XX a. pradžioje - chemijos kryptis (K. Gedroicas; sukūrè dirvožemių koloidų chemijos pagrindus ir tuo padejo geriau suprasti dirvodaros procesu esmę). XX a. 3 dešitmetyje atsirado dirvodaros biocheminė kryptis (V. Vernadskis; tyré, kaip dirvodarą veikia gyvieji organizmai). XX a. 4 dešimtmetyje atsirado naujos dirvotyros šakos (dirvožemio chemija, fizika, mineralogija, mikrobiologija). Po to susikūrè pasaulyje garsios JAV, Vokietijos, Prancūzijos dirvožemininkų mokyklos.

Lietuvoje dirvotyra atsirado $1819 \mathrm{~m}$., kai Vilniaus universitete buvo įsteigta ž. ū. mokslų katedra, kurios profesorius A. Očapovskis tyrė dirvožemių susidaryma, jų granuliometrinę sudèti, suklasifikavo krašto dirvožemius pagal jų tin-

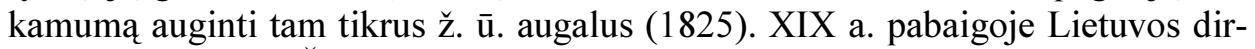
vožemius tyrė V. Časlavskis, XX a. pr. - S. Miklaševskis, 1922-1940 Kauno universitete, Ž. ū. akademijoje - J. Tonkūnas. 1930 m. V. Ruokis suklasifikavo Lietuvos dirvožemius pagal drègmès režima, reljefa, granuliometrinę sudèti, 1936 m. parengè Pietų Lietuvos dirvožemių žemélapi. $1930 \mathrm{~m}$. išleista jo knyga „Dirvožemio mokslas“, 1933 m. - „Lietuvos dirvožemių reakcija“, 1939 m. „Pietų Lietuvos dirvožemiai“. Bandymų stočių dirvožemius tyre B. Baginskas ir M. Žemaitis (Baginskas 1984).

Po II pasaulinio karo Lietuvoje dirvožemius tirti ir kartografuoti pradejo Ž. ù. institutas (ikurtas 1946 m.). 1952-1956 tą darbą dirbo Žemdirbystès ir dirvožemio institutas, nuo $1956 \mathrm{~m}$. Žemdirbystès institutas, jo Vokès filialas, bandymų stotys, nuo $1961 \mathrm{~m}$. ir Žemètvarkos institutas. Dirvožemius tiria ir šalies universitetų dirvožemininkai. 1946-1953 buvo parengta Lietuvos dirvožemių genetinė klasifikacija. 1951 m. išleistas pirmasis Lietuvos dirvožemių žemėlapis. $1961 \mathrm{~m}$. baigta rengti Lietuvos dirvožemių bonitavimo metodika. Iki $1970 \mathrm{~m}$. parengtas Lietuvos žemès kadastras, iki 1973 sudaryti visų Lietuvos ūkių dirvožemių žemèlapiai, parengtos dirvų kalkinimo ir jų maisto medžiagų kartogramos. Lietuvos dirvožemiai tiriami dar ir Vandens ūkio institute (melioracijos ir dirvožemių erozijos stabdymo problemos). Miškų institutas parengè dirvožemių tyrimo, kartografavimo ir bonitavimo metodiką, sudare miškų dirvožemių ir miško augaviečių klasifikacijas (Buivydaitè 2001, 1990).

Lietuvos teritorijos paviršių, išskyrus nedideli pietinès dalies plota, suformavo paskutiniojo Valdajaus apledejjimo periodo ledynų nuogulos, kurias paliko ištirpęs ledynas maždaug prieš 12-20 tūkst. metų. Pagal reljefo genetinį tipą Lietuvoje apie 30\% užima dugniniai ledyno dariniai, $27 \%$ - ledyno pakraščio dariniai, 23\% - limnoglacialiniai dariniai, 11\% - fliuvialiniai dariniai, 7\% - fliuvioglacialiniai dariniai, o likusią dali - eoliniai, marininiai, organogeniniai, karstiniai ir eroziniai dariniai (Griciūtè 1979). 
Iš skirtingų dirvodarinių uolienų, veikiant ịvairiems veiksniams, susiformavo labai nevienodi savo savybėmis dirvožemiai. Dabartinès dirvožemių dangos bruožai atsirado subatlantinių laikotarpiu, išaugus mišriujų miškų bendrijoms (Motuzas 1996, Jankauskas 2006, 1996). Nuo to laiko reiškiasi visi pagrindiniai dirvodaros procesai: jaurejjimas, velènejimas ir pelkejjimas, kurių sąveika arba vieno kurio proceso vyravimas lèmé dirvožemio dangos ivvairumą. Subatiantiniu laikotarpiu beveik visą Lietuvos teritoriją dengè miškai (Šleinys 1994). Todèl dirvožemių pagrindines savybes suformavo dèl spygliuočių augalijos poveikio vykę jaurejjimo procesai (Lietuvos dirvožemiai ... 2001). Iki 1999 metų Lietuvos teritorijos dirvožemiai buvo skirstomi i tokias dirvožemių grupes: jaurinius, velèninius karbonatinius, velèninius glèjinius, jaurinius pelkinius, pelkinius, aliuvinius, eliuvinius, nuardytus (Lietuvos dirvožemių... 1998).

Šiuo metu nauja Lietuvos dirvožemių klasifikacija dar tobulinama, bet pagrindinès vyraujančių Lietuvoje dirvožemių grupès jau nustatytos. Lietuvos teritorijoje yra. tokie dirvožemiai: balkšvažemiai (Albeluvisols), durpžemiai (Histosols), išplautžemiai (Luvisols), jauražemiai (Podzols), kalkžemiai (Lepto-sols), palvažemiai (Planosols), pradžiažemiai (Regosols), rudžemiai (Cambisols), salpžemiai (Fluvisols), smèlžemiai (Arenosols), šlynžemiai (Gleysols), trąšažemiai (Anthrosol) (Lietuvos dirvožemiai... 2001).

\subsection{Dirvodaros energetika}

Svarbiausias ir praktiškai vienintelis patenkančios i dirvožemi energijos šaltinis yra Saulès radiacija. Visas Žemès paviršius per metus gauna iš Saulès $21 \cdot 10^{20} \mathrm{~J}$ šilumos. Daugiausia šios energijos sunaudojama klimato veiksniams ir vandenynų srovėms suformuoti. Autotrofiniai žalieji augalai pasisavina tik nuo 0,5 iki 5 proc. Saulès energijos (Motuzas 1996).

Vykstant natūraliai dirvodarai, Saulès energijos sunaudojimą iš esmès lemia radiacijos balansas, drékinimo koeficientas (kritulių kiekio ir išgaravimo nuo atviro vandens santykis) ir ekosistemos biologinis aktyvumas (1 lentelè).

Žemès ūkio naudmenų dirvožemiuose ši dydi taip pat lemia dirvožemio šilumos imlumas, faktinis drègnumas (ypač drékinant) ir žemès ūkio augalų derlingumas. Taigi išryškejja energetinių ir ekonominių derlingumo parametrų tam tikri ryšiai. Tai lemia ta aplinkybè, kad dirvožemio energetinis balansas priklauso ne tik nuo Saulès energijos patekimo, transformavimosi ir grąžinimo ị atmosferą intensyvumo, bet ir nuo biocheminès medžiagų akumuliacijos ir migracijos pobūdžio. Žinoma, kad visoje Žemès sausumos biomaseje sukaupta $6,15 \cdot 10^{19} \mathrm{~kJ}$, o jos humusinio sluoksnio ,plèvelejje“ $-5,33 \cdot 10^{19} \mathrm{~kJ}$ energetiniu atsargų. Vykstant dirvodarai ar dūlèjimui, taip pat esti nemažai energetinių pokyčių ir dirvožemio mineralineje dalyje. Pirmiausia jie sietini su pirminių elementų ardymu 
bei antrinių elementų susidarymu ir pirminių kalnų uolienų dalelių sorbuojamojo paviršiaus didejjimu (Šleinys 1994).

Bendrą energijos kieki dirvožemyje lemia energijos atsargos, sukauptos pagrindiniuose jo komponentuose: organinèse ir mineralinèse medžiagose, dirvožemio tirpale, dirvožemio ore ir gyvojoje fazejje. Kadangi drègmès ir oro kiekis, taip pat ir organinès medžiagos masè elementai dinamiški rodikliai, todèl dirvožemio energetinį režimą reikia sieti su konkrečiais vegetacijos tarpsniais.

1.1 lentelè. Energijos atsargos humuse ir augaluose, $\mathrm{kJ} \mathrm{cm}^{-2}$ (Motuzas 1996)

Table 1.1. The energy reserves of humus and plants, $\mathrm{kJ} \mathrm{cm}^{-2}$ (Motuzas 1996)

\begin{tabular}{|l|c|c|c|}
\hline \multicolumn{1}{|c|}{ Kraštovaizdžio zona, dirvožemiai } & $\begin{array}{c}\text { Humusi- } \\
\text { nis } \\
\text { sluoksnis }\end{array}$ & $\begin{array}{c}\text { Dirvožemio } \\
\text { sluoksnis } \\
\text { (0-100) }\end{array}$ & $\begin{array}{c}\text { Sausu- } \\
\text { mos } \\
\text { augalai }\end{array}$ \\
\hline Dykuma, juosvažemiai (Phaeozems) & 4920 & 13940 & 2870 \\
\hline Sausoji stepé, kaštonžemiai (Kastanozems) & 11890 & 35260 & 6150 \\
\hline Stepé, juodžemiai (Chernozems) & 29520 & 54300 & 10250 \\
\hline Pietinè taiga, išplautžemiai (Luvisols) & 15990 & 22140 & 58425 \\
\hline Taigos plačialapiai miškai, rudžemiai (Cambisols) & 22140 & 48380 & - \\
\hline paatogražiu miškai, geltonžemiai Lixisols) & 19270 & 39770 & 292125 \\
\hline $\begin{array}{l}\text { Kserofitiniai paatogražių miškai, geležaliuminže- } \\
\text { miai (Ferralsols) }\end{array}$ & 26240 & 62730 & - \\
\hline
\end{tabular}

Energetinis dirvodaros balansas susideda iš energijos: 1) sunaudotos fizikiniam dūlejjimui; 2) sunaudotos mineralams ardyti vykstant cheminiam dūlèjimui (nuo 2 iki $62 \mathrm{~J} \mathrm{~cm}^{-2}$ per metus); 3) sunaudotos biomasei produkuoti (nuo $103 \mathrm{iki}$ $800 \mathrm{~J} \mathrm{~cm}^{-2}$ per metus ivairiose zonose), kurios tik maža dalis akumuliuojasi humuse; 4) sąnaudu drègmei išgarinti (nuo $12300 \mathrm{~J} \mathrm{~cm}^{-2}$ tundrose iki $246000 \mathrm{~J}$ $\mathrm{cm}^{-2}$ per metus tropikuose); 5) nuostolių dèl mechaninès smulkžemio daleliu ir druskų migracijos; 6) sunaudotos vykstant šilumos kaitos procesui sistemoje dirvožemis - atmosfera (Motuzas 1996, Орлов 1990).

Taigi natūraliomis sąlygomis mažiausiai energijos dirvodarai sunaudojama tundroje (8-20 $\mathrm{kJ} \mathrm{cm}^{-2}$ per metus) ir dykumoje, šiek tiek daugiau - vidutinių platumų zonoje (40-60 $\mathrm{kJ} \mathrm{cm}^{-2}$ per metus) ir daugiausia - drègnuose tropikuose (246-287 kJ cm ${ }^{-2}$ per metus) (Motuzas 1996, Орлов 1990).

Antropogeniniuose šių landšaftinių zonų dirvožemių variantuose šie skaičiai dèl žemdirbystès intensyvumo, suprantama, gali būti visiškai. 
Tam tikra prasme i dirvodara galima žiūrèti kaip i medžiagų išplovimo ir akumuliacijos (santykinès ir absoliučiosios) santykị dirvodaros paveiktame litosferos sluoksnyje.

Absoliučioji medžiagų akumuliacijas vykstant dirvodarai - tai dirvodarinès uolienos gausinimas junginiais išs: atmosferos ir hidrosferos bei šių junginių kaupimasis besiformuojančiame dirvožemyje. Taip dirvožemiuose kaupiasi anglis (fotosintezè - biomasès sintezè - mirimas - suirimas - humifikacija - humuso kaupimasis), azotas (azoto fiksavimas - organizmuc pasisavinimas - biomasès mirimas - nitrifikacija - amonifikacija), lengvai tirpios druskos - gipsas, karbonatai, geležies junginiai, silicis (iš gruntinio vandens). Absoliučiajai medžiagų akumuliacijai turi itakos ir dujinio azoto, anglies, sieros režimas (Motuzas 1996). Nustatyta, kad augalų vegetacijos metu nuo dirvožemio paviršiaus išgaruoja ženklus (5-30 kg ha ${ }^{-1}$ per valanda, arba $600-700 \mathrm{~kg} \mathrm{ha}^{-1}$ per para) $\mathrm{CO}_{2}$ kiekis. Trečdali šio kiekio gamina augalų šaknys, o likusiają - mikroorganizmai ir mezofauna. I atmosferą išsiskiria ne daugiau nei 10 proc. Dirvožemyje esančios angliarūgštès kiekio. Likusioji jos dalis kaupiasi dirvožemio porose, ištirpsta dirvožemio tirpale, dalyvauja karbonatinių medžiagų sisidarymo ir tirpimo reakcijose (Feizienė 2009).

\subsection{Dirvodaros balansas}

Dirvodaros procese išskiriami šie 4 medžiagu ir energijos balanso komponentai: 1) medžiagų ir energijos prietaka į dirvožemi; 2) medžiagų ir energijos pokyčiai dirvožemyje; 3) medžiagų ir energijos persiskirstymas dirvožemyje; 4) medžiagų ir energijos pasišalinimas iš dirvožemio. Visos šios balanso dalys glaudžiausiai tarpusavyje susijusios ir veikia viena kitą. Šie 4 komponentai lemia ir bendrą dirvožemio susidarymo krypti, ir dirvožemio profilio sandara, sudetį ir savybes. Konkrečiai šis kompleksas išreiškiamas kaip dirvodaros medžiagų balansas medžiagu prietakos i dirvožemị ir jų netekimo per tam tikrą laikotarpi santykis. Iš jo pirmiausia ir sprendžiama apie dirvodaros pobūdžio pokyčius. Pavyzdžiui, pažemejjus gruntiniams vandenims ir išgarinamajam drègmès režimui pasikeitus i išplaunamaji (arba periodiškai išplaunamaji) bei prasidejus druskų išplovimui iš įdruskejjusiu dirvožemių, teigiamas druskų balansas tampa neigiamas. Pagal laikotarpio trukmę išskirtos šios medžiagų balanso formos: a) trukmę, prilygstančią geologiniam amžiui; b) periodini (cikliška), paprastai trunkanti 11-25 metų ir, matyt, lemiamą Saulès aktyvumo periodiškumo ciklų; c) teritorijos metinio hidrologinio balanso trukmès laikotarpi; d) drèkinamos žemdirbystès rajonuose išskiriamus trumpalaikius tarp dviejų artimiausių lietinimų hidrologinio balanso periodus (Motuzas 1996, Janušienè 1994, Vaišvila 1999). 
Kokybiškai skiriasi organinių medžiagų, azoto, drègmès, mineralinių elementų, tarp jų ir tirpių druskų balansas. Sakysime, organinių medžiagų ir azoto balansą daugiau lemia gyvų organizmų aktyvumas, o ne abiotiniai srautai (atmosferos krituliai, paviršinis nuotèkis). Drègmès režimo ir mineralinių elementų balansui vienodai reikšmingi tiek biotiniai, tiek abiotiniai (visgi pastarieji dažniausiai lemia drègmès balanso pobūdị) veiksniai (Danilevičius 1977).

Dirvožemio medžiagų balanso pajamų dali sudaro: 1) anglis, azotas ir pelenų elementai, patenkantys su nuokritomis ir apmirusiomis augalų ir gyvūnų liekanomis; 2) tų pačių elementų kiekis, patenkantis iš šaknų išskyrų ir per augalų lajų ardą prasisunkusių kritulių; 3) azoto kiekis, mikroorganizmų fiksuotas iš atmosferos; 4) medžiagos, patenkančios su krituliais; 5) medžiagos, patenkančios su atmosferos dulkèmis; 6) medžiagos, patenkančios su paviršinio nuotèkio kietomis dalelėmis; 7) medžiagos, susikristalizavusios iš paviršinio nuotekio skystosios fazės; 8) medžiagų prietaka dèl šoninès požeminès tèkmès; 9) medžiagų kiekis, kapiliarais pakilęs iš gruntinių vandenų horizonto; 10) medžiagos, patenkančios su trąšomis, meliorantais bei drèkinimo vandeniu (Jankauskas 2006, 2003, Vaišvila 1999).

Dirvožemio medžiagų balanso išlaidų dali sudaro: 1) kasmečiam metiniam augalų prieaugiui sunaudotas azoto ir pelenų elementų kiekis; 2) anglies nuostoliai mineralizuojantis organinei medžiagai ir humusui; 3) azoto nuostoliai dél denitrifikacijos; 4) medžiagų išplovimas su prasisunkiančia drègme iš dirvožemio profilio i gruntinius vandenis; 5) medžiagų išplovimas su šoninio požeminio nuotèkio vandenimis; 6) medžiagų išplovimas su kietomis paviršinio nuotekio dalelèmis; 7) medžiagu išplovimas su paviršinio nuotèkio vandenimis; 8) medžiagų nuostoliai dèl nupustymo (defliacijos); 9) azoto ir mineralinių elementu, sukauptų žemès ūkio produkcijoje ir medienoje, išvežimas (Jankauskas 2006).

Medžiagų balansui didžiausios įtakos turi bioklimatinès sąlygos ir reljefas.

Skirtingų bioklimatinių zonų dirvožemiuose skiriasi tiek medžiagų balanso pajamų tiek išlaidų dalys. Pavyzdžiui, anglies su augalinėmis liekanomis i dykumų dirvožemi patenka $<1000 \mathrm{~kg} \mathrm{ha}^{-1}$, drègnu atogrą̌ų miškuose $->14000$ $\mathrm{kg} \mathrm{ha}^{-1}$; mikroorganizmų sujungto (fiksuoto) azoto kiekis ivvairių gamtinių zonu dirvožemiuose gali būti įvairios nuo 10 iki $5000 \mathrm{~kg} \mathrm{ha}^{-1}$, medžiagų nuostoliai dèl paviršinio nuotèkio - nuo 0 iki $300 \mathrm{~kg} \mathrm{ha}^{-1}$ (Bridges 1998).

Ypač svarbios biogeninès medžiagos dirvodaros maisto medžiagų elementai, kadangi augalai i biologinę apykaitą itraukia ir sugrąžina dirvožemiui elementų kelis kartus daugiau palyginti su tuo jų kiekiu, kuris patenka ị dirvožemi ir vèl iš jo pašalinamas abiogeniškai. Pavyzdžiui, juodžemiuose per metus biogeninio azoto sujungiama ir vèliau išvežama $\sim 14000 \mathrm{~kg} \mathrm{ha}^{-1}$, išplaunama su paviršiniu nuotèkiu ir t. t. tik $400 \mathrm{~kg} \mathrm{ha}^{-1}$. Minètuose drègnų tropikų miškuose šie skaičiai per metus, atitinkamai, sudaro $25000 \mathrm{~kg} \mathrm{ha}^{-1}$ ir $900 \mathrm{~kg} \mathrm{ha}^{-1}(\mathrm{~Pa}-$ škauskas 2001). 
Medžiagų balansas dirvožemyje, kaip minèjome, priklauso ir nuo reljefo sąlygų, t. y. kokiame šlaito elemente formuojasi dirvožemis - jo viršuje (eliuviniame elementariajame arba išplaunamajame, geocheminiame landšafte), viduryje (tranzitiniame eliuviniame elementariajame geocheminiame landšafte) ar apačioje (akumuliaciniame elementariajame geocheminiame landšafte) (Jankauskas 2006).

Medžiagų balansas dirvožemyje būna teigiamas, neigiamas arba nulinis. Pažymètina, kad ịvairių medžiagų balansas tame pačiame dirvožemio profilyje gali būti visiškai elementų pobūdžio. Esant teigiamam balansui, dirvožemyje vyksta medžiagų akumuliacija, kuri gali būti absoliutinè, santykinè ir likutinè.

Labai svarbi dirvožemyje atmosferos anglies ir azoto absoliutiné akumuliacija, vykstanti dèl žaliujų augalų ir azotą fiksuojančių mikroorganizmų gyvybinès veiklos. Nèra nė vieno dirvožemio, kuriame nevyktų absoliutinis $\mathrm{C}$ ir $\mathrm{N}$ kaupimasis. Nors šie elementai daugiausia kaupiasi miško pakloteje arba stepių veltinyje ir humusiniame horizonte, tačiau nemažai juc galima aptikti ir visuose likusiuose dirvožemio profilio horizontuose. Absoliučiai medžiagos i dirvožemi gali akumuliuotis ir iš gruntinio vandens, taip pat dèl paviršinio ar šoninio vandens prietakos. Tokio pobūdžio akumuliacija vyksta sausringo klimato dirvožemiuose. Absoliutinę akumuliaciją taip pat gali lemti kietų dirvožemio dalelių priemaiša su potvynių ar deliuvinio nuotekio vandenimis vykstant defliacijai bei išsiveržus vulkanams, t. y. formuojantis salpžemiams (Fluvisols), vulkanžemiams (Andosols) ir supustytiesiems eoliniams smèlžemiams (Arenosols) (Janušienè 2004).

Vykstant santykinei akumuliacijai, viršutiniuose dirvožemio profilio horizontuose pastebimai padideja mineralinių biofilinių elementų, augalų iš apatinių horizontų, nors į dirvožemị apskritai jokių medžiagų iš šalies ir nebuvo įnešta. Apie ìvairių elementų santykinès akumuliacijos intensyvumą galima spręsti iš biologinio įsisavinamumo koeficiento $A_{x}$ reikšmių (1.1):

$$
A_{x}=\frac{l_{x}}{n_{x}}
$$

čia $l_{x}$ - elemento $x$ kiekis augalų pelenuose; $n_{x}$ - elemento $x$ kiekis dirvožemyje, kur auga augalai.

Panašų koeficientą galima apskaičiuoti iš elemento klarko. Didžiausias biologinis įsisavinamumas tokių elementų, kaip P ir S (100 n), Ca, K, Mg (10 n), $\mathrm{Mn}, \mathrm{Cu}$, Mo (1 n), o mažiausias - Si, Al, Fe, Ti, V (0,1 n - 0,001 n) (А. И. Перельман, 1991).

Neigiamas medžiagų balansas esti tuomet, kai medžiagų išnešama daugiau negu inešama. Tai dažniausiai vyksta drègno klimato, ypač eroduojamuose kalnų šlaitų dirvožemiuose. Medžiagų sumažejjimas gali būti dalinis arba bendrasis. Bendrasis mažejjimas yra tuo atveju, kai tam tikro komponento pastebimai mažèja visame dirvožemio profilyje, pvz., jauražemių (Podzols) profilyje katijonų. 
Dalinis mažejjimas - tai tam tikro komponento mažejimas tik viršutiniame dirvožemio horizonte, o ne visame profilyje.

Nulinis balansas būdingas tiems dirvožemiams, kuriuose medžiagų išnešimas ir inešimas yra subalansuotas (Motuzas 1996).

\subsection{Dirvožemio organinẻ medžiaga}

Organinė medžiaga yra vienas iš svarbiausių elementų, darančių įtaką dirvožemio potencialiam derlingumui. Dirvožemio organinè medžiaga, kaip pagrindinis Saulès energijos akumuliatorius, struktūriškai ir funkcionaliai dalyvaujantis ekosistemu fundamentiniuose procesuose, lemia dirvožemio fizikines ir chemines savybes, kurios turi ịtakos augalų mitybos režimui ir yra gyvybiškai svarbios augalų augimui (Danilevičius 1977).

Organines medžiagas dirvožemiuose kaupia gyvieji organizmai. Augalai fotosintezès dèka iš aplinkinio oro ir vandens $(93,5 \%)$, taip pat iš dirvožemio mineralinių medžiagu (6,5\%) sintetina organines medžiagas. Augalams numirus, jų sukauptos organinès medžiagos lieka viršutiniuose dirvožemio sluoksniuose, kur jas perdirba sudètingas dirvožemio mikroorganizmų pasaulis (Čaikauskas 1985). Susintetintomis augalų maisto medžiagomis minta ir visi kiti gyvieji organizmai, kurie, baigę savo gyvenima, taip pat lieka dirvožemio paviršiuje. Visų augalų susintetintą ir gyvūnų liekanų organinę medžiagą dirvožemio mikroorganizmai perdirba į sudètinga, labai aktyvią dirvožemio organinę - mineralinę medžiaga - humusą, arba puvenas. Humusas - svarbiausias dirvožemio derlingumo rodiklis (Žalakevičius 2005, Janušienė 1992 ir Janušienė 1994, Brandy 1999).

Organinių medžiagu kaupimasis dirvožemyje labai priklauso nuo jau aptartos dirvožemių granuliometrinès sudèties o tai pat nuo klimatinių sąlygų. Lengvos granuliometrinès sudèties dirvožemiuose mažiau organinių medžiagų sukaupiama dèl blogesnių augalų augimo sąlygų. Kita vertus, organinès medžiagos čia sparčiai ardomos dèl aktyvios aerobinių mikroorganizmų veiklos, greitesnio jų ǐšilimo, o mineralizuotas medžiagas lengvai išplauna vanduo (Lipson 2000). Tokiuose dirvožemiuose susikaupia nedaug humuso, dèl to menkas jų derlingumas. Pelkiniuose dirvožemiuose, kur organinès medžiagos dèl anaerobinių mikroorganizmų veiklos (trūksta oro, žemesnè temperatūra) irsta lèčiau, jos ilgai išlieka tarpinèse irimo stadijose. Šios medžiagos sparčiai kaupiasi, bet jų maisto medžiagos dèl lètos mineralizacijos augalų sunkiai pasisavinamos. Tokiuose dirvožemiuose natūraliai gali augti tik nedaugelis ten prisitaikiusių augalų (Jankauskas 2005, Antanaitis 1996, Janušienè 1994).

Dirvožemio organines medžiagas $80-85 \%$ sudaro humusas, $10-15 \%$ nesuirusios augalų liekanos ir šaknys ir iki 5\% - gyvieji organizmai (1.1. pav.). Pagrindinis dirvožemio organinès medžiagos šaltinis ekosistemoje - tai organinès 
medžiagos, produkuojamos augalų fotosintezès metu ir nedideliu mastu autotrofinèmis dirvožemio bakterijomis (Janušienè 2004, Jenkyn 2001). Žemès ūkio naudmenose tai gali būti ir gyvulinès kilmès organinès trąšos. Ivairiose klimatinèse zonose metinis fitomasès prieaugis ir nuokritu masè yra nuo 1,0 iki 24,5 t ha $^{-1}$ sausujų medžiagu (Danilevičius 1977). Patekusios ị dirvožemio ekosistemą organinès medžiagos gali: 1) visiškai mineralizuotis ir tokiu būdu praturtinti anglies dioksido ir mineralinių medžiagų atsargas; 2) būti panaudotos mikroorganizmų mitybai ir asimiliuoti mikrobinèje biomaseje; 3) būti jjungtos i naujai susidariusias humusines medžiagas, tai yra humiflkuotis (Baginskas 1984). Šių pokyčių greitis ir kryptis priklauso nuo daugelio veiksnių, tarp jų nuo dirvožemio mikroorganizmų kiekio ir jų veiklos intensyvumo, nuo dirvožemio ir klimato sąlygų, nuo augalų liekanų kiekio ir jų cheminès sudeties ir kt. Humuso medžiagų susidarymas - tai ne paprastas organinių liekanų utilizavimas, kuris būtinas biosferoje. Svarbiau tai, kad šio proceso eigoje susidaro nauja grupé gamtinių, neegzistuojančių gyvuose organizmuose, junginių kurie būtini, kad užtikrintų nenutrūkstamą šiuolaikinių gyvujų formų egzistavimą (Baginskas 1984, Kaboneka 2000).

Organinès medžiagos irimas - tai ilgas ir sudètingas mechaninių, biologinių ir cheminių reiškinių procesas. Bakterijos aktyviai ardo ląstelieną ir angliavandenius, aktinomicetai - pektino medžiagas, celiuliozę, riebiąsias rūgštis, grybai ligniną ir taninus, dirvožemio gyvūnai smulkina augalų liekanas ir padaro jas tinkamesnes mikroorganizmams ardyti. Bakterijos, aktinomicetai, bestuburiai gyvūnai ir augalai dirvožemyje pagausina fermentu̧, kurie yra labai svarbūs cheminių reakcijų katalizatoriai, spartinantys organinès medžiagos irimo ir sintezès procesus. Žuvę mikroorganizmai ir gyvūnai dirvožemyje organinès medžiagos per metus pagausina vidutiniškai 100-200 kg ha ${ }^{-1}$ (Lampkin 1999).

Dirvožemio susidarymo eigoje vyko azoto ir organinès medžiagos akumuliacija viršutiniame horizonte. Jos kiekis dirvožemyje - vienas iš svarbiausių dirvožemio derlingumo rodiklių ir daro i̇vairiapusę itaką dirvožemio agrocheminèms, fizikinèms savybèms, biologiniam aktyvumui, buferingumui. Organinèje medžiagoje akumuliuota $98 \%$ dirvožemio azoto, $80 \%$ sieros, $60 \%$ fosforo, didelis kiekis kitų makro ir mikroelementų. Sujungti organiniuose junginiuose šie elementai apsaugoti nuo išplovimo ir yra svarbiausias maistingujų elementų šaltinis augalams. Didžiają dali dirvožemio organinès medžiagos sudaro humusas, kuris formuojasi iš augalų liekanu̧, dalyvaujant gyvūnams, mikroorganizmams. Tai sudètingas biocheminis procesas, kurio metu susidaro specifiniai organiniai junginiai - humuso rūgštys (Tripolskaja 2005). 


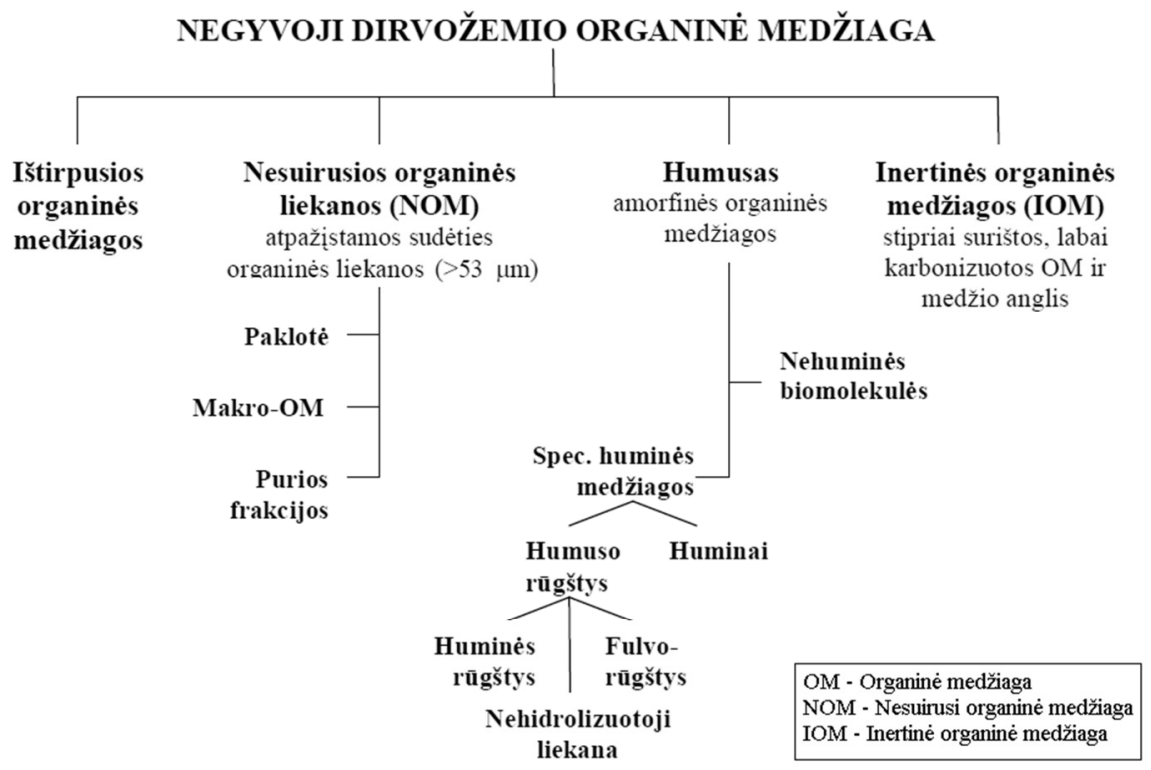

1.1. pav. Dirvožemio organinès medžiagos sudètis (patikslinta pagal J. A. Baldock ir J. O. Skjemstad) (Tripolskaja 2005)

Fig. 1.1. Soil organic matter composition (modified according to the JA Baldock and JO Skjemstad) (Tripolskaja 2005)

Specifinès dirvožemio humuso rūgštys yra huminės rūgštys, fulvorūgštys ir nehidrolizuotoji liekana, arba huminas. Huminès rūgštys - tai didelès molekulinės masès organinės rūgštys, turinčios azoto, netirpios vandenyje ir mineralinėse rūgštyse (1.1. pav.). Jų sudètyje anglies yra 50-62 \%, deguonies 31-40\%, vandenilio 2,8-6,6\% ir azoto 2-6\% (Tripolskaja 2005). Laisvos huminès rūgštys dirvožemyje daugiausia yra gelių pavidalo, kurie, šarminių junginių paveikti, lengvai peptizuojasi ir sudaro molekulinius ir koloidinius tirpalus. Laisvos huminès rūgštys turi po kelias karboksilines $(-\mathrm{COOH})$, metoksilines $\left(-0-\mathrm{CH}_{3}\right)$, hidroksilines $(-\mathrm{OH})$ laisvas grupes, kurios, reaguodamos su esančiais dirvožemyje katijonais, sudaro druskas, vadinamas humatais. Vienvalenčių katijonų $\left(\mathrm{Na}^{+}, \mathrm{K}^{+}, \mathrm{NH}_{4}^{+}\right)$humatai gerai tirpsta vandenyje, todèl kritulių vanduo juos lengvai išplauna iš humusingo horizonto gilyn. Dvivalenčių katijonų $\left(\mathrm{Ca}^{+2}\right.$, $\mathrm{Mg}^{+2}$ ) humatai vandenyje netirpsta ir sudaro patvarius gelius, kurie plona plèvele apgaubia mineralines dirvožemio daleles ir jas sulipdydami sudaro vandeniui atsparią dirvožemio struktūrą. Huminès rūgštys ir humatai su mineralinèmis dirvožemio dalelèmis, ypač molio mineralais, sudaro sudètingus organiniusmineralinius mikroagregatus (Орлов 1990, Nelson 1982). 
Fulvorūgštys - didelès molekulinès masės organinės rūgštys, turinčios azoto, tirpstančios vandenyje, rūgštyse ir šarmuose. Fulvorūgštyse yra žymiai mažiau anglies (40-52\%), o daugiau deguonies (40-48\%) negu huminèse rūgštyse (Эйдукявичене 1993). Fulvorūgštys su katijonais sudaro įvairias druskas - fulvatus. $\mathrm{Na}^{+}, \mathrm{K}^{*}, \mathrm{NH}^{+}$fulvatai gerai tirpsta vandenyje, o šarminių žemès metalų $(\mathrm{Ca}, \mathrm{Sr}, \mathrm{Ba})$ fulvatai vandenyje netirpsta tik esant labai šarminei terpei. Fulvorūgštys, būdamos labai stiprios rūgštys, aktyviai ardo dirvožemio mineralus, sudarydamos naujus junginius (Tripolskaja 2005, Возбуцкая 1964).

Huminas (nehidrolizuotoji liekana) - pati inertiškiausia humuso dalis, netirpstanti silpnuose šarmuose. Huminas savo prigimtimi artimas huminėms rūgštims, tačiau labiau susijęs su dirvožemio molio mineralais. Šioje humuso frakcijoje akumuliuota 20-30\% dirvožemio suminio azoto kiekio. Huminas mažiausiai skaldomas dirvožemio mikroorganizmų (Danilevičius 1997, Tripolskaja 2005).

Pagrindinis humuso kokybès rodiklis yra jo sudetyje esančių huminių ir fulvorūgščiu santykis: kuo jis didesnis, tuo geresnès kokybės humusas. Lietuvos dirvožemiuose fulvorūgščiu dažniausiai yra daugiau nei huminių rūgščiu̧, ypač rūgščiuose išplautžemiuose ir balkšvažemiuose. Ivairios agrotechnikos priemonès gali turèti skirtingą itaką huminių rūgščių santykiui. Tokios agrotechnikos priemonès, kaip rūgščių dirvožemių kalkinimas, tręšimas méšlu, daugiamečių žolių auginimas, skatina huminių rūgščių sintezę ir jų kaupimąsi dirvožemyje.

Labiau humusingi yrą sunkesnès granuliometrinès sudèties dirvožemiai moliai, priemoliai, mažesniu humusingumu pasižymi priesmèliai ir smèliai. Ši skirtumą lemia nevienodas kiekis molio dalelių, kurios su organiniais koloidais sudaro organinius mineralinius derinius bei aktyvesnę organinès medžiagos mineralizaciją, dèl kurios organinès medžiagos suskyla iki paprastų junginių (Krištaponytė 1996, Воронин 1986).

Smèliai, kuriuose fizinio molio dalelių mažiau kaip 10\%, labai laidūs vandeniui, bet dèl menko jų rišlumo, susidarius vandens nuotèkiui, jie lengvai pasiduoda vandens erozijai, labai greitai išdžiūsta. Tada jiems pavojinga vèjo erozija. Smėlio dirvožemiuose mažai organinių ir mineralinių maisto medžiagų. Jas lengvai išplauna besisunkiantis vanduo. Dèl to smèlio dirvose skursta dauguma augalų. Todèl ir nuo erozijos jie menkai tesaugo (Krištaponytè 1996, Danilevičius 1997).

Molio dirvožemiuose fizinio molio dalelių yra daugiau kaip 50\%. Dèl to jie gana rišlūs, bet menkai laidūs vandeniui. Ilgesnių ir gausesnių lietų metu jų paviršiuje susikaupia ir ilgai telkšo vanduo. Kalvose jis teka $\mathfrak{i}$ žemesnes vietas ir pamažu ardo dirvožemi (Ežerinskas 1996). Smulkios molio dirvožemių poros dažnai būna pilnos vandens, juose trūksta oro, plinta anaerobiniai mikroorganizmai, sulèteja organinių medžiagų mineralizacija. Sausringu periodu viršutinis tokių dirvožemių sluoksnis pasidengia kieta pluta, jis suskeldèja, augalai dūsta dèl oro trūkumo, šaknys sunkiai pasiekia gilesnius jo sluoksnius (Mažvila 1992). 
Priesmèliuose fizinio molio dalelių būna nuo 10 iki $20 \%$. Dèl to jie rišlesni už smèlius, gali sukaupti daugiau maisto medžiagų ir organinès anglies, mažiau laidūs vandeniui. Juose augalų augimo sąlygos palankesnès, bet jie gana lengvai praleidžia vandeni, nedaug jo ir sukaupia, todèl jų erozija gana didelè (Krištaponytė 2002, Lohnston 1986).

Išaiškinti molio kiekị dirvožemiuose naudojamasi Fere trikampiu (1.2 pav.). Šioje klasifikacijoje dirvožemio granuliometrinè sudetis nustatoma pagal viso smulkžemio: smèlio $(2-0,05 \mathrm{~mm})$, dulkių $(0,05-0,005 \mathrm{~mm})$ ir dumblo $(<0,002$ $\mathrm{mm}$ ) kiekio, išreikšto procentais, santyki. Be to, skirtingai nuo N.Kačinskio klasifikacijos, dumblo frakcijai priskiriamos dalelès, mažesnès kaip $0,002 \mathrm{~mm}$, o ne $0,001 \mathrm{~mm}$ (Motuzas 1996, Dirvožemio agrocheminio tyrimo medžiaga 19631993).

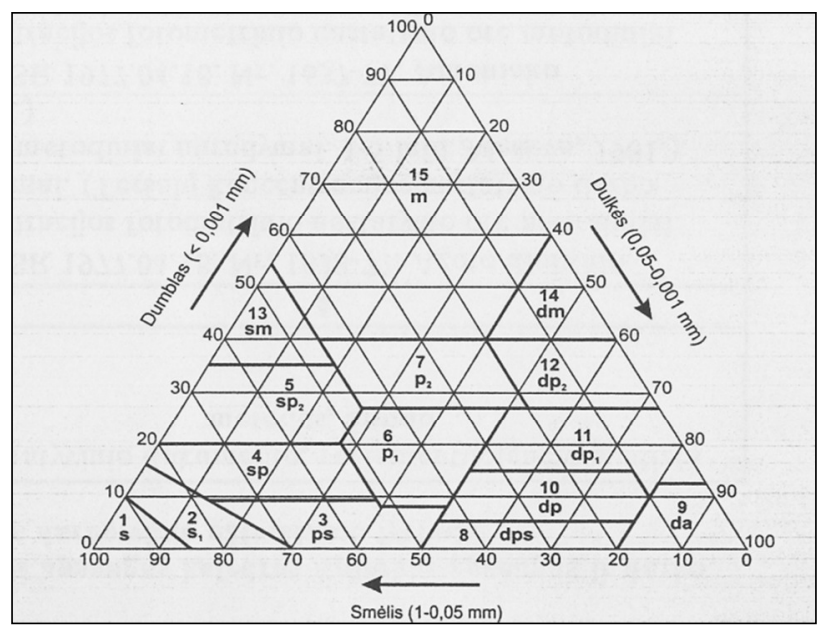

1.2. pav. Fere trikampis dirvožemio granuliometrinei sudèčiai nustatyti (Juodžio, 1998)

Fig. 1.2. Fere soil texture triangle to determine the composition (Juodžio, 1998)

Pagal modifikuotą Fere trikampi Lietuvos dirvožemiai pagal granuliometrinę sudètị skirstomi ị 15 klasių (Motuzas 1996): smèlis, rišlus smèlis, priesmèlis, smèlingas lengvas priemolis, smèlingas sunkus priemolis, vidutinio sunkumo priemolis, sunkus priemolis, dulkiškas priesmèlis, dulkès, dulkiškas lengvas priemolis, dulkiškas vidutinio sunkumo priemolis, dulkiškas sunkus priemolis, smèlingas molis, dulkiškas molis, molis. 


\subsection{Dirvožemio oksidacinės-redukcinès savybẻs}

Plačiai paplitęs oksidacijos procesas - organinių medžiagų irimas dirvožemyje. Pavyzdžiui, dirvožemyje tirozinas ir kitos aromatinès amino rūgštys oksiduojamos ị melaninus; būna dervų oksidacija; taip pat vyksta rauginių medžiagų, cukrų, amino rūgščių, baltymų ir kitų medžiagų oksidacija. Humifikacija irgi yra oksidacijos procesas (Apalia 1982).

Dauguma dirvožemio organinių medžiagų oksidacijos reakcija yra negrižžtamoji. Grį̌tamoji oksidacijos-redukcijos reakcija dirvožemyje yra geležie, mangano, azoto oksidacijos ir redukcijos reakcija. Kadangi dauguma šių reakcijų yra biocheminès ir labai susietos su mikrobiologiniais procesais, tai suprantama, kad jie turi tiesioginę itaką oksidacijos-redukcijos procesams (Tripolskaja 2005, Мпшустпн 1978, Алексеев 1987).

Pagrindinis oksidatorius dirvožemyje yra dirvožemio oro ir dirvožemio tirpalo molekulinis deguonis. Dèl to oksidacijos-redukcijos procesai dirvožemyje labai susiję su aeracija, t. y. su visomis dirvožemio savybėmis, lemiančiomis dujų apytaką (struktūra, gludumas, mechaninè sudètis ir t. t.).

Svarbiausios sąlygos, lemiančios oksidacijos-redukcijos procesus, yra dirvožemio drègnumas ir aeracija, taip pat organinių medžiagų kiekis dirvožemyje bei temperatūra.

Sumažèjus aeracijai, padidejus dirvožemio drègnumui, gludumui, susidarius plutelei, oksidacijos-redukcijos procesai susilpnèja, sumažeja jų potencialas. Potencialas labai sumažeja tada, kai dirvožemio drègnumas būna lygus pilnam vandens imlumui, kai sutrinka dirvožemio ir atmosferos dujų apytaka. Dèl to labai sumažèja velèninių jaurinių dirvožemių humusingų horizontų (A, A1) potencialas, kai dirvožemio drégnumas būna didesnis negu $90 \%$ pilno vandens imlumo. Drègnumui didejjant nuo 10 iki $90 \%$ pilno vandens imlumo, potencialas mažèja pamažu. Kai temperatūra ir drègnumas optimalūs, velèninių jaurinių dirvožemiu ariamajame horizonte aerobinès sąlygos virsta anaerobinèmis tada, kai dirvožemio ore deguonies būna 2,5-5,0\%. Velèniniuose jauriniuose priemolio dirvožemiuose, apaugusiuose daugiametėmis žolèmis, anaerobiniai procesai vyksta tada, kai drègnumas būna daugiau kaip $80 \%$ pilno vandens imlumo, o poringumas $-6 \%$. Daug itakos oksidacijos-redukcijos procesams turi organinių medžiagų kiekis bei forma. Per drègnų dirvožemių potencialas labai sumažèja tik humusingų horizontų (Motuzas 1996, Beliauskas 1976).

Oksidacijos-redukcijos potencialas nustatomas ịstačius i dirvožemi platinini elektroda. Oksidacijos-redukcijos potencialas matuojamas milivoltais (mV). Dauguma augalų normaliai auga ir vystosi tada, kai dirvožemio $E_{h}$ yra 200-700 $\mathrm{mV}$. Sumažèjus dirvožemio drègnumui, susidarius plutai ar dèl kitokių priežasčiu pablogèjus dirvožemio aeracijai, oksidacijos-redukcijos potencialas gali smarkiai sumažèti. Kai $E_{h}$ mažesnis kaip $200 \mathrm{mV}$, dirvožemyje prasideda inten- 
syvūs redukcijos procesai ir atsiranda glejjiškumo požymių, nitrifikaciją pakeičia denitrifikacija, kadangi nitrifikacijai optimaliausias potencialas $350-500 \mathrm{mV}$. Žinant oksidacijos-redukcijos potenciala, galima spręsti, kokie procesai vyksta dirvožemyje (Bundinienè 2002, Motuzas 1996, Воронин 1986, Гилярова 1975).

\subsection{Anglies apykaitos ciklas dirvožemyje}

Anglies apykaitos ciklas - biogeocheminis ciklas, apimantis ivairius cheminius, fizinius, geologinius ir biologinius procesus, kuriais anglis juda Žemès biosferoje, geosferoje, hidrosferoje ir atmosferoje (kiti astronominiai kūnai taip pat gali turèti atitinkamus ciklus, tačiau šiuo metu tai nèra žinoma) (Batjes 1996, Ягодина 1982).

Patekusios į Žemès paviršių (formuojantis Žemès plutai, išsiveržiant vulkanams ir t.t.) pirminès kalnų uolienos pradeda dūlèti, irti. Paviršiniame šio dūlo sluoksnyje pradeda formuotis dirvožemis kaupdamas reikiamas maisto medžiagas gyviems organizmams. Tos medžiagos iš dirvožemio pasisavinamos augalų ir po to vèl per tarpinius trofinius ciklus (augalai - gyvūnai - mikroorganizmai) grižta atgal i dirvožemi - mažoji biologinè medžiagų apykaita. Iš dirvožemio dalis medžiagų su infiltracinių atmosferos kritulių srautu išplaunama ir per hidrografini tinklą patenka ị pasaulinį vandenyną. Čia iš jų susidaro nuosẻdinès uolienos, kurios dèl geologiniu procesų gali grižti i planetos paviršių, ir vèl jose formuosis dirvožemis, ar pasilikti vandenyno gelmèse ir iš esmès pagristi (metamorfizuotis) - didžioji geologinè medžiagų apykaita. Pradžioje, t.y. abiotiniame laikmetyje, šie globaliniai medžiagų migracijos -transformacijos srautai buvo tik kaip geocheminiai ciklai. Žemeje atsiradus gyvybei, jie tapo biogeocheminiais ciklais, kurie civilizacijos eigoje palaipsniui transformavosi i technogeninius ciklus. Pastarujų ciklų svarba globalineje medžiagų migracijoje nuolat didèja. Tarkime, tokių globalinių ciklų, kaip anglies, vandens, azoto, sieros ir daugelio kitų elementų bei medžiagų intensyvumą, šiandien jau itin lemia žmogaus, tapusio savotišku geologijos veiksniu, veikla. Technogeninè veikla keičia ne tik gamtinių ciklų intensyvumą, bet ir jų pobūdi, t. y. medžiagų persiskirstymo Žemès paviršiuje tvarką (Lal 1998, Bazzaz 1997, Motuzas 1996, Danilevičius 1977, Bohn 1976).

Bendras technobiogeocheminès medžiagų apytakos Žemejje ciklas susideda iš daugelio atskirų biogeninių, abiotinių, geologinių ir technogeninių ciklų, sudarančių didžiają geologinę medžiagų apykaitą (1.3 pav.).

Savo ruožtu pastaroji susideda iš šių svarbiausių ciklų (etapų): magminių uolienų Žemès paviršiuje pasirodymas - dūlejimas - dirvodara - ardymas ir denudacija - nuosedų kaupimasis sausumoje ir vandenynuose - kritulių metamor- 
fizacija - Žemės paviršiuje pasirodymas nuosedinių uolienų su naujai prasidèjusiais jų dūlèjimo, dirvodaros, denudacijos bei nuosèdų kaupimosi ciklais, arba jų nugrimzdimas geosinklinose i mantija, perlydymas ir pakartotinis pasirodymas Žemès paviršiuje.

Šią aptartą bendrą didžiosios geologinès medžiagų apykaitos schemą labai komplikuoja Žemès plutos ir joje vykstančių tektoninių procesų savitumai. Tam tikrą dali didžiają geologinę medžiagų apytaką sudarančių elementariujų ciklų jau galima įvertinti ir kiekybiškai. Tai itin svarbu ir nustatant jų reikšmę dirvodaroje ir ịvertinant dirvožemio svarbą šiuose cikluose. Apskritai visi šie elementarieji ciklai yra labai sudètingi ir šiuo metu kiekybiškai juos įvertinti galime dažniausiai tik preliminariai. Be to, jie dèl vis didejjančio antropogeninio poveikio nuolat kinta (Motuzas 1996).

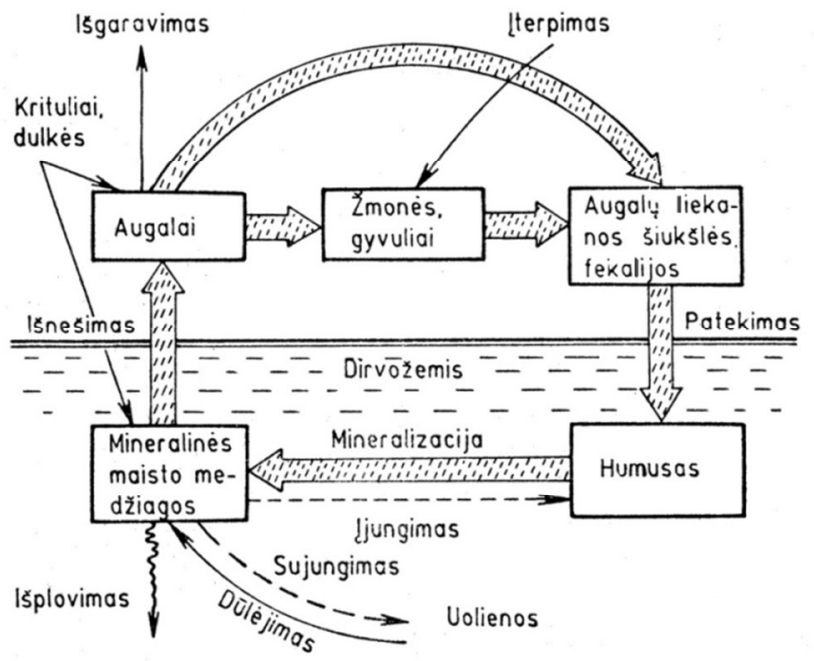

1.3. pav. Didžiosios geologinės medžiagų apykaitos gamtoje schema (Motuzas 1996)

1.3. pav. Great geological nature of metabolic scheme (Motuzas 1996)

Svarbiausi didžiojoje geologinèje medžiagų apykaitoje yra mažieji biologiniai ir technosferiniai ciklai, kadangi i juos patekę elementai ilgam pašalinami iš globalinio geocheminio srauto ir daug kartu dalyvauja niekad nenutrūkstančiuose įvairių medžiagų kitimo procesuose. Itin svarbi dirvodarai yra mažoji biologinè medžiagu apykaita, lemianti ciklišką dirvodaros biogeocheminę dinamiką. Šios apykaitos esmę, kaip minėjome, lemia augalų įsisavinimas peleninių elementų iš dirvožemio, jų itraukimas i biocheminius procesus ir grąžinimas i dirvožemị apmirus augalams (dali jų pasisavina gyvuliai ir grąžina dirvožemiui po žūties). Daug sudètingesni yra anglies ir azoto ciklai, apimantys ir atmosferą. 
Dalis po organizmų apmirimo išsilaisvinusių elementų per atmosferą ir hidrosferą vèl grižta i didžiają geologinę apykaitą, bet, antra vertus, dèl vykstančių dūlèjimo ir dirvodaros procesų $\mathfrak{i}$ biologinę apytaką itraukiamos ir naujos elementų porcijos.

Žmogaus ūkinè veikla labai keičia biologinès medžiagų apykaitos pobūdi dèl šių veiksnių kompleksinio poveikio: a) natūralių gyvujų organizmų bendrijų sunaikinimo ir pakeitimo nauja sukultūrinta; b) biologinès produkcijos išvežimo ir sunaudojimo už tos ekosistemos, kurioje ji buvo išauginta, ribų; c) dirbtinių trąšų ir kitų cheminių medžiagų i̇terpimo; d) dirvožemio režimo ir biogeocheminès elementų migracijos sąlygu pasikeitimo $(\mathrm{pH}, \mathrm{Eh}$, sausinimo, drèkinimo ir pan.) (Bundinienè 2000).

Bet kurio elemento apykaitos intensyvumas arba imlumas priklauso nuo to, kiek jo reikia organizmams (elemento biofiliškumo) ir nuo jo prieinamų organizmams atsargu kiekio aplinkoje. Ivairios gamtinès ekosistemos labai skiriasi viena nuo kitos ir bendru biologinés apykaitos intensyvumu, ir i ją itrauktų elementų kiekiu. Iš esmès šiuo požiūriu, pavyzdžiui, skiriasi spygliuočių ir lapuočių miškai. Ploto vienetui pirmieji sunaudoja beveik 4 kartus mažiau kalio, 2,5 karto kalcio, 3 kartus mažiau magnio, tačiau pagal azoto, fosforo ir sieros sunaudojimą šie miškai mažai skiriasi (Bundinienė 2000).

Apie didžiosios geologinès medžiagų apykaitos ir dūlejjimo procesų intensyvumą orientaciškai galima spręsti iš bendro sausumos žemèjimo masto.

Pagal V. Kovdą ir B. Rozanovą, denudacini Žemès rutulio metini balansą (57,0 mlrd. t) sudaro; egzogeninès (iš šalies) prienašos (4 mlrd. t), medžiagų išnašos i vandenyną $(27,1 \mathrm{mlrd}, \mathrm{t})$, i žemynų vandenis $(18,2 \mathrm{mlrd}$. t) ir i atmosferą $(7,7$ mlrd. t). Atliekant šiuos skaičiavimus, nebuvo atsižvelgta $\mathfrak{i}$ endogenines (vidines) prienašas, susidariusias vykstant didžiajai geologinei medžiagų apykaitai, t. y., i galimą medžiagų prietaką iš planetos gelmių (Danilevičius 1977).

Pateiktos vidutinès denudacijos reikšmès visgi nieko konkretaus nepasako apie jos mastą ivairiuose Žemès paviršiaus taškuose. Viena vertus, iš viso medžiagų iš kalnuotų teritorijų turètų būti išnešta bent 3 kartus daugiau nei iš lygumų (jos užima 77 proc. Žemès sausumos). Antra vertus, suintensyvejusi antropogeninè lygumų denudacija lemia tai, kad bendra sausumos paviršiaus denudacija būna intensyvesnè lygumose nei kalnuose. Manoma, kad bendra antropogeninè sausumos denudacija šiuo metu vidutiniškai viršija fono 1,5 karto. Dèl itin intensyvios žmogaus veiklos tam tikruose Žemès paviršiaus sausumos taškuose geologinè denudacija padidèja ne mažiau kaip 1000 kartų, palyginti su erdvėmis, nepatyrusiomis šios veiklos (Feiza 2004, Eitminavičiūtė 1997).

Ypač reikšmingi paviršiaus žemèjimo pokyčiai vyksta žmogui pakeitus augalijos sudèti. Gamtinio sausumos fono žemèjimą kompensuoja vis naujų pirminių kalnų uolienų sluoksnių iškilimas į paviršių vykstant dūlejjimui. Kaip tik dèl to iki šiol pavyksta išlikti vienodam planetos dirvožemio dangos storiui. Taip pat 
palaikomas ir jos biogeocheminis atsparumas, nes i dūlejimą ir dirvodarą įtraukiami vis nauji kalnų uolienų pirminiai mineralai (nepaisant to, kad elementai nuolat išplaunami i vandenyna).

Vykstant antropogeninei denudacijai, kuri savo intensyvumu vidutiniškai kelis kartus viršija gamtini foną, išryškejja, viena vertus, kad dūlèjimas atsilieka nuo denudacijos ir nekompensuoja patirtų elementų nuostolių, dèl to mažejac, visos biosferos stabilumas ir produktyvumas. Antra vertus, vykstant antropogeninei denudacijai, sunaikinami patys humusingiausi ir daugiausia biofilinių elementų turintys paviršiniai dirvožemių horizontai, todèl dar labiau pažeidžiamas biosferos funkcionavimas. Visa tai sudaro sąlygas plèstis antropogeninių dykumų plotams, kurie šiuo metu užima ne mažiau kaip 30 proc. Žemès rutulio sausumos (Jankauskas 1996, 2004).

\subsection{Dirvožemio dujinè fazè}

Dirvožemio oras (dujinè fazè) yra viena iš dirvožemio sudedamujų dalių. Jis yra deguonies šaltinis augalų "šaknims ir aerobiniams mikroorganizmams: oras dirvožemyje trejopas: a) laisvas, užimantis-tuščias (be vandens) poras arba jų dali; b) sorbuotas dirvožemio dalelių paviršiaus; c) ištirpęs dirvožemio vandenyje.

Dirvožemio oro sudètis nepastovi. Ji priklauso nuo jo kiekio ir judejimo dirvožemyje, nuo biocheminių ir kitokių procesų ir labai skiriasi nuo atmosferos oro sudèties. Ypač kinta deguonies kiekis intensyvios augalų vegetacijos ir biologinių procesų periodu, pavyzdžiui, dèl intensyvios nitrifikacijos. Kai labai padaugèja nitratų, tai sumažèja deguonies, ypač per drègnuose dirvožemiuose. Optimalios sąlygos augalams vystytis būna tada, kai dirvožemio ore deguonies yra apie 20\% (Feizienè 2009, Arlauskienè 2002).

Dèl organinių junginių oksidacijos labai padaugejja anglies dioksido dirvožemio ore. Deguonies dirvožemio ore randame mažiau tada, kai jo daug naudojama, kai augalai gerai vystosi ir kai mikrobai būna aktyvūs. N. Cholodnovas irodè, kad dirvožemio ore ir pažemès ore yra lakių organinių junginių, kuriuos kaip maisto medžiagas ịsavina bakterijos ir aukštesnieji augalai (Feizienė 2009, ASA, 1990 ir 1993, Воронин 1986).

Dirvožemio oro sudetis kinta einant gilyn: kuo giliau, tuo daugiau būna anglies dioksido, o mažiau deguonies. Kai kada 150-200 cm gylyje anglies dioksido būna $10-12 \%$ (ASA, 1990 ir 1993)

Dujas ir vandens garus sorbuoja dirvožemio kietosios dalelès, ir išsiskiria sorbcijos, arba drékimo, šiluma. Dujos dirvožemio kietujų dalelių sorbuojamos pagal tokią eilę: $\mathrm{H}_{2} \mathrm{O}>\mathrm{NH}_{3} ;>\mathrm{CO}_{2}>\mathrm{O}_{2}>\mathrm{H}_{2} \mathrm{C}>\mathrm{CH}_{4}$. Dujų daugiau sorbuoja toks dirvožemis, kuriame daugiau humuso, geležies hidroksido. Pakilus temperatūrai, dirvožemio dujų sorbcijos galia sumažèja (Batjes, 1996, Bennema 1974). 
Vanduo dirvožemyje tirpina dujas, kurių tirpumas padidèja sumažèjus vandens temperatūrai ir atvirkščiai. Jei padidèja dujų slègis, tai jų tirpumas irgi padidèja. Jei įdruskejjusių dirvožemių tirpalo koncentracija padideja, tai dujų juose sumažèja (Анспок 1991).

Dirvožemio oro sudètis nuolat kinta dèl dujų apytakos tarp atmosferos, vykstančios dèl paros ir metų temperatūros svyravimo, vejo stiprumo ir krypties, vandens filtracijos ir kitų reiškinių. Dirvožemio oro sudèties kitimas priklauso ir nuo biocheminių procesų. Dujų apytaka tarp dirvožemio ir atmosferos vyksta dèl difuzijos, dèl atmosferos slègio kitimo, dèl gruntinio vandens gylio kitimo. Dieną, kai dirvožemis išyla, oro tūris padideja ir dalis jo su $\mathrm{CO}_{2}$ iš dirvožemio išeina, o nakti, atvirkščiai, atmosferos oras, kuriame daug deguonies, skverbiasi i dirvožemi. Oro apytaka vyksta nekapiliarinėmis poromis (Kutzbach 2007).

Dirvožemio oro kitimas priklauso nuo augalų, gamtinių sąlygų, i dirvožemi iterptų trąšų ir t. t. Anglies dioksido dirvožemio ore daugiau vasarą ir mažiau žiemą. Dèl dirvožemio per didelio drègnumo pavasarị ir vasaros pradžioje vystosi anaerobiniai procesai. Jie gali vykti ir dèl didelès lietinimo normos. Dél tos priežasties velëniniuose pievų dirvožemiuose yra daugiau $\mathrm{CO}_{2}$ negu didesnių žemių dirvožemiuose (Feizienė 2008, Batjes, 1999).

Padaugejjus anglies dioksido dirvožemyje, kinta ir jo reakcija. Trūkstant dirvožemyje deguonies, vystosi denitrifikacijos procesai, susidaro kenksmingos $\mathrm{CH}_{4}, \mathrm{H}_{2} \mathrm{~S}$ ir kitos dujos. Padaugejjus anglies rūgšties dirvožemio tirpale, padidèja ir vandenilio jonų koncentracija, todèl padideja $\mathrm{CaCO}_{3}$ ir kitų druskų tirpumas.

Dirvožemio oro imlumas (talpumas) priklauso nuo jų poringumo ir drégnumo. Sauso dirvožemio oro imlumas būna didžiausias, nes jo visas poras užima oras. Dirvožemio didžiausias oro imlumas lygus poringumui. Lauko oro imlumas - kintamas dydis, priklausąs nuo gamtinių ir agromelioracinių sąlygų, labiausiai nuo dirvožemio drègnumo. Dirvožemyje vandens daugèjant, mažèja oro, ir atvirkščiai (Ingram 2001).

\subsection{Mikroorganizmų vaidmuo dirvožemio susidarymui}

Dirvožemio mikroorganizmų vaidmuo yra didžiulis. Jie i aplinką išskiria fermentus ir kitas veikliąsias medžiagas. Jos sukelia chemines reakcijas - organinius junginius paverčia mineraliniais. Šitaip yra skaidomos augalinès ir gyvūninès dirvožemio liekanos. Jos paverčiamos azoto, fosforo, kalcio, sieros ir kitais junginiais, kuriuos savo kūno statybai (mineralinè mityba) naudoja aukštesnieji augalai (Jankevičius, Liužinas, 2007). 
Organizmai uolienas ardo mechaniškai ir chemiškai. Aukštesnieji augalai uolienas ardo chemiškai, per šaknis išskirdami anglies dioksida, organines rūgštis, kurios, veikdamos uolienų mineralus, taip jas ardo (Tripolskaja 2005).

Mikroorganizmams priskiriami pirmuonys, dumbliai, kerpès, grybai ir bakterijos.

Pirmuonys (Protozoa). Dirvoje plačiai išplitę pirmuonys priskirti šakniakojų, žiuželinių, blakstienotujų klasėms. Pirmuonių daugiausiai randama šlapiuose ir užmirkusiose dirvose, bet jų yra ir normalaus drègnumo žemès plotuose. Pirmuonys minta bakterijomis, tai apie jų reikšmę dirvožemio derlingumui nèra vieningos nuomonès. Pirmuonių gausumas nemažina bakterijų skaičiaus, nes jos labai greitai dauginasi. Be to, žuvę pirmuonys tampa geru maistu bakterijomis ir taip sudaro sąlygas joms daugintis ir gyventi (Eitminavičiūte 1997, Janušienè 1992, Aplalia 1982, Гуев 1989).

Pirmuonių, ypač infuzorijų veiklą reikètų vertinti teigiamai, nes virškindami netirpius organinius junginius katu su mikroorganizmais dirvožemyje greitina medžiagų apytaką.

Dumbliai kaip fototrofai, labiausiai išplitę dirvos paviršiuje ir iki $30 \mathrm{~cm}$ gylyje. Jų skaičius $1 \mathrm{~g}$ dirbamos žemés paviršiuje gali siekti iki 100 tūkst. Tai daugiausiai žaliadumbliai, mesvadumbliai ir diatominiai dumbliai, o šiltesnio klimato dirvožemiuose dar ir gleivadumbliai (Eitminavičiūtė 1997, Danilevičius 1977).

Dumblių reikšmė dirvos biocheminiams procesams yra labai didelè. Fotosintezès dèka jie anglies dioksidą paverčia jų sintetinamais organiniais junginiais, kurie dumbliams žuvus dirvą prturtina organinėmis medžiagomis, palyginti greitai mineralizuojasi ir sudaro sąlygas mikroorganizmams, tarp jų - azotą fiksuojančioms bakterijoms, daugintis ir egzistuoti. Dèl dumblių vyksta fotosintezè, dirva praturtinama ne tik organinèmis medžiagomis, bet ir deguonimi, reikalingu aerobiniams mikroorganizmams kvėpuoti. Be to, kai kurie dumbliai gali isisavinti laisvaji atmosferos azotą (Janušienè 1994, Бабров 1981).

Daugiausiai dumblių dirvožemyje būna pavasarị, mažiausiai žiemą.

Simbiozeje su chemotrofinèmis bakterijomis dumbliai gali gyventi ant kietu uolų, pagreitina jų dūlèjimą.

Kerpès gali gyventi ir daugintis ant plikų uolų, nes geba siurbti iš jų mineralines medžiagas ir jomis maitintis. Kadangi dauguma kerpių turi tenkintis atmosferos vandeniu, tai jų daugiausia yra drègnesnio klimato šalyse. Ant uolų palaipsniui formuoja dirvožemio sluoksni, kuriame kaupiasi azotas, fosforas, kalis, kalcis ir kiti elementai, sudarantys sąlygas gyventi samanoms, o veliau ir aukštesniems augalams (Eitminavičiūtè 1997, Janušienė 1994). Bakterijų reikšmè nepaprastai didelè žmogaus gyvenime ir visoje gamtoje. Dauguma jų atlieka skaidytojų „darbą“ - nuokritų organinę medžiagą suskaido iki mineralinių medžiagų, kurias jau gali pasisavinti organinių medžiagų gamintojai - augalai. Bak- 
terijos yra ne tik mūsų planetos „sanitarai“, bet ir daugiausia prisideda prie derlingo dirvožemio susidarymo. Pūdydamos ir skaidydamos daugybę tonų ivvairiausių nuokritų, organizmų lavonų, ivvairių organinių atliekų, dirvožemyje pagausina puvenų (humuso). Kai kurios bakerijos dalyvauja azoto junginių apytakos cikle, kuris be jų veiklos nebūtu imanomas (Danilevičius 1977, Eitminavičiūtė 1997, Мипчинк 1979).

Dirvožemyje vyksta nenutrūstamas vadinamasis mažosios biologinès medžiagų apykaitos ratas, kuriame mikroorganizmai skaido augalų ir gyvūnų liekanas i paprastesnius organinius darinius ir mineralinius komponentus, kurie biologiškai sujungiami ir vèl patenka ị naują šios apykaitos ciklą. Mikroorganizmai naudoja anglies junginius energijai ir mitybai, o azotas yra būtinas DNR baltymu sintezei ir fermentams. Pasisavindami vieną dalį azoto vidutiniškai jie sunaudoja aštuonias dalis anglies. Tik trečdali pasisavintos anglies mikroorganizmai panaudoja kūno statybai, likusi dalis išskiriama $\mathrm{CO}_{2}$ pavidalo. Dèl to maistui ir energijai jiems reikia 24 dalių anglies vienai daliai azoto. Tai sąlygoja du labai svarbius dirvodaros biologinius reiškinius (Eitminavičiūtė 1997):

1) jeigu organinèse liekanose $\mathrm{C}: \mathrm{N}$ kiekių santykis $>25$, mikroorganizmai skaidys ir naudos dirvožemio azotą savosioms reikmėms patenkinti,

2) jeigu mikroorganizmai stokos azoto, jie letai skaidys organines liekanas, todèl nedaug mineralinio azoto pateks i dirvožemio sorbuojamaji kompleksą ir dirvožemio tirpalą.

Dirvožemyje keičiantis organinès ir mineralinès medžiagos kiekiui, keičiasi ir mikroorganizmų kiekis bei rūšinè sudètis. Mažosios biologinès medžiagu apykaitos metu dirvožemyje vyksta azoto išlaisvinimas ir sujungimas.

Esant storesnei dirvožemio paklotei, apatiniai sluoksniai būna labiau perpuvę negu viršutiniai. Skiriasi ir tuose sluoksniuose gyvenančių organizmų sudètis. Pagal dirvožemio genetinius horizontus:

$O 1$ - sluoksnyje gyvena paklotiniai gyvūnai ir mikroorganizmai. Tarp mikroorganizmų dominuoja epifitai, patekę i paklotę su krintančiais lapais. Gausios nesporinès bakterijos ir grybai. Mikroartropodai gausūs, dominuoja oribatidinių erkių ir kolembolų paklotinès rūšys. Šiame sluoksnyje skaidosi angliavandeniai, pektinai ir baltymai.

$O 2$ - sluoksnyje mikroorganizmų yra gausiausiai, tai rodo kvejpavimo intensyvumas. Dominuoja bazidiomicetai ir celiuliozès skaidytojai Chaetonium, Trichoderma, Mycogone, sacharolitinio komplekso atstovai: mielès ir grybai Mucor . Paplitusios ir bakterijos. Šiame sluoksnyje dominuoja oribatidinès erkès ir kolembolos. A1 sluoksnyje toliau skaidomos organinès medžiagos: celiuliozė, chitinas, ligninas, vyksta humusinių medžiagų sintezè.

O3 - sluoksnyje pastebimai mažèja dirvožemio kvėpavimo intensyvumas. Pagrindinè priežastis - grybų komplekso sumažejjimas. Dominuoja aktinomicetai 
ir sporinès bakterijos. Tarp mikroartropodų dominuoja humusinio sluoksnio gyventojai ir makrofauna, ypač sliekai, kaprolitai. Mineralizacijos procesai baigiasi. Šiame sluoksnyje vyksta sudètingesnių humusinių junginių sintezè.

Mikroartropodų ir mikroorganizmų gausumas labai sumažeja baigiantis humusiniam ir prasidedant mineraliniam dirvožemio sluoksniui. Mikrofaunoje dominuoja dirvožeminès ir gilesnių sluoksnių rūšys (Eitminavičiūtė 1997).

Augalinès ir gyvūninès liekanos skaidomos dirvožemio paviršiuje (lapai, žolè, negyvi gyvūnai, grybų vaisiakūniai) ir gilesniuose jo sluoksniuose (šaknys, svogūnai, grybiena, gumbai ir pan.). Miške iš nukritusių lapų formuojasi miško paklote, iš nudžiūvusių žolių - velèna. Mineralizacijos pobūdis ir intensyvumas priklauso nuo trijų veiksnių - liekanų sudèties, hidroterminio režimo, destruktorių komplekso. Organinių liekanų destrukcijos procesas gali vykti trimis kryptimis: 1) visiška mineralizacija, 2) humifikacija, 3) ne visai suskaidytų organinių liekanų konservacija (Čaikauskas 1985).

Mineralizacijos procese išlaisvinami augalinejje biomaseje sutelkti cheminiai elementai, sudarantys sąlygas nenutrūkstamai medžiagų apykaitai, vykstančiai ekosistemoje.

Labai svarbi grybų reikšmė mineralų dūlëjimo procese. Skaldant augalines liekanas grybai utilizuoja visus pagrindinius augalo ląstelès komponentus - pradedant paprastais angliavandeniais ir baltymais ir baigiant sunkiai įsisavinamais lasteliena ir celiulioze. Šių medžiagų skilimo metu susidaro įvairios Krebso ciklo rūgštys (rūgštynių, citrinų, obuolių ir kitos), ligninui skylant rezultate - vanilinè, paraoksibenzoinè ir kitos rūgštys. Grybų medžiagu apytakos savybė - kad šios rūgštys toliau neịsavinamos, o kaupiasi dirvožemyje. Tos rūgštys plaunamos gilyn, veikia mineralines uolienas ir skatina jų dūlèjimą (Berger 1996).

Jei dirvožemio organinèse liekanose $\mathrm{C}: \mathrm{N}$ kiekių santykis nedidelis (apie 4), jos intensyviai skaidomos, išsiskiria $\mathrm{NH}_{3}$, bet dauguma mikroorganizmų sunaudoto mineralinio azoto patenka į humifikaciją jei $\mathrm{C}: \mathrm{N}$ kiekių santykis apie 20-25, išlaisvinama daug mineralinio azoto, o jei C : N kiekių santykis 80-100, vyksta biologinis azoto sujungimas. Kalcinguose dirvožemiuose $\mathrm{C}$ : N kiekių santykis yra nedidelis, rūgščiuose - net iki 30, juos pakalkinus, lieka apie 12. Intensyvūs mikrobiologiniai procesai dirvožemyje gali būti naudingi, tačiau greitas organinès medžiagos skilimas, nitratinio azoto kaupimasis, jo išsiplovimas i gruntinį vandeni, aktyvi denitrifikacija ir azoto išgaravimas sukelia dirvožemio taršą ir degradavimą. Vakarų šalyse mokslininkai nustatė azoto sujungimo skirtumus dèl nevienodo $\mathrm{C}$ : N kiekių santykio miežių šiauduose priklausomai nuo iterpimo vietos, laiko ir auginimo technologijos. Atrodo, kad skirtumai yra susiję pirmiausia su mineralinio azoto buvimu. Dirvose, kuriose auginami eraičinai ar liucernos aparti šiaudai sujungia mažiau azoto nei paviršiuje palikti šiaudai. Tai tikriausiai yra todèl, kad tarp augalų šaknų ir liekanose esančių skaidytojų vyksta konkurencija dèl esančio azoto. Azoto sujungimas sutampa su 
pradiniu grybų micelio įaugimu i pūvančius miežių šiaudus. Nustatyta, kad grybų nauda azoto sujungimui yra maždaug tris su puse karto didesnè nei bakterijų nauda, nors dauguma sujungto azoto yra šalutiniuose mikroorganizmų produktuose, o ne jų biomasèje (Grigaliūnienè 2005, Eitminavičiūtè 1997).

\subsection{Lietuvos dirvožemių humusingumas}

Organinès medžiagos kiekio dirvožemyje nustatymo laboratoriniai metodai yra palyginti brangūs ir sudètingi. Dèl šių priežasčių detalių ir sistemingų Lietuvos dirvožemių humusingumo tyrimų, kaip rūgštumo, fosforingumo ir kalingumo, daryta nebuvo. Tik 1982-1990 metais LŽI Agrocheminių tyrimų centras pagal vieningą metodiką atliko platesnius humuso kiekio tyrimus 37 rajonų ūkiuose, o septynių rajonų buvo tirti 2-4 ūkių dirvožemiai (Lietuvos dirvožemiai 2001).

1.2. lentelè. Dirvožemių humusingumo vertinimas (Lietuvos dirvožemiai 2001)

Table 1.2. Evaluation of soil humus content (Lietuvos dirvožemiai 2001)

\begin{tabular}{|l|c|c|c|}
\hline \multirow{2}{*}{$\begin{array}{c}\text { Dirvožemio humusingu- } \\
\text { mas }\end{array}$} & \multicolumn{3}{|c|}{ Humusas \% } \\
\cline { 2 - 4 } & smèliai & $\begin{array}{c}\text { priesmèliai, prie- } \\
\text { moliai, moliai }\end{array}$ & $\begin{array}{c}\text { miško dirvože- } \\
\text { mis }\end{array}$ \\
\hline Labai mažo humusingumo & Mažiau kaip 0,5 & Mažiau kaip 1,0 & Mažiau kaip 1,0 \\
\hline Mažo humusingumo & $0,6-1,5$ & $1,1-2,0$ & $1,1-2,0$ \\
\hline Vidutinio humusingumo & $1,6-2,5$ & $2,1-3,0$ & $2,1-4,0$ \\
\hline Humusingi & $2,6-3,5$ & $3,1-4,0$ & $4,1-6,0$ \\
\hline Didelio humusingumo & Daugiau kaip 3,5 & Daugiau kaip 4,0 & Daugiau kaip 6,0 \\
\hline
\end{tabular}

Lietuvos dirvožemiai pagal humuso kiekị suskirstyti į 5 grupes (1.2. lentelè). Visapusiška tyrimų duomenų analizè rodo, kad Lietuvos dirvožemiuose humuso kiekis labiausiai priklauso nuo jo imirkimo laipsnio, granuliometrinès sudèties ir sukultūrinimo.

Rytų bei Pietryčių Lietuvoje humuso kiekis dirvožemyje labai ịvairuoja, bet daugeliu atvejų jo yra nedaug ir skiriasi pagal dirvožemių granuliometrinę sudètị: smėliuose dažniausiai jo yra $0,5-1,2 \%$, priesmėliuose $1,3-1,5 \%$, priemoliuose $1,5-1,9 \%$, o moliuose $2,0-3,5 \%$. Mažiausiai humuso yra vidutiniškai bei stipriai erozijos paveiktuose dirvožemiuose $(0,4-1,2 \%)$. Vakarų Lietuvoje panašių pagal kilmę dirvožemių humusingumas dèl nevienodų klimatinių sąlygų (didesnis kritulių kiekis ir vidutiné metiné temperatūra), dirvodarinių uolienų sudèties, skirtingo reljefo yra didesnis. Išplautžemiuose, priklausomai nuo 
granuliometrinès sudèties, humuso būna 1,0-2,8\%, balkšvažemiuose - 2,5$4,0 \%$. Vidurio Lietuvos žemumoje dirvožemiai susiformavę ant karbonatinių ivairios granuliometrinès sudèties dirvodarinių uolienų, organinè medžiaga kaupiasi intensyviau, todèl šios zonos dirvožemiai yra humusingesni už kitu gamtinių regionų dirvožemius (Lietuvos dirvožemiai 2001).

Apibendrinus visų rajonų humusingumo tyrimų duomenis nustatyta, kad Lietuvoje labai mažo humusingumo dirvožemių yra 1,3\%, mažo humusingumo $-32,9 \%$, vidutiniško humusingumo $-37,2 \%$, humusingu $-17,7 \%$ ir labai humusingų $-11,4 \%$. Atskirų rajonų dirvožemių humusingumas labai skiriasi. Labai daug mažo ir labai mažo humusingumo dirvožemiu (70-90\%) yra Zarasų, Molètu̧, Lazdijų, Trakų, Utenos, Varènos rajonuose. Vidurio Lietuvoje mažo humusingumo dirvožemių yra tik 17,3\% (Buivydaite 2001, Lietuvos dirvožemiai 2001, Bakšiènè 2004).

Galima spèlioti, kodèl dabartiniu metu Lietuvos dirvožemių humusingumas dar labiau diferencijavosi, daugelyje ūkių sumažejo. Tokius procesus sąlygoja pasėlių struktūros pokyčiai, gyvuliu skaičiaus sumažèjimas, dirvožemių rūgštèjimas ir kitos priežastys. Dèl siauresnès ūkių specializacijos rinkos ekonomikos sąlygomis plinta specializuotos javų ar kitų augalų sejomainos, sejjomainose nebeauginamos daugiametès žolès, nes, sumažèjus gyvulių skaičiui, tapo mažiau reikalingi žoliniai pašarai, ne visi ūkininkai laiko pakankamai gyvulių, kad sukauptų reikalingą laukams tręšti mèšlo kiekị. Sumažejus gyvulių skaičiui, dalis šiaudų tapo nereikalingi kaip kraikas, todèl plinta laukų tręšimas šiaudais, kurie, neprisilaikant tręšimo rekomendacijų, gali suaktyvinti organinès medžiagos mineralizaciją arba padidinti dirvožemio azoto biologinę imobilizaciją bei daryti neigiamą itaką humuso akumuliacijos dirvožemyje procesams (Lietuvos dirvožemiai 2001, Bieliauskas 1985, Birietienè 1984).

\subsection{0. Žemdirbystès poveikis dirvožemio elementu balansui ir itaka klimato kaitai}

Sumažèjus dirvožemio organinès anglies kiekiui, sumažeja jo gebejjimas sugerti vandeni, o tai paskatina nuotéki bei eroziją. Erozija taip pat mažina organinių medžiagų kiekỉ, nes nuplaunamas trąšus viršutinis dirvos sluoksnis. Pusiau sausringo oro sąlygomis tai gali nulemti dykumèjimą (Baldock 1999).

Numatoma, kad pasaulinis atšilimas pagreitins organinių medžiagų puvimą, kurio metu išsiskiria daugiau $\mathrm{CO}_{2}$ ir greičiau vyksta klimato pokyčiai. Dèl to dykumejjimas gali pasislinkti i šiaurę. Iš anglies atsargų, palaikomų šalto oro ir drègno klimato sąlygų, šiltesnèmis sąlygomis i atmosferą išsiskirs daug $\mathrm{CO}_{2}$ ir metano $\left(\mathrm{CH}_{4}\right)$. Taip atsitinka ir tada, kai nusausinamos pelkès arba kasamos durpés. Pavyzdžiui, nuolat sausinant likusius Europos durpynus, kasmet išsiskirtų 
30 milijonų tonų anglies dioksido - tiek pat, kiek iš dar 40 milijonų automobilių Europos keliuose (Olsen 2002, Beliauskas 1976).

Dirvožemio organinès anglies kaitos sąsajos su jo erozija. Dirvožemio organinè anglis veikia daugelị dirvožemio savybių: dirvožemio drègmės imlumą, dirvožemio bazingumą, dirvožemio maisto medžiagu prieinamumą, dirvožemio struktūringumą, struktūros patvarumą, dirvožemio oro ir šilumos savybes. Dirvožemio organinė anglis pripažistama dirvožemio kokybės indikatoriumi ir biosferos ekologinès pusiausvyros bei stabilumo rodikliu, turinčiu itakos klimato kaitai Žemèje. Dirvožemio organinè anglis, kaip pagrindinis dirvožemio komponentas, susideda iš mikroorganizmų ląsteliu, ivvairaus suirimo laipsnio augalų ir gyvūnų liekanu̧, stabilaus ,humuso“ (sintezuoto iš organinių liekanų) ir iš labai karbonizuotų medžio anglies, grafito ar akmens anglies (Jankauskas 2003) (1.4 pav.). Irstant įvairioms žemdirbystės atliekomis, susidarančiomis nuimant derlių, bei organinemis trąšomis vyksta humifikacija, kurios metu tik iki $20 \%$ sukaupiama dirvožemyje. Dalis medžiagų yra nuplaunamos veikiant vandens erozijai. Taip pat dalis organinių medžiagu yra pernešamą veikiant ir vejjo erozijai. Veikiant dirvožemio eroziniams procesams iš ariamo lauko pasišalina i vandens telkinius arba pašlaites iki 0,6 Gt dirvožemio organinès anglies. Dalis šios anglies virsta i anglies dioksido, o anaerobinemis sąlygomis iki metano (Bukantis 2001, Богдезич 2000, Богдевпч 1998).

Palyginus su žemès ūkio naudmenomis, pušynuose dèl miško paklotès mineralizacijos išplautžemių viršutiniame $5 \mathrm{~cm}$ mineraliniame sluoksnyje kaupiasi $\mathrm{C}$ ir N, lečiau vyksta organinès anglies junginių skaidymas. Apskaičiuota, kad išplautžemiuose (iki $1 \mathrm{~m}$ gylio) C sankaupos pušynuose, dobilu žolyne ir vasariniuose rapsuose iš esmès nesiskyrè ir sudare $61-75 \mathrm{t} / \mathrm{ha}$. Tik dèl miško paklotės susikaupimo išplaušžemių $\mathrm{N}$ sankaupos pušynuose yra 13-18 kartų didesnès (82-98 kg/ha) negu žemès ukio naudmenose (apie 5-6 kg/ha). Tačiau ariamame Ap horizonte tiek pušynuose, tiek žemès ūkio augalų pasèliuose $\mathrm{N}$ sankaupos ivairuoja panašiose, 2,5-3,3 kg/ha, ribose (Jankauskas 2003).

Išplautžemių vidutinis suminis mikrofloros gausumas pušynuose buvo vidutiniškai 7-33\% mažesnis negu dobilų pasèliuose, tačiau 27-39\% didesnis negu rugiuose, o palyginus su lubinų pasèliais, iš esmès nesiskyrè. Mikrofloros gausumas ant modifikuotos lignino monomerais mitybinių terpiug daugeliu atveju, buvo didesnis žemès ūkio naudmenose. Tai parodo, kad palyginus su pušynais, žemės ūkio naudmenose intensyviau kaupiasi organinè C. Tačiau miškų išplautžemiuose dèl to, kad intensyviau kaupiasi organine $\mathrm{C}$, žymiai intensyviau mikroflorai kvejpuojant, gali būti iškiriami didesni $\mathrm{CO}_{2}$ kiekiai (Kiburys 1995, Bakšienè 2006, Račinskas 1990). 


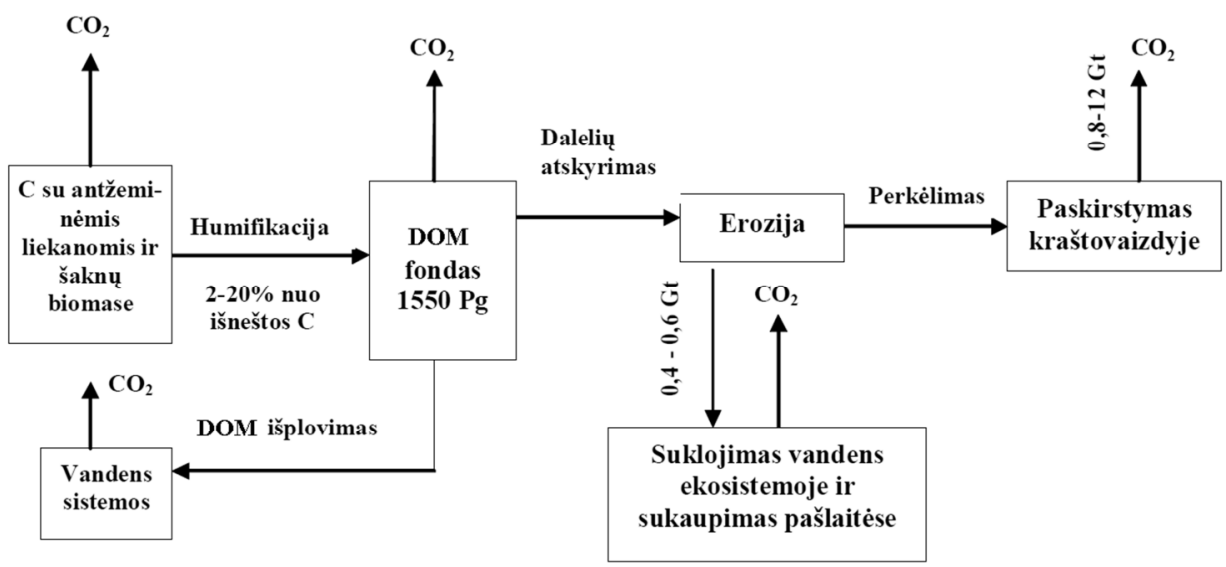

1.4. Pav. Procesai, veikiantys dirvožemio organinès medžiagos (DOM) dinamika. Rodyklès i viršų rodo $\mathrm{CO}_{2}$ emisiją (išgaravima) i atmosferą. Anglis dar gali išgaruoti $\mathrm{CH} 4$ forma, esant anaerobinèms sąlygoms ar iš gerai drenuotų dirvų (Lal 2004)

Fig. 1.4. Processes affecting soil organic matter (DOM) dynamics. Up Arrow shows the $\mathrm{CO}_{2}$ emissions (evaporation) into the atmosphere. Coal can not evaporate in the form of $\mathrm{CH}_{4}$, with anaerobic conditions or in well-drained soils (Lal 2004)

Suarus dirvą ir pradejus joje auginti žemès ūkio augalus, itin pakinta dirvožemio maisto medžiagų balanso pobūdis dèl šių priežasčių: 1) pakinta biologinès apykaitos parametrai, kai natūrali biocenoze pakeičiama dirbtine agrocenoze. Dèl to dirvožemis gauna daug mažiau anglies, sorbuotos augalų iš atmosferos, iš dirvožemio su derliumi išnešama daug $\mathrm{N}, \mathrm{P}, \mathrm{K}, \mathrm{Ca}, \mathrm{Mg}, \mathrm{S}$ ir kitų biofilinių elementų, Šalto ir vidutinio klimato miškų ekosistemose kasmet i dirvožemi patenka 8-12 $\mathrm{t} \mathrm{ha}^{-1}$ nuokritų ir virtèlių, pievu bendrijose $-20 \mathrm{t} \mathrm{ha}^{-1}$, agrocenozèse tik 3-8 $\mathrm{t} \mathrm{ha}^{-1}$; 2) i dirvožemi įterpiami biofiliniai elementai su trąšomis ir meliorantais, o drèkinamoje žemdirbysteje su laistomais ìvairios mineralizacijos vandenimis; 3) ariami dirvožemiai netenka dalies medžiagų dẻl plokštuminès ir linijinès (griovų) vandeninès erozijos; 4) pirmaisiais dešimtmečiais po suarimo dirvožemis netenka didelès dalies anglies dèl miško paklotės, stepès veltinio ir humuso intensyvesnès mineralizacijos. Taip i atmosfera papildomai patenka anglies $\mathrm{CO}_{2}$ forma; 5) nusausinus ar po ilgo lietinimo pakinta dirvožemio, drègmès, kartu ir visų cheminių elementų balansas (Bukantis 2001, Tylienè 1974).

Visų šiu pokyčių mastas būna skirtingas suarus stepę ar miško kirtavietę. Pavyzdžiui, jeigu iškirsto spygliuočių ar plačialapių miško vietoje imtume verstis vidutinio intensyvumo žemdirbyste, tai kasmet susintetintume 1,5-2 kartus daugiau organinių medžiagų. Suarus stepę, i apytaką isijungtu 1,5 karto mažiau 
anglies. Tačiau ir vienu, ir kitu atveju biogeninès anglies su augalinėmis liekanomis į dirvožemi patektų mažiau, nes didesnè dalis žemès ūkio augalų susintetintos organinès medžiagos (60-70\%) būtų išvežama su derliumi (Jones 2005, Lal 2004). Taip staiga sumažejjus kasmet patenkančio i dirvožemi organinės medžiagos kiekio, suprantama, jame kaupiasi ir mažiau humuso. Be to, ši mažejimą lemia ir pakitusios organinès medžiagos skaidymosi sąlygos bei mikroorganizmų rūšinè sudètis (Soil Atlas... 2005).

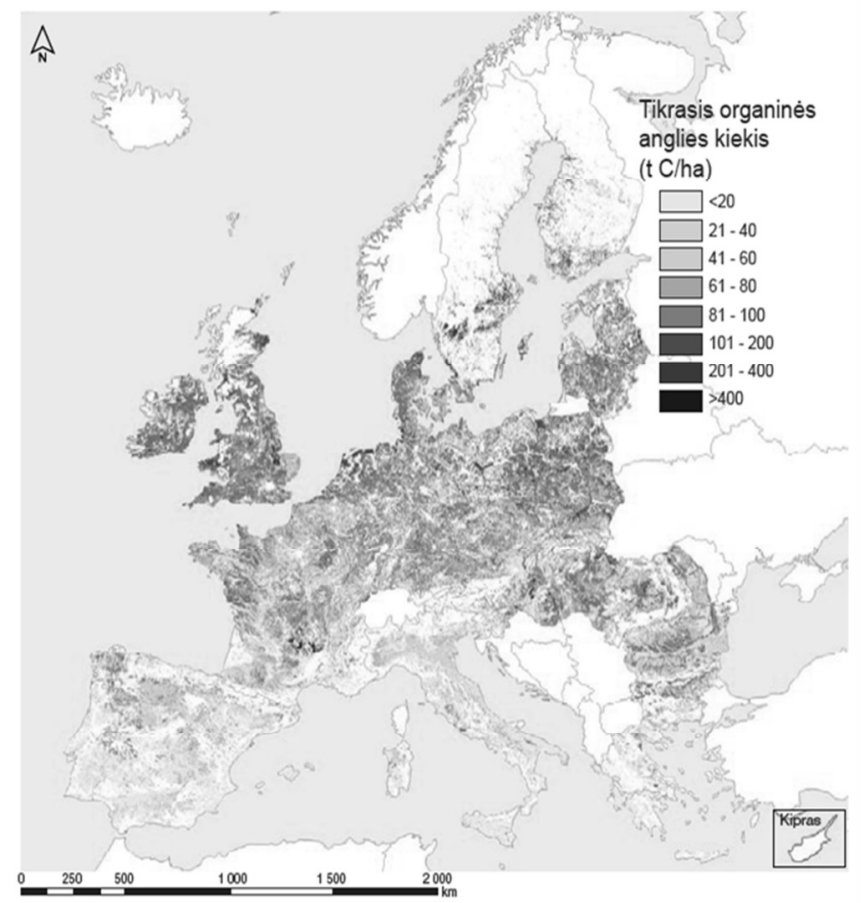

1.5. pav. Žemèlapis, kuriame parodytas tikrasis organinès anglies kiekis 27 valstybių nariu žemès ūkiui naudojamuose dirvožemiuose (Lal 2004)

Fig. 1.5. A map showing the actual organic carbon content of 27 Member States of the agricultural soils (Lal 2004)

Didesnè dalis humuso suyra lengvuose dirvožemiuose, mažesnè sunkiuose. Suirusi dalis humuso priklauso ir nuo žemès dirbimo intensyvumo, t. y. nuo įvairiu augalų auginimo technologijos, sèjomainos ir pasèlių struktūros (1.5. pav.). Žvelgiant 1.5 pav. matyti, kad pietų šalyse esantis organinès anglies kiekis ariamame dirvožemyje siekia $<20 \mathrm{t} \mathrm{C/ha}$. Tik vidurio Europoje organinès anglies kiekis ariamame dirvožemyje siekia nuo 61 iki 200 t C/ha. Humuso mažejjimas 
pastebimas ir derlingiausiuose Rusijos juodžemiuose (Chernozems), kuriuose humuso kiekis, praejjus 100 metų nuo jų naudojimo žemdirbystèje, sumažejjo nuo 20-30 iki 56-69\%. pirminio kiekio. Toks neigiamas humuso balansas būdingas ne tik ariamiems juodžemiams, bet ir mūsų zonos vyraujantiems išplautžemiams (Luvisols), jeigu nesiimama reikiamų priemonių (IPCC 2001, Braukyla 1984, Kogut 1998).

Mūsų dirvožemiuose auginant daugiametes žoles, per metus suyra apie 0,7$0,9 \%$, auginant bulves arba cukrinius runkelius $-4,1-4,5 \%$., o vidutiniškai apie $2-2,7 \%$. dirvožemyje esamo humuso. Vidutiniškai iš ivvairių dirvožemių, auginant skirtingus žemès ūkio augalus, kasmet su derliumi iš 1 ha netenkama 65-285 kg azoto $(\mathrm{N}), 26-27 \mathrm{~kg}$ fosforo $\left(\mathrm{P}_{2} \mathrm{O}_{5}\right)$ ir 42-235 kg kalio $\left(\mathrm{K}_{2} \mathrm{O}\right)$. Be to, išvežama ir dešimtys bei šimtai kilogramų iš ha tokių elementų - biofilų, kaip $\mathrm{Ca}, \mathrm{Mg}, \mathrm{S}$. Suprantama, šiuos nuostolius reikia kompensuoti tręšiant dirvožemi organinèmis ir mineralinèmis trąšomis (Bundinienè 1998).

Laikoma, kad normalaus drègnumo (nusausintuose) Lietuvos žemès ūkio naudmenų mineraliniuose dirvožemiuose per metus vidutiniškai suyra (mineralizuojasi) apie $6-8 \mathrm{t} \mathrm{ha}^{-1}$ humuso (vidutinis svertinis humuso kiekis - apie $2 \%$.). Humuso netenkama ir dèl vandeninès bei dirvožemio vèjinès erozijos. Todèl, kultūrinant dirvožemius pirmiausia svarbu išlaikyti teigiamą arba bent nulini humuso balansa. Tai šiuolaikineje intensyviojoje žemdirbysteje pasiekiama šiomis agrotechnikos priemonemis: organinių trąšu iterpimas, sejjomaina su daugiametėmis ankštinèmis žolèmis, sideracinių ir tarpinių augalų issejjimas, augalų derlingumo didinimas siekiant ne tik gauti daugiau produkcijos, bet ir palikti dirvožemyje daugiau augalinių liekanų, antierozinių priemonių taikyma (Organic agriculture... 2002, Bundinienè 1998).

\subsection{Miško reikšmẻ bendrosios anglies didinimui dirvožemyje}

Tiriant augalinės biomasès kaupimąsi laiko atžvilgiu, irodyta kad visu poledynmečiu Baltijos regione, drauge ir Lietuvoje, biomasès kaupimasis smarkiai kito. Kito ir gamtinis regioninès sistemos tvarumas. Lietuvos teritorijoje regioninè sistema geriausią tvarumo rodiklį turejjo maždaug prieš 6 tūkst. metų atlantinèje chronozonoje, kai čia vyravo plačialapiai miškai. Tuomet mūsų teritorijoje būta $320 \mathrm{t} \mathrm{ha}^{-1}$ fitomasès ir beveik $12 \mathrm{t} \mathrm{ha}^{-1}$ kasmetinio prieaugio. Stojus subborealinei chronozonai ir ịsivyravus spygliuočių miškams, fitomasès mažèjo. Kartu silpnèjo ir regioninès sistemos ekologinis tvarumas, kuris savo minimumą pasieke šio amžiaus viduryje, kai fitomasès sumažèjo iki $34 \mathrm{t} \mathrm{ha}^{-1}$, o jos prieaugis - iki 7,2 t ha $^{-1}$ (Bukantis 2001, Hagedorn 2001). 
Naudojantis analogų metodu ir tiesiogiai apskaičiuojant fitomasę, pagal to meto temperatūrą ir kritulių kiekį mokslininkai: T. Bumblauskis, V. Mikšys, L. Kairiūkštis, A. Raguotis, J. Tamošaitis, P. Matulionio nustatė, kad per visą poledynmeti (maždaug 13200 metu) nuo arktinès iki dabartinès - antrosios pusès subatlantinès chronozonos Lietuvos teritorijoje vidutiniškai 1 ha būta 180 t fitomasès ir 7,1 t kasmetinio prieaugio. Mažiausias prieaugis $-0,03 \mathrm{t} \mathrm{ha}^{-1}-$ buvo esant arktinei ir didžiausias $-11,9 \mathrm{t} \mathrm{ha}^{-1}$ - esant atlantinei chronozonai. Dabar, antrojoje subatlantinès chronozonos puseje, jis lygus 8,3 $\mathrm{t} \mathrm{ha}^{-1}$ (Jankauskas 2004, 1996).

Taigi Lietuvos teritorijoje per visą poledynmeti kaip metinių prieaugių suma buvo sukaupta apie 662,6 mlrd. $t$ absoliučiai sausos organinès medžiagos. Analizuojant fitomasès ir prieaugio mažejimą nuo $800 \mathrm{~m}$. iki $1950 \mathrm{~m}$., kai fitomasé sumažèjo nuo 180 iki $33,4 \mathrm{t} \mathrm{ha}^{-1}$, o prieaugis nuo 9,0 iki 7,5 $\mathrm{t} \mathrm{ha}^{-1}$, pasirodè, kad fitomasès ir prieaugio mažèjimą praeityje lèmé klimato sąlygų kaita. Tik per ši tūkstantmeti ryškiai pasireiškẻ žmogaus veikla naikinant miškus ir keičiant žemès naudojimo būdą. Pažymètina, kad miškų plotai mažejo ne tik dèl miškų "lydymo", išdeginant miškingas teritorijas ir plečiant laukus, bet ir dèl plotų be jokios augalijos (gyvenvietès, miestai, keliai ir t.t.) didejjimo. Visa tai mažino antropogeninès taršos natūralaus apsivalymo galimybes ir silpnino visų teritorijoje esančių gyvujų sistemų ekologinį tvarumą (Partyka 2010, Kiburys 1995).

Sumažejęs krašto miškingumas atpalaidavo ir fizinių veiksnių, ardančių regioninès sistemos tvarumą, poveikị. Ryškiai pasireiške dirvų erozija. Dažni vejjai sudare prielaidas intensyviam dirvožemių nupustymui, ypač Pajūrio žemumoje, kur kasmet vidutiniškai netenkama 3-10 t ha ${ }^{-1}$ humusingesnio dirvožemio.

Regioninès sistemos savaimini tvarumą daugiau palaikè tik ta aplinkybè, kad teritorijoje poledynmečiu buvo susikaupę dideli negyvosios organinès medžiagos kiekiai, daug kartų didesni už dabartinès augalų fitomasès išteklius. Bet ir fitomasès ištekliai seko neadekvačiai jų naudojimui. Ryškus to pavyzdys durpynai. Juose mažèjo organinès medžiagos dèl pelkių sausinimo, durpių ir humuso mineralizacijos. Dèl to ir mūsų šalyse pradèjo reikštis neigiamas $\mathrm{CO}_{2}$ poveikis ir deguonies balansui atmosferoje. Pažymètina, kad daugelis mokslininkų šiandieninį $\mathrm{CO}_{2}$ koncentracijos didejjimą atmosferoje ir su tuo susijusius klimato pokyčius sieja ne tik su organinio kuro naudojimu, bet ir su atogrąžu miškų naikinimu. Taigi vandenynai ir miškai yra didžiausias rezervas, galintis sugerti didejjantị $\mathrm{CO}_{2}$ kieki, kad būtų išvengta ryškaus globalinio atšilimo ir jo katastrofiškų padarinių didžiajai daliai (60-70\%) žmonijos (Brown 1982).

$\mathrm{CO}_{2}$ balanso atžvilgiu mūsų miškų vaidmuo krašto ekologinèje sistemoje atlikus skaičiavimus pagal programą ECOSLIT, paaiškejjo, kad 1955 m., iki prasidedant sparčiam krašto industrializavimui, kasmet $i$ atmosferą iš Lietuvos teritorijos buvo išmetama apie $12 \mathrm{mln}$. $\mathrm{CO}_{2}$. Vèliau šis kiekis eksponentiškai augo, kol 1985-1990 m. pasiekè $42 \mathrm{mln}$. tonų. Nuo 1955 m. labai sumažejus pagrindi- 
nių kirtimų apimtims (1961 m. pagrindiniais kirtimais iškirsta tik 0,77 mln. m3) ir labai padidèjus naujų želdinių plotams (1948-1955 m. želdyta net 15,7-19,8 tūkst. ha kasmet), smarkiai didejjo miškų plotai ir fitomasès kaupimasis juose. Teritorijos miškingumas $1958 \mathrm{~m}$. besudaręs 23,9\%, iki $1990 \mathrm{~m}$., skaičiuojant pagal FAO metodika, padidejjo iki 32,3 procento. Per tą pati laikotarpi (19581993) vidutinis fitomasès kiekis 1 ha padidejo apie 40\%, o bendras fitomasès kiekis Lietuvos miškuose padidejo net 65 procentais. Kadangi kiekvienam absoliučiai sausos fitomasès kilogramui susidaryti absorbuojama $1,84 \mathrm{~kg} \mathrm{CO}_{2}$, per minimą laikotarpi visi Lietuvos miškai vidutiniškai absorbuodavo apie $30 \mathrm{mln}$. t $\mathrm{CO}_{2}$ kasmet (16,6 t CO ha $^{-1}$ ) (Partyka 2010, Lietuvos miškų... 2009).

Iš fitomasès kitimo duomenų matyti, kad 1958-1993 m. laikotarpiu miškų fitomasè padidejo apie $103 \mathrm{mln}$. $\mathrm{t}$ ir pasiekè, skaičiuojant vidutiniškai visai teritorijai, $50 \mathrm{t} \mathrm{ha}^{-1}$, o jos prieaugis buvo kone $8 \mathrm{t} \mathrm{ha}^{-1}$. Taigi mišku ekosistemų fitomasejje buvo papildomai absorbuota $190 \mathrm{mln}$. $\mathrm{CO}_{2}$, arba vidutiniškai $54 \mathrm{mln}$. $\mathrm{t}$ per metus. Drauge padidejo sistemos savaiminio apsivalymo pajègumas.

Pridejjus dar iš miškų per visus kirtimus išimtą medienos tūrị (apie $120 \mathrm{mln}$. m3), kuriame buvo absorbuota daugiau kaip $200 \mathrm{mln}$. $\mathrm{CO}_{2}$, matysime, kad Lietuvos teritorinè sistema pagal $\mathrm{CO}_{2}$ balansą artejja prie nulinès ribos. Visoje krašto teritorijoje išskiriamas $\mathrm{CO}_{2}$ kiekis yra asimiliuojamas augančių miškų.

Dabar Lietuvos teritorijoje yra susikaupę apie $300 \mathrm{mln}$. $\mathrm{t}$ fitomasès, kurios daugiausia (apie $250 \mathrm{mln}$. t) miškuose. Žemès ūkio naudmenu plotuose bendras metinis fitomasės prieaugis (apie $30 \mathrm{mln}$. $\mathrm{t}$ absoliučiai sausos medžiagos), neskaitant humuso, beveik nekaupia fitomasès, nes čia jos apyvartos periodas apie $1-1,5$ metu.

Asimiliuodami iš atmosferos $\mathrm{CO}_{2}$ dujas miškai kaupia angli, kurios medienoje yra apie 50\%. Neatsitiktinai Kyoto protokolą, kuri pasiraše ir Lietuva, miškingumo didinimas laikomas kaip kiekvienos šalies indëlis klimato kaitos mažinime. Dèl to Ukraina siekia papildomai iveisti $2,5 \mathrm{mln}$. ha miškų ar net apželdinti apie $10 \mathrm{mln}$. ha nederlingų žemių (dr. V. Pasternak, I. Bukša, Ukrainos miškų ūkio ir miškų melioracijos institutas). Akad. L. Kairiūkštis yra pažymejęs, kad Lietuvoje po II - ojo Pasaulinio karo Lietuvos miškingumas padidejo nuo 19,7\% (1984 m.) iki 32,7\% (2007 m.). Priešingai, nuo $1990 \mathrm{~m} . \mathrm{CO}_{2}$ ištakos (emisijos) sumažèjo 2 kartus. Todèl dabar Lietuvos miškai savo biomasèje „užkonservuoja“" net 55-55\% vietinių $\mathrm{CO}_{2}$ emisijų arba virš 2 - kartų daugiau negu reikalauja Kyoto protokolas (20-22\%) (Lietuvos miškų... 2009).

Miškuose su medžių ir kitos augalijos nuokritomis bei atmirštant šaknims organinè $\mathrm{C}$ kaupiasi dirvožemiuose. Europos mastu taip atmosferos $\mathrm{CO}_{2}$ dujų miško dirvožemiuose sukaupta apie 1,5 karto daugiau negu medžių stiebų masejje. Tyrèjai dr. K Armolaitis, J. Aleinikovienè dr. I. Varnagirytė Kabašinskienè atliko pušynuose tyrimus, kurių metu nustate, kad daugiausia (50-80\%) organinès anglies sukaupta mineralinių horizontų viršutiniame $30 \mathrm{~cm}$ 
storio sluoksnyje, 20-25\% - normalaus ir laikinojo drèkinimo augaviečiu miško paklotèje.

Vienareikšmiškai vertinti miškus sekvestruojant angli negalima. Medžiai ir kita miško augalija, kaip ir kiekvienas gyvas organizmas, „kvejpuoja“. Nemaži kiekiai $\mathrm{CO}_{2}$ i atmosferą tai pat sugrižta, kai mikroorganizmai skaido virtėlius, miško paklotę bei dirvožemio organines medžiagas. Tokių tyrimų trūksta. Prof M. Mareko (Brno Mendelio žemès ūkio universitetas, Čekija) atliko tyrimus pastatydamas miškuose bokštelius, kur skirtingame aukštyje (virš dirvožemio, medžiu arde ir virš medyno) nuolatos fiksuojamos $\mathrm{CO}_{2}$ ir $\mathrm{H}_{2} \mathrm{O}$ ore koncentracijas, meteorologinius rodiklius. Tai leido ivertinti fofosintetiškai aktyvios Saulès spinduliuotès, oro temperatūros, vejjo itaką $\mathrm{CO}_{2}$ akumuliacijai miško ekosistemose. Irodyta, kad miškai $\mathrm{C}$ sukaupia 3-5 kartus daugiau negu grąžina $\mathrm{CO}_{2}$ dujomis atgal į atmosferą (Bukantis 2001, Verma 2005).

Atlikus miškų vaidmens klimato kaitai analizę nustayta, kad Lietuva ne tik savo mažu dydžiu, bet ir absoliučiais skaičiais bei uždaru balansu neprisideda prie šiltnamio efekto.

\subsection{Bedrosios anglies kitimo matematiniai modeliai}

Bendrosios anglies kiekiui modeliuoti globaliu, regioniniu mastu yra naudojami šie modeliai: Biome-BGC, Century, TEM, PnET, LoTEC.

Biome-BGC (BioGeochemical Cycles/Biogeocheminis ciklas) modelis imituoja NPP daugialypes biomases. Kadangi NPP yra apskaičiuotas kaip skirtumas tarp imituoto GPP ir kvejpavimo fotosintezès metu. Nors modelyje buvo pridèta azoto kitimo dinamika, Biome-BGC pasitiki pirmiausiai hidrologiniu ciklu nuo kurio priklauso $\mathrm{C}$ sunaudojimas ir laikymas. $\mathrm{CO}_{2}$ išsiskyrimą apsprendžia NPP, pagal kurị nustatomas išgaravimo, jungto su pažemintu lapo laidumu, o ne grižztamaisiais ryšiais nuo maistingu medžiagu transformacijos ciklo. Biome-BGC turi kasdienini laiko žingsni ir aiškų erdvini mastą (Ruddiman 2003, Batjes 1999).

Century (Šimtmetis) modelis imituoja angli, maistingą medžiaga, ir vandeninę dinamiką skirtingiems ekosistemos tipams. Century apima dirvožemio organinę medžiaga, bei irimo submodeli, vandeninị biudžeto submodeli, du augalo augimo submodelius (pieva ir miškas). Modelis skaičiuoja srautus: anglies, azoto, ir (pasirinktinai), fosforo, ir sieros. Anglies sunaudojimas Century modelyje yra kontroliuotas pirmiausiai azoto sunaudojimu. Pievos/derliaus submodelis ir miško augimo submodelis mano, kad ménesinè maksimali augalo biomases gamyba yra kontroliuota drègmès ir temperatūros, ir kad maksimalios augalo gamybos normos priklauso nuo maistingų medžiagų tinkamumo. Century modelis naudoja mėnesinį laiko žingsnị (Soil Resources of Europe, second edition 2005). 
1.3. lentelè. Modeliavimo programų duomenų įvestis

Table 1.3. Simulation programs data input

\begin{tabular}{|c|c|c|c|c|c|}
\hline Pavyzdinès ịvestys & Century & $\begin{array}{c}\text { Biome-- } \\
\text { BGC }\end{array}$ & TEM & PnET & LoTEC \\
\hline Klimatas & $\begin{array}{c}\text { Kas } \\
\text { mėnesį }\end{array}$ & Kasdien & $\begin{array}{c}\text { Kas } \\
\text { mėnesị }\end{array}$ & $\begin{array}{l}\text { Kas } \\
\text { mėnesį / } \\
\text { kasdien }\end{array}$ & $\begin{array}{l}\text { Kasdien } \\
\text { / kas } \\
\text { valandą }\end{array}$ \\
\hline Vidutinè oro temp. & - & - & $X$ & $\mathrm{X}$ & $\mathrm{X}$ \\
\hline Maksimali oro temp. & $X$ & $\mathrm{X}$ & - & $\mathrm{X}$ & - \\
\hline Minimali oro temp. & $\mathrm{X}$ & $\mathrm{X}$ & - & $\mathrm{X}$ & - \\
\hline Santykinis oro drėgnumas & - & $\mathrm{X}$ & - & - & - \\
\hline Slègis & - & $\mathrm{X}$ & - & - & $\mathrm{X}$ \\
\hline Saulès spinduliuotè & - & Vidurkis & $\mathrm{X}$ & Vidurkis & $\mathrm{X}$ \\
\hline $\begin{array}{l}\text { Fotodirbtinai aktyvi radi- } \\
\text { acija }\end{array}$ & - & $\mathrm{X}$ & - & - & - \\
\hline Dienos ilgumas & - & $\mathrm{X}$ & - & - & - \\
\hline \multicolumn{6}{|c|}{ Dirvožemio ypatybės } \\
\hline Dirvožemio tankis & $\mathrm{X}$ & $\mathrm{X}$ & $\mathrm{X}$ & $\mathrm{X}$ & - \\
\hline Struktūra \% smėlis/molis & $\mathrm{X}$ & - & $\mathrm{X}$ & - & - \\
\hline Gylis & $\mathrm{X}$ & $\mathrm{X}$ & - & - & - \\
\hline Vandens sulaikymo geba & - & $\mathrm{X}$ & - & $\mathrm{X}$ & - \\
\hline Azoto kiekis dirvožemyje & $\mathrm{X}$ & Gautas & - & - & - \\
\hline $\begin{array}{l}\text { Anglies kiekis dirvože- } \\
\text { myje }\end{array}$ & $\mathrm{X}$ & Gautas & - & - & - \\
\hline \multicolumn{6}{|c|}{ Augmenijos ypatybès } \\
\hline Biomo tipas & - & $\mathrm{X}$ & - & - & $\mathrm{X}$ \\
\hline Augmenijos tankis & $\mathrm{X}$ & $\mathrm{X}$ & $\mathrm{X}$ & $\mathrm{X}$ & - \\
\hline $\begin{array}{l}\text { Kitos maistingos medžia- } \\
\text { gos (pavyzdžiui, P, S, } \\
\text { Lignin) }\end{array}$ & $\begin{array}{l}\text { Laisvai } \\
\text { pasi- } \\
\text { renkamas }\end{array}$ & - & - & - & - \\
\hline Gylio isišaknijimas & $\mathrm{X}$ & $\mathrm{X}$ & - & - & - \\
\hline Fotosintezė & - & - & - & $\mathrm{X}$ & - \\
\hline \multicolumn{6}{|c|}{ Erdvinès ypatybès } \\
\hline Platuma & $\mathrm{X}$ & $\mathrm{X}$ & $\mathrm{X}$ & $\mathrm{X}$ & - \\
\hline Ilguma & $\mathrm{X}$ & - & $\mathrm{X}$ & $\mathrm{X}$ & - \\
\hline Albedas & - & $\mathrm{X}$ & - & - & - \\
\hline
\end{tabular}


TEM The Terrestrial Ecosystem Model. Žemès Ekosistemos Modelis yra pagrịstas ekosistemos modelis, kuris apibūdina anglies ir azoto dinamiką Žemès ekosistemos augaluose ir dirvožemiuose. Šis modelis imituoja GPP apribojima, esant daugialypiams faktoriams. Kadangi augalo kvèpavimas yra aiškiai modeliuotas, NPP yra imituotas kaip skirtumas tarp GPP ir anglies sunaudojimo kvépavimo procese. TEM aiškiai imituoja azoto mineralizaciją ir imobilizacijos dinamiką. Tačiau, TEM nesvarsto fotosintezès ir slègio sąryšio. TEM panaudoja erdviškai nurodytą informaciją apie klimatą, dirvožemius, augmeniją ir vandenini sunaudojimą. Taip pat analizuoja dirvožemi - ir specifinius augmenijos parametrus, kad padarytų ménesinius anglies ir azoto srautų ir baseino dydžių apytikrius apskaičiavimus. TEM veikia menesiniu laiko žingsniu. TEM modelis yra globalinis modelis su erdviniu 0,5 laipsnių platumos ir ilgumos sprendimu (McGuire 2004).

I PnET modelių komplektą ieina anglies kitimo imitavimas, vandens ir miško ekosistemu azoto dinamika. Algoritmai tokie kaip fotosinteze yra identiški tarp pavyzdinių versijų. PnET - diena naudoja specifini lapo svorį, N koncentracija, temperatūrą ir radiaciną srautą, kad numatytų kasdieninę grynają visų miško uždangu fotosintezę. PNET analizuojamas anglies ir kvėpavimo ciklus, taip pat vandenini balansa, kad numatytų NPP. Empiriniai dirvožemžio kvėpavimo ciklai leidžia prognozuoti visos anglies ekosistemos balansą su supančiomis sąlygomis. Ši versija yra naudojama, kad numatytu jungtinius klimato pasikeitimo padarinius ir padidejjusi atmosferini $\mathrm{CO}_{2}$ kieki. PnET-CN skiriama sumedejjusiai biomasei ir dirvožemžio organinei medžiagos algoritmams ir dirvožemio irimui, kad parodytų anglies ir azoto ciklų skaičiavimą. Originalus PnET naudoja ménesinį laiko žingsni. PnET modeliai neturi aiškaus erdvinio masto, bet jie taikomi kaip regioniniai (Ollinger 2002, 1996, Postek 1995).

LoTEC yra mechaninis $\mathrm{CO}_{2}$ bei $\mathrm{H}_{2} \mathrm{O}$ srauto tarp dirvožemio - augalo ir atmosferos modelis. Fotosintezè yra apibūdinta "Bigleaf" ar C3 ar C4 biocheminiu modeliu pagrindu. Anglinè dirvožemžio dinamika yra imituota mėnesiniu laiko žingsniu. Šis modelis naudoja empirini Majamio modelį, apimdamas faktorių, kuris analizuoja $\mathrm{CO}_{2}$ kitima. LoTEC naudojimas yra geriausiai pateisintas, kai šviesa yra apribojimo faktorius (Garten 1999, 2000, Hanson 2000).

Apžvelgus programas matyti, kad dauguma programų pagrindiniai įvesties parametrai s sutampa. Duomenis, kurių reikia atlikti modeliavimui galima suskirstyti grupemis. Klimatinių rodikliai îvedami arba valandiniai arba mėnesio vidutiniai. Sekantys duomenys i̇vedami apie dirvožemi, bei augalijos ypatybes. Ivedamų duomenų tipai ir kiekis vèlgi yra labai skirtingi. Tačiau tokiems modeliams kaip LoTEC ivesties duomenų kiekis yra ganètinai mažas. Dirbti tokiomis programomis yra paprasčiau, nors gauti rezultatai ne visuomet yra tikslesni. 


\subsection{Pirmojo skyriaus išvados ir disertacijos uždavinių formulavimas}

1. Literatūros analizè atskleidè, kad anglies kiekis dirvožemiuose nuolatos mažeja. Labiausiai pažeidžiami yra lengvos granuliometrinès sudèties dirvožemiai. Pagrindinès problemos, sąlygojančios anglies kiekių mažejimą dirvožemiuose, yra dirvožemio erozija, neracionalus ūkininkavimas, miškų kirtimas. Taip pat atskleista, kad nèra pakankamai vykdomų anglies dioksido emisijų tyrimų arba jie atliekami pasenusiais metodais.

2. Vienareikšmiškai vertinti miškus sekvestruojant anglị negalima. Medžiai ir kita miško augalija, kaip ir kiekvienas gyvas organizmas, „kvejpuoja“. Nemaži kiekiai $\mathrm{CO}_{2}$ i atmosferą tai pat sugrižta, kai mikroorganizmai skaido virtèlius, miško paklotę bei dirvožemio organines medžiagas. Tokių tyrimų trūksta.

3. Dirvožemyje organinių medžiagu apykaitai itakos turi klimato veiksniai, bakterijos, kurios skaidydamos daugybę tonų i̇vairiausių nuokritų, organizmų lavonų, ivvairių organinių atliekų, dirvožemyje pagausina puvenų (humuso).

4. Atsižvelgiant i faktorius įtakojančius organinès anglies skaidymąsį ir oksdidaciją iki anglies dioksido, išskiriami pagrindiniai veiksniai: drègmè, temperatūra, mikroorganizmų aktyvumas. Anglies dioksido išsiskyrimą tai pat itakoja augalų vegetacinis laikas bei paros laikas.

5. Apžvelgus modeliavimo programas nustatyta, kad i skaičiavimo algoritmus pagrindiniai įvesties duomenys sudaro atmosferinès sąlygos bei dirvožemio struktūriniai parametrai. Papildomai ịvedami biomasès dinamikos duomenys, fotozintesès aktyvumas, geografinè padètis.

6. Pagrindinès problemos sąlygojančios anglies kiekių mažėjimą dirvožemiuose yra dirvožemio erozija, neracionalus ūkininkavimas, miškų kirtimas. Racionalus dirbamų laukų ir miško išteklių naudojimas sumažintų anglies kiekių praradimus dirvožemyje, tačiau problemos slypi giliau ir yra veikiamos ne tik žmogaus, bet ir klimato veiksnių.

Atsižvelgiant i literatūros analizę formuluojami igyvendinti šie uždaviniai:

1. Atlikti bendrosios anglies kiekio ir anglies dioksido emisijos skirtingos žemènaudos dirvožemiuose tyrimus.

2. Ivertinti anglies dioksido emisijos iš dirvožemio dèsningumus ir sąsają su bendrosios anglies kiekiu.

3. Modeliuojant ivvertinti bendrosios anglies kiekio pokyčius ir anglies dioksido emisijos prognozes, taip pat priklausomybę nuo klimato rodiklių. 



\section{2}

\section{Skirtingos panaudos dirvožemių bendrosios anglies kiekio natūriniai tyrimai ir vertinimas}

Anglies kiekis dirvožemyje yra vienas pagrindinių veiksnių, pagal kuriuos nustatoma dirvožemio būklè. Dirvožemio degradacija yra rimta problema ir jos pasekmès neigiamai veikia dirvožemi, neleidžia jam atlikti daugybès funkcijų, reikalingų žmonèms ir ekosistemoms.

Bendrosios anglies tyrimais dirvožemyje siekiama spręsti organinès medžiagos praradimo iš dirvožemio problemą. Tinkamiausias būdas parenkamas atsižvelgiant $\mathfrak{i}$ vietovès charakteristika, medžiagų koncentracija, teršalų kieki ir pan. Bendrosios anglies kiekio skirtingos panaudos dirvožemiuose tyrimai atlikti Neries regioniniame parke bei Paluknio Užpalių ir Pailiepio vietovèse (Baltrènas, Pranskevičius, Lietuvninkas 2008, 2010). 


\subsection{Dirvožemio bendrosios anglies kiekio tyrimų skirtingos panaudos dirvožemiuose metodika}

Metodikos tikslai:

1. nustatyti dirvožemio paèmimo vietas;

2. nustatyti èminių paèmimo kieki;

3. nustatyti dirvožemio mèginio paėmimo gylį, atsižvelgiant i dirvožemio panaudos sriti (miškas, pieva, dirbama žemè).

Dirvožemio éminiu paèmimas Neries regioniniame parke.

Neries regioninio parko vietove pasirinkta siekiant išvengti antropogeninių faktorių itakos (2.1 pav.). Dirvožemio pavyzdžiai buvo imami kovo, rugpjūčio ir rugsèjo mènesi.

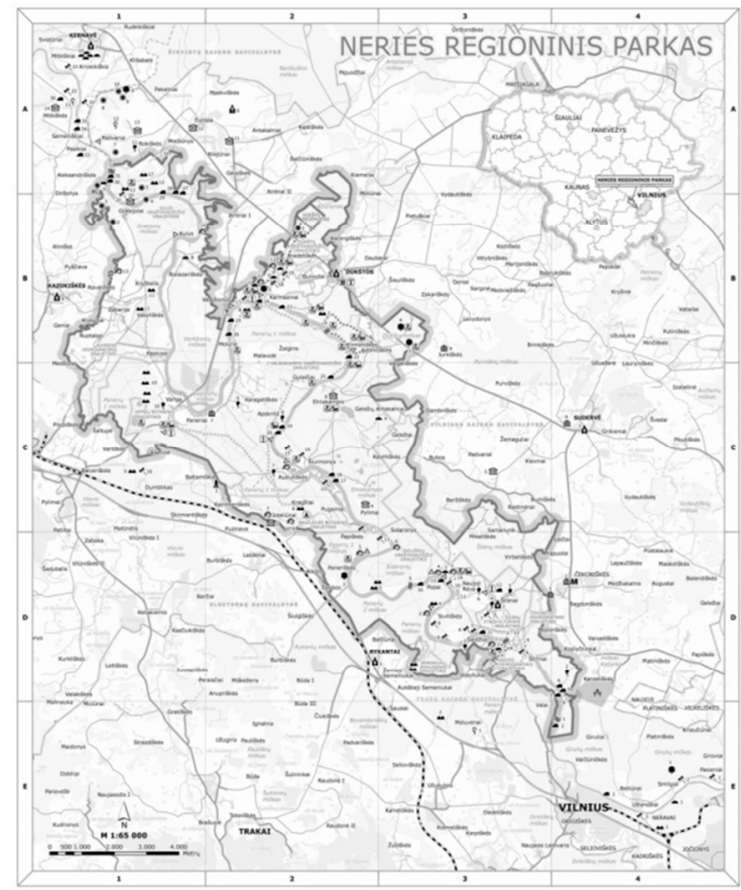

2.1 pav. Neries regioninio parko žemèlapis (Neries 2010)

Fig. 2.1 Neris Regional Park Map (Neries 2010)

Tyrimai atliekami siekiant sudaryti duomenų bazę, kuria vèliau būtų galima naudoti modeliavimui, o tai pat išanalizuoti skirtingos panaudos dirvožemių bendrosios anglies kitimą. Dirvožemio èminiai buvo imti: pievoje, ariamame ir miško dirvožemyje. Tyrimo vietos parinktos taip, kad joms neturètų itakos ant- 
ropogeniniai veiksniai, o taip pat atsižvelgiant $\mathfrak{i}$ vietovès padètị reljefe (elementariuose geocheminiuose landšaftuose).

Miško dirvožemio èminiai paimti iš Panerių miško, pievos - netoli Čekonès upelio (dešinysis Neries krantas) ir pievoje Malavonès vietovejje (kairysis Neries krantas).

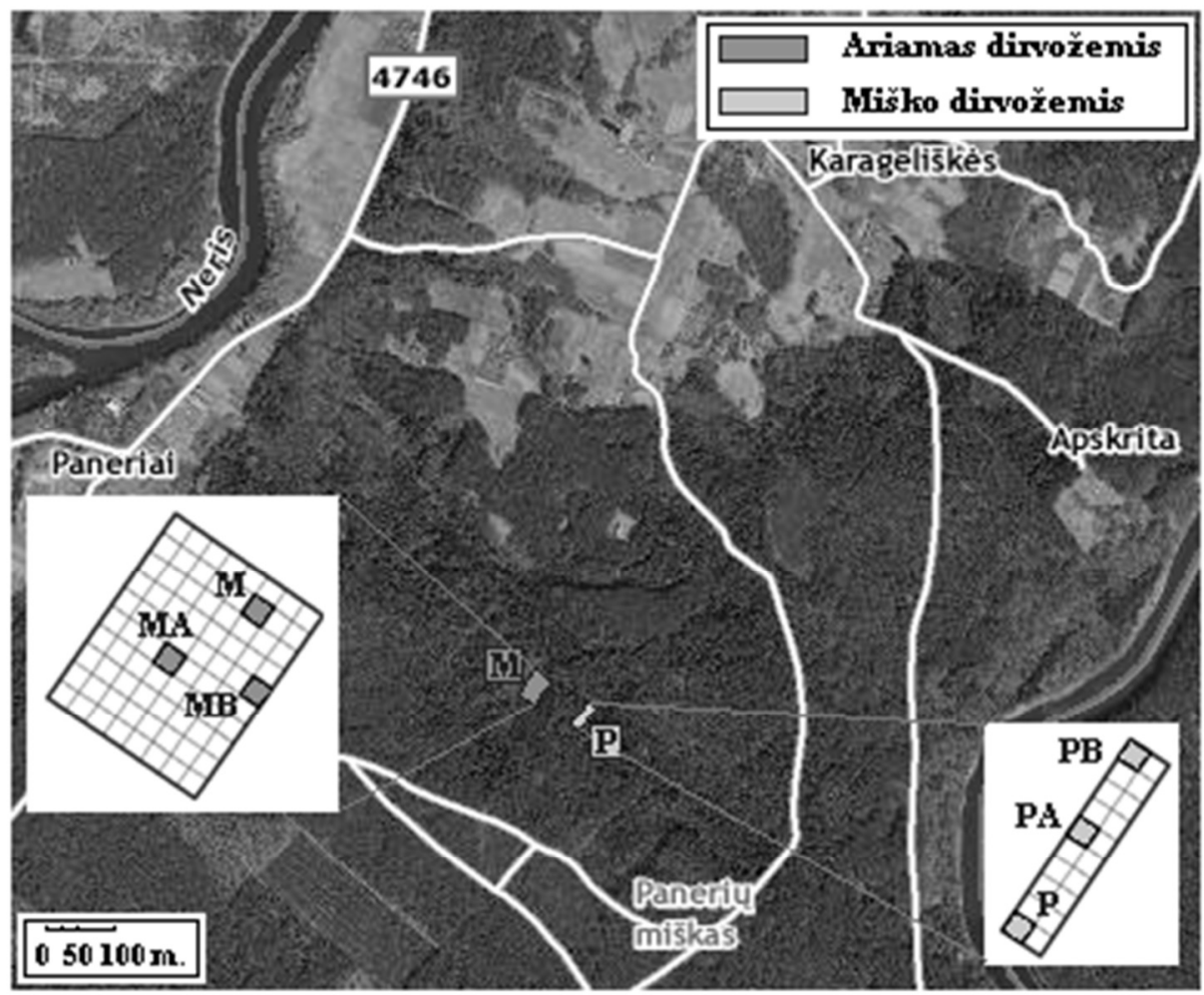

2.2 pav. Miško (P, PA, $\mathrm{PB})$ ir ariamo (M, MA, MB) dirvožemio tyrimo vietų parinkimas (LKS koordinatės M (559418; 6071913); MA (559418; 6071924); MB (559431; 6071924); P (559519; 6071901); PA (55949; 6071889) PB (559500; 6071913)

Fig. 2.2. Forest (M, PA, PB) and arable (M, MA, MB) soil survey site selection (LKS coordinates M (559418; 6071913); MA (559418; 6071924); MB (559431; 6071924); P (559519; 6071901); PA (55949; 6071889) PB (559500; 6071913)

Éminių vietose GPS prietaisu nustatytos koordinatès, vèliau konvertuotos i LKS koordinačių sistemą. Aprašyta teritorija, ją supantys augalai ir reljefo ypatumai. 
Miško dirvožemio ėminiams parinktas Panerių miškas. Ėminių vietoje vyravo eglynai ir nedidelis kiekis lapuočių medžių. Atsižvelgiant i landšaftą, buvo pasirinktos 3 (P, PA, PB ) tyrimo vietos (2.2 ir 2.3 pav.). Gretimais paimti ariamo dirvožemio éminiai tyrimo vietose $\mathrm{M}, \mathrm{MA}, \mathrm{MB}$. Atstumas nuo ariamo dirvožemio - 71 metras (2.2 pav). Dirvožemio paimta reljefo nuolydžio kryptimi. Pirmoji, P èminių tyrimo vieta, parinkta autonominiame landšafte. Antroji, PA èminių tyrimo vieta, parinkta 20 metrų atstumu nuo P ploto, nuolydžio centre. Sekanti tyrimo vieta PB pasirinkta netoli upelio vagos superakvaliniame elementariajame landšafte 17 metrų atstumu nuo PA ploto. Reljefo nuolydžio kampas sudare $18^{\circ}$.

Ariamo dirvožemio èminiai paimti iš 3 tyrimo vietų (M, MA, MB) suartame lauke (2.2 pav.). Dirvožemyje tyrimo metu augo ankštiniai ir grūdiniai augalai. Dirvožemis tręštas organinès kilmès medžiagomis.

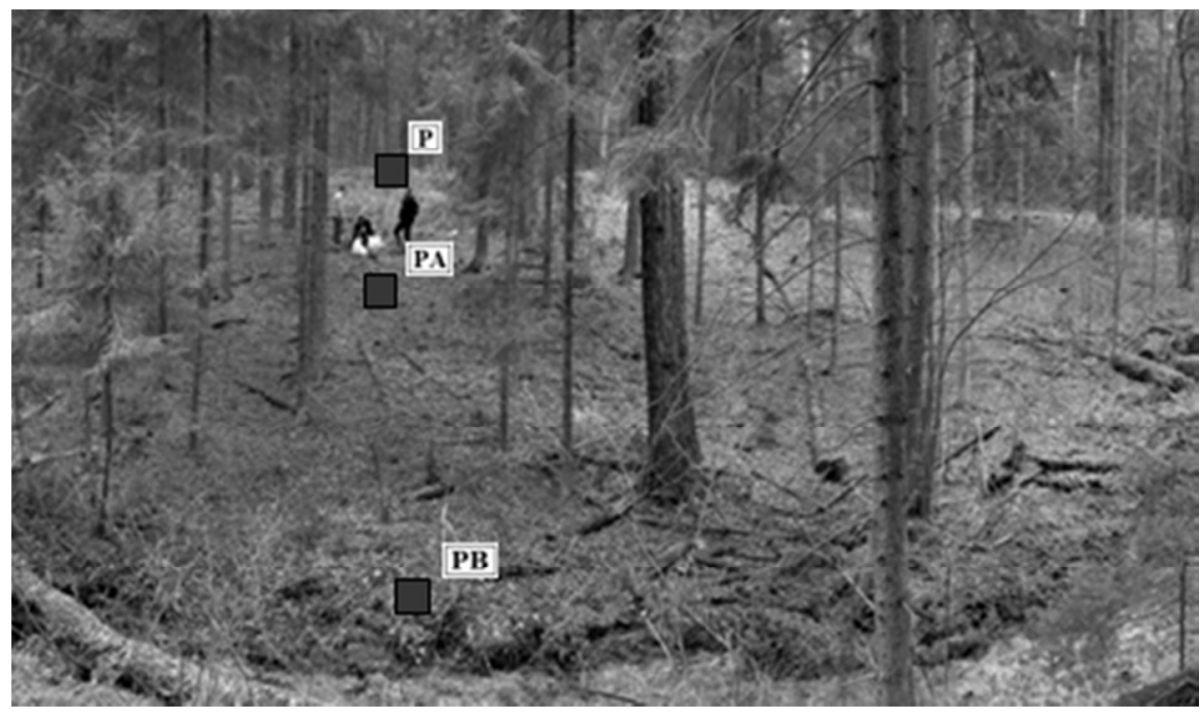

2.3 pav. Miško dirvožemio ėminių paèmimas $\mathrm{P}, \mathrm{PA}, \mathrm{PB}$ tyrimo plotuose Panerių miške

Fig. 2.3. Forest soil sampling P PA PB Paneriai forest investigation sites

Pievos dirvožemio ėminiai tyrimo vietose $\mathrm{K}$ ir KA paimti kaip parodyta 2.4 pav., Siviliškès vietovejje 100 x 40 metrų plote. Dirvožemio èminiai paimti iš esančios užliejamos pievos, kurioje nešienaujama. Pagrindinę augaliją sudarè nekultūrinai, smilginiai augalai. Kai kuriose pievos vietose auga pušu jaunuolynas, bei pavieniai krūmynai.

KA dirvožemio tyrimo vieta yra 24 metrų atstumu nuo Neries kranto, $\mathrm{K}$ tyrimo vieta nuo KA nutolusi $50 \mathrm{~m}$ atstumu. 


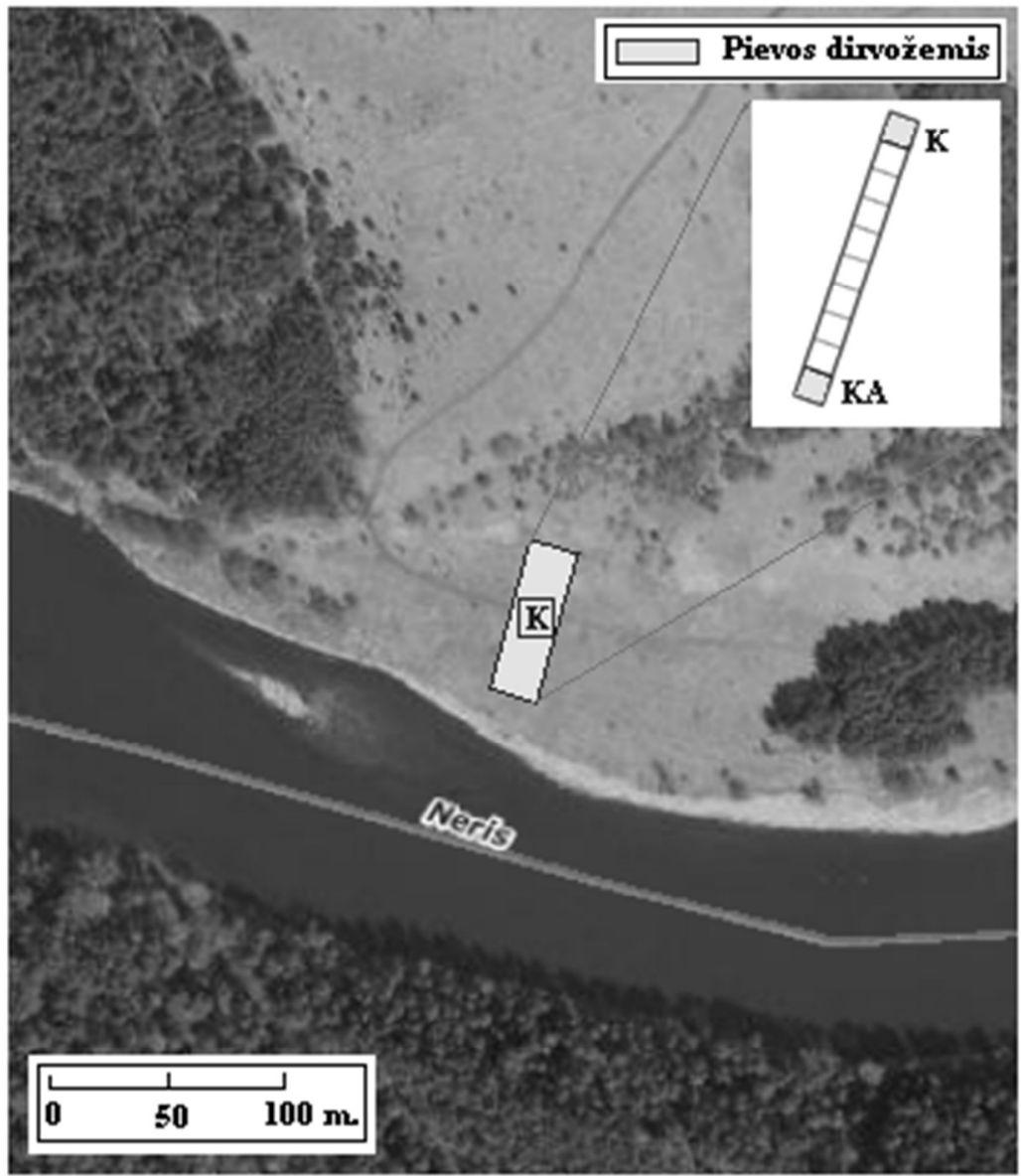

2.4 pav. Pievos dirvožemio ėminių paėmimo vieta (LKS koordinatès K tyrimo vieta $(565949 ; 606554)$; KA tyrimo vieta $(565933 ; 6065494)$ ) Fig. 2.4 Grassland soil sampling location (LKS coordinates of the K investigation sites (565949; 606554); KA investigation sites (565933; 6065494))

Pievos ėminiai tyrimo vietose E, EA ir EB paimti dešiniajame Čekonės upelio krante 100 × 50 metrų plote. Vietoveje silpnai kalvota. Nuolydžiai Čekonès upelio link sudare 40 metrų, vietomis iki 60 metrų su $32-47^{\circ}$ nuolydžiu (2.5 pav.). Pievos èminiai, paimti tyrimo vietose E ir EA, priklauso autonominiam landšaftui, tyrimo vieta $\mathrm{EB}$ - superakvaliniam elementariajam geocheminiam landšaftui. Tyrimo vieta EB nutolusi 60 metrų atstumu nuo EA tyrimo vietos. Tyrimo vietos EA èminiai paimti gruntinio vandens lygyje. Pažymètina, kad humusingas dirvožemio sluoksnis čia sudarè iki $40 \mathrm{~cm}$. 


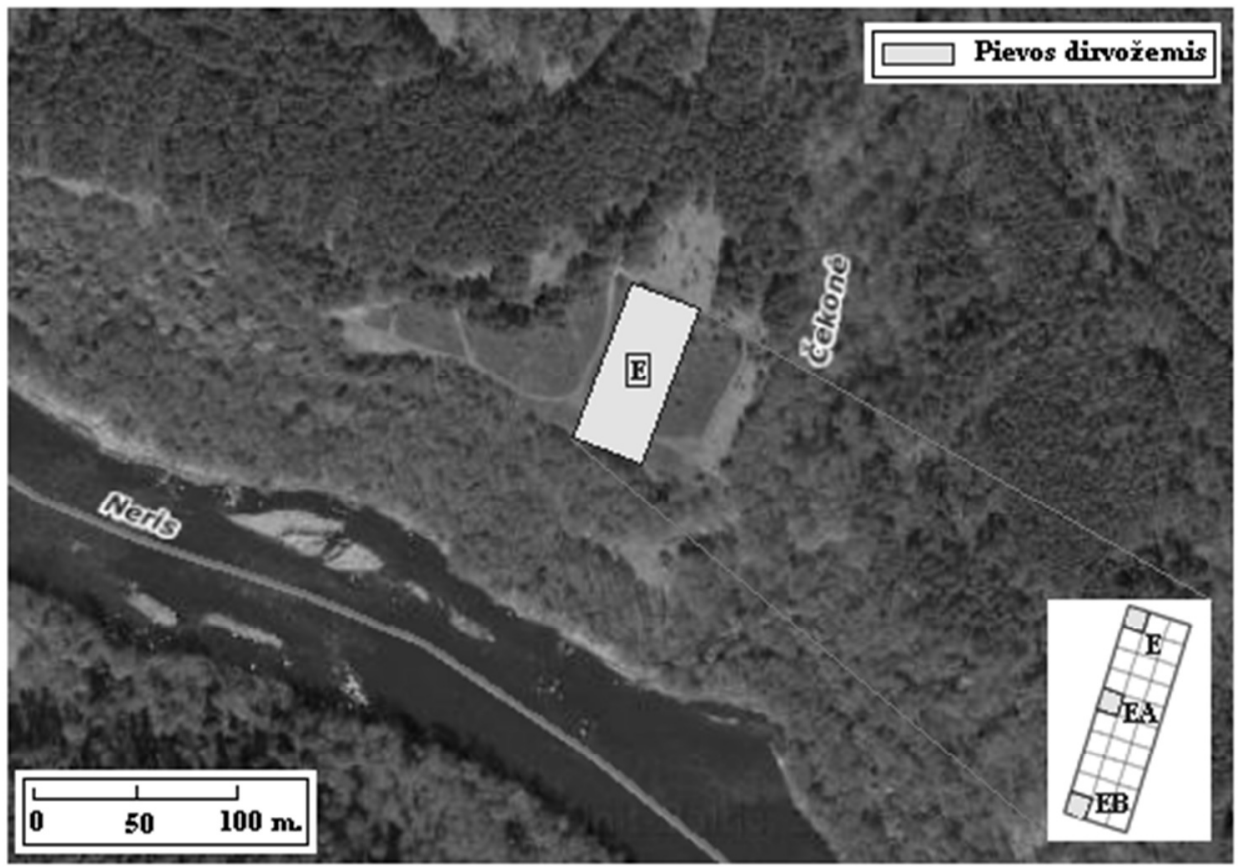

2.5 pav. Pievos dirvožemio ėminių paėmimo vietos ties Čekonės upeliu (LKS tyrimo vietų koordinatès E (568088; 6065541); EA (568072; 6065514); EB (568066; 6065495)

Fig. 2.5. Grassland soil sampling at the local river Čekonè (LKS coordinates of the investigation sites s E (568088; 6065541); EA (568072; 6065514); EB $(568066 ; 6065495)$

Dirvožemio ėminiai bendrosios anglies kiekio nustatymui paimti Paluknyje, Užpaliuose ir Lazdijų rajono savivaldybès Pailiepio miške. Dirvožemio ėminiai imti birželio ménesí. Šiose vietovèse atlikti sudettinių ir nesuardytos struktūros èminių bendrosios anglies tyrimai. Sudetiniai èminiai paimami iš visų tiriamų èminių paėmimo vietų, esant vienodam gyliui, $1 \mathrm{~kg}$ dirvožemio ėminys. Nesuardytos struktūros èminiai imti naudojantis specialiu grąžtu arba naudojant metalinị žieda. Tokiu būdu buvo papildomai tiriama, kaip galima optimizuoti didelio kiekio dirvožemio ėminių paèmimą.

Raseinių rajono savivaldybès Paluknio vietovejje paimti ariamos žemès dirvožemio ėminiai, o Utenos rajono savivaldybès Užpalių vietovejje paimti pievos èminiai (2.6 pav.).

Užpalių vietoveje tyrimo vietose G, GA ir GB paimti pievos dirvožemio èminiai 50 × 50 metrų kvadrato plote. Pagrindinè augalija pievoje dobilai ir 
smilginiai augalai. Pieva buvo šienaujama. Atstumas iki kelio nuo analizuojamo ploto sudare $8 \mathrm{~m}$.

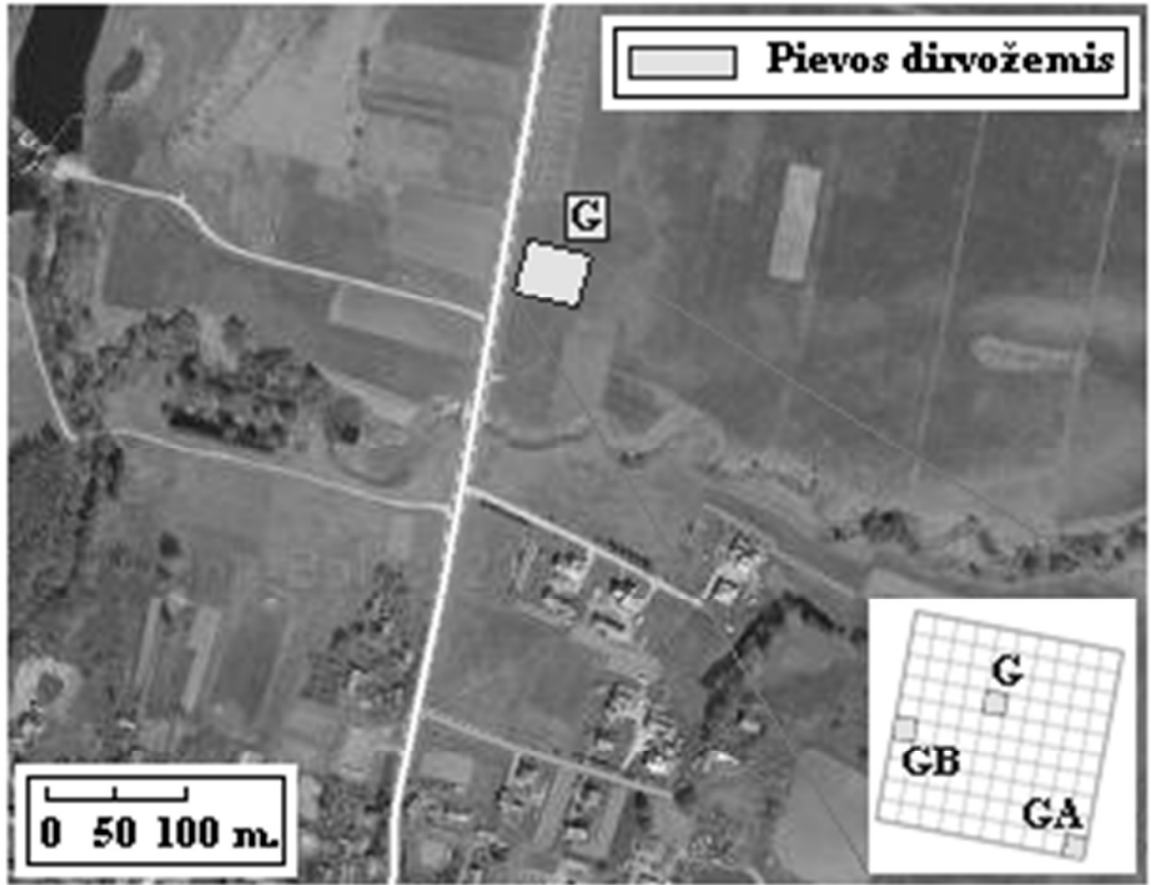

2.6 pav. Užpalių pievos dirvožemio ėminių paėmimo vieta (tyrimo vietų LKS koordinates G (599903; 6168951); GA (599876; 6168935); GB (599912; 6168924))

Fig. 2.6. Grassland soil of Užpaliai sampling site (investigation sites LKS coordinates G (599903; 6168951); GA (599876; 6168935); GB (599912; 6168924))

Paliepio miško dirvožemio ėminiai tyrimo vietose paimti pušyne, kuriame auga pavieniai lapuočiai ir krūmynai (2.7 pav.). Ėminiai paimti 50 x 50 metrų plote trijuose tyrimo vietose R, RA ir RB. Analizuojama vietovè buvo nutolusi nuo kelio 40 metrų atstumu. Vietové lygi, reljefo įtakos tyrimo èminiams nebuvo.

Ariamo dirvožemio ėminiai tyrimo vietose $\mathrm{B}, \mathrm{BA}$ ir BB imti Paluknio vietovèje (2.8 pav.). Dirvožemis, iš kurio imti èminiai, buvo suartas ir išakètas, prieš tai jame auginti pašariniai miežiai. Ėminiai paimti 50 x 50 metrų kvadrato plote. Šis analizès plotas nuo pagrindinio kelio buvo nutolęs 10 metrų, o nuo šalutinio nuo 20 iki 7 metrų atstumu. 


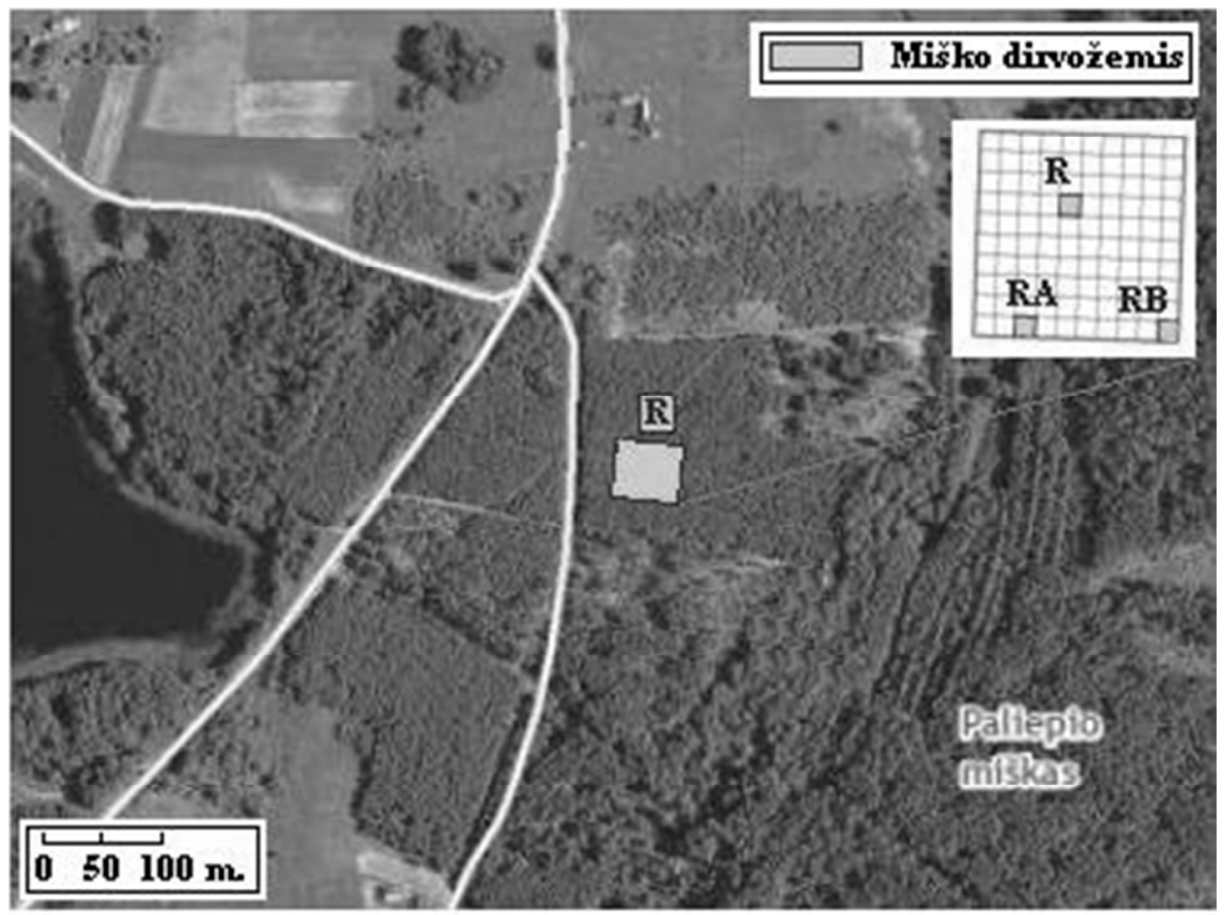

2.7 pav. Pailiepio miško dirvožemio ėminių paėmimo vieta (tyrimo vietų LKS koordinates R (485862; 5984588); RA (485833; 5984553); RB (485883; 5984548))

Fig. 2.7. Pailiepio forest soil sampling site (LKS coordinates of the R investigation sites (485862; 5984588); RA (485833; 5984553); RB $(485883 ; 5984548))$

Užpalių Paluknio ir Pailiepio vietovèse dirvožemio sudètiniai ėminiai imti kas 10 centimetrų trijuose gyliuose, o nesuardytos struktūros èminiai imti iki 25 $\mathrm{cm}$ gylio kas 5 centimetrus. Viso paimta ir išanalizuota 72 dirvožemio ėminiai.

Neries regioniniame parke dirvožemio èminiai imti naudojantis specialiu gražtu iki 30 centimetrų gylio kas 10 centimetrų. Viso paimta ir ištirta dirvožemio èminių -297.

Imant dirvožemio èminius naudojamasi tinkleliu. Tinklelis sudarytas iš 100 narvelių kurių indentifikavimo numeris yra išdèstytas atsitiktine tvarka (2.9 pav.). Analizuojamas dirvožemio plotas, pažymètas raudona linija, turi tilpti i tinkleli. Pasirinktas dirvožemio plotas gali būti stačiakampis arba bet kokios kitos formos. Jei analizuojamas plotas netaisyklingos formos, tuomet nustatomos ir tinklelio kampų koordinatès. Tai atliekama palengvinti narvelio matmenų nustatymą. 


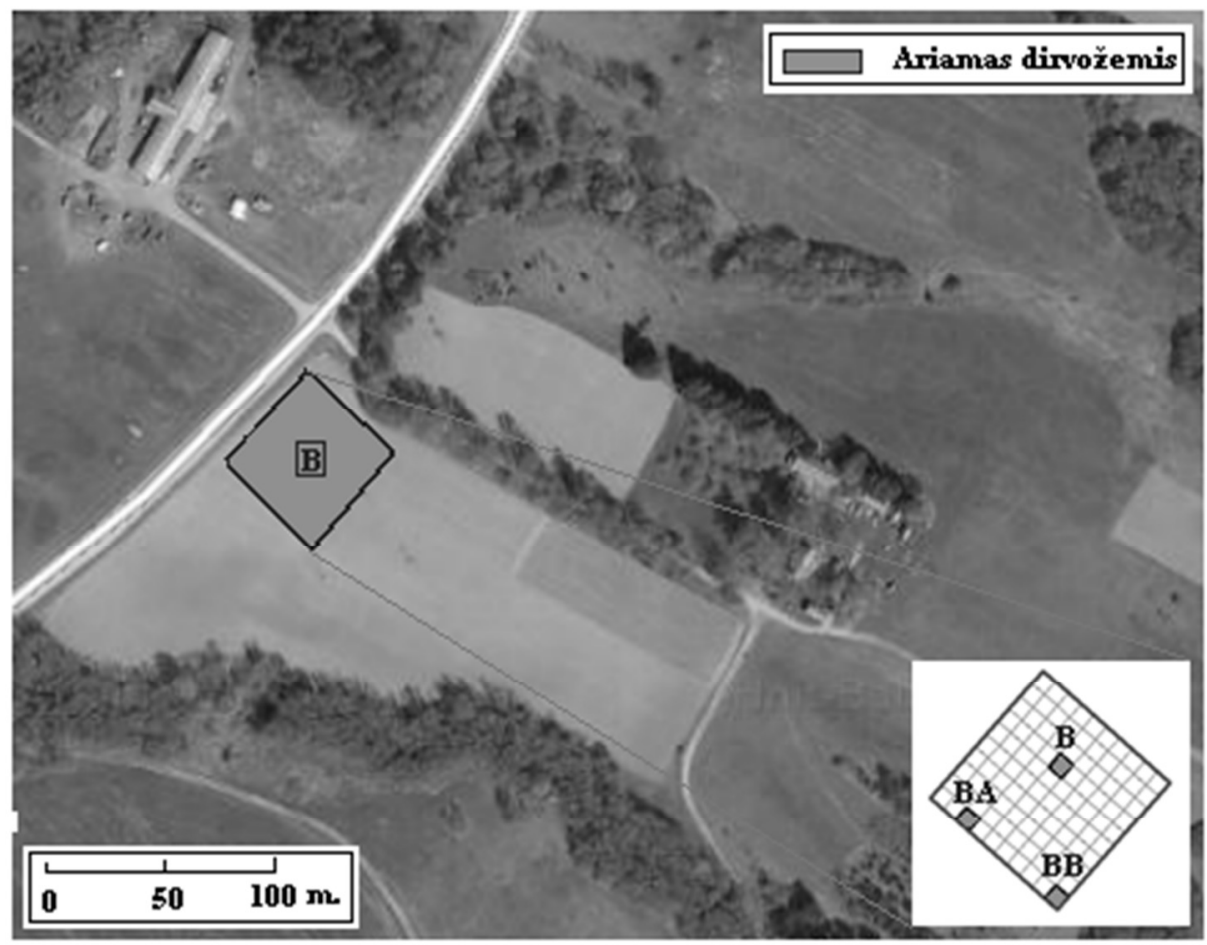

2.8 pav. Paluknio ariamo dirvožemio ėminių paèmimo vieta (tyrimo vietų LKS koordinates R (587487; 6145119); RA (587463; 6145108); RB $(587508 ; 6145102))$

Fig. 2.8. Užpaliai arable soil sampling site (LKS coordinates of the R investigation sites (587487; 6145119); RA (587463; 6145108); RB $(587508 ; 6145102))$

Narvelio matmenys nustatomi tinklelio $\mathrm{X}$ ir $\mathrm{Y}$ ašių kraštines padalijus iš 10 . Mèginiai imami sistemingai, atsižvelgiant $\mathfrak{i}$ analizuojamo ploto dydį. 2.7 paveiksle vaizduojami parinkti 1 ir 8 narveliai. Narvelio parinkimas priklauso nuo eilès numerio: imami mažiausią numerị turintys narveliai, patenkantys i analizuojamo dirvožemio plotą. Tie, kurie i analizuojamą plotą patenka iš dalies arba kurių mèginių paimti neimanoma, neitraukiami. Tokiu atveju parenkamas kitas, didesnio iš eilès numerio, narvelis. Dirvožemio èminių paèmimo metu iš analizuojamo ploto imami trys narveliai.

Bendrosios anglies kiekis nustatomas prietaisu SSM-5000A. (2.10 pav.) Prietaiso veikimas pagrịstas sauso mėginio deginimu aukštoje temperatūroje, infraraudonujuc spindulių kamera matuojant išsiskyrusị anglies dioksido kiekị. 
Šiame prietaise anglies oksidacijos reakcijos naudingumo koeficientas kinta priklausomai nuo méginio tipo.

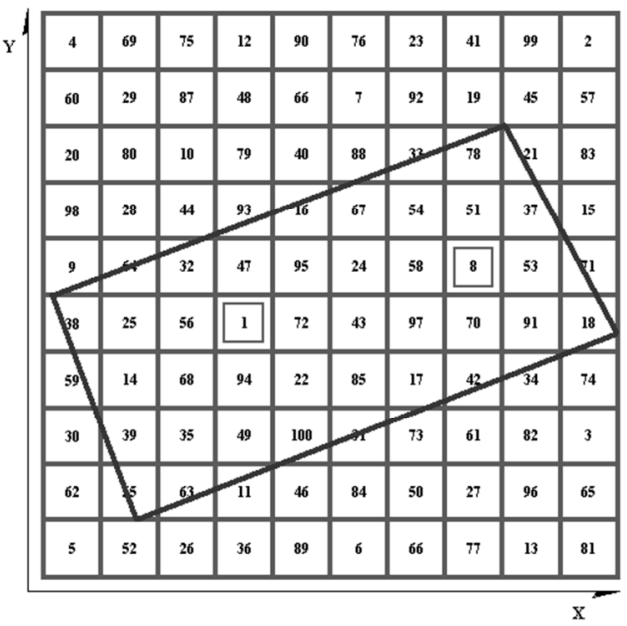

2.9 pav. Dirvožemio ėminių paėmimo pavyzdinis tinklelis. Linija žymi analizuojamo dirvožemio ribas. 1 ir 8 numerio narveliai skirti dirvožemio mèginių paèmimui.

Fig. 2.9. The soil sampling grid model. Line indicates the limits of the analyzed soil. 1 and 8 , the number of cages for the soil samples

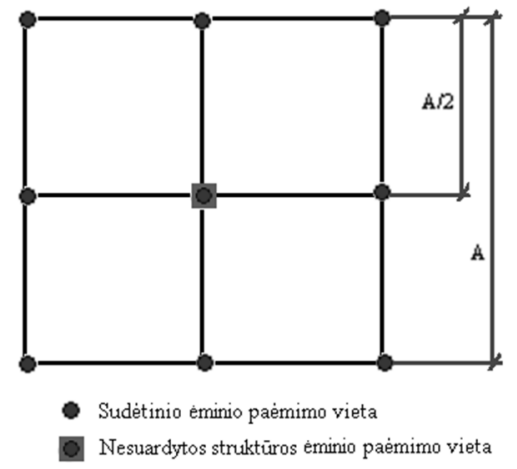

2.10 pav. Dirvožemio mėginių paèmimo vietos: taškai - sudètinio ėminio paėmimo vieta, kvadratas - nesuardytos struktūros èminio paėmimo vieta Fig. 2.10. Soil sampling locations: dots - the complex sampling location, the square - intact structure of the sample collection location 
Taip pat duomenų patikimumas priklauso nuo dalelès dydžio, mėginio sausumo, svorio, nešamujų dujų srovès greičio, mėginio indo (uždengtas ar ne), priedų, kalibravimo standartų tipų. Prieš mėginio analizę nustatomi optimalūs rodikliai. Bendrosios anglies kiekiui nustatyti naudojant kietujų mėginių tyrimo sistema, nešiklio dujos turi tekèti per $200 \mathrm{~mm}$ ir $0,1 \mathrm{~mm}$ NDIR (nedispersines infraraudonąsias) kameras. SSM-5000A nešamujų dujų srovè turi tekèti per 1,0 $\mathrm{mm}$ kamera, kaip valomosios dujos. Matavimo metu bendrosios anglies kiekis negali viršyti $30 \mathrm{mg} / \mathrm{l}$, todèl naudojamas skirtingas mèginio kiekis. Jeigu mėginyje yra per didelis anglies kiekis, naudojamas tyrimui medžiagos kiekis sumažinamas, bet jis negali būti mažesnis kaip $100 \mathrm{mg}$ sausojo svorio. Bendrosios anglies kiekio nustatymo krosnyje darbinè temperatūra yra $900{ }^{\circ} \mathrm{C}$. Tyrimo metu mėginio analizè pradedama tik prietaisui išsivalius nuo atmosferinio anglies dioksido.

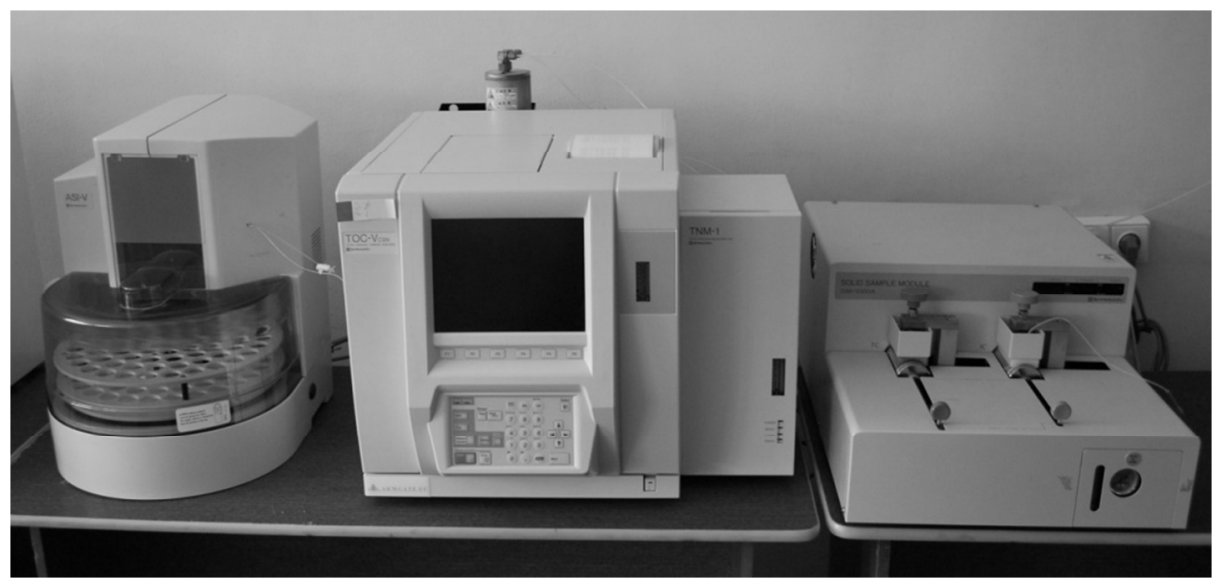

2.11 pav. Shimadzu SSM-5000A bendrosios anglies nustatymo prietaisas

Fig. 2.11. Shimadzu SSM-5000 total carbon measure device

Mèginių ruošimas analizei:

1. Iš mèginio pašalinamos tyrimui nereikalingos medžiagos (pvz. akmenys, stambios šaknys).

2. Dirvožemio ėminiai pieš analizę homogenizuojami. Smulkintuvu ar grūstuvu vèliau èminys kruopščiai susmulkinamas.

3. Susmulkintas èminys persijojamas per reikiamo $1 \mathrm{~mm}$ tankumo sietą.

4. Neišsijotos dalelès susmulkinamos iš naujo.

5. Pakartojamas 3 ir 4 žingsnis, kad gauti galutinį mègini, kuris persijojamas per 200 akučių sietą. 
Prietaiso gamintojas kiekvienam mėginiui rekomenduoja naudoti naują indą. Tačiau jeigu tirtas méginys neužteršè, nepakeitè ar nesugadino indo, ji galima vèl naudoti. Panaudoti indai prieš pakartotinį naudojimą turi būti išplaunami ir iškaitinami, kad pasišalintu prikibę anglies elementai.

\subsection{Dirvožemio bendrosios anglies kiekio natūrinių sezoninių tyrimų Neries regioniniame parke 2009- $2010 \mathrm{~m}$. duomenys ir analizè}

Bendrosios anglies kiekio tyrimai atlikti trijuose skirtingos panaudos dirvožemiuose: miško, pievos ir ariamame dirvožemyje. Tyrimų metu surinkti duomenys apdoroti pagal statistines programas ir nustatytos tyrimo metu gautos paklaidos. Tyrimai buvo atliekami 2009-2010 metais. Matavimai atlikti kovo, birželio, rugpjūčio mènesiais. Dirvožemio pavyzdžiu èmimo metu taip pat buvo nustatytos meteorologinès salygos. Tyrimo metu kovo menesi aplinkos oro temperatūra buvo $14{ }^{\circ} \mathrm{C}$; birželio mènesi $-21{ }^{\circ} \mathrm{C}$; rugpjūčio mènesį- $18{ }^{\circ} \mathrm{C}$.

Miško dirvožemis. Bendrosios anglies kiekio miško dirvožemyje tyrimai atlikti Tyrimo vietose P, PA, PB. (2.2 pav.) Tyrimo vietos parinktos taip, kad kartu būtų nustatyta reljefo itaka bendrosios anglies kiekiui. P tyrimo vieta parinkta autonominiame landšafte, PA tyrimo vieta - transeliuviname elementariajame (šlaito) landšafte PB.

Tyrimo vietoje $\mathrm{P}$ nustatytas bendrosios anglies kiekis kovo mènesi $0-10 \mathrm{~cm}$ gylyje buvo $1,26 \%$. (2.11 pav.) Gilesniuose sluoksniuose jis kito nuo 0,7\% (10$20 \mathrm{~cm})$ iki $0,38 \%(20-30 \mathrm{~cm})$.

Birželio mènesi, kai aplinkos temperatūra pakilo (tyrimo metu nustatyta $21{ }^{\circ} \mathrm{C}$ ), bendrosios anglies kiekis $0-10 \mathrm{~cm}$ gylyje pakilo iki $16 \%$ viso nustatyto kiekio; 10-20 cm gylyje - iki 50,4\%; 20-30 cm gylyje - iki 66,3\%. Vegetacinio periodo metu vystantis augalų šaknų sistemai ir intensyviai mineralizuojantis organinèms medžiagoms, gilesniuose sluoksniuose nustatytas didesnis bendrosios anglies kiekis. Temperatūrai krintant, organinių medžiagų skaidymosi procesai silpnejja, o temperatūrai pasiekus minusines reikšmes - sustoja.

Rugpjūčio mènesį, kai baigèsi vegetacinis periodas ir aplinkos oro temperatūra buvo $18{ }^{\circ} \mathrm{C}$, bendrosios anglies kiekis sumažejo: $0-10 \mathrm{~cm}$ gylyje $-5 \%$ nuo birželį nustatyto kiekio; $10-20 \mathrm{~cm}$ gylyje $-38,1 \%$; 20-30 cm gylyje $-39,4 \%$.

Mažèjanti aplinkos temperatūra ir didejjanti drègmè lètina netik mikroorganizmų veiklą, bet mažina ir deguonies kiekis dirvožemyje. Padidejjusios drègmès kiekis taip pat lètina anglies dioksido išsiskyrima, susidarantị yrant organinèms medžiagoms. Tačiau, esant $18{ }^{\circ} \mathrm{C}$ temperatūrai, organinių medžiagų irimo procesai nesustoja, ypač 0-10 cm gylyje. Viršutiniame dirvožemio sluoksnyje, paklo- 
tèje susikaupia dideli kiekiai mortmasès. Dalis mineralizuotos masès patenka $\mathfrak{i}$ dirvožemi, todèl $0-10 \mathrm{~cm}$ gylyje bendrosios anglies kiekis sumažejja palyginti nedaug.

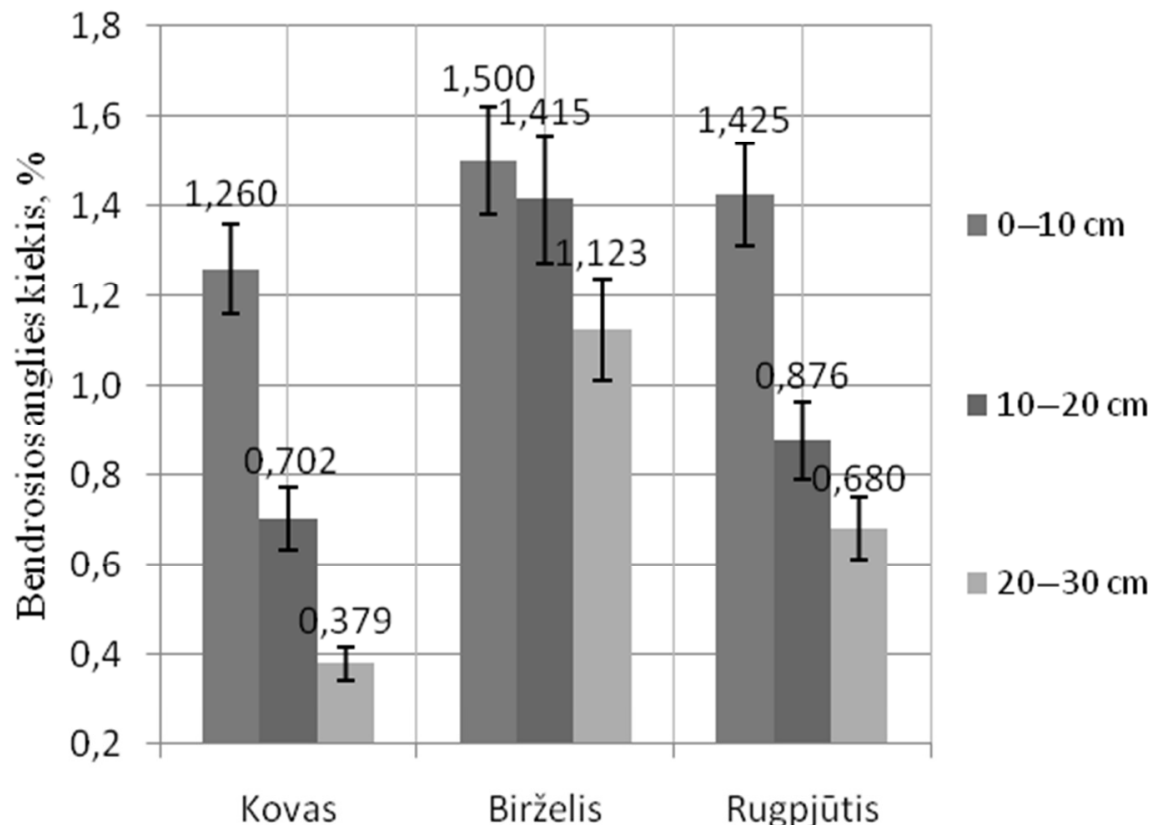

2.12 pav. Dirvožemio bendrosios anglies kiekis miško dirvožemio P tyrimo vietoje

Fig. 2.12. Soil total carbon quantity of forest soil $P$ investigation site

Bendrosios anglies kiekis, kovo mėnesi nustatytas tyrimo vietoje PA, 0$10 \mathrm{~cm}$ gylyje yra didesnis 1,3 karto; $10-20 \mathrm{~cm}$ gylyje $-2,7$ karto; 20-30 cm gylyje - 3,1 karto negu nustatytas autonominiame landšafte (2.12 pav.). Jei analizuotume bendrosios anglies kieki tik pagal gyli tai nustatyta, kad didžiausias bendrosios anglies kiekis yra $10-20 \mathrm{~cm}$ gylyje $-1,92 \% .0-10 \mathrm{~cm}$ gylyje bendrosios anglies kiekis yra 1,6\% t. y. 1,2 karto mažiau. 20-30 cm gylyje bendrosios anglies kiekis nustatytas 1,18\% t. y. 1,6 karto mažiau.

Kuomet vyksta vandens erozija viršutinis dirvožemio sluoksnis yra nuplaunamas ir susikloja pašlaitèse ar reljefo mikroịdubimuose. Dalis bendrosios anglies yra ,palaidojama“ ir kartais labai ilgam laikui „užkonservuojama“, erozijos nešmenimis padengus pašlaičių dirvožemius. 


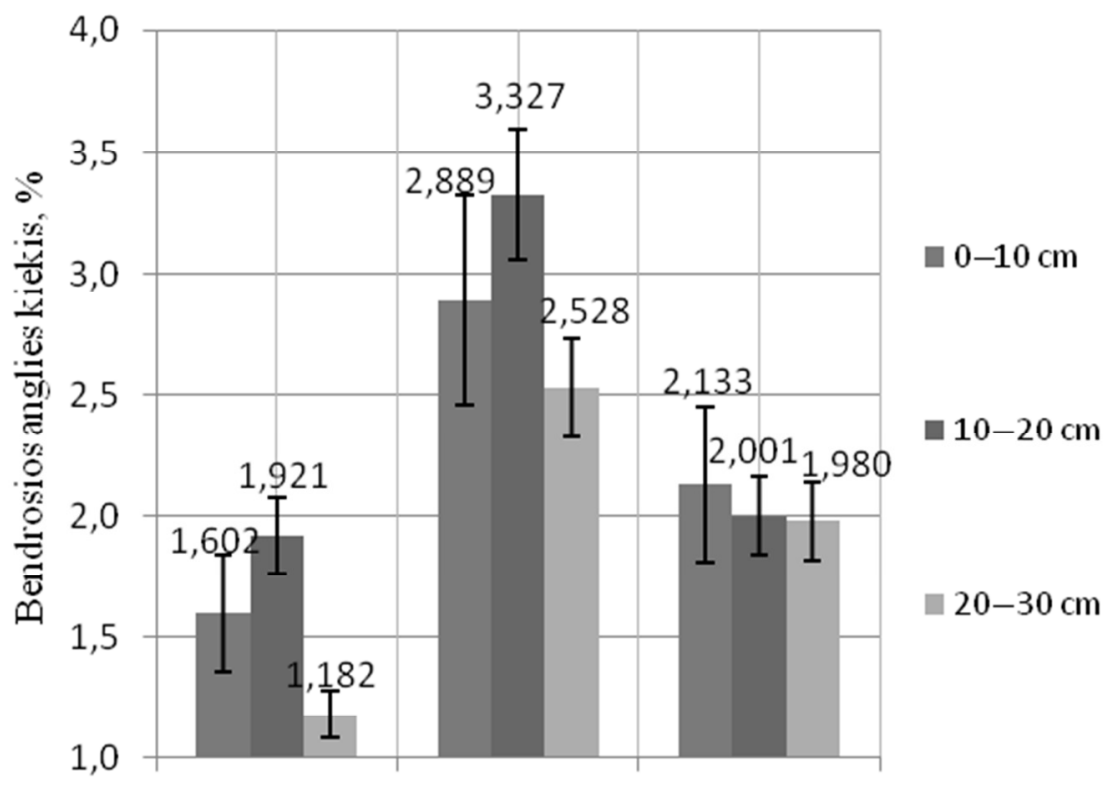

Kovas Birželis Rugpjūtis

2.13 pav. Dirvožemio bendrosios anglies kiekis miško dirvožemio PA tyrimo vieta

Fig. 2.13. Soil total carbon quantity of forest soil PA investigation site

Birželio mėnesi nustatyti bendrosios anglies kiekiai taip pat didesni nei lyginant su kovo mėnesio duomenimis. Birželio mènesį bendrosios anglies kiekis padidejo lyginant su nustatytu kovo ménesi $0-10 \mathrm{~cm}$ gylyje iki 1,8 karto, 10-20 cm gylyje 1,7 karto, o 20-30 cm gylyje iki 2,1 karto. Didžiausi bendrosios anglies kiekiai nustatyti $10-20 \mathrm{~cm}$ gylyje 3,33\%.

Rugpjūčio mènesį nukritus temperatūrai dèl sezoninio bendrosios anglies kiekio pasiskirstymo, organinių medžiagų mineralizacijos, humifikacijos ir anglies pasisavinimo biomase, bendrosios anglies kiekis PA tyrimo vietoje pasiskirstè tolygiai mažejjančia tvarka gilyn. Skirtumas tarp 10-20 ir $20-30 \mathrm{~cm}$ gylio tapo nežymus. Viršutiniame sluoksnyje bendrosios anglies kiekio nustatyta kaip ir kituose miško dirvožemiuose daugiau.

Analizuotoje tyrimo vietoje PB nustatytas bendrosios anglies kiekis didesnis, palyginti su vietomis P ir PA, dèl vandens erozijos. Suneštos organinès medžiagos èminiuose buvo daugiausia net vizualiai. Žemas gruntinio vandens lygis taip pat atliko svarbų vaidmenį bendrosios anglies kiekiui dirvožemyje. Santyki- 
nei oro drègmei padidejus per $20 \%$, prasideda anaerobiniai procesai, kurių metu anglis dirvožemyje konservuojama.

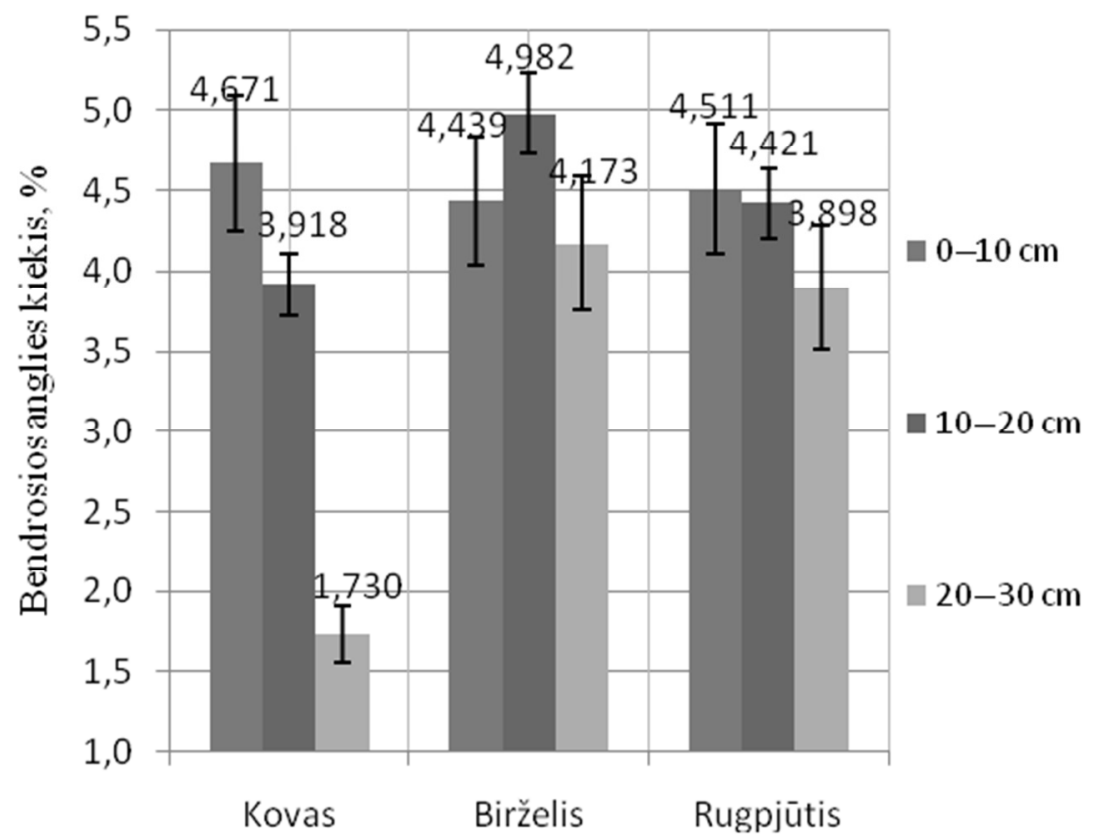

2.14 pav. Dirvožemio bendrosios anglies kiekis miško dirvožemio PB tyrimo vieta

Fig. 2.14. Soil total carbon quantity of forest soil PB investigation site

Iš atliktų tyrimu matyti, kad pavasari, nutekant sniego tirpsmo vandeniui, bendrosios anglies kiekis paviršiniame dirvožemio sluoksnyje yra net 2,7 karto didesnis negu $20-30 \mathrm{~cm}$ gylio sluoksnyje (2.14 pav.). Taip yra todèl, kad vasarą paprastai vyksta anglies perskirstymas dirvožemio profilyje, tai ir mechaninis jo dalelių iplovimas gilyn, ir tirpinimas-nusodinimas, ir naujo humuso susidarymas. Imant dirvožemio ėminius vizualiai nustatyta, kad gilesniuose sluoksniuose esamo smèlio bei žvirgždo yra žymiai daugiau, nei paviršiniuose sluoksniuose.

Be to, 20-30 cm gylyje atsirado bendrosios anglies, kurios nebuvo kovo mènesi. Bendrosios anglies kiekis šiame sluoksnyje padidèjo net 2,4 karto. Rugpjūčio mènesi bendrosios anglies kiekis $0-10 \mathrm{~cm}$ gylyje skyrèsi nuo birželio menèsi nustatyto $1,6 \%$ nuo bendro nustatyto kiekio, $10-20 \mathrm{~cm}$ gylyje $11,3 \%$, o 20-30 cm gylyje 6,6\%. Tačiau prasidejjus kovo ménesio atlydžio sezonui 
didžioji dalis bendrosios anglies kiekio 20-30 cm gylyje sumažejuo lyginant su 0-10 cm gyliu iki 2,7 karto.

Pagal atliktus Lietuvos miškų instituto tyrimus nusatatyta, kad Lietuvos teritorijoje sudaro apie $13 \%$ smèlžiamiai ir net $25-30 \%$ mišku yra pušynai. Instituto tyrimais nustatyta, kad šio tipo dirvožemiuose yra nuo $0,83 \%$ iki $1,21 \%$ humuso (Lietuvos miškų... 2010). Anglies, esančios dirvožemyje net 90 procentu sukaupiama humuse. Pagal atliktus tyrimus Neries regioniniame parke matyti, kad nustatyti bendrosios anglies kiekiai kinta nuo 1,5\% iki 4,9\%. Tačiau reikia pabrezžti, kad daugiausia bendrosios anglies nustatyta superakvalinių elementariuju geocheminių landšaftų sąlygomis, t. y. kada ryškiai pasireiškia mechaninè nuplauto nuo šlaitų humuso akumuliacija, padidinta vietinès gausios biomasès prieaugiu.

Ariamas dirvožemis. Ariamas dirvožemis išsiskiria iš kitų tuo, kad jame beveik neįmanoma atskirti horizontų, o organinès medžiagos yra susimaišiusios per visus sluoksnius. Be to, tokie dirvožemiai tręšiami tiek organinès, tiek neorganinès kilmès trąšomis. Tai įtakoja ir tyrimo rezultatus.

Tyrimų vietos M, MA ir MB pavaizduotos 2.1 paveiksle. Visos vietos buvo analizuojamo lauko centre.

Kovo mènesi tyrimo vietoje $M$ nustatytas bendrosios anglies kiekis $0-10 \mathrm{~cm}$ gylyje buvo 1,2 karto didesnis negu 10-20 cm gylyje ir 1,8 karto didesnis negu 20-30 cm gylyje. (2.15 pav.) Bendrosios anglies kiekis dirvožemyje pasiskirste tolygiai.

Birželio mėnesi vykstant augalų vegetacijai didžiausias bendrosios anglies kiekis dirvožemyje buvo nustatytas 0-10 cm gylyje $-4,413 \%$. 20-30 cm gylyje nustatytas bendrosios anglies kiekis buvo mažesnis iki 1,8 karto.

Birželị intensyviausiai vyksta mikroorganizmų veikla, jeigu tik dirvožemyje pakanka drègmès. Ypač organinių medžiagų skaidymosi procesai pagreitejja tręšiant, nes mikroorganizmai turi pakankamai mitybos medžiagų. Tai paskatina net anglies dioksido emisiją. Be to, dèl tankio ir didesnių aeracinių savybių ariamame dirvožemyje organinès medžiagos greičiau mineralizuojasi. Tačiau susikaupęs anglies kiekis ariamame dirvožemyje būna mažiausias, nes šis dirvožemis yra veikiamas ne tik vejjo, bet ir vandens erozijos. Rytinèse Lietuvos regionuose sniego dangos tyrimais nustatyta, kad nuo ariamo dirvožemio nupustoma iki $11 \mathrm{t} \mathrm{ha}^{-1}$ dirvožemio, kurio dalelių dydis iki $1 \mathrm{~mm}$ (Bundiniené $2002,2000,1998$ ). Taip pat nustatyta, kad auginant daugiametes svidres bei dobilus organinès anglies kiekis dirvožemyje nežymiai padidèja. Analizei buvo imti glejjiškieji jauražemiai, kuriuose organinès anglies kiekis kito nuo 4,68\% iki $5,36 \%$. 


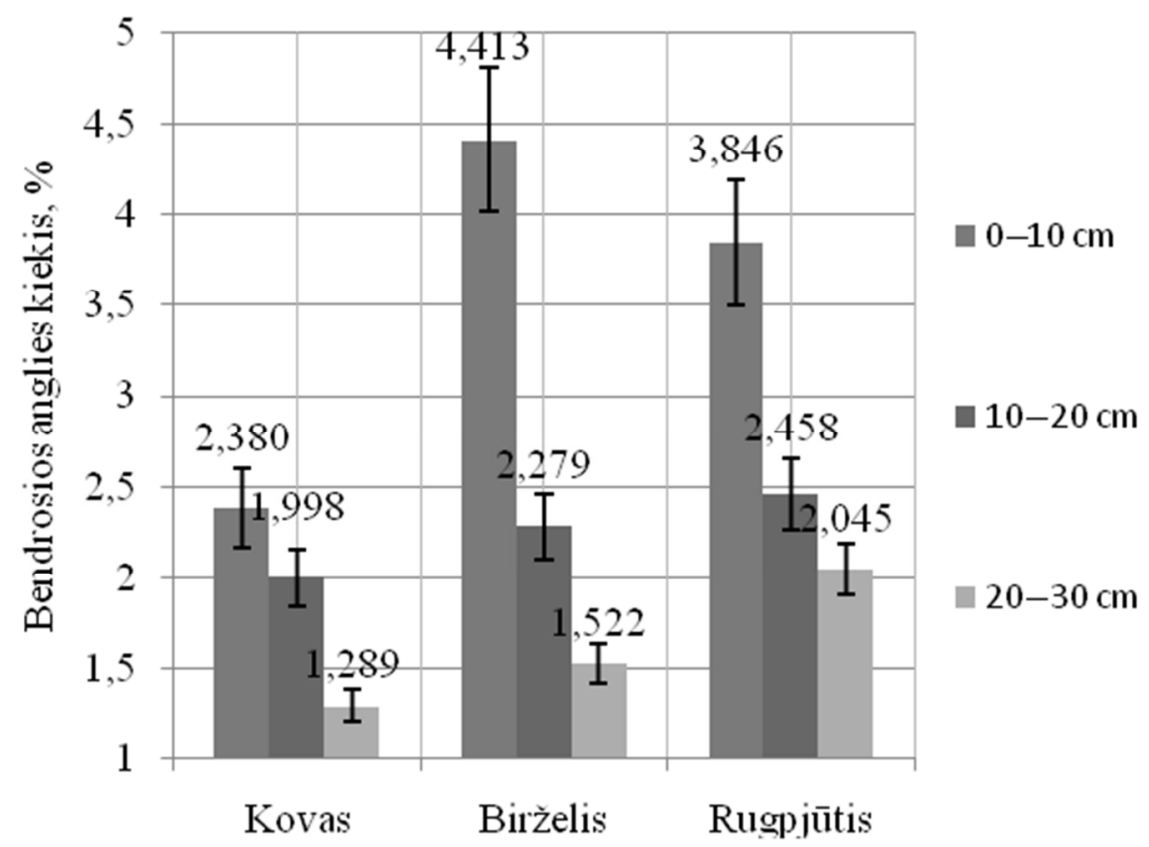

2.15 pav. Dirvožemio bendrosios anglies kiekis ariamo dirvožemio M tyrimo vieta

Fig. 2.15. Soil total carbon quantity of arable soil $M$ investigation site

Tyrimą vietoje $M$ atliekant rugpjūčio mènesi, dirvožemis jau buvo suartas. Tyrimo duomenys rodo, kad arimas daro didelę įtaką bendrosios anglies kiekio pasiskirstymui: skirtumas tarp visų trijų analizuojamų gylių buvo sumažejęs. Ryškiai didesnis išliko tik 0-10 cm gylio rodiklis; skirtumas tarp kitu analizuojamų gylių buvo palyginti mažas. Jei palygintume su birželio mènesio gautais duomenimis tai bendrosios anglies kiekis padidejo $0-10 \mathrm{~cm}$ gylyje net iki 1,8 karto lyginant su kovo ménesiu.

Ryškiausią bendrosios anglies kiekio kitimą ariamame dirvožemyje atspindejo tyrimo vieta MA. Kovo mènesi bendrosios anglies kiekis $0-10 \mathrm{~cm}$ gylyje čia buvo didesnis, palyginti su birželio mènesio duomenimis. Jeigu lygintume tyrimo vietų $M$ ir $\mathrm{MA}$ rodiklius, tai matytume, $\mathrm{kad} 0-10 \mathrm{~cm}$ gylyje vidutinis bendrosios anglies kiekis buvo: vietoje $\mathrm{M}-3,55 \%$; vietoje $\mathrm{MA}-1,76 \%$ (2.16 pav.). 


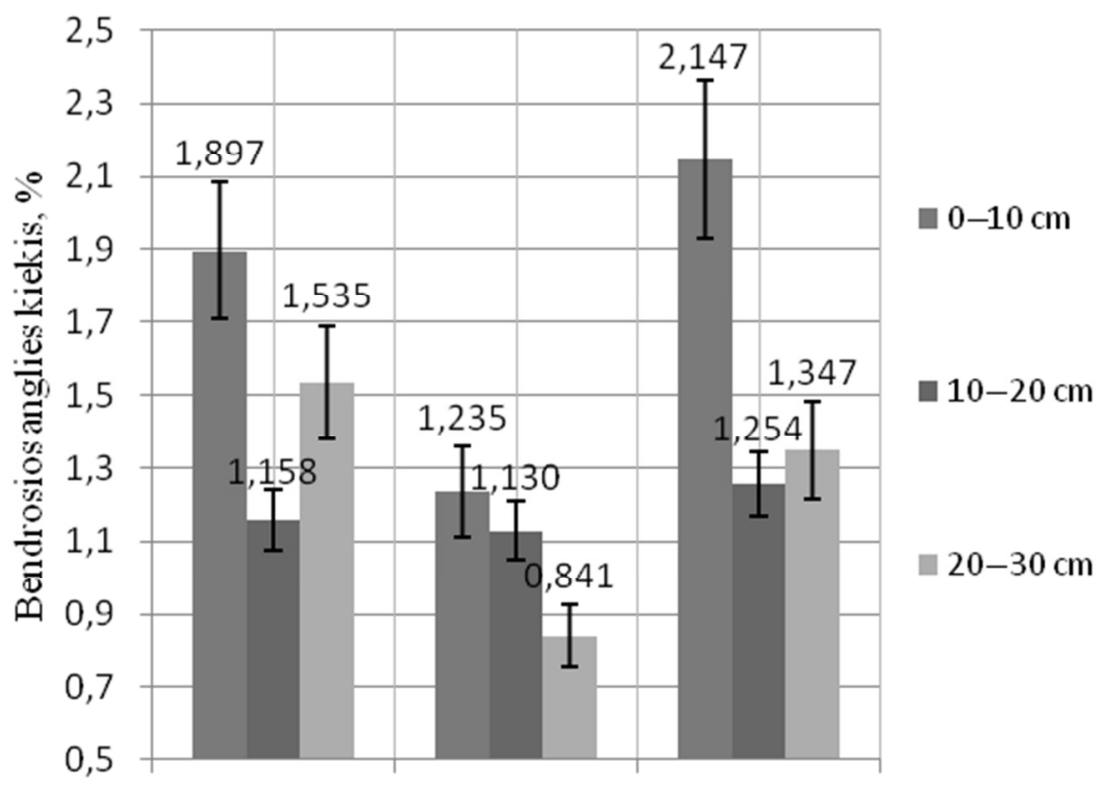

Kovas Birželis Rugpjūtis

2.16 pav. Dirvožemio bendrosios anglies kiekis ariamo dirvožemio MA tyrimo vieta

Fig. 2.16. Soil total carbon quantity of arable soil MA investigation site

Bendrosios anglies tyrimams didelę itaką daro lauko tręšimas organinès kilmès trąšomis. Tai lemia duomenų netolygumą. Tyrimo vietoje MA nustatyta, kad 10-20 cm gylyje per visą analizès laikotarpi bendrosios anglies kiekis keitèsi palyginti mažai ir svyravo apie 1,18\%. 20-30 cm gylyje bendrosios anglies kiekis kito daugiau, bet irgi palyginti nežymiai: vidutinė jo reikšme $\sim 1,24 \%$.

Tiriant ploto MB èminius nustatyta, kad bendrosios anglies kiekis kovo mènesi $0-10 \mathrm{~cm}$ gylyje buvo $0,88 \% ; 10-20 \mathrm{~cm}$ gylyje $-0,93 \% ; 20-30 \mathrm{~cm}$ gylyje $0,93 \%$ (2.17 pav.).

Atlikus bendrosios anglies tyrimus birželio mènesi, duomenys gauti daug didesni: $0-10 \mathrm{~cm}$ gylyje bendrosios anglies kiekio reikšmès nuo pavasario padidejo 2,3 karto; 10-20 cm gylyje - 2 kartus; 20-30 cm gylyje - 1,5 karto. Pasiskirstymas pagal gyli, palyginti su kovo mènesiu, buvo tolygus. Be to, kovo ménesi dirvožemis nebuvo tręštas.

Rugpjūti gauti duomenys parode, kad bendrosios anglies kiekio pasiskirstymas pagal gyli išliko tolygus: reikšmès kinta nuo $0,89 \%$ iki $1,43 \%$, o palyginus gautas reikšmes su birželio ménesiu nustatyta, kad 0-10 cm gylyje bendro- 
sios anglies kiekis buvo 1,4 karto didesnis nei rugpjūčio mènesị. 20-30 cm gylyje bendrosios anglies pokytis tarp birželio ir rugpjūčio mènesių buvo 1,5, o 20 $30 \mathrm{~cm}$ gylyje 1,6 karto. Iš atliktu tyrimų matyti, kad bendrosios anglies kiekio pasiskirstymas tiek pačiame lauke tiek pagal gylius yra labai ịvairus. Tokiai duomenų sklaidai turejjo itakos netik arimas, bet ir tręšimas, kuris buvo netolygus.

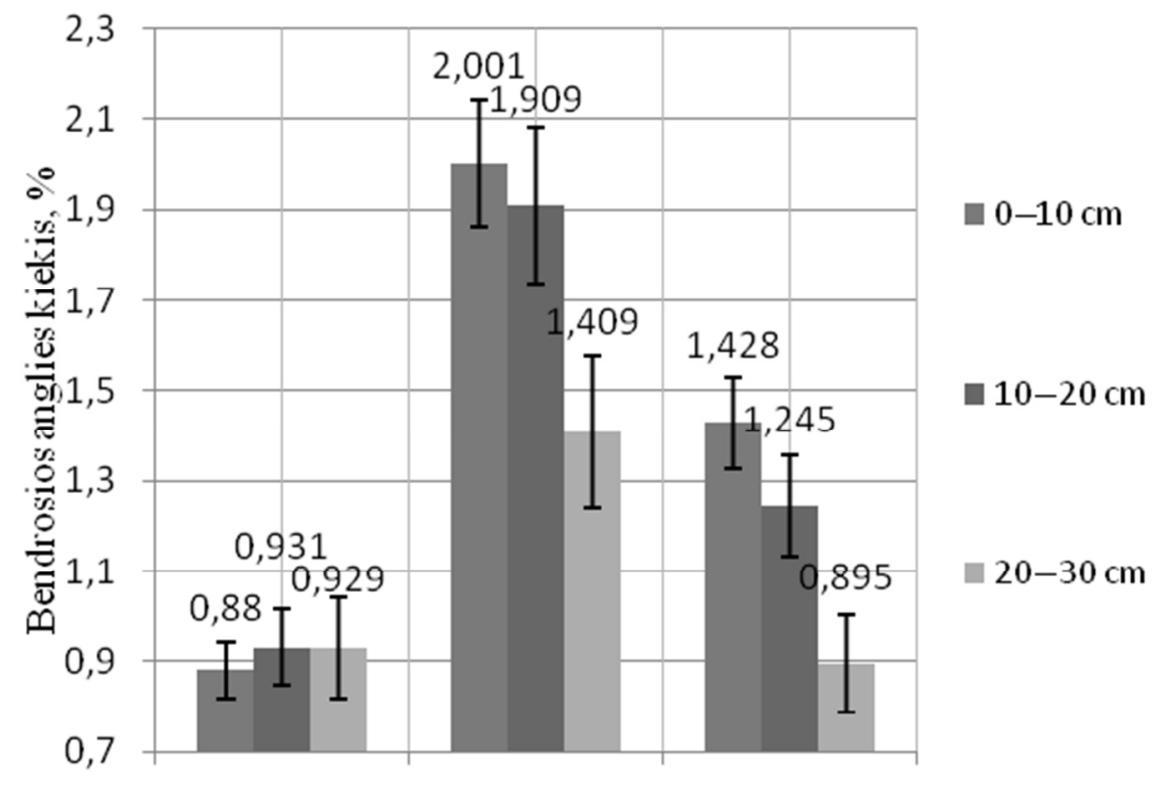

Kovas Birželis Rugpjūtis

2.17 pav. Dirvožemio bendrosios anglies kiekis ariamo dirvožemio MB tyrimo vieta

Fig. 2.18. Soil total carbon quantity of arable soil MB investigation site

Teigiama, jog žemès dirbimo būdas lemia $\mathrm{CO}_{2}$ emisiją tokiu mastu, kokiu gyliu ir intensyvumu yra mechaniškai dirbama žemè. JAV nustatyta, kad dirvas giliai ariant $\mathrm{CO}_{2}$ emisija siekia $134 \%$, jas tik lèkščiuojat - 58, o taikant tiesioginę sèją - vos $27 \%$. i dirvą iterptu augalų turimo anglies kiekio. Tai rodo, kad intensyvus žemès dirbimas tiesiogiai didina $\mathrm{CO}_{2}$ emisiją. Skirtingais skaičiavimais, vidutinio klimato sąlygomis ne mažiau kaip 15-25 $\mathrm{tha}^{-1}$ mèšlo, iskaičiuojant ir lauke paliekamas augalų liekanas, turi būti įterpiama į dirvą, kad atsistatytų anglies nuostoliai dèl dirvų arimo. Taip pat nustatyta, kad $\mathrm{CO}_{2}$ emisija iš dirvožemio yra proporcinga mechaniškai supurento dirvožemio tūriui. Suarus 
dirvą $28 \mathrm{~cm}$ gyliu, $\mathrm{CO}_{2}$ emisija siekè $2,445 \mathrm{~g} \mathrm{CO}_{2} \mathrm{~m}^{-2}$, o 20,15 ir $10 \mathrm{~cm}$ - atitinkamai 1,939, 1,588 ir $891 \mathrm{~g} \mathrm{CO}_{2} \mathrm{~m}^{-2}$ (Žemès dirbimo... 2010).

Ariamo dirvožemio duomenis palyginus su kitais analizuotais dirvožemiais nustatyta, kad bendrosios anglies kiekis dirvožemyje išsiskyre tik M plotas. MA ir MB plotuose nustatytas bendrosios anglies kiekis yra mažiausias lyginant su kitų dirvožemių autonominiais landšaftais. Kovo mėnesį vidutinès ariamo dirvožemio reikšmès buvo mažesnès už miško dirvožemio bendrosios anglies kieki iki 1,5 karto, o su pievos dirvožemiu iki 1,2 karto. Birželio mènesi bendrosios anglies kiekiai ariamame dirvožemyje padidèjo, tačiau jie buvo mažesni 1,2 karto nei miške ir pievoje. Rugpjūčio mènesi bendrosios anglies kiekis ariamame dirvožemyje buvo iki 1,1 karto mažesnis nei miško dirvožemyje ir 1,2 karto mažesnis nei pievos dirvožemyje.

Pievos dirvožemis. Pievos dirvožemis buvo analizuojamas senose pievose, kurios dažnai nešienaujamos. Tokiose pievose po augalų danga, viršutiniame dirvožemio sluoksnyje, susiformuoja sudžiūvusių augalinių liekanų. Tyrimais nustatyta, kad pievose esančios pernykštès žolès liekanos mineralizuojasi apytiksliai per trejus metus. Analizei parinktos penkios tyrimo vietos. Trijose vietose buvo analizuojama reljefo itaka bendrosios anglies kiekio pokyčiams, o dvi vietos buvo lygioje pievoje.

Bendrosios anglies kiekio tyrimo vieta EB priklauso superakvaliniam landšaftui (2.18 pav.). Bendrosios anglies kiekis kovo ménesị buvo didesnis, palyginti su birželio ir rugpjūčio mènesiais. $0-10 \mathrm{~cm}$ gylyje šis kiekis kovą buvo 1,5 karto didesnis negu nustatytas birželị ir 1,4 karto - negu nustatytas rugpjūtị. Bendrosios anglies kiekis per visą tyrimo laikotarpi $0-10 \mathrm{~cm}$ gylyje sumažèjo $1,074 \% ; 10-20 \mathrm{~cm}$ gylyje padidejo $0,771 \%$.

Anglies kiekis dirvožemio $10-20 \mathrm{~cm}$ sluoksnyje kovo mėnesi buvo 1,4 karto mažesnis negu birželio mènesị ir 1,6 karto mažesnis, negu rodo rugpjūčio tyrimų duomenys. Birželio ir rugpjūčio mènesiais bendrosios anglies kiekio kitimas artimas, todèl galima daryti prielaida, kad vasarą pusiausvyra dirvožemyje išlieka.

20-30 cm gylyje bendrosios anglies kiekis birželio mènesi buvo 1,4 karto mažesnis negu kovo ir 1,25 karto mažesnis negu rugpjūčio mènesị. Iš gautų duomenų matyti, kad bendrosios anglies kiekio kitimas analizuojamuose gyliuos panašus, mažiausias kitimas yra 20-30 cm gylyje.

Analizuojamoje tyrimo vietoje $\mathrm{E}$ bendrosios anglies kiekio kitimo tendencijos artimos pievos dirvožemio EB èminiams. (2.19 pav.) Pievos tyrimo vieta EA, esanti autonominiame landšafte, yra arčiausiai superakvalinio landšafto. Bendrosios anglies kiekis $0-10 \mathrm{~cm}$ gylyje, pagal tyrimo E duomenis, kovo ménesi buvo 1,4 karto didesnis negu birželio ir 1,05 karto didesnis negu rugpjūčio mènesi - taigi, tiriamuoju laikotarpiu sumažèjo. Vèl galima daryti prielaidą, kad organinès medžiagos pievos dirvožemyje skaidosi tik pasibaigus rugpjūčio mè- 
nesiui, todèl tik atlikus tyrimą žiemos pradžioje galima sužinoti bendrosios anglies kieki.

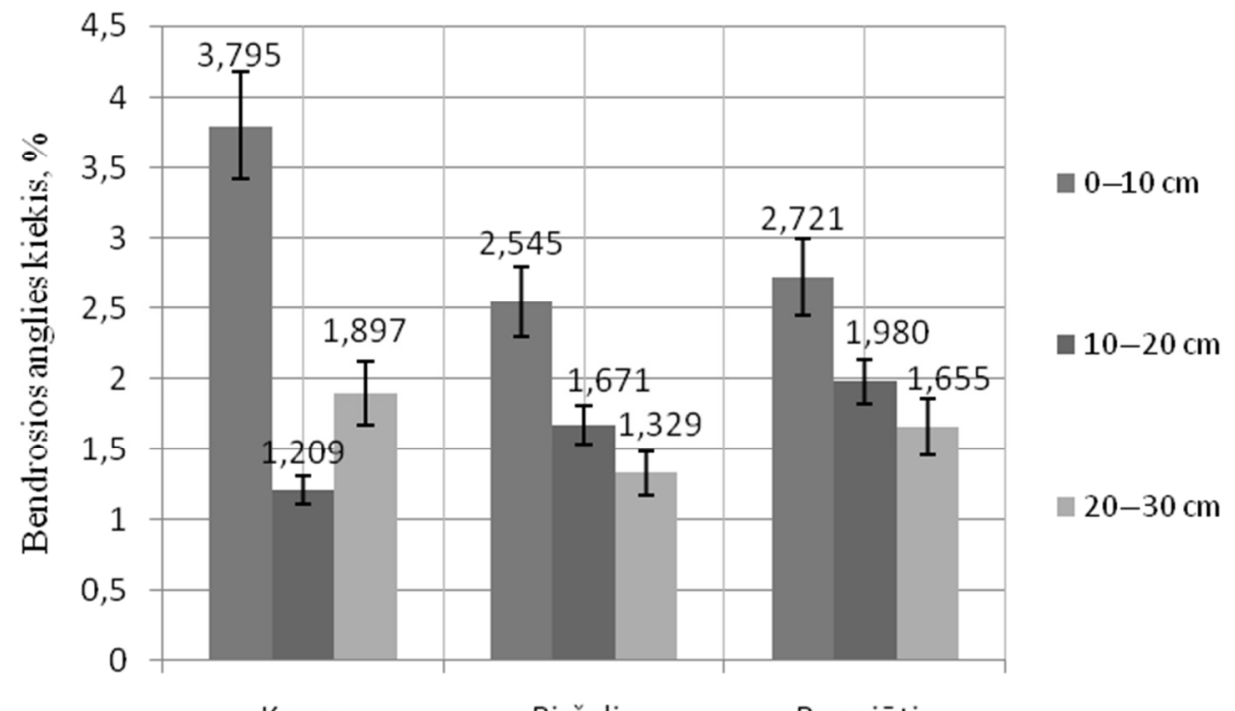

2.18 pav. Dirvožemio bendrosios anglies kiekis pievos dirvožemio EB tyrimo vieta

Fig. 2.18. Soil total carbon quantity of meadow soil EB investigation site

10-20 cm gylyje pastebima neryški mažèjimo tendencija: nuo kovo mènesio bendrosios anglies kiekis, birželio ir rugpjūčio tyrimų duomenimis, buvo sumažejęs atitinkamai 1,1 ir 1,15 karto. Tai ganètinai mažas kitimas: nuo pavasario iki pirmo vasaros ménesio - tik $0,148 \%$, iki paskutinio vasaros ménesio $0,201 \%$. Ypač šis pokytis menkas antruoju stebejjimo laikotarpiu: per vasarą bendrosios anglies kiekis viduriniame pievos gylyje tepakito 1,05 karto.

20-30 cm gylyje bendrosios anglies kiekis taip pat liko mažai pakitęs: vasaros mènesiais jis sumažejo 1,057-1,084 karto, palyginti su kovo mènesio duomenimis.

Pastarojo tyrimo duomenis lyginant su EB, matyti, kad bendra tendencija pievų dirvožemyje panaši, nors tyrimo vietoje EB nuo birželio iki rugpjūčio bendrosios anglies kiekis didejo. 


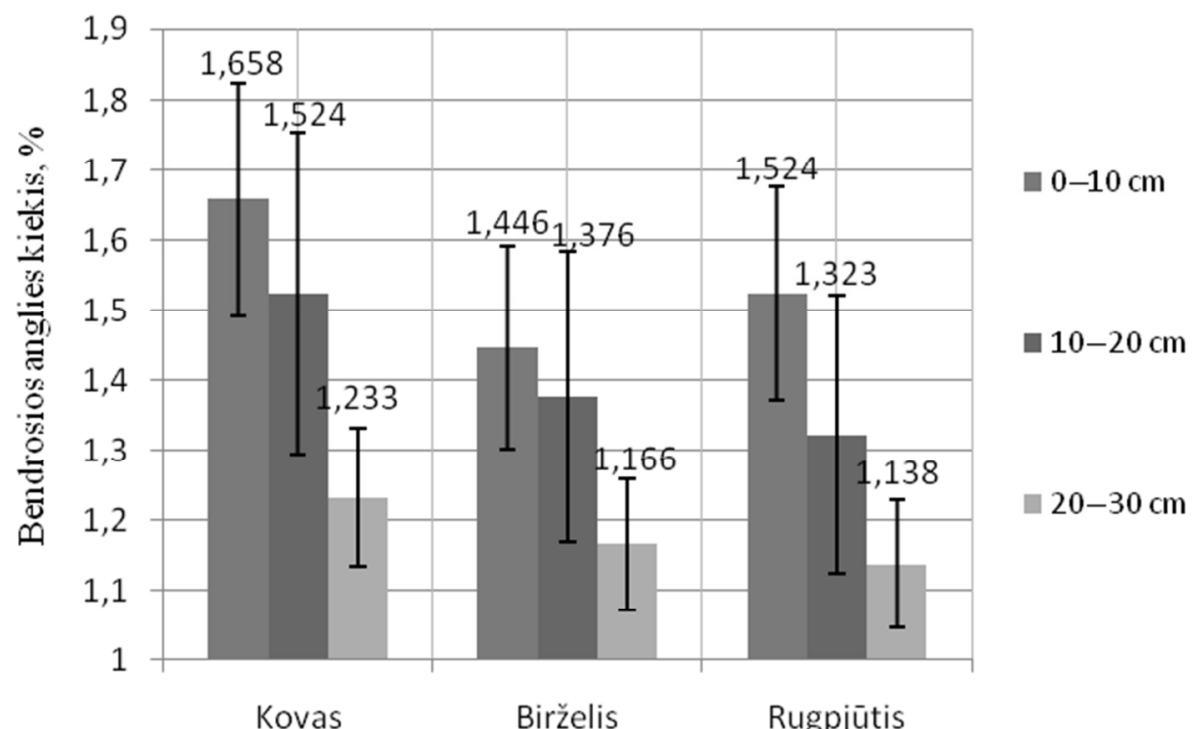

2.19 pav. Dirvožemio bendrosios anglies kiekis pievos dirvožemio E tyrimo vieta

Fig. 2.19. Soil total carbon quantity of meadow soil E investigation site

Analizuojant tyrimo vietą EA, kuri išskirtinai priklauso autonominiam landšaftui, nustatyta, kad bendrosios anglies kiekis pievos dirvožemyje kinta pagal miško ir ariamo dirvožemio tendencijas (2.20 pav.). Kovo mènesi nustatytas bendrosios anglies kiekis čia buvo gerokai mažesnis negu vasaros metu: 0-10 $\mathrm{cm}$ gylio èminio rodiklis nuo kovo iki birželio mènesio padidejo 2,2 karto $(0,796 \%)$; nuo kovo iki rugpjūčio mènesio - 2,5 karto. Kiek mažesnis padidejjimas nustatytas lyginant birželio ir rugpjūčio tyrimų duomenis $-0,129 \%$. Nors pastaruoju laikotarpiu bendrosios anglies kiekis didejo nežymiai, vis dèlto didèjimas užfiksuotas abiem analizuojamais laikotarpiais. Tuo tarpu miško ir ariamo dirvožemio bendrosios anglies kiekis didejjo tik pirmuoju tyrimo laikotarpiu, o antruoju - iki rugpjūčio, šiek tiek sumažeja.

10-20 cm gylyje tiriamuoju laikotarpiu bendrosios anglies kiekis nuo kovo ménesio padidejo 2,5-2,8 karto; 20-30 cm gylyje kovo ménesi buvo 2 kartus mažesnis negu birželị ir 2,1 karto mažesnis negu rugpjūtị. Lyginant pievų dirvožemi, bendrosios anglies kiekis autonominio landšafto vietose kinta apie $1,5 \%$, o superakvalinio landšafto - net iki 3,795\%. 


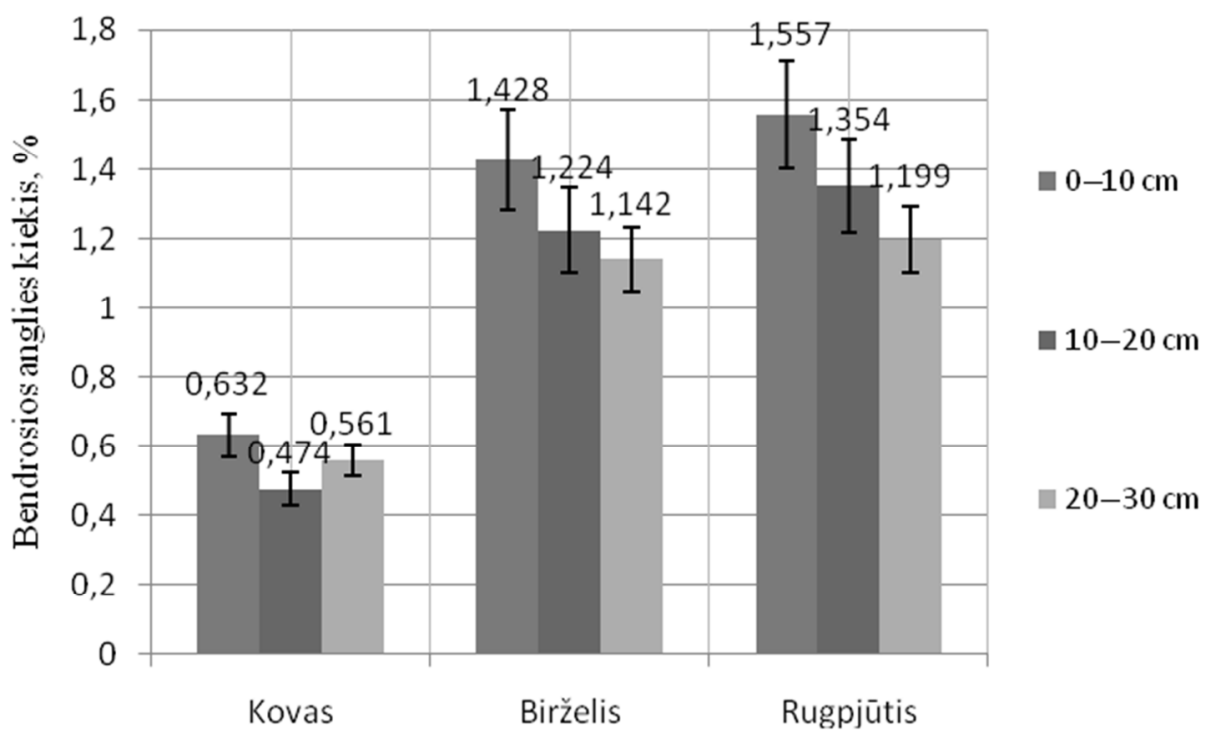

2.20 pav. Dirvožemio bendrosios anglies kiekis pievos dirvožemio EA tyrimo vieta

Fig. 2.20. Soil total carbon quantity of meadow soil EA investigation site

Analizuojant pievos dirvožemi, paimtą iš tyrimo vietų KA ir K, bendrosios anglies kiekis buvo gautas artimas EB rodikliams, tačiau kitimo tendencijomis labiau paněšejo i miško bei ariamą dirvožemius. Grafikas KA rodo nežymią bendrosios anglies sumažejjimo tendenciją per visą tiriamą laikotarpi $0-10 \mathrm{~cm}$ gylyje (2.21 pav.). Tačiau tas sumažejjimas ganètinai nežymus - tik $0,134 \%$. Didžiausias bendrosios anglies kiekis šiame pievos dirvožemyje buvo susikaupęs birželi - 1,1 karto didesnis negu kovą ir 1,14 karto didesnis negu rugpjūti.

20-30 cm gylio duomenimis, abiem laikotarpiais nustatytas bendrosios anglies kiekio augimas, tačiau jo tempas lètas - tik $0,243 \%$ per visą tiriamą laikotarpi. Analizuojama pievos vieta priklauso superakvaliniam landšaftui, skirtingai negu vieta L, kuri yra autonominiame landšafte.

20-30 cm gylyje bendrosios anglies kiekis tyrimo vietoje $\mathrm{K}$ kito tik didejimo kryptimi (2.22 pav.). Iš ėminio vietos nustatyta, kad tai - buvusi užliejama pieva: dèl nešmenų bendrosios anglies kiekis sluoksniuojasi ir metai po metų susidaro sluoksniai su organiniais intarpais. 


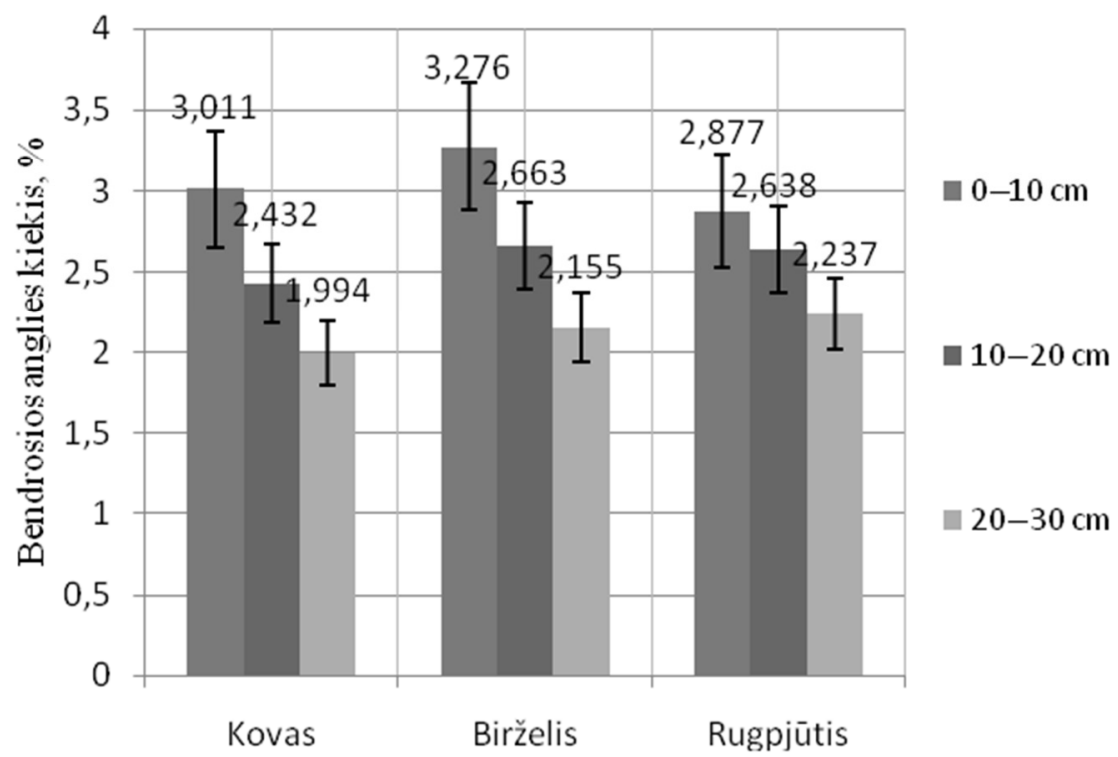

2.21 pav. Dirvožemio bendrosios anglies kiekis pievos dirvožemio KA tyrimo vieta

Fig. 2.21. Soil total carbon quantity of meadow soil KA investigation site

Tyrimo vietos KA ir K buvo parinkti autonominiame landšafte, kuris išsiskiria dirvožemio struktūra: pievose E, EA ir EB vyravo stambus žvirgždas, o imant $\mathrm{K}$ ir L dirvožemio nustatyta humusingų intarpų.

Lyginant $0-10 \mathrm{~cm}$ gylio duomenis, nustatyta, kad autonominio landšafto miško dirvožemyje bendrosios anglies kiekis kovą buvo 1,26\%, o to paties landšafto pievos dirvožemyje $0,6-1,6 \%$. Iš $10-20 \mathrm{~cm}$ gylio èminių miško dirvožemyje bendrosios anglies nustatyta $0,7 \%$, o pievos $1,2-1,5 \%$. $20-30 \mathrm{~cm}$ gylio duomenys parodè, kad miško dirvožemyje bendroji anglis sudaro $0,38 \%$, pievos $1,2-1,9 \%$. Taigi, miško dirvožemyje kovo ménesi bendrosios anglies buvo žymiai mažiau negu pievos dirvožemyje. Birželio mènesị bendrosios anglies kiekis 0-10 cm gylyje pievos dirvožemyje taip pat buvo didesnis.

Analizuojat kitus gylius, nustatyta, kad pievos dirvožemio plote EB bendrosios anglies kiekiai didesni negu miško dirvožemyje. Rugpjūčio mènesi autonominio landšafto pievos dirvožemis pagal bendrosios anglies kiekius pranoko miško dirvožemi. Tačiau, tiriant dirvožemio èminius, kuriems didelę itaką dare reljefas, paaiškejjo, kad didesni bendrosios anglies kiekiai yra miško dirvožemyje. 
Tik paviršiniame $0-10 \mathrm{~cm}$ pievos dirvožemio sluoksnyje bendrosios anglies buvo iki 2,2 karto daugiau negu miško. Analizuojant gilesnius sluoksnius, nustatyta, kad miško dirvožemyje dèl reljefo itakos bendrosios anglies kiekis didesnis iki 1,1 karto. Tokiems skirtumams didelę itaką daro nuokritos ir jų irimo greitis. Moksliniais tyrimais nustatyta, kad lapai ir kitos nesumedejusios augalinès kilmès medžiagos dirvožemio paviršiuje suyra apytikriai per 1,5 metų. Tuo tarpu sumedejjusios augalinès kilmès medžiagos (šakos, smulkios šakelès) yra daug léčiau - jų irimo greitis siekia iki 7 metų.

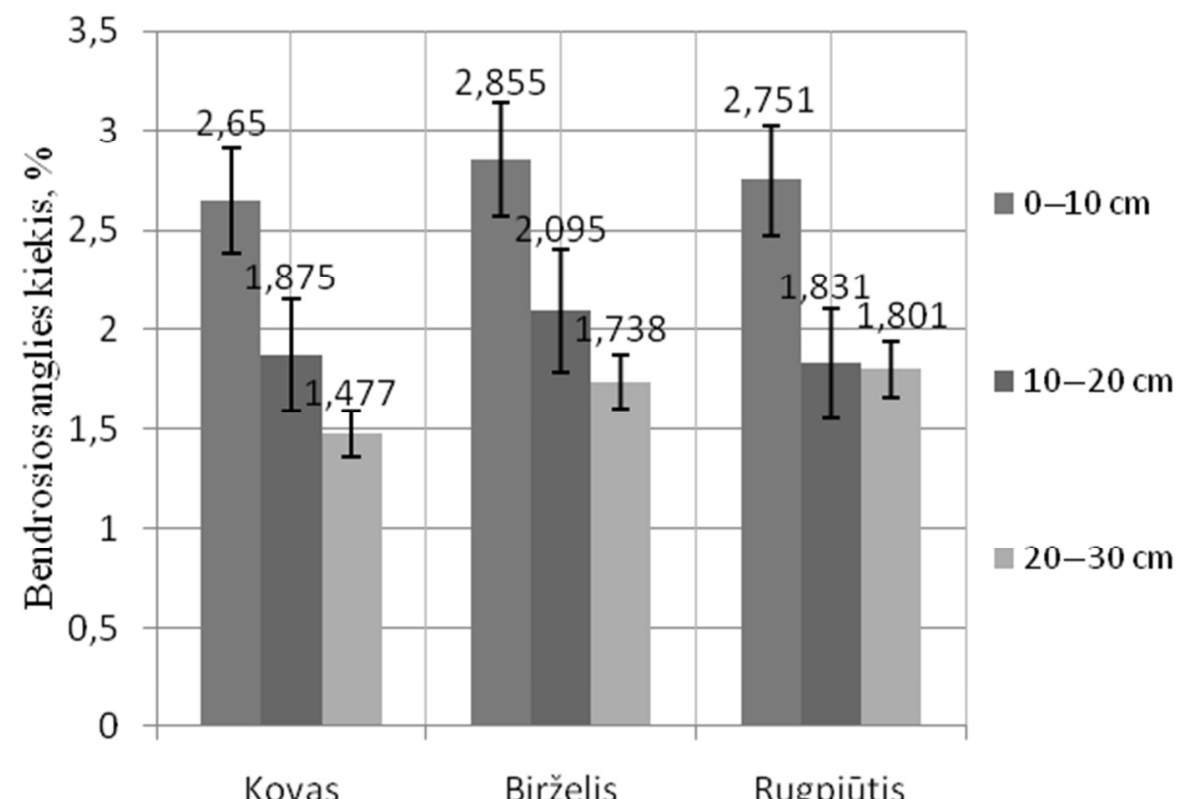

2.22 pav. Dirvožemio bendrosios anglies kiekis pievos dirvožemio K tyrimo vieta

Fig. 2.22. Soil total carbon quantity of meadow soil $\mathrm{K}$ investigation site

Iš superakvalinio landšafto duomenų nustatyta, kad bendrosios anglies kiekiai didžiausi miško dirvožemyje. Išsiskiria tik kovo menesio duomenys, ir tik $20-30 \mathrm{~cm}$ gylyje. Kituose gyliuose ir kitais analizuotais menesiais bendrosios anglies kiekiai miško dirvožemyje buvo didesni iki $\sim 1,6$ karto. Šie duomenys patvirtina reljefo itaką bendrosios anglies kiekiui ir tai, kad miško dirvožemyje bendrosios anglies susikaupia daugiau.

Pievos tyrimo duomenis lyginant su kitų mokslininkų gautais duomenimis, nustatyta, kad daugiameteje pievoje Joniškèlio tyrimo stotyje organinès anglies 
kiekis kito nuo 2,76\% iki 3,75\%. Daugiausiai organinès anglies aptikta plote, kuriame vyrauja paprastujų motiejuku kultūros (Liaudanskienè 2010). Todèl daroma prielaida, kad smilginiai augalai, turintys kuokštinę šaknų sistema, pasižymi didesnèmis galimybėmis kaupti angli dirvožemyje.

Ariamas dirvožemis. Tiriant bendrosios anglies kieki ariamame dirvožemyje, $0-10 \mathrm{~cm}$ gylyje rugpjūčio mènesi nustatyti rodikliai $0,755 \%$ pranoko kovo mènesio rodiklius. Birželi bendrosios anglies buvo sukaupta 0,076 karto daugiau negu kova. 10-20 cm gylyje tiriamuoju laikotarpiu nustatytas bendrosios anglies kiekio padidejjimas iki 0,38 karto. Rugpjūčio mènesio èminiuose bendrosios anglies kiekis buvo padidèjęs 0,290\%. Birželio ménesio duomenimis, jis buvo $0,120 \%$ didesnis, palyginti su rugpjūčio. Tačiau $20-30 \mathrm{~cm}$ gylyje bendrosios anglies sumažejo: rugpjūčio èminiuose jos buvo nustatyta $0,172 \%$ mažiau ir 1,63 karto mažiau, palyginti su kiekiu, nustatytu 10-20 cm gylyje.

Miško dirvožemis. Miško dirvožemyje visuose tyrinètuose gyliuose nustatytas bendrosios anglies kiekio padidejimas: $0-10 \mathrm{~cm}$ gylyje $-0,179 \% ; 10-20$ cm gylyje $-0,252 \%$ (1,41 karto); $20-30 \mathrm{~cm}$ gylyje akivaizdus $-1,089 \%$. Birželio mènesi bendrosios anglies kiekis buvo didesnis negu rugpjūčio atitinkamai pagal gyli: 0,253\% (0-10 cm); 0,809\% (10-20 cm);0,422\% (20-30 cm gylyje).

Pievos dirvožemis. Pievos dirvožemyje $0-10 \mathrm{~cm}$ gylyje nustatytas bendrosios anglies sumažèjimas, iki 0,094\%. Tačiau 10-20 cm gylyje bendrosios anglies kiekis birželio ménesi buvo didesnis net 5,12 karto, arba 0,483\%. 20-30 cm gylyje pirmą vasaros mènesi bendrosios anglies kiekis tik 0,21 karto pranoko kovo mènesio duomenis $-0,1 \%$ padidejo. Taip pat nustatyta, kad birželio mènesi bendrosios anglies mažiau negu rugpjūti buvo visuose analizuojamuose gyliuose: $0,128 \%(0-10 \mathrm{~cm}) ; 0,128 \%(10-20 \mathrm{~cm}) ; 0,118 \%(20-30 \mathrm{~cm}$ gylyje). Analizuojant kitu pievos èminių duomenis, $0-10 \mathrm{~cm}$ gylyje taip pat nustatytas bendrosios anglies sumažejimas - jis sudaro $0,016 \%$. Tačiau birželio mènesi anglies buvo padaugeję nuo $0,251 \%(0-10 \mathrm{~cm})$ iki $0,145 \%(10-20 \mathrm{~cm}) \cdot 20-30$ $\mathrm{cm}$ gylyje pirmą vasaros mėnesį bendrosios anglies kiekis $0,072 \%$ buvo mažesnis negu rugpjūčio mènesị.

Lietuvos agrarinių tyrimų centro tyrimais nustatyta, kad dirvožemio panaudos tyrimo aikštelèse per visą tyrimo laikotarpi nuosekliai mažejo org. C kiekis: po pirmuju 5 tyrimų metų - vidutiniškai $24 \%$; po 10 metų - net $38 \%$ nuo pradinio lygio $(0,98 \%$ org. C). Skirtumai tarp aikštelių labiausiai išryškejjo $1999 \mathrm{~m}$. $(0,22 \%$ org. C): jauno pušyno aikštelès dirvožemyje sumažejimas buvo $\sim 0,1 \%$, o vienoje iš pievos aikštelių (II Pa) - net $0,33 \%$. Per kitus 5 metus anglies mineralizacija suletejo ir $2004 \mathrm{~m}$. org. C kiekis bandymo aikštelèse tesiekè vidutiniškai $0,6 \%( \pm 0,14 \%)$. Lygiagrečiai šiems pokyčiams beveik visose tyrimu aikštelèse atvirkščiai kito bendrojo N kiekis. Per 10 metų lauko sejjomainos aikštelejje $\mathrm{N}$ pagausèjo $\sim 22-31 \%$; liucernos dirvožemyje $\sim 63-66 \%$ (abiem atvejais labiau - 
tręštuose plotuose); dirvone - 34\%. Nors dirvožemių renatūralizacija - vienas iš kelių būdų pagausinti ar bent palaikyti organinių medžiagų kiekį dirvožemyje, nurodoma, kad tai palyginti lètas šių medžiagų akumuliacijos procesas.

Ivairiose stacionariose aikštelèse per 10 metų dèl žemėnaudos skirtumų susiformavusios fitocenozės nežymiai skyrèsi agrocheminiais rodikliais: org. C skirtumai siekè $0,14 \%$; bendrojo $\mathrm{N}-0,024 \%$; $\mathrm{C} / \mathrm{N} \sim 1,30$ vnt. Taigi, skirtingai negu teorinè prielaida, kad org. $\mathrm{C}$ turi akumuliuotis renatūralizuojamame dirvožemyje, per visus 10 tyrimo metų org. C dirvožemyje mažejo. Dešimtais tyrimo metais (2004 m.) mažiausiai org. C ir bendrojo $\mathrm{N}$ buvo nustatyta jauno pušyno (IV Mk) aikštelèje; daugiausiai - brandaus miško (V Mb) aikšteleje; ten pat nustatytas ir didžiausias $\mathrm{C} / \mathrm{N}-15,2$ vnt. Tyrimo pradžioje lauko sejjomainos vietoje C/N buvo 12-14/1 ir atitiko teorini natūraliai rūgštaus pakalkinto dirvožemio kiekị; per dešimtmetị šis santykis beveik pasieke 4/1, kai intensyviai skaidoma organinè medžiaga ir išsiskiria daug $\mathrm{NH}_{3}$ (Saulius 2007).

Skirtingų bioklimatinių zonų dirvožemiuose labai skiriasi tiek medžiagų balanso pajamų, tiek išlaidų dalys. Pavyzdžiui, anglies, turinčios augalinių liekanų, i dykumų dirvožemi patenka $<1000 \mathrm{~kg} \mathrm{ha}^{-1}$, drègnų atogrąžų miškuose $>14000$ $\mathrm{kg} \mathrm{ha}^{-1}$; mikroorganizmų sujungto (fiksuoto) azoto kiekis ivvairių gamtinių zonų dirvožemiuose gali būti įvairus - nuo 10 iki $5000 \mathrm{~kg} \mathrm{ha}^{-1}$; medžiagų nuostoliai dèl paviršinio nuotèkio - nuo 0 iki $300 \mathrm{~kg} \mathrm{ha}^{-1}$.

Ypač svarbios biogeninès medžiagos dirvodaros maisto medžiagų balansui, nes augalai i biologinę apykaitą itraukia ir gražina i dirvožemị elementų kelis kartus daugiau, palyginti su tuo, kiek jų patenka i dirvožemị ir iš jo pašalinami abiogeniškai. Pavyzdžiui, juodžemiuose per metus biogeninio azoto sujungiama ir vèliau išvežama $\sim 14000 \mathrm{~kg} \mathrm{ha}^{-1}$, o išplaunama su paviršiniu nuotèkiu ir t. t. tik $400 \mathrm{~kg} \mathrm{ha}^{-1}$. Minètuose drègnų atogražų miškuose šie skaičiai per metus atitinkamai yra $25000 \mathrm{~kg} \mathrm{ha}^{-1}$ ir $900 \mathrm{~kg} \mathrm{ha}^{-1}$ (Bridges 1998).

Sudejus visų gylių duomenis ir apibendrinus rezultatus, nustatyta, kad bendrosios anglies kiekis didžiausias yra miško dirvožemyje - 1,520\%; kiek mažesnis - $1,223 \%$ ariamame dirvožemyje; pievos dirvožemyje mažiausias - $0,419 \%$. Lyginant tyrimo metu gautus duomenis pagal literatūrinę apžvalgą, daroma prielaida, kad ariamame dirvožemyje auginant tam tikras kultūras bendrosios anglies kiekis galètų būti didesnis negu daugiamečių augalų dirvožemyje. Tokie tyrimai buvo atlikti JAV: nustatyta, kad anglies kiekis dirvožemyje sumažèjo dèl intensyvesnio daugiamečių augalų kvėpavimo, palyginti su dirvos augalais (Žemès dirbimo... 2010). 


\subsection{Bendrosios anglies kiekio natūrinių tyrimų Užpalių, Paluknio ir Pailiepio vietovių dirvožemiuose duomenys bei analizè}

Atliktų tyrimų duomenimis, bendrosios anglies kiekis pievos dirvožemyje nesuardytos struktūros mèginiuose iš ploto $G$ kito nuo $1,392 \%$ iki $3,585 \%$ (2.23 pav.). Nesuardytos struktūros èminiai buvo imami metaliniu žiedu, o sudètiniai ėminiai - iš visų vietų tam tikro gylio. Sudètinių èminių rezultatai atspindi geresni bendrosios anglies kiekio pasiskirstymą pagal gyli.

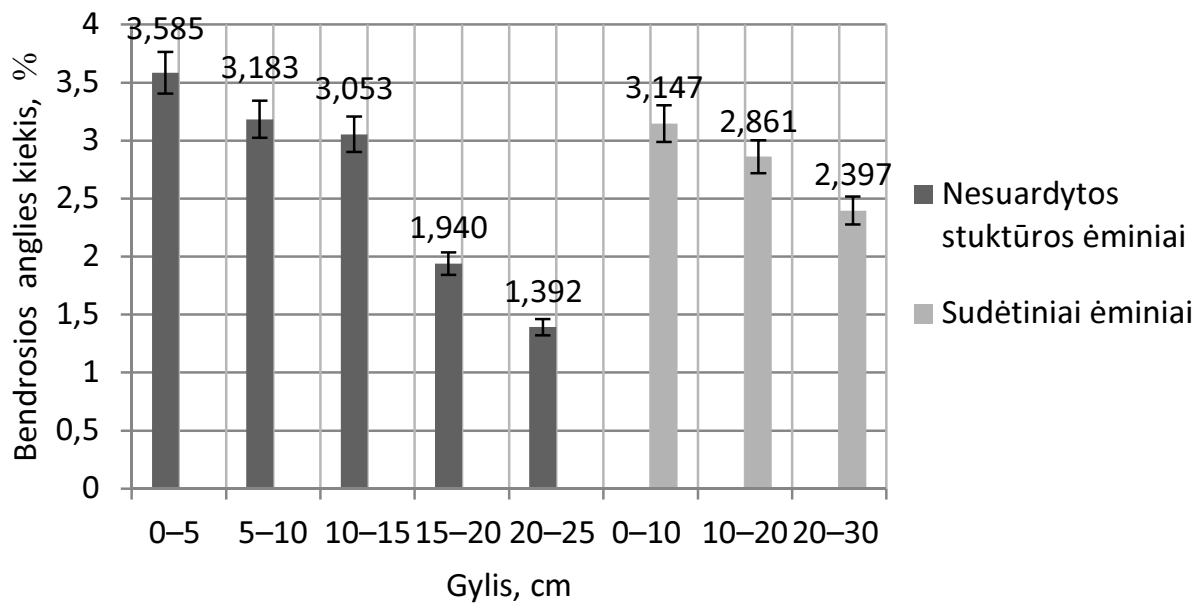

2.23 pav. Užpalių pievos tyrimo vietos $\mathrm{G}$ bendrosios anglies kiekis

Fig. 2.23. Soil total carbon quantity of Užpaliai meadow

$\mathrm{G}$ investigation site

Iš atliktų tyrimų matyti bendrosios anglies kiekio mažejimo tendencija, didejjant gyliui. Didžiausias bendrosios anglies kiekis nustatytas viršutiniame dirvožemio sluoksnyje - 3,585\%. 20-25 cm gylyje jis buvo sumažèjęs 2,6 karto. Sudètinių mėginių bendrosios anglies kiekis dirvožemyje kito nuo 2,397\% iki $3,147 \%$. Palyginti su nesuardytos struktūros dirvožemio mėginių duomenimis, rezultatas skiriasi: 1,1 karto mažiau ties paviršiumi; 1,8 karto daugiau $20-30 \mathrm{~cm}$ gylyje. 


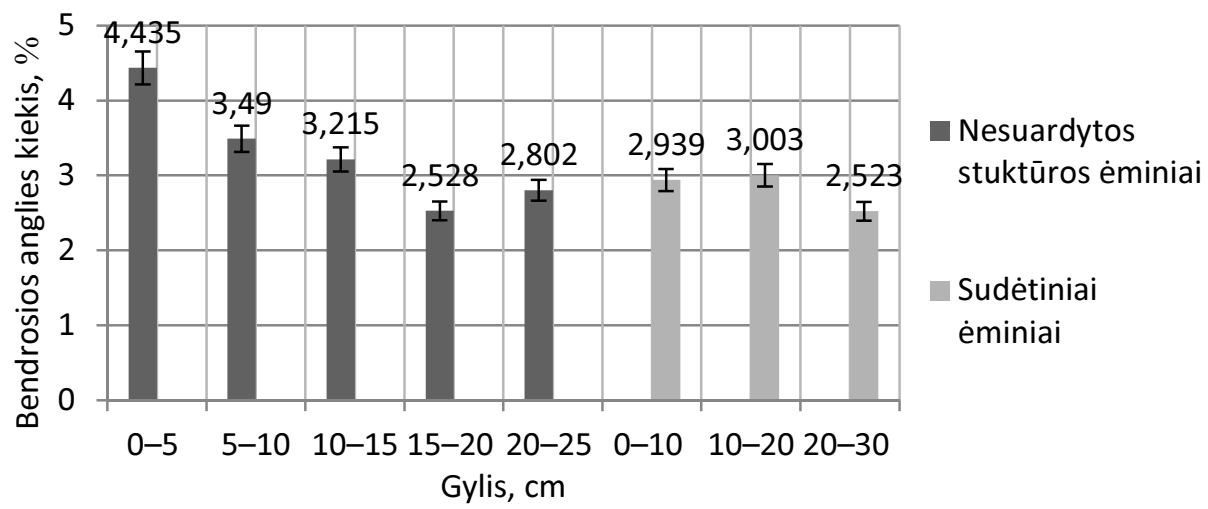

2.24 pav. Užpalių pievos tyrimo vietos GA bendrosios anglies kiekis

Fig. 2.24. Soil total carbon quantity of Užpaliai meadow

GA investigation site

Pievos tyrimo vietoje GA bendrosios anglies kiekis nesuardytos struktūros èminiuose mažèjo nuo 4,435\% paviršiuje iki 2,528\% $15-20 \mathrm{~cm}$ gylyje. (2.24 pav.). Palyginti su sudètinio mèginio tyrimais, bendrosios anglies kiekis ties paviršiumi buvo mažesnis 1,4 karto. $20-30 \mathrm{~cm}$ gylyje skirtumas tarp sudetinio ir nesuardytos struktūros mėginio buvo labai mažas. Tendencingas bendrosios anglies kiekio mažejjimas sudètiniuose èminiuose pievos plote GA nèra ryškus.

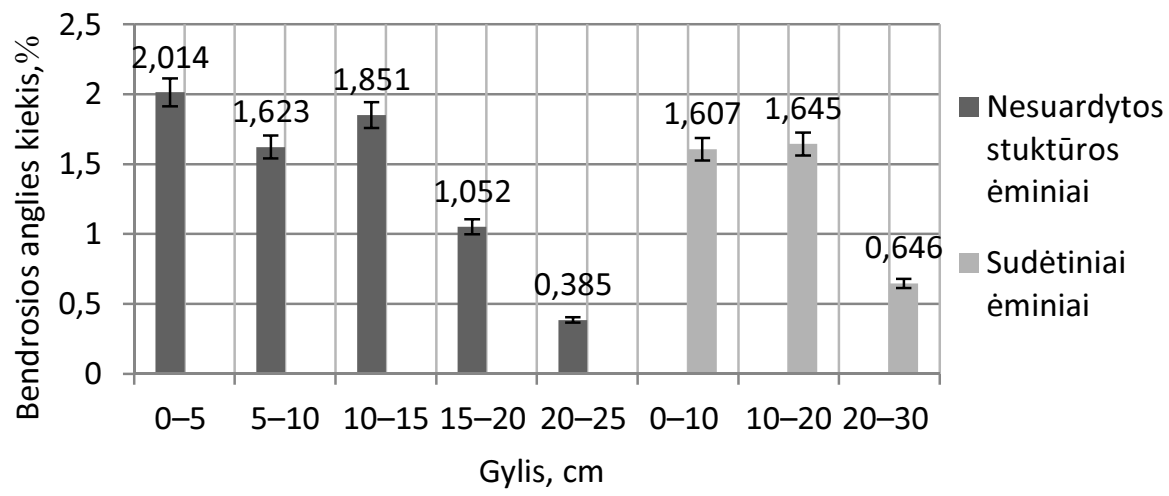

2.25 pav. Užpaliu pievos tyrimo vietos GB bendrosios anglies kiekis

Fig. 2.25. Soil total carbon quantity of Užpaliai meadow

GB investigation site 
Bendrosios anglies kiekis tyrimo vietoje GB, didejant gyliui, kito nuo $2,014 \%$ iki $0,385 \%$. Maksimalus kiekis nustatytas $10-20 \mathrm{~cm}$ gylyje tiek sudètiniuose, tiek nesuardytos struktūros dirvožemio èminiuose. Skirtumas tarp jų neviršija 1,04 karto (2.25 pav.).

Pievos dirvožemio tyrimo plotuose GA bendrosios anglies kiekis nesuardytos struktūros èminiuose kito nuo 1,39\% iki 4,43\%; sudètiniuose èminiuose nuo $2,4 \%$ iki $3,1 \%$. Pievos dirvožemio tyrimo ploto GB bendrosios anglies kiekis nesuardytos struktūros eminiuose buvo mažesnis ir kito nuo $0,38 \%$ iki $2 \%$.

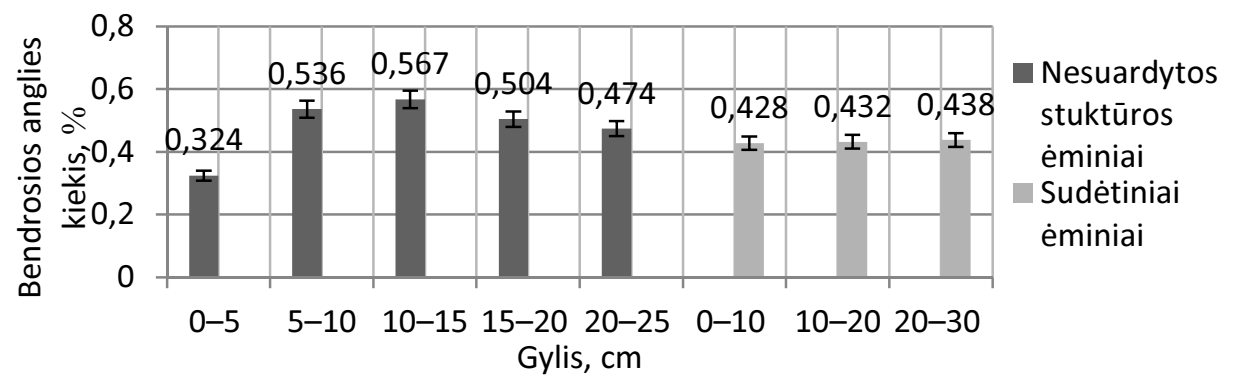

2.26 pav. Paliepio miško tyrimo vietos $\mathrm{R}$ bendrosios anglies kiekis

Fig. 2.26. Soil total carbon quantity of Pailiepis forest $\mathrm{R}$ investigation site

Miško dirvožemio tyrimo vietoje $\mathrm{R}$ maksimalus bendrosios anglies kiekis buvo 5-20 cm gylyje: nuo 0,504\% iki 0,567\% (2.26 pav.). Mažesniame ir didesniame gyliuose jis buvo gerokai mažesnis. Minimalus kiekis $(0,324 \%)$ nustatytas 0-5 cm gylyje. Sudetinių èminių mèginiuose bendrosios anglies kiekis mažai priklauso nuo gylio $(0,428-0,438 \%)$.

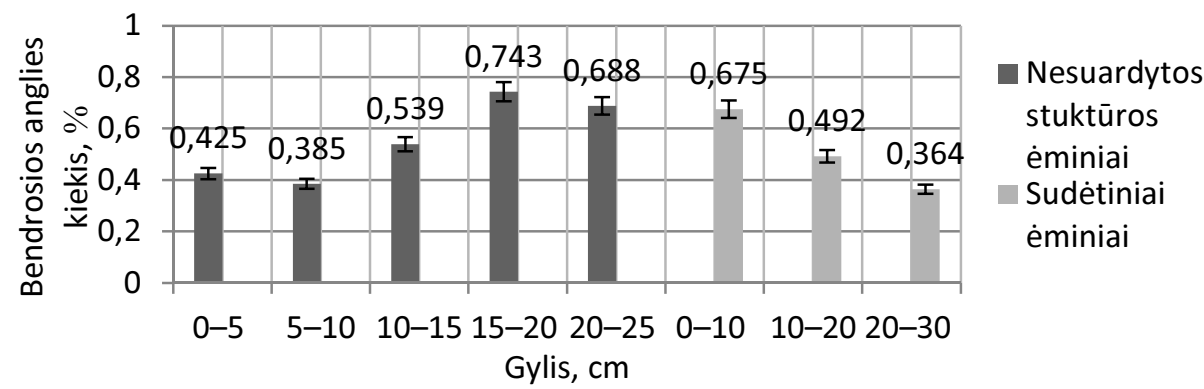

2.27 pav. Paliepio miško tyrimo vietos RB bendrosios anglies kiekis Fig. 2.27. Soil total carbon quantity of Pailiepis forest RB investigation site 
Tyrimo vietos RB nesuardytos struktūros èminių mėginiuose bendrosios anglies kiekis svyruoja tarp $0,385 \%$ ir $0,743 \%$, o mažiausias $(0,385 \%)$ yra $10-15$ $\mathrm{cm}$ gylyje. Sudètinių èminių mèginiuose didžiausias bendrosios anglies kiekis $(0,675 \%)$ nustatytas $0-10 \mathrm{~cm}$ gylyje, minimalus $(0,364 \%)$ nustatytas $20-30 \mathrm{~cm}$ gylyje (2.27 pav.).

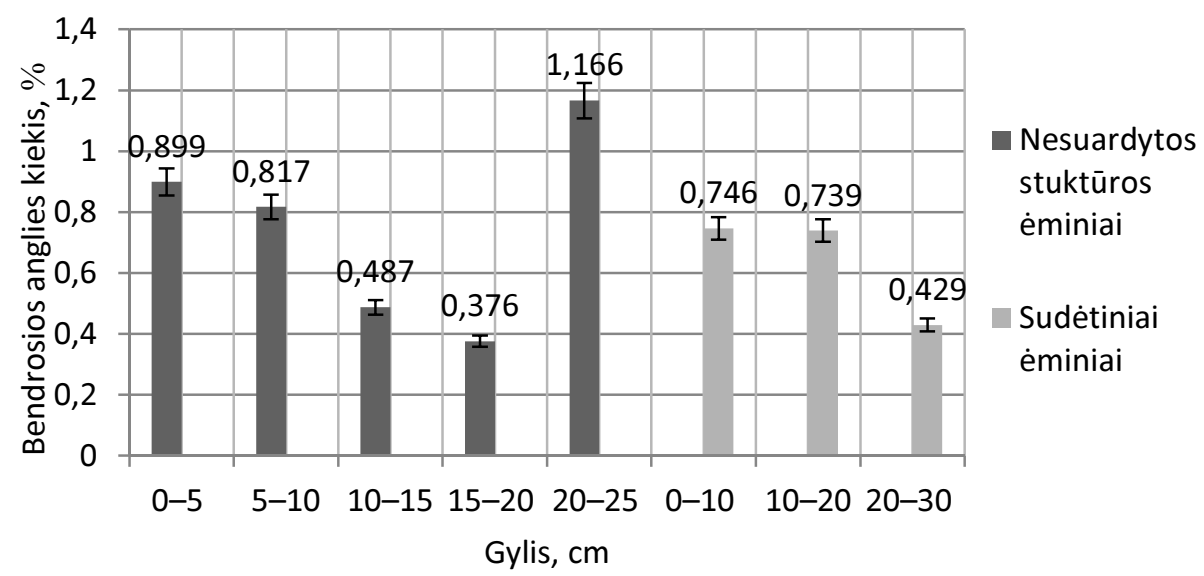

2.28 pav. Paliepio miško RA tyrimo vietos bendrosios anglies kiekis

Fig. 2.28. Soil total carbon quantity of Pailiepis forest RA investigation site

Didžiausias svyravimas, analizuojant miško dirvožemi, nustatytas tyrimo vietoje RA, nors bendra jo tendencija nesikeičia: minimali anglies koncentracija fiksuojama $10-20 \mathrm{~cm}$ gylyje. Neaiški priežastis, kodèl didelis koncentracijos skirtumas nustatytas nesuardytos dirvožemio struktūros ir sudètiniame ėminiuose iš $20-30 \mathrm{~cm}$ gylio: atitinkamai $1,166 \%$ ir $0,429 \%$ (2.28 pav.).

Ariamame dirvožemyje, kurio èminiai imti Paluknyje nustatyta, kad bendrosios anglies kiekis nesuardytos struktūros èminiuose iki $10 \mathrm{~cm}$ gylio vidutinè reikšmè buvo $1,59 \%$ (2.29 pav). Nuo $10 \mathrm{~cm}$ gylio bendrosios anglies kiekis ariamajame dirvožemyje ženkliai sumažèjo. Vidutinis bendrosios anglies kiekis $10-25 \mathrm{~cm}$ gylyje siekè 1,16\%. Sudètiniuose èminiuose bendrosios anglies kiekis kito tolygiai mažejant. $0-10 \mathrm{~cm}$ gylyje bendrosios anglies kiekis buvo 1,1 karto didesnis nei nesuardytos struktūros èminiuose. Tuo tarpu $10-20 \mathrm{~cm}$ ir $20-30 \mathrm{~cm}$ gylyje skirtumas tarp èminių siekè 1,3 karto.

Ariamo dirvožemio BA tyrimo vietos bendrosios anglies kiekis nesuardytos struktūros èminiuose kito tolygiai mažèjant (2.30 pav.). Vidutinè viso tyrinèto profilio nesuartytos struktūros èminių bendrosios anglies kiekis lygus $1,13 \%$. 
Tuo tarpu sudètiniuose èminiuose bendrosios anglies kiekis profilyje buvo $1,51 \%$. Skirtumas tarp analizuotų profilių siekè 1,3\%.

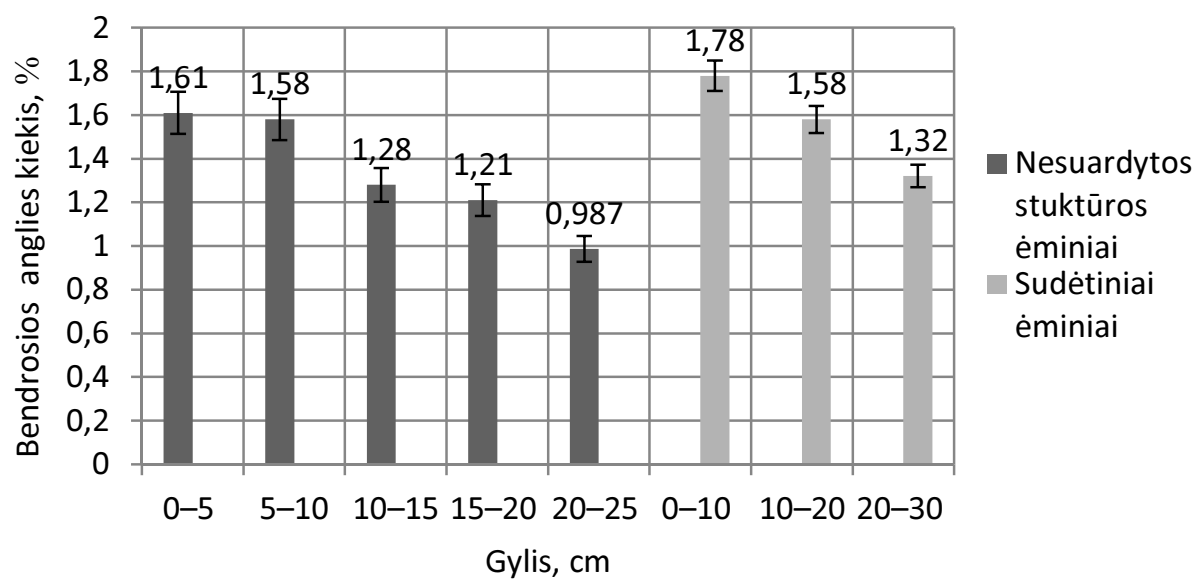

2.29 pav. Paluknio arimo B tyrimo vietos bendrosios anglies kiekis

Fig. 2.29. Soil total carbon quantity of Paluknis arable soil $\mathrm{B}$ investigation site

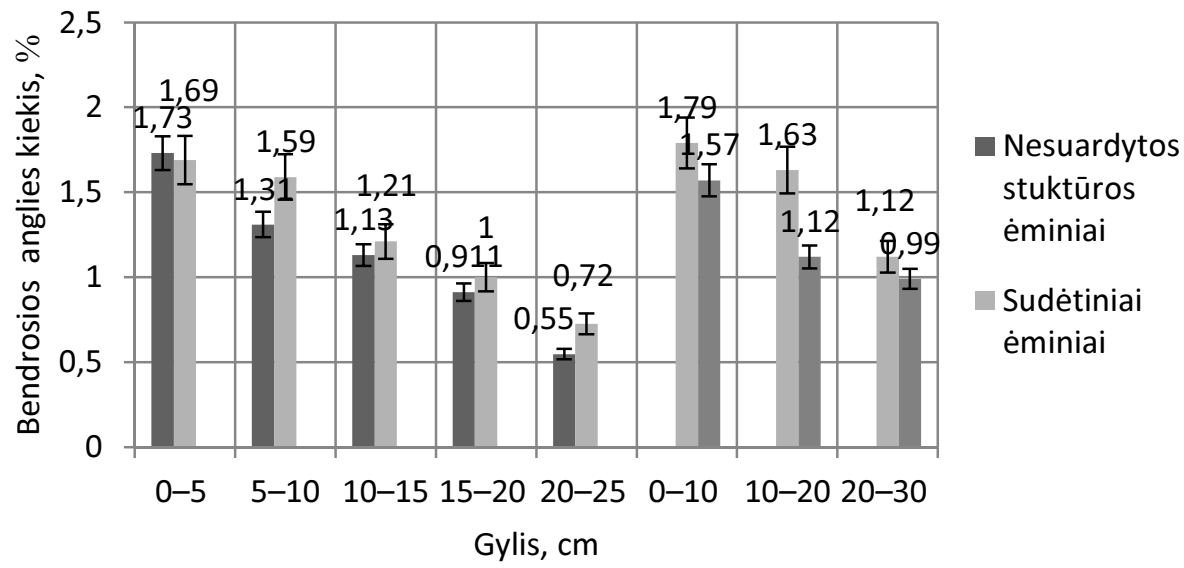

2.30 pav. Paluknio arimo BA ir BB tyrimo vietos bendrosios anglies kiekis

Fig. 2.30. Soil total carbon quantity of Paluknis arable soil BA and BB investigation site Single carbon 
Vidutinis bendrosios anglies kiekis BB tyrimo vietoje nesuardytos struktūros èminiuose siekè $1,24 \%$, o sudètiniuose èminiuose - 1,23\% (2.30 pav.). Iš atliktų tyrimų nustatyta, kad bendrosios anglies kiekis nesuardytos struktūros ariamo dirvožemio èminiuose buvo mažesnis nei sudètiniuose ėminiuose.

Bendrosios anglies kiekis miško dirvožemyje buvo daug mažesnis negu pievos. Dirvožemio ėminiai buvo paimti pušyne, o paviršinès augalijos pušynuose būna mažai, daugiausia ten auga nereiklūs drègmès atžvilgiu augalai. Miško dirvožemio èminiuose nuo $15 \mathrm{~cm}$ gylio prasideda smèlio sluoksnis. Iš miško dirvožemio profilio duomenu, nustatyta, kad bendrosios anglies kiekis nesuardytos struktūros èminiuose kito nuo 2,4\% iki 3,74\%; sudètiniuose - nuo $1,3 \%$ iki $1,9 \%$. Pievos dirvožemio profilio duomenis, nustatytas bendrosios anglies kiekis kito nuo 6,92\% iki 16,47\%; sudetiniuose èminiuose - nuo 3,9\% iki $8,46 \%$. Palyginti su miško dirvožemiu, pievos bendrosios anglies kiekiai profilyje net iki 4,4 karto mažesni ir nesuardytos struktūros, ir sudètiniuose ėminiuose. Ariamajame dirvožemyje skirtumas tarp nesuardytos struktūros ir sudètinių èminių siekè iki 1,3 karto.

Pasitvirtino bendra anglies pasiskirstymo dirvožemiuose tendencija - koncentracijos mažejjimas, didejjant gyliui. Tačiau ši tendencija ryškesnè pievos dirvožemio tyrimui naudojant nesuardytos struktūros èminius (pasiskirstymo koeficientas $\mathrm{Kp}=2,2)$, palyginti su sudètiniais $(\mathrm{Kp}=1,3)$; miško dirvožemyje atvirkščiai (atitinkami pasiskirstymo koeficientai 1,3 ir 2,6). Tikètina, kad tai priklauso nuo pievos ir miško dirvožemio sudèties skirtingo tolygumo pagal gyli ir horizontaliai.

\subsection{Antrojo skyriaus išvados}

1. Natūriniais tyrimais nustatyta, kad bendrosios anglies kiekiui didelès itakos turi reljefas. Todèl tyrimai atlikti imant èminius įvairiuose reljefo aukščiuose. Miško dirvožemyje maksimalus bendrosios anglies kiekis autonominiame landšafte buvo iki 1,5\%. Superakvaliniame landšafte bendrosios anglies kiekis buvo iki 5\%. Pievos dirvožemyje maksimalūs bendrosios anglies kiekiai autonominiame landšafte siekè iki 1,6\%, o superakvaliniame landšafte - iki 3,8\%.

2. İvertinus Neries regioninio parko metinius vidutinius bendrosios anglies kiekius miško dirvožemyje rasta iki 2,43\%, pievos dirvožemyje bendrosios anglies kiekis siekè iki 1,9\%, o ariamajame dirvožemyje bendrosios anglies nustatyta iki $1,7 \%$.

3. Visais analizuojamais laikotarpiais ariamo dirvožemio bendrosios anglies kiekis buvo mažiausias. Palyginus su kitais analizuotais dirvožemiais nustatyta, kad bendrosios anglies kiekis buvo mažiausias lyginant su kitų dirvožemių auto- 
nominiais landšaftais. Kovo mėnesi vidutinès ariamo dirvožemio bendrosios anglies kiekio reikšmès buvo mažiausios už miško dirvožemio bendrosios anglies kieki iki 1,5 karto, o už pievos dirvožemio iki 1,2 karto. Birželio mènesi bendrosios anglies kiekiai ariamame dirvožemyje nežymiai didesni, tačiau jie buvo mažesni 1,2 karto nei miške ir pievoje. Rugpjūčio mènesi bendrosios anglies kiekis ariamame dirvožemyje buvo mažiausias. Iki 1,1 karto mažesnis nei miško dirvožemyje ir 1,2 karto mažesnis nei pievos dirvožemyje.

4. Nustačius dirvožemyje esančios bendrosios anglies kiekius gauta, kad dirvožemyje gyliuose iki $30 \mathrm{~cm}$ gylio kovo mènesị: miško dirvožemyje buvo $5,79 \%$, ariamame dirvožemyje $-4,33 \%$, pievos dirvožemyje $-4,33 \%$, o užliejamos pievos dirvožemyje $-3,89 \%$. Birželio mènesį bendrosios anglies kiekiai gauti: miško dirvožemyje $-8,79 \%$, ariamame dirvožemyje $-5,58 \%$, pievos dirvožemyje $-4,44 \%$, o užliejamos pievos dirvožemyje - 7,39\%. Rugpjūčio ménesi atliktais tyrimais nustatyta, kad bendrosios anglies kiekis miško dirvožemio gyliuose buvo $-7,31 \%$, ariamo dirvožemio profilyje $-5,55 \%$, pievos dirvožemio gyliuose $-4,82 \%$, o užliejamoje pievoje $-7,1 \%$. Iš atliktų tyrimų galima daryti išvadą, kad bendrosios anglies kiekis didžiausias miško dirvožemyje.

5. Nustatyta, kad dirvožemio profiliuose bendrosios anglies kiekis miško dirvožemyje, nesuardytos struktūros èminiuose, kito nuo 2,4\% iki 3,74\%, o sudètinių èminių profiliuose gylyje iki $30 \mathrm{~cm}$ nuo 1,3\% iki 1,9\%. Pievos dirvožemio profiliuose bendrosios anglies kiekiai kinta nuo $6,92 \%$ iki $16,47 \%$, o sudetiniuose èminiuose nuo 3,9\% iki 8,46\%. Atliktais tyrimais ivertinta, kad nesuardytos struktūros èminiai pateikia detalesnę informaciją apie bendrosios anglies kiekius dirvožemyje. Todèl tolesniuose tyrimuose taikytas nesuardytos struktūros èminių èmimas. 


\section{Dirvožemio bendrosios anglies kiekio, pH ir sunkiuju metalu natūriniai tyrimai}

Dirvožemio pH, pagal iprastą terminą - dirvožemio reakcija (Motuzas J. 2005), pripažinta viena iš svarbiausių dirvožemio savybių, lemiančių cheminiusgeocheminius procesus, nuo kuriu priklauso dirvožemio buferingumas, galiausiai dirvožemio ir visos geosistemos jautrumas cheminiam ir mechaniniam poveikiui. Dirvožemio funkcionavimo kokybe didele dalimi priklauso nuo jame susiformavusios mikroorganizmų bendrijos. Mikroorganizmų ir bendrosios anglies kaupimąsi dirvožemyje be $\mathrm{pH}$ tai pat didele dalimi itakoja sunkieji metalai. Sunkieji metalai, patekę i dirva, stabdo augalui reikalingų maisto medžiagų ịsisavinima, šaknų augima, sukelia jaunų augalų chlorozes, lapų nekrozes, įvairius augalų fiziologijos sutrikimus (Baltrènas P., Pranskevičius M. 2009). 


\subsection{Dirvožemio pH, sunkiuju metalų nustatymo bei èminių paèmimo metodika}

Dirvožemio ėminiai bendrosios anglies kiekiui nustatyti paimti šalia Neries regioninio parko Buivydų gyvenvietès (3.1 pav.). Analizei surinkti dirvožemiai iš skirtingos panaudos dirvožemių. Buvo paimti pievos, ariamo lauko ir miško dirvožemių.

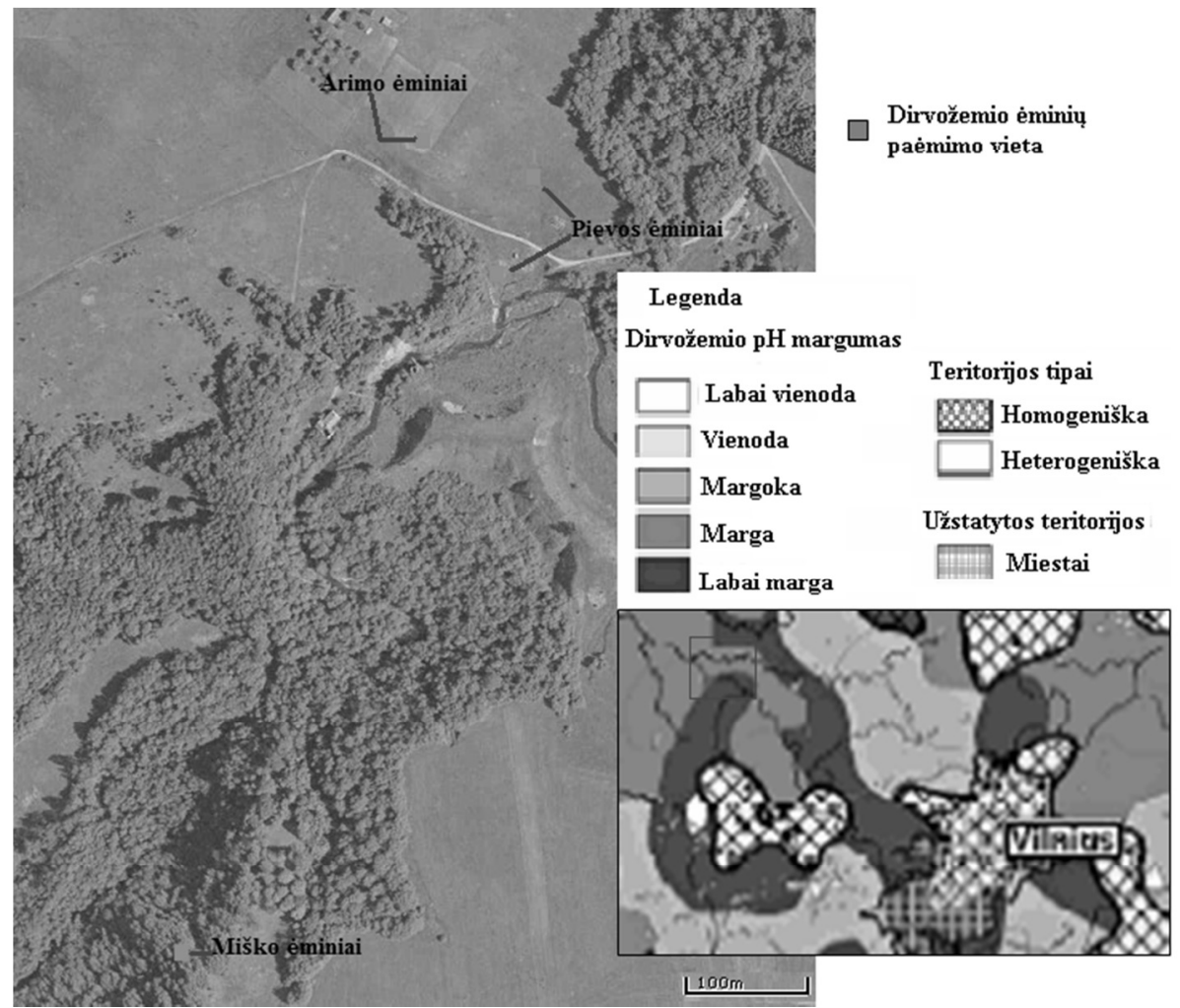

3.1 pav. Dirvožemio pH erdvinès struktūros margumas (Volungevičius 2006) ir èminių paèmimo vieta šalia Buivydų gyvenvietès

Fig. 3.1. Soil pH spatial structure of diversity (Volungevicius 2006) and sampling location near the village Buivydai

Pievos dirvožemio èminiai paimti dviejose vietose išnagrinèti bendrosios anglies kiekius, esant reljefo itakai. Pirmoji tyrimo vieta parinkta autonominiame landšafte (LKS kordinatès 560633; 6077199), o antroji tyrimo vieta parinka superakvaliniame landšafte (LKS koordinatès 560537; 6077097). Ariamo dirvo- 
žemi èminiai paimti iš lauko, kuriame buvo augintos bulvès (LKS koordinatės 560579; 6077245). Miško èminiai paimti iš Karmazinų teritorijos (LKS koordinatès 560350; 6076563).

Dirvožemio pH nustatymo metodika parengta pagal ISO standartą ISO 10390:2005(E). Nustatymo metodas pagrịstas naudojant stiklini elektroda, esant distiliuoto vandens ir mèginio santykiui $5: 1,1 \mathrm{~mol} / 1$ kalio chlorido $(\mathrm{pH}$ kalio chloride $\mathrm{KCl}$ ) arba $0,01 \mathrm{~mol} / 1$ kalcio chlorido tirpale ( $\mathrm{pH}$ kalcio chloride $\mathrm{CaCl}_{2}$ ). Analizei naudojama $2 \mathrm{~mm}$ dirvožemio frakcija. Ėmini prieš analizę džiovinti nedidesnèje nei $40{ }^{\circ} \mathrm{C}$. Mèginiai ruošiami pH analizei laikantis ISO 11464 standarto. Imti $5 \mathrm{ml}$ paruošto dirvožemio ir supilti į konusinę kolbutę. Mègini užpilti $25 \mathrm{ml}$ kalio chlorido arba kalcio chlorido tirpalu. Mègini maišyti $10 \pm 60 \mathrm{~min}$, naudojat laboratorini kratytuvą.

Matavimas atliekamas, esant $2 \pm 20{ }^{\circ} \mathrm{C}$ temperatūrai. $\mathrm{pH}$ reikšmè pateikiama dviejų ženklų po kablelio tikslumu $(\mathrm{pH}=0,02)$.

Sunkiujų metalų bendro kiekio dirvožemyje mėginio paruošimas atominès absorbcijos spektrometrijos (AAS) metodui deginant „Karališkajame vandenyje" $10 \mathrm{~g}$ kieto mèginio džiovinama $105^{\circ} \mathrm{C}$ temperatūroje 2 val. Išdžiovintas mėginys sijojamas per sietus su $1 \mathrm{~mm}$ skersmens akutèmis. $5 \mathrm{~g}$ išdžiovinto mèginio vèl džiovinama $105{ }^{\circ} \mathrm{C} 30 \mathrm{~min}$. Ataušinama eksikatoriuje, pasveriama $0,0001 \mathrm{~g}$ tikslumu 1-1,5 g. Atsvertas mèginys supilamas i plastikini indeli. Sudrèkinamas 0,5$1,0 \mathrm{ml}$ dejonizuoto vandens ir maža srovele pilamos rūgštys: $21 \mathrm{ml}$ konc. $\mathrm{HC} 1,7$ $\mathrm{ml} \mathrm{konc.} \mathrm{HNO}_{3}$.

Po mineralizavimo indelis su mèginiu atvèsinamas iki $50-70{ }^{\circ} \mathrm{C}$. Tada tirpalas iš indelio filtruojamas per stiklo filtrą i $50 \mathrm{ml}$ kolbutę. Indelis maža srovele praplaunamas $5 \mathrm{ml}$ praskiesta $1: 1 \mathrm{HNCh}$, o po to $-5 \mathrm{ml}$ dejonizuoto vandens. Šie praplovimo skysčiai filtruojami per stiklo filtra. Nufiltravus iki žymès kolbutèje skiedžiama su dejonizuotu vandeniu. Po to tyrinejjamos metalų koncentracijos spektrometru Buck Scientific 210 VGP su oro - acetileno liepsna. Jeigu mėginys labai užterštas organinèmis medžiagomis, tuomet atsveriame 10-20 g méginio i porcelianinius tiglius ir mufelyje deginama prie $450{ }^{\circ} \mathrm{C} 12$ val. Po to $1,0-1,5 \mathrm{~g}$ dirvožemio mineralizuojama mineralizatoriuje su ,karališka degtine“. Metodas remiasi elemento koncentracijos matavimais mėginyje naudojant liepsnos atominę absorbcinę spektrometriją. Nustatymo salygos pateiktos 3.2 lenteleje. Sunkiujuc metalų nustatymui naudoti Atominis absorbcinis spektrometras „Buck Scientific" 210 VGP ir Mikrobanginis mineralizatorius „Milestone Ethos“.

Analizuojamų sunkiujų metalų diferenciacija landšaftinèje pievos katenoje gana aiškiai pasireiškia tiriant jų lateraliosios diferenciacijos koeficientus, kurie apskaičiuojami pagal formulę:

$$
\mathrm{K}_{\mathrm{ld}}^{\mathrm{i}}=\mathrm{C}_{\mathrm{sa}}^{\mathrm{i}} / \mathrm{C}_{\text {te }}^{\mathrm{i}},
$$


čia $\mathrm{K}_{\mathrm{ld}}^{\mathrm{i}}$ - lateraliosios diferenciacijos elemento $i$ koeficientas; $\mathrm{C}_{\text {sa }}^{\mathrm{i}}-$ cheminio elemento $i$ koncentracija superakvalinio landšafto dirvožemyje (atitinkamame gylyje), $\mathrm{mg} / \mathrm{kg} ; \mathrm{C}_{\mathrm{te}}^{\mathrm{i}}-$ cheminio elemento $i$ koncentracija horizontaliame landšafto dirvožemyje (tame pat gylyje), $\mathrm{mg} / \mathrm{kg}$.

Cheminių elementų elgesị vertikaliame dirvožemių profilyje galima apibūdinti jų radialios diferenciacijos koeficientais, surandamais pagal formulę:

$$
\mathrm{K}_{\mathrm{rd}}^{\mathrm{i}}=\mathrm{C}_{\mathrm{j}}^{\mathrm{i}} / \mathrm{C}_{\mathrm{c}}^{\mathrm{i}} \text {, }
$$

čia $\mathrm{K}_{\mathrm{rd}}^{\mathrm{i}}$ - radialios diferenciacijos elemento $i$ koeficientas atitinkamame elementariame landšafte; $\mathrm{C}_{\mathrm{j}}^{\mathrm{i}}$ - cheminio elemento $i$ koncentracija dirvožemio horizonte $j, \mathrm{mg} / \mathrm{kg} ; \mathrm{C}_{\mathrm{c}}^{\mathrm{i}}-$ cheminio elemento $i$ koncentracija dirvodarinèse uolienose, $\mathrm{mg} / \mathrm{kg}$.

\subsection{Dirvožemio bendrosios anglies kiekio, pH ir sunkiujų metalų natūriniai tyrimai Neries regioniniame parke duomenys ir analizè}

Atlikinejjant dirvožemio bendrosios anglies ir $\mathrm{pH}$ tyrimus nustatyta, kad pievos dirvožemio èminiuose bendrosios anglies kiekis pasiskirstė tolygiai mažejančia tendencija didejjant gyliui sudètiniuose èminiuose. Sudetiniai èminiai imami iki $1 \mathrm{~kg}$ dirvožemio masès. Šie èminiai imti iš kiekvienos èminių paèmimo vietos ir to paties gylio. Paimtas èminiai homogenizuojamas siekiant gauti detalesnius tyrimo duomenis. Giluminiame èminyje paimti èminiai naudojant grąžta. Juo paimami dirvožemio èminiai iki 1 metro gylio. Analizès metu atskleidžiamas dirvožemio bendrosios anglies pasiskirstymas pagal gyli.

Žvelgiant i $0-10 \mathrm{~cm}$ gyli nustatyta, kad tiek sudetiniame tiek ir giluminio éminio 0-20 cm tyrimo duomenys kinta. Tačiau, skirtumas buvo tik $0,196 \%$. 10-20 cm gylyje bendrosios anglies kiekis taip pat atitinka sudetinio éminio bendrosios anglies kiekis su nedideliu skirtumu. Didžiausias bendrosios anglies kiekis nustatytas $60-80 \mathrm{~cm}$ gylyje ir siekè $-4,416 \%$. Palyginus su paviršiniosluoksnio tyrimo duomenimis matyti, kad bendrosios anglies kiekis $60-80 \mathrm{~cm}$ yra didesnis $0,348 \%$. Tolesni tyrimai atskleidè staigų bendrosios anglies kiekio sumažejimą $80-100 \mathrm{~cm}$ gylyje. Atlikus tyrimus padaryta išvada, kad bendrosios anglies kiekis šiame dirvožemyje pasiskirstęs iki $80 \mathrm{~cm}$ gylio su tendencija kauptis (3.2 pav.).

$\mathrm{pH}$ tyrimo duomenis nustatyta, kad sudètiniuose èminiuose iki $30 \mathrm{~cm}$ gylio $\mathrm{pH}$ reikšmè kinta ribose nuo 7,4 iki 7,51. Nežymus padidejimas nustatytas 10 $20 \mathrm{~cm}$ gylyje. Giluminiame èminyjenustatyta, kad $\mathrm{pH}$ reikšmé didejant gyliui 
palaipsniui didejo iki $60 \mathrm{~cm}$ gylio. Nuo $60 \mathrm{~cm}$ gylio $\mathrm{pH}$ reikšmès kito sąlyginai mažose ribose ir vidutinè vertè siekè 7,3 (3,2 pav.).

Atlikus bendrosios anglies tyrimus transeliuvinio landšafto pievoje nustatyta, kad bendrosios anglies kiekiai giluminiuose èminiuose kito tolygiai mažèjant. Sudètiniuose ėminiuose šie kiekiai kito taipogi mažejimo kryptimi. Tačiau, palyginus abi ejųeminių bendrosios anglies kiekius nustatyta, kad bendrosios anglies kiekis kito mažai iki 1\%. Iš ankstesnių tyrimų nustatyta, kad didžiausis bendrosios anglies kiekiai gaunami superakvalinio landšafto èminiuose. transeliuviniai landšaftai veikiami vejjo ir vandens erozijos netenka dirvožemyje esančios anglies. Dèl to bendrosios anglies tyrimai parodo mažesnius kiekius, kadangi dalis anglies kiekio yra išplaunama.

$\mathrm{pH}$ reikšmès nustatytos antroje pievos tyrimo vietoje gauta, kad sudètiniuose ėminiuose $\mathrm{pH}$ reikšmès nuo $20 \mathrm{~cm}$ gylio palaipsniui didejo, o $0-10 \mathrm{~cm}$ gylyje nustatyta didžiausia reikšmè $-5,57$.
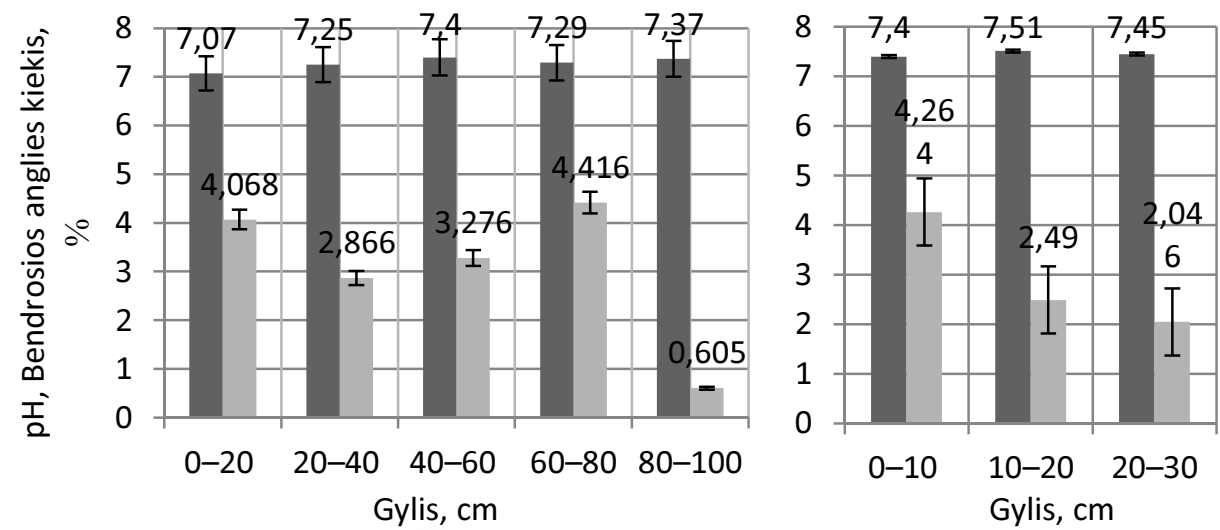

$\mathrm{A}-\mathrm{pH}$ Bendrosios anglies kiekis, \% B

3.2 pav. Dirvožemio $\mathrm{pH}$ ir bendrosios anglies kiekis pirmoje pievos tyrimo vietoje: A - giluminiame èminyje; B - sudetiniame èminyje

Fig. 3.2. Soil $\mathrm{pH}$ and total carbon quantity in first meadow investigation site: A - a abyssal sample B - a composite sample

Miško dirvožemyje bendrosios anglies kiekiai giluminiuose ėminiuose kito muo 2,182 iki 2,282\%, esant $40 \mathrm{~cm}$ gyliui (3.4 pav.). Paviršiniuose sluoksniuose bendrosios anglies kiekis sudetiniuose éminiuose 1,4 karto didesnis nei giluminiuose. Taip pat ir kituose gyliuose bendrosios anglies kiekis sudètiniuose èminiuose buvo didesnis nei giluminiuose. Vertinant landšafto bendrosios anglies kiekius, juos geriausiai atspindejo giluminiai èminiai.

$\mathrm{pH}$ reikšmès miško dirvožemyje taip pat pasiskirstè pagal gyli didejjančia tvarka. Nežymus pH kitimas nustatytas tik iki $60 \mathrm{~cm}$ gylio. Tačiau gilesniuose 
sluoksniuose $\mathrm{pH}$ didejjimas priklauso nuo gylio. Tačiau reikia pastebèti, kad didžiausia nustatyta $\mathrm{pH}$ sudètinio èminio reikšmè atitiko $60 \mathrm{~cm}$ gylyje esančią reikšmę giluminiame ėminyje. Tačiau, bendra tendencija išliko ta pati: didejant gyliui $\mathrm{pH}$ reikšmès didejja, o bendroji anglies mažèja (3.4 pav.).
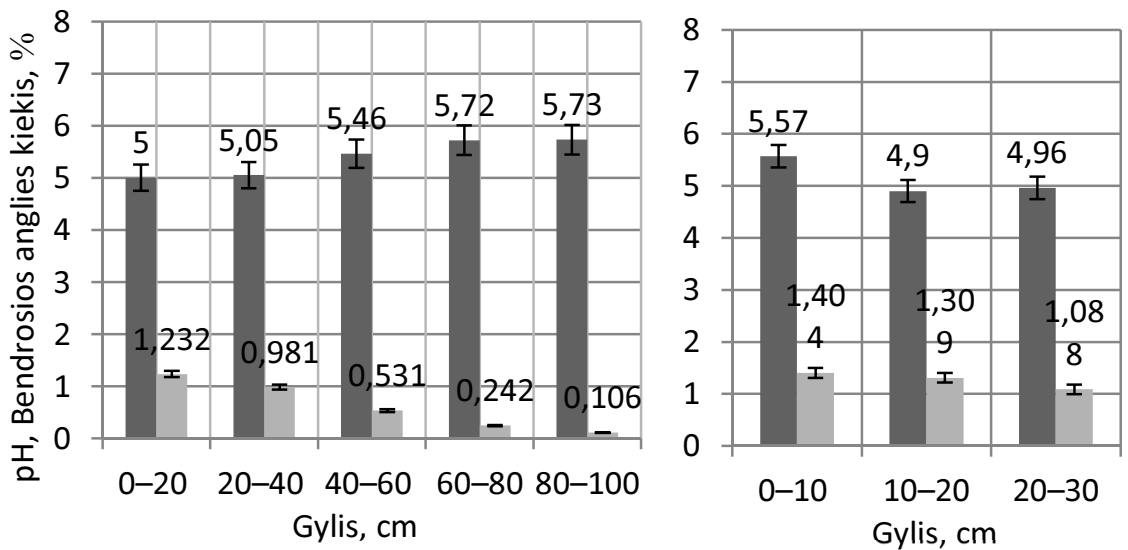

$\mathrm{A}{ }_{\mathrm{pH}}$ Bendrosios anglies kiekis, \% B

3.3 pav. Dirvožemio $\mathrm{pH}$ ir bendrosios anglies kiekis antroje pievos tyrimo vietoje: A - giluminiame èminyje; B - sudetiniame èminyje

Fig. 3.3. Soil $\mathrm{pH}$ and total carbon quantity in second meadow investigation site: A - a abyssal sample B - a composite sample
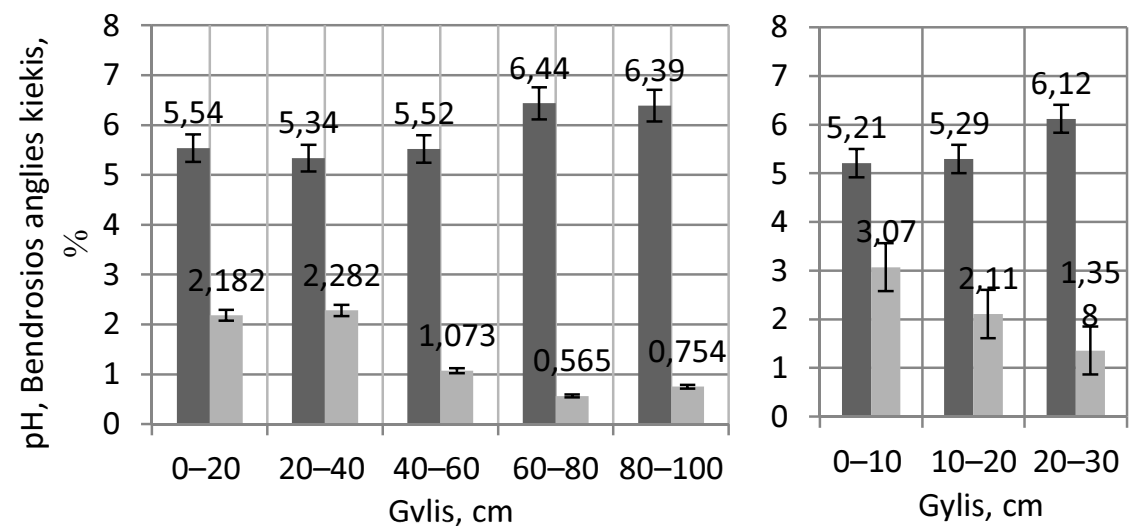

$\mathrm{A}{ }_{\mathrm{pH}} \quad$ Bendrosios anglies kiekis, \% B

3.4 pav. Dirvožemio $\mathrm{pH}$ ir bendrosios anglies kiekis miško dirvožemyje:

A - giluminiame èminyje; B - sudètiniame èminyje

Fig. 3.4. Soil $\mathrm{pH}$ and total carbon quantity in forest soil: $\mathrm{A}-\mathrm{a}$ abyssal sample B - a composite sample 

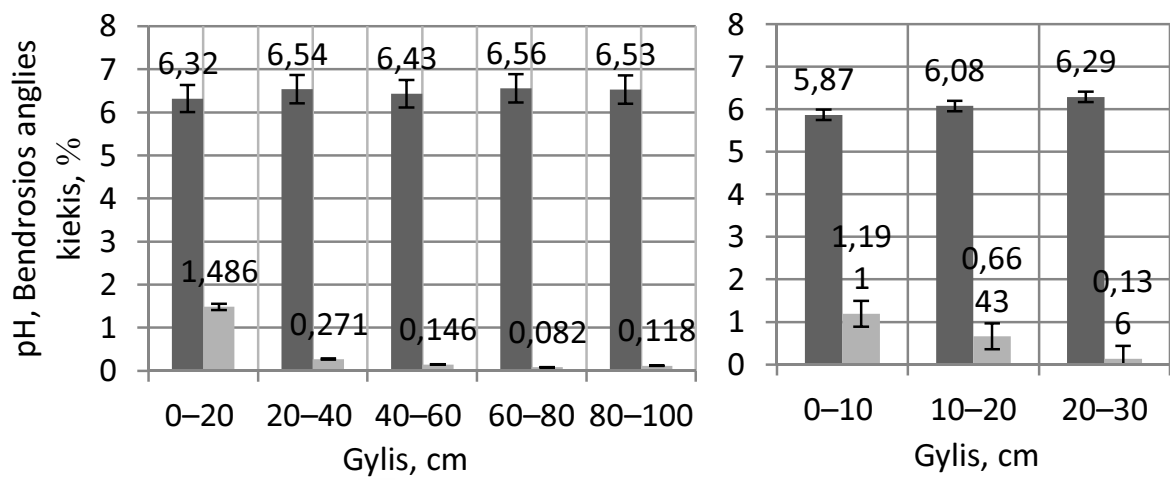

$\mathrm{A} \quad \mathrm{pH} \quad$ Bendrosios anglies kiekis, \% $\mathrm{B}$

3.5 pav. Dirvožemio $\mathrm{pH}$ ir bendrosios anglies kiekis ariamame dirvožemyje: A - giluminiame èminyje; $\mathrm{B}$ - sudetiniame ėminyje

Fig. 3.5. Soil $\mathrm{pH}$ and total carbon quantity in arable soil: $\mathrm{A}-\mathrm{a}$ abyssal sample B - a composite sample

Ariamame dirvožemyje bendrosios anglies kiekis nustatytas mažiausias iš visų analizuotų dirvožemių èminių (3.5 pav.). Šiame dirvožemyje anglies kiekis giluminiuose èminiuose paviršiuose sluoksniuose siekè 1,486\%. Gilesniuose sluoksniuose bendruosios anglies kiekiai staigiai sumažejo. Imant dirvožemio èminius nustatyta, kad nuo $30 \mathrm{~cm}$ gylio prasidèjo smèlis. Sudètiniuose èminiuose bendrosios anglies kiekis dirvožemio profilyje sumažejo net iki 8,7 kartų.

Palyginus bendrosios anglies giluminių èminių kiekius su analizuojamais dirvožemiais nustatyta, kad ariamo dirvožemio bendrosios anglies kiekis paviršiniame sluoksnyje mažesnis 2,7 karto nei autonominio landšafto pievos èminyje ir 0,8 karto nei transeliuvinio landšafto pievoje, o miško dirvožemyje 1,5 karto daugiau.

Sunkiujų metalų tyrimai atlikti siekiant ịvertinti dirvožemių užterštumą. Atliekant tyrimus buvo ịvertinti $\mathrm{Zn}, \mathrm{Cu}$ ir Pb sunkieji metalai. Metalų pasirinkimą itakojo ju judrumas dirvožemyje. Sunkieji metalai tokie kaip $\mathrm{Mn}, \mathrm{Zn}, \mathrm{Cu}$ yra judrūs metalai. Šie metalai prie atitinkamų $\mathrm{pH}$ reikšmių gali būti išplaunami iš dirvožemio i gilesnius sluoksnius. Švinas tuo tarpu parinktas kaip mažiausiai judrus metalas.

Miško dirvožemio analizès metu nustatyta, kad didžiausios vario ir cinko koncentracijos buvo kuomet dirvožemio buvo esant $\mathrm{pH}$ 6,39 ir siekè atitinkamai 36,1 ir 98,5 mg/l. Švino koncentracija didžiausia buvo esant pH 5,34-292 mg/l.

Ariamo dirvožemio sunkiųjų metalų pasiskirstymui įtakos turi mechaninis dirvožemio apdirbimas. Šiame dirvožemyje didžiausių koncentracijų maksimumiai judriesiems metalams nustatyti esant $\mathrm{pH}$ reikšmėms: cinkui - 6,43 $(96,5$ 
$\mathrm{mg} / \mathrm{l})$, variui - 6,43 (37,9 mg/l). Didžiausia švino koncentracija nustatyta, esant $\mathrm{pH}$ reikšmei $6,53(17,7 \mathrm{mg} / \mathrm{l})$.

Pievos dirvožemyje didžiausios sunkiujų metalu koncentracijos, esant $\mathrm{pH}$ reikšmèms: cinko $6(67,7 \mathrm{mg} / \mathrm{l})$, variu $6,2(39,7 \mathrm{mg} / \mathrm{l})$. Švino daugiausiai nustatyta tuomet kai pH buvo tarp 6,2 ir 6,6 ir kito nuo 14,6 iki $16,5 \mathrm{mg} / \mathrm{l}$.

Kadangi analizuojamujų sunkiųų metalų koncentracija visuose mėginiuose žymiai mažesnè nustatytų HN-60:2004 ribinių dirvožemyje verčių, apie jų užterštumą metalais kalbèti neverta. Todèl toliau analize lies tiktai metalų pasiskirstymą įvairiuose dirvožemiuose pagal žemènaudos tipa, gyli.

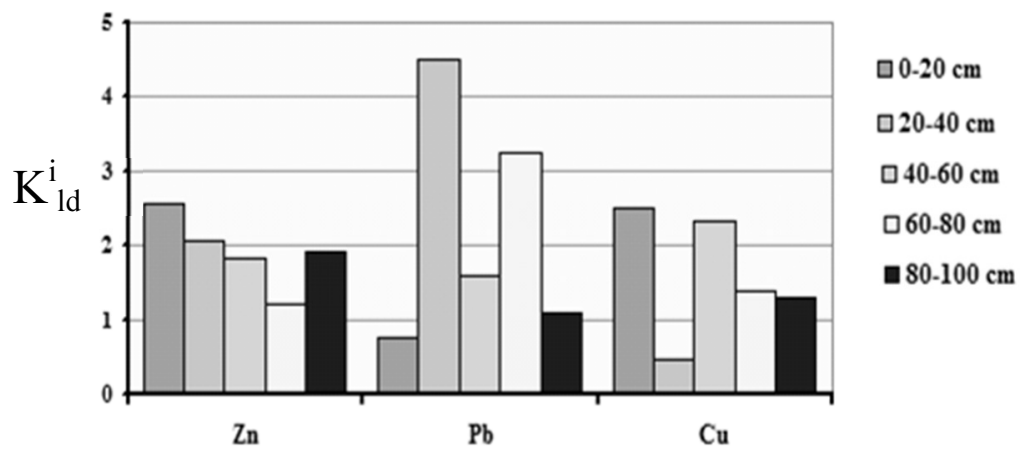

3.6 pav. Lateralioji metalų diferencijacija pievos dirvožemiuose Fig. 3.6. Horizontal havy metal differentiation in grassland soils

Daugiau ar mažiau visų metalų koncentracijos priklausomos nuo atitinkamo žemès ploto paskirties. Taip paviršutiniame puveningame dirvožemio horizonte (gylis $0-20 \mathrm{~cm}$ ) maksimalios cinko ir vario koncentracijos būdingos superakvalinio landšafto pievai, tuo tarpu kaip švino - miško dirvožemiui. Žemutiniame dirvožemio horizonte $(60-80 \mathrm{~cm})$ maksimalia cinko koncentracija išsiskiria miškas, vario - miškas ir dirbamoji žemè, švino - pieva superakvalinio landšafto pozicijoje (3.6 pav.).

Kaip tai atrodo ištirtuose pievos plotuose pateikta (3.1 pav). Daugelyje atvejų $\mathrm{K}_{\text {ld }}^{\mathrm{i}}>1$, t. y. visi trys metalai superakvalinio pievų landšafto dirvožemyje rodo tendenciją kauptis. Nuosekliausiai šis pasireiškia cinko atžvilgiu, kurio $\mathrm{K}_{\mathrm{ld}}$ mažeja nuo 2,56 gylyje $0-20 \mathrm{~cm}$ iki 1,21 gylyje $60-80 \mathrm{~cm}$. Švino ir vario lateraliosios diferenciacijos koeficientai su nedaugeliu sunkiai paaiškinamų išimčių rodo tą pat tendenciją. Ribota analitinè medžiaga kol kas neleidžia argumentuotai paaiškinti šio koeficiento mažesnes kaip 1,0 reikšmes.

Vertikalioji elementų diferenciacija miško dirvožemyje pateikta (3.7 pav). Kaip matosi, ji gana skirtinga: geriau tirpūs ir judrūs rūgštinguose $(\mathrm{pH}=5,3-6,5)$ miško dirvožemiuose cinkas ir varis dirvodariniais procesais daugiausia iššarmi- 
nami, eliminuojami iš dirvodarinių uolienu $\left(\mathrm{K}_{\mathrm{rd}}^{\mathrm{i}}<1\right)$. Ypatingai aktyviai ǐšararminimas vyksta paviršutiniame dirvožemio horizonte ir kiek giliau, pasireiškiant jaurejjimo procesams. Švinas kaip geochemiškai mažiau judrus elementas skirtingai nuo cinko ir vario visuose dirvožemio horizontuose palyginant su dirvodarinèmis uolienomis kaupiasi, ypatingai praturtintame bendrosios anglies ir humuso puveniniame horizonte A1.

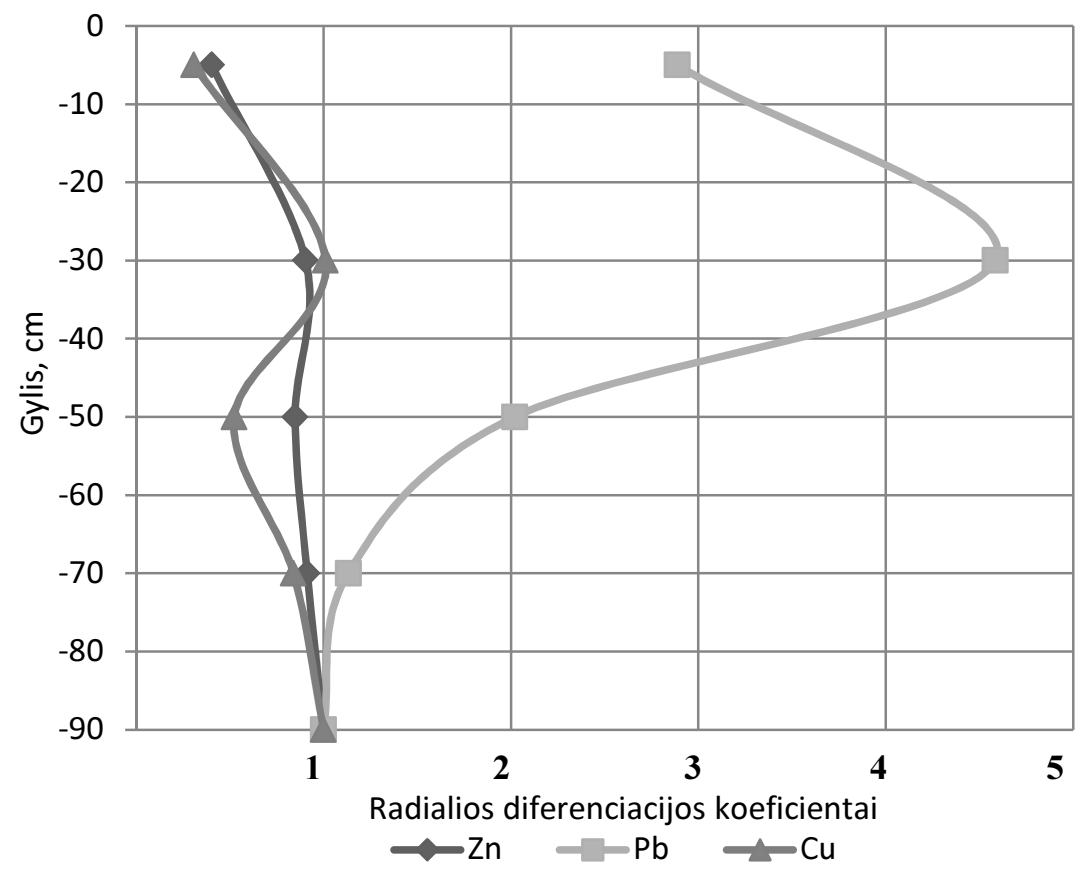

3.7 pav. Sunkiujjų metalų diferencijacija transeliuvinio landšafto pievos dirvožemio profilyje

Fig 3.7. Heavy metals differentiation transelluvial landscape meadow soil profile

Kiek kitaip vertikalioji $\mathrm{Zn}, \mathrm{Pb}$ ir $\mathrm{Cu}$ diferenciacija pasireiškia pievos dirvožemyje transeliuvinio, artimo eliuviniam landšafto pozicijoje (3.8 pav.). Pirma, diferenciacija čia mažiau kontrastinga $\left(\mathrm{K}^{\mathrm{Zn}}\right.$ rd vos viršija 1,6$)$. Antra, skirtingai nuo miško dirvožemio tarp iššarminamų cheminių elementų čia yra ir švinas, minimali koncentracija kurio sutampa su minimaliaja bendros anglies koncentracija jauriniame dirvožemio horizonte A2. Padidejusiomis švino ir vario koncentracijomis žymimas iliuvinis dirvožemio horizontas B. 


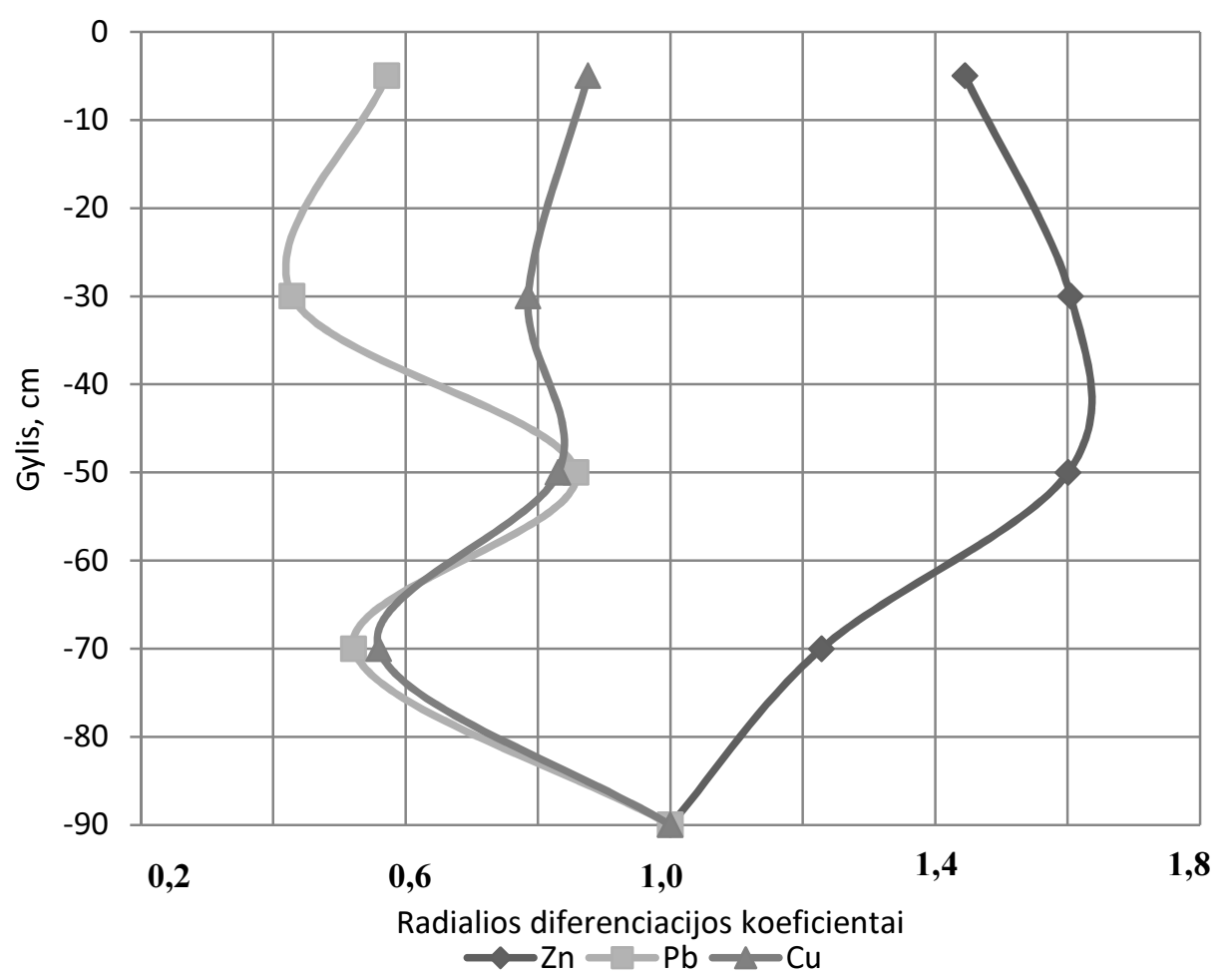

3.8 pav. Sunkiujų metalų diferencijacija miško dirvožemio profilyje

Fig. 3.8. Heavy metals in forest soil profile diferentiation

Superakvaliniai $\mathrm{H}^{+}$- klasès vandens migracijos landšaftai, kaip žinoma, paprastai apibūdinami kaip išplautų iš eliuvinių ir transeliuvinių landšaftų dirvožemių cheminių elementu kaupimosi vieta. Šiam palanki yra bendra susidaranti juose geochemine situacija: sustipreją mechaninis hidrodinaminis ir sorbcinis susijęs su molio mineralu ir humuso kaupimusi geocheminiai barjerai, pastovus paviršutinis ir intradirvožeminis tirpių vandenyje metalų junginių iplaukimas, padidintas dirvožemio storis ir veikiantis jame filtracinis geocheminis barjeras. Taip, paviršutiniuose dirvožemio horizontuose iki gylio $35-40 \mathrm{~cm}$ bendrosios anglies kiekis viršija jos atitinkamą kiekį transeliuvinio pievos landšafto pozicijoje nuo 2,9 iki 3,3 kartų, o iliuviniame horizonte B - net 18,2 kartų. 


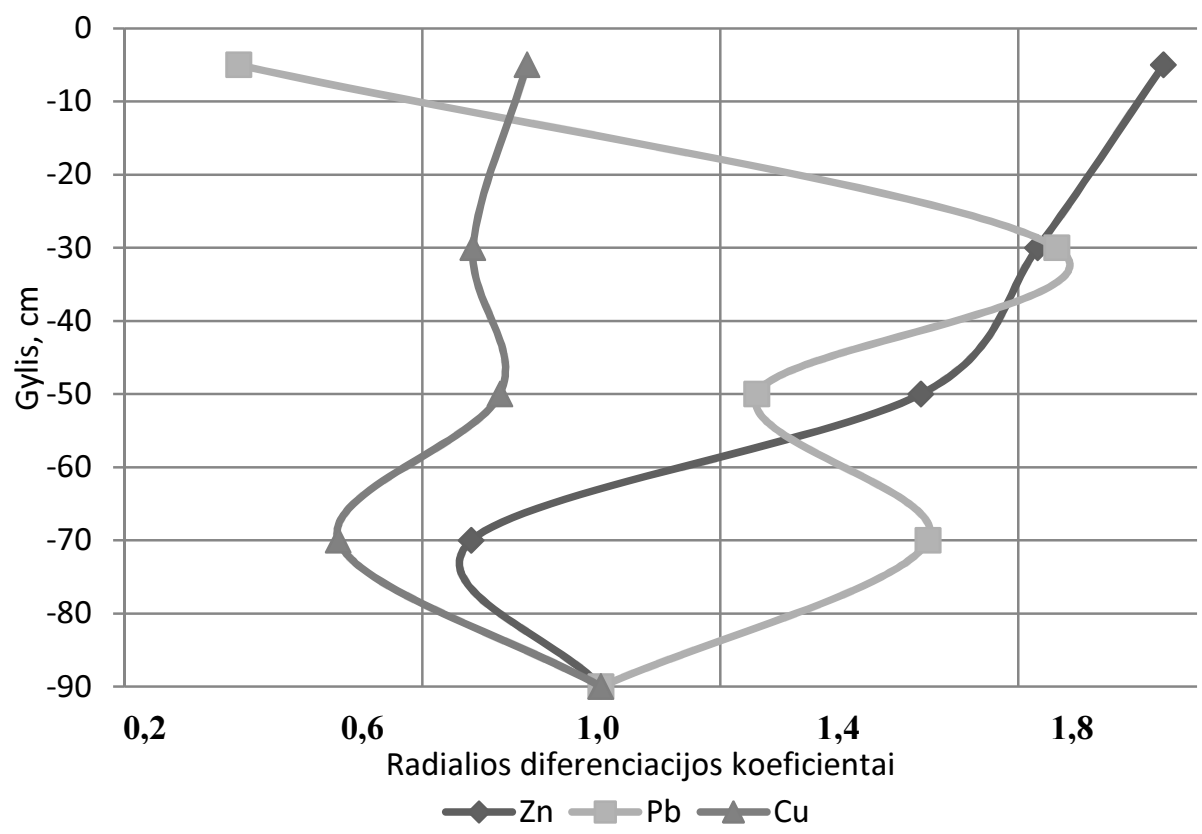

3.9 pav. Sunkiujų metalų diferencijacija superakvalinio pievos dirvožemio profilyje

Fig. 3.9. Heavy metals differentiation superaqual landscape meadow soil profile

Nenuostabu, kad tokiose sąlygose ypač intensyviai kaupiasi ir sorbuojami humusu iš dirvožemio tirpalų metalai. Kaip išplaukia iš 3.9 pav., aktyviau yra kaupiami cinkas ir švinas, ypatingai puveningame dirvožemio horizonte. Tiesa, nevisai aiški priežastis anomaliai mažos švino koncentracijos viršutinejje šio horizonto dalyje. Turbūt kiek tai galima orientuotis apžvelgiamų metalų fulvakompleksų silpnai rūgštingoje $(\mathrm{pH} \approx 5,0)$ terpejje stabilumu. Sulig R. Brukso, tokiose sąlygose jų junginių stabilumas atitinka eilei $\mathrm{Cu}>\mathrm{Pb}>\mathrm{Zn}$. Šis reikštų, kad transeliuvinio landšafto sąlygose organiniuose kompleksuose geriau migruotų $\mathrm{Cu}$ ir $\mathrm{Pb}$ (ir jų mažiau liktų šio dirvožemio sudètyje). Be to, jie skirtingai nuo Zn lengviau iveiktų šarmini superakvalinio landšafto dirvožemio geochemini barjera, ypatingai švinas.

Kaip ir transeliuvinio landšafto atžvilgiu, čia taip pat matosi nevisai aiškios prigimties geochemiškai judresnių $\mathrm{Zn}$ ir $\mathrm{Cu}$ betarpiškai aukščiau dirvodarinès molingos uolienos minimumas, kuris kaip ir ankščiau preliminariai siejamas su artimais sufozijai išplovimo ir padidejusios vandens apykaitos procesais. 


\subsection{Trečiojo skyriaus išvados}

1. Ivertinus giluminius ir sudètinius èminius nustatyta, kad vidutiniai bendrosios anglies kiekiai daugeliu atveju giluminių eminių tyrimuose yra mažesni. Pievos èminiuose skirtumas siekè 2,1 karto traneliuviniame landšafte. Miško dirvožemyje - 1,5 karto, o ariamame dirvožemyje 1,6 karto mažesni.

2. Ariamame dirvožemyje pagal atliktus tyrimus nustatyta, kad dèl dirvožemio apdirbimo buvo sunku ivvertinti geocheminius barjerus, kadangi natūralų gamtini humusingą A horizontą pakeičia AA tipo horizontas iki $26 \mathrm{~cm}$ gylio. Priklausomai nuo arimo pobūdžio suariama ir dalis po $A_{1}$ buvusio eliuvinio $A_{2}$ (E) horizonto. Nustatyta, kad anglies kiekis dèl sorcinių savybių yra labiau susijęs su švino kiekiu. Pagal kitus nustatinejjamus metalus, kurie dirvožemyje yra judresni nei švinas buvo nustatytas filtracinis geocheminis barjeras.

3. Lateralioji metalų diferenciacija pievos landšaftų katenoje transeliuvinis superakvalinis landšaftai pasireiškia jų kaupimusi superakvalinio landšafto dirvožemyje, ypatingai jo paviršiniuose horizontuose, kuriuose reikšmingiausią diferenciacijos koeficientą rodo cinkas $(2,56$ gylyje $0-20 \mathrm{~cm})$. Gilesniuose dirvožemio horizontuose lateralios diferenciacijos koeficiento reikšmès mažeja, daugelyje atvejų vis tiktai nurodydamos i metalų kaupimosi tendenciją.

4. Išanalizavus sunkiujjų metalų migracija miško dirvožemyje nustatytas tendencingas geocheminis barjeras B horizonte, vadinamame iliuviniu. Dèl šio barjero nuo $40 \mathrm{~cm}$ gylio nustatytas sunkiujų metalų ir bendrosios anglies kaupimasis.

5. Kaip kombinuotais geocheminis barjeras (filtracinis+sorbcinis) dirvožemiuose veikia jų iliuvinis (moliuotais) horizontas, pasižymintis humuso ir sunkiujjų metalų akumulialiaciją. 


\section{Anglies dioksido emisiju išsiskyrimo iš Neries regioninio parko dirvožemių natūriniai tyrimai}

Tyrimų tikslas buvo nustatyti anglies dioksido emisijos dydị skirtingos panaudos tipo dirvožemiuose. Gauti duomenys bus naudojami dirvožemio bendrosios anglies ir anglies dioksido emisijų ryši nustatant modeliavimo būdu. Matuojama prietaisu ADC SRS-1000, kurio veikimas pagristas infraraudonujų spindulių absorbcija. Matavimai buvo atlikti rugsèjo ir rugpjūčio mėnesiais. Matavimo metu užfiksuotos anglies emisijos dydžio vertès, aplinkos rodikliai ir prietaisu ivertintas dirvožemio drègnis (Baltrènas P., Pranskevičius M., Lietuvninkas A. 2010).

\subsection{Anglies dioksido emisijos tyrimo metodika}

Anglies dioksido emisijos tyrimai buvo atliekami tose vietose (4.1 pav.), kuriose atlikti bendrosios anglies tyrimai. Šios tyrimo vietos parinktos, norit ivertinti bendrosios anglies ir anglies dioksido emisijų sąsają. 


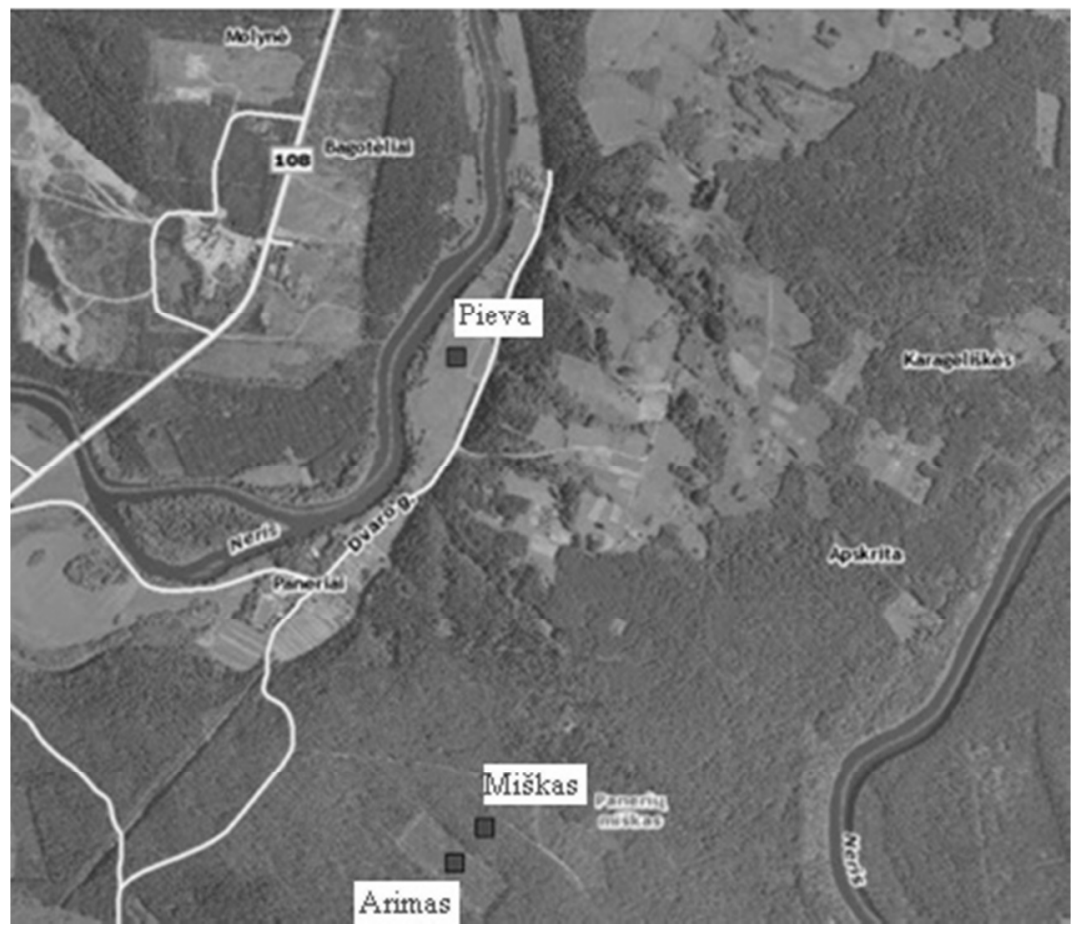

4.1 pav. Neries regioninio parko dirvožemio anglies dioksido emisijų matavimo vietos

Fig. 4.1. Carbon dioxide emissions measurement location in the Regional Park of Neris soils

Anglies dioksido išsiskyrimo iš dirvožemio prietaisą ADC SRS-1000 sudaro kompaktiška programavimo konsolè, dirvožemio kvėpavimo kamera ir metalinis žiedas, prie kurio tvirtinama matavimo kamera. Matuojant metalinis žiedas ismeigiamas į dirvožemi. (4.2 pav.)

Anglies dioksido emisija buvo matuojama kas valandą visų trijų panaudos tipu dirvožemyje, siekiant fiksuoti tiesioginį duomenų ryši su atmosferos sąlygomis.

Pasirinkus norimą analizès vieta, programavimo konsolè sujungiama su dirvožemio kvépavimo kamera. I parinktą vietą ismeigiamas metalinis žiedas ir prie jo pritvirtinama kamera. Žiedas ismeigiamas statmenai dirvožemiui ir paliekamas 20 minučių. Matavimo metu kameroje negali būti žolių ar kitų davikliams galinčių pakenkti elementų. Šalia žiedo smeigiamas dirvos temperatūros jutiklis, matuojantis dirvožemio temperatūrą $5 \mathrm{~cm}$ gylyje, ir sustumiamasis vamzdis. Pastaruoju prietaisas tiekia anglies dioksidą iš atmosferos 3 metrų aukštyje. Toks aukštis parinktas, kad matavimui įtakos daryti negalètų matuojantis asmuo. Ma- 
tuojama 20-30 minučiuc, stebint anglies dioksido emisijos svyravimus. Duomenys automatiškai ịrašomi į atminties laikmeną

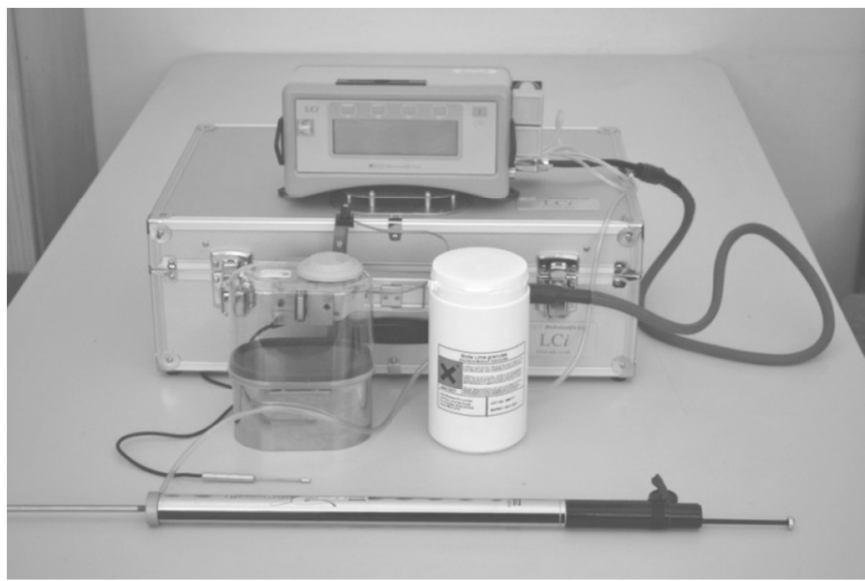

4.2 pav. Anglies dioksido emisijų išsiskyrimo iš dirvožemio matavimo prietaisas ADC SRS-1000

Fig. 4.2. Carbon dioxide emissions from the soil release measurement device ADC SRS-1000

Konsolę sudaro gaubtas su ventiliacijos ir slègio vožtuvu. Temperatūros zondas skirtas išsamiai analizei. Jis įsmeigiamas i dirvožemi šalia gaubto. Nerūdijančio plieno žiedas skirtas matavimo kamerai i dirvožemi ismeigti ir tvirtinti. Nominalus gaubto plotas $-111 \mathrm{~cm}^{2}$; tūris $-995 \mathrm{~cm}^{3}$. Jeigu gaubto dangtis ismeigiamas i dirvožemi, efektyvus jo tūris sumažèja. Faktinị tūri galima apskaičiuoti esančios dirvožemyje dangčio dalies aukštį dauginant iš dirvožemio ploto ir ši skaičių atimant iš gaubto tūrio.

Tyrimu metu žiedas ismeigiamas iki žymos, todèl maksimali jo talpa lygi $682,5 \mathrm{~cm}^{3}\left(\sim 682 \mathrm{~cm}^{3}\right)$. Bendras maksimalus analizuojamas tūris apskaičiuojamas gaubto tūri sudejjus su apskaičiuotuoju žiedo tūriu, kuris yra lygus 1650 $\mathrm{cm}^{3}$. Bendras tyrimo metu analizuojamas tūris, kai nuo žiedo ribų lieka du centimetrai, yra $1163 \mathrm{~cm}^{3}$. (Prarastas tūris, kai neįsmeigti $2 \mathrm{~cm}$, yra lygus $195 \mathrm{~cm}^{3}$. Analizuojamas tūris nustatomas prie nominalaus $968 \mathrm{~cm}^{3}$ pridejus prarastaji $195 \mathrm{~cm}^{3}$.)

I dirvožemio gaubtą patenka ịprastas oras. Gaubtas ileidžia analizuojamą orą i kamerą tokiu pat būdu kaip ir standartinèse kamerose. Oro srautas, patenkantis i dirvožemio gaubta, kontroliuojamas funkcijos „Uset“, kuri yra konfigūracijos „LCi/Pro“ meniu. Srauto dydis tyrimo metu gali nežymiai kisti, iki 200 ribos. Oro perteklius nukreipiamas i gaubta, o slègio vožtuvas užtikrina, kad 
kameroje būtų palaikomas normalus oro slègis, kuris netrikdytų dujų apykaitos vykstant dirvožemio ir oro sąveikai.

Gaubto viduje esančio oro temperatūra ir drègmè kontroliuojama iprastu būdu - kameros jutikliais $T_{\text {ch }}, E_{\text {an }}, E_{\text {ref. }}$ Dirvožemio temperatūra matuojama specialiu temperatūros jutikliu, kuris sujungtas su rankenos lizdu. Jis turi tą pati termorezistorių kaip ir lapų temperatūros zondas, kuris pasižymi žema nelinijine reakcija, kompensuojama analizatoriaus programinès ịangos.

Tyrimo metu žiedas i dirvožemi îsmeigiamas tokiu gyliu, kokio reikia difuzijai pašalinti. Jeigu, tarkim, dirvožemis purus, žiedą reikia istumti kuo giliau, kad būtų sumažintas dujų prasiskverbimas ir užtikrinta geresnè gaubto atrama. Žiedą ịsmeigus, uždedamas gaubtas. Pradejjus matuoti, atliekamas srauto kontrolès kalibravimas. Tai svarbu, nes dèl padidejjusio gaubte dirvožemio kiekio gali pakisti dujų nusėdimo laikas, ypač jeigu srautas mažas. Jeigu nusėdimo laikas trumpas, duomenys gali būti netikslūs. Bandymai parodè, kad kalibravimą geriausia atlikti tada, kai nustatytas srautas yra $100 \mu$ mols $\mathrm{s}^{-1}$ ir laiko dujoms nusésti pakanka esant bet kokiam srauto greičiui, didesniam už $100 \mu$ mols s ${ }^{-1}$. Kalibravimas kartojamas tik tada, jeigu srauto greitis nesiekia $100 \mu \mathrm{mols} \mathrm{s}{ }^{-1}$.

Perskaičiuoti galima pagal srauto matavimus, naudojantis $\mathrm{U}$ ir patenkančio i kamerą $\mathrm{CO}_{2}$ koncentracija $\mathrm{C}_{\text {ref, }}$, bei išeinančio iš kameros $\mathrm{CO}_{2}$ koncentracija $\mathrm{C}_{\mathrm{an}}$.

$$
\begin{gathered}
C_{a n}-C_{r e f}=\Delta C, \\
C_{s}=\Delta C \cdot U m o l, \\
U m o l=\frac{U}{10^{6}},
\end{gathered}
$$

čia $\mathrm{C}_{\text {ref }}$ - standartinis $\mathrm{CO}_{2}$ koncentracijos vienetas, $\mu$ mols s ${ }^{-1} ; \mathrm{C}_{\mathrm{an}}-$ analizès $\mathrm{CO}_{2}$ koncentracijos vienetas, $\mu$ mols s ${ }^{-1}$; $U-$ srautas i kamera, $\mu$ mol s ${ }^{-1}$.

Darbui lauke naudojamas teleskopinis zondas, kuriuo oras tiekiamas i prietaisą. Zondas sudarytas iš teleskopinio vamzdžio ir kuoliuko, naudojamo zondui tvirtinti dirvožemyje. Zondo paskirtis - tiekti šviežią ora, kuris nebūtų paveiktas matuotojo ar vietos augalijos. Zondo aukštis -4 metrai.

Prieš paleidžiant prietaisa, issitikinama, ar natrio kalcio silikato užpildas nepakeite spalvos. Naujo, ką tik užpilto, natrio kalcio silikato užpildo spalva yra šviesiai žalsva. Pakitęs užpildas - gelsvai rudas. 


\subsection{Anglies dioksido emisijų natūriniai tyrimai skirtingos panaudos dirvožemiuose Neries regioniniame parke duomenys ir analizè}

Tyrimai atlikti rugpjūčio, rugsèjo mènesiais. Matavimo metu aplinkos oro temperatūra kito nuo 8,7 iki 18,6 laipsnio. Analize buvo siekiama ịvertinti emisijos dydžius ir tam itaką darančius faktorius. Anglies dioksido išsiskyrimui itakos turi tokie veiksniai, kaip drègmè, temperatūra, mikroorganizmu aktyvumas, dirvožemio tipas. Buvo analizuojami smèlžemiai. Smėlžemiuose gausu žvirgždo ir smèlio - tokie yra tipiniai pušynai, kurių dirvožemio paviršiuje susikaupęs 20$30 \mathrm{~cm}$ puveningas sluoksnis.

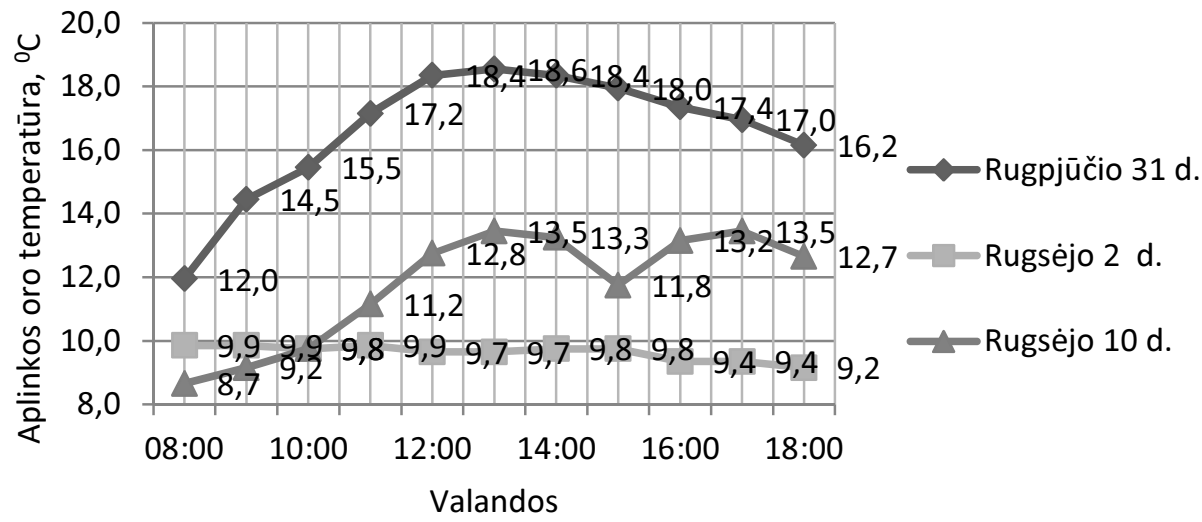

4.3 pav. Aplinkos oro temperatūros kitimas anglies dioksido emisijos iš dirvožemio tyrimų metu $2010 \mathrm{~m}$. rudeni

Fig. 4.3. Ambient air temperature variation of carbon dioxide emissions investigation from the soil sites in 2010 Autumn

Stebint aplinkos rodiklius nustatyta, kad rugpjūčio 31 dieną aplinkos oro temperatūra kito nuo $12{ }^{\circ} \mathrm{C}$ iki $18,6{ }^{\circ} \mathrm{C}$ laipsnių. (4.3 pav.) Aplinkos oro temperatūros pikas buvo nustatytas $11-17$ valandomis. Šiomis valandomis vidutinè aplinkos oro temperatūra buvo $17,9^{\circ} \mathrm{C}$. Rugsèjo 2 dieną aplinkos oro temperatūra buvo žemiausia per visą matavimų laikotarpi $-8,7{ }^{\circ} \mathrm{C}$, tačiau nuo 10 valandos ryto, sumažejus debesuotumui, pakilo ir dieną svyravo apie $12,4{ }^{\circ} \mathrm{C}$. Matavimo metu aplinkos oro temperatūra kelis kartus buvo šoktelejusi iki $13{ }^{\circ} \mathrm{C}$. Rugsèjo 10 dieną aplinkos oro temperatūra pasiskirste tolygiai visos dienos metu ir kito nuo $9,2{ }^{\circ} \mathrm{C}$ iki $9,9^{\circ} \mathrm{C}$. Tyrimo metu buvo apsiniaukę, stiprus vejjas ir didele tikimybè lietaus. 


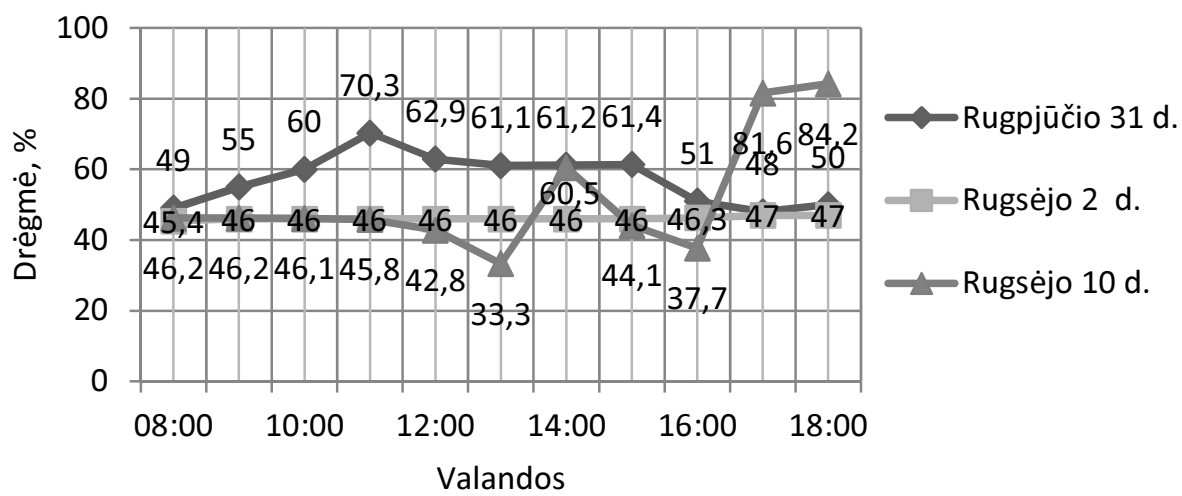

4.4 pav. Aplinkos oro drègmès kitimas anglies dioksido emisijos iš dirvožemio tyrimų metu $2010 \mathrm{~m}$. rudens sezonu

Fig. 4.4. Ambient air humidity variation of carbon dioxide emissions investigation from the soil sites in 2010 Autumn

Aplinkos drègmès stebejjimas leido įvertinti aplinkos sąlygas ir lietaus tikimybę. Literatūros duomenys rodo, kad net silpnas lietus gali sumažinti anglies dioksido emisijos kiekius. Padidejusi drègmè dirvožemyje mažina poringumąo o tai neleidžia išsiskirti anglies dioksidui. Be to, didesnè drègmè lètina mikroorganizmų veiklą ir mažina dirvožemio temperatūrą. $20 \%$ dirvožemio drègnis, atsižvelgiant i tipa, laikomas optimaliu: esant tokiam drègmès kiekiui, mikroorganizmai aktyviausiai skaido organines medžiagas. Mažesnè dirvožemio temperatūra taip pat skatina dirvožemio oro tirpumą vandens plèvelèse ir kapiliaruose.

Aplinkos drègmès duomenys rodo, kad rugpjūčio 31 d. aplinkos oro drègmès vidutinè reikšmė buvo $62,4 \%$. Apžvelgiant ankstesnes dienas, nustatyta, kad dirvožemis nebuvo visai išdžiūvęs po praejusio lietaus. Literatūroje nurodoma, kad matuoti geriausia praèjus kelioms dienoms po lietaus, kai dirvožemio drégmè normalizuojasi. Rugsèjo $2 \mathrm{~d}$. tyrimų metu aplinkos oro drègmè kito mažai apie $46 \%$. Rugsèjo $10 \mathrm{~d}$. aplinkos oro drègmès kitimas buvo didžiausias ir matavimui artejjant prie pabaigos pradejo lynoti (17-18 val.).

Analizuojant drègmès rodiklius matyti, kad dirvožemio drègnumas atskirais dienos laikotarpiais buvo didesnis už aplinkos oro drėgnumą. Tyrimo metu rugpjūčio 31 d. dirvožemio drégnumas siekè nuo 39,9\% iki 65,1\%. Didžiausias drègmès kiekis dirvožemyje nustatytas tyrimų pradžioje. Nuo 8 iki 13 valandos dirvožemio drégnis svyravo apie $57,9 \%$ vertę, o nuo 13 val. krito iki $43,5 \%$ vidutinès vertès. 


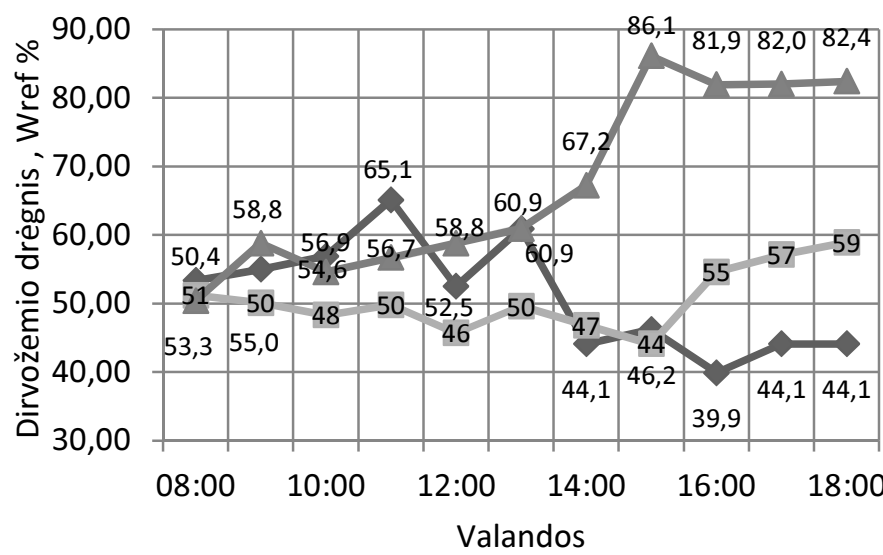

Rugpjūčio $31 \mathrm{~d}$.

- Rugsejo $2 \mathrm{~d}$. Rugsèjo $10 \mathrm{~d}$.

4.5 pav. Drivožemio drėgnis nustytas anglies dioksido emisijų matuokliu

Fig. 4.5. Soil moisture mesuremed at carbon dioxide emissions measuring device

Iš tyrimo rodikliu matyti, kad aplinkos oro temperatūra išliko ganètinai stabili ir vakarop nukrito tik apie $2{ }^{\circ} \mathrm{C}$, tuo tarpu aplinkos oro drégnumas nukrito $10 \%$. Iš to galima daryti išvada, kad didžiausia anglies dioksido emisija turejo būti dienos viduryje ir vakarop.

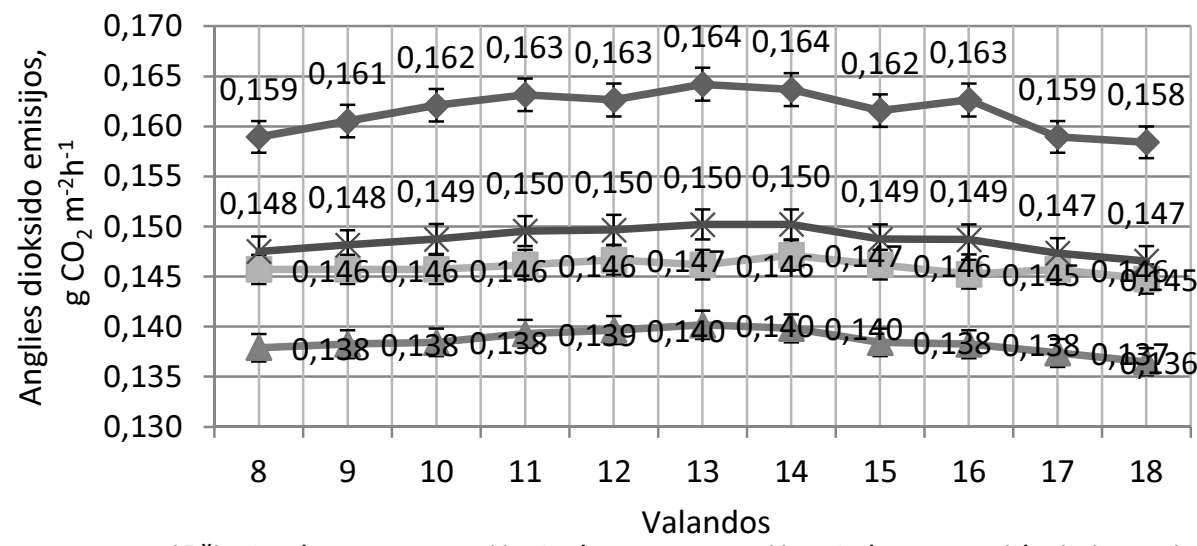

$\multimap$ Rugpjūčio $31 \mathrm{~d}$. $\leftarrow$ Rugsèjo $2 \mathrm{~d}$. $\leftarrow$ Rugsèjo $10 \mathrm{~d} . *$ Vidutinè vertè

4.6 pav. $\mathrm{CO}_{2}$ emisija pievos dirvožemyje dienos metu 2010 metais rudens sezonu

Fig. 4.6. Daily $\mathrm{CO}_{2}$ emissions from grassland soils the autumn season in 2010 
Iš 4.6 paveikslo matyti, kad anglies dioksido emisija pievos dirvožemyje didžiausia buvo dienos metu. Nuo 15 valandos sumažejus drègniui ir aplinkos oro temperatūrai, anglies dioksido emisija sumažejo tik $0,014 \mathrm{~g} \mathrm{CO}_{2} \mathrm{~m}^{-2} \mathrm{~h}^{-1}$. Tokiam mažam anglies dioksido kitimui ịtakos turi drègmès, aplinkos oro temperatūra bei vejjo greitis. Esant drègmès pertekliui, dalis anglies dioksido ištirpsta vandens intarpuose. Temperatūra tiesiogiai daro įtaką dujų tirpumui vandenyje ir jų plètimosi koeficientui. Vejjo greitis veikia paviršiaus dujų tankị. Esant stipriam vejjui, vyksta intensyvesnis dujų maišymasis. Kadangi anglies dioksidas yra sunkesnis už ora, pučiant stipriam vejjui, anglies dioksidas garuoja intensyviau. Atmosferos slègis taip pat daro poveiki duju pasiskirstymui dirvožemyje: kai jis žemas, dujos kaupiasi; atmosferos slègiui padidejjus, vyksta dujų sklaida. Temperatūros įtaka anglies dioksido kiekiui dirvožemyje pasireiškia tuo, kad jai sumažèjus mikroorganizmų veikla taip pat suletejja ir net gali nutrūkti. Lemiamą vaidmeni vaidina ir drègmé, jos perteklius taip pat stabdo mikroorganizmų veiklą. Kadangi matavimai atlikti rudens sezonu, esant borealiniam klimatui, kritulių kiekis yra 1,6 karto didesnis už išgaravima. Dominuoja medžiagų išplovimas ir išnešimas. Rudens sezonu vandens išgaravimas susilygina su patenkančiais i dirvožemį krituliais arba yra už kritulius net menkesnis.

Pievos dirvožemyje anglies dioksido matavimai atlikti tyrimo vietoje, pavaizduotoje 4.1 paveiksle. Matavimų metu aplinkos oro temperatūra kito nuo $8,7{ }^{\circ} \mathrm{C}$ iki $18{ }^{\circ} \mathrm{C}$ laipsnių šilumos. Matavimo metu buvo mažai debesuota, nelijo. Aukščiausia nustatyta aplinkos temperatūra $18-18,6^{\circ} \mathrm{C}$ nuo 13 iki 16 valandos. (4.3 pav.) Šiuo laiko tarpu taip pat nustatyta didžiausia anglies dioksido emisija, ji kito nuo 0,163 iki $0,162 \mathrm{~g} \mathrm{CO}_{2} \mathrm{~m}^{-2} \mathrm{~h}^{-1} .8$ valandą ryto anglies dioksido emisija buvo $0,159 \mathrm{~g} \mathrm{CO}_{2} \mathrm{~m}^{-2} \mathrm{~h}^{-1}$ (rugpjūčio $31 \mathrm{~d}$.), vakare buvo lygi $0,158 \mathrm{~g} \mathrm{CO}_{2} \mathrm{~m}^{-2} \mathrm{~h}^{-1}$. Skirtumas tarp ryte ir vakare atliktų tyrimų yra $\sim 0,001 \mathrm{~g} \mathrm{CO}_{2} \mathrm{~m}^{-2} \mathrm{~h}^{-1}$. Kitą dieną vidutinis išsiskyrusių anglies dioksido dujų kiekis prilygo $0,146 \mathrm{~g} \mathrm{CO}_{2} \mathrm{~m}^{-2} \mathrm{~h}^{-1}$ (rugsejjo 2 d.). (4.6 pav.) Kaip matyti, palyginti su pirmos dienos matavimais, anglies dioksido kiekis antrą dieną sumažejo $0,016 \mathrm{~g} \mathrm{CO}_{2} \mathrm{~m}^{-2} \mathrm{~h}^{-1}$. Aplinkos oro temperatūra antrą dieną buvo mažesnè $9,2-9,9{ }^{\circ} \mathrm{C}$ laipsnio. Nustatytas dirvožemio drègnis tuomet buvo 51,1\% (8-13 val.). Didžiausia anglies dioksido emisija nustatyta $13-16$ valandomis $-0,160 \mathrm{~g} \mathrm{CO}_{2} \mathrm{~m}^{-2} \mathrm{~h}^{-1}$. Šiomis valandomis taip pat nustatyti dirvožemio drègnio skirtumai: drègnumas pasikeitè nuo 48\% iki 54\%. Nuo 16 valandos fiksuotas anglies dioksido emisijos mažejjimas ir dirvožemio drègnio šuolis iki $58 \%$. Tyrimo metu buvo protarpiais debesuota, tačiau nelijo, aplinkos oro temperatūra kito nuo $8,7^{\circ} \mathrm{C}$ iki $13,5^{\circ} \mathrm{C}$ laipsnio (rugsèjo $10 \mathrm{~d}$.). Gauti duomenys yra labai maži, palyginti su 1 ir 2 kreivemis. Vidutinis išsiskyrusio anglies dioksido kiekis buvo $0,142 \mathrm{~g} \mathrm{CO}_{2} \mathrm{~m}^{-2} \mathrm{~h}^{-1}$. Dieną prieš matavimą lijo. Matavimo metu buvo apsiniaukę ir trumpai nulijo. Dirvožemio drègmé tyrimo metu buvo $25,1 \%$. Didžiausia anglies dioksido emisija fiksuota $13-15$ valandomis - nuo 0,142 iki $0,146 \mathrm{~g} \mathrm{CO}_{2} \mathrm{~m}^{-2} \mathrm{~h}^{-1}$. Kaip matyti iš atliktų tyrimų, nu- 
statyta priklausomybė nuo aplinkos oro temperatūros ir iš dirvožemio išsiskiriančio anglies dioksido kiekio. Taip pat analizuojant gautus duomenis nustatyta, kad dirvožemyje esanti drègmé labai sumažina anglies dioksido emisiją. Analizuojamo ploto dirvožemio drégnumui esant $58 \%$, vidutinè anglies dioksido emisija sudarè $0,162 \mathrm{~g} \mathrm{CO}_{2} \mathrm{~m}^{-2} \mathrm{~h}^{-1}$, o esant $86 \%$ drègniui $-0,139 \mathrm{~g} \mathrm{CO}_{2} \mathrm{~m}^{-2} \mathrm{~h}^{-1}$. Dirvožemio drègnumui padidejus 1,1 karto, anglies dioksido emisija sumažejo 1,2 karto. Vidutinių reikšmių kreiveje pateikiami vidutiniai anglies dioksido išsiskyrimo kiekiai, kurie tyrimų metu kito nuo $0,147 \mathrm{iki} 0,150 \mathrm{~g} \mathrm{CO}_{2} \mathrm{~m}^{-2} \mathrm{~h}^{-1}$.

Lietuvos agrarinių ir miškų mokslo centro duomenimis, organinio ūkininkavimo sistemoje žieminių kviečių pasèlio dirvožemis į atmosferą per dieną išskyrè vidutiniškai $8,8 \mathrm{C} \mathrm{g} \mathrm{m}^{2}$; raudonujų dobilų žolyno dirvožemis $-9 \mathrm{C} \mathrm{g} \mathrm{m}^{2}$; vasarinių miežių pasėlio dirvožemis $-4,7 \mathrm{C} \mathrm{g} \mathrm{m}^{2}$. Intensyvaus ūkininkavimo sistemoje - atitinkamai 5,5;6,5;4,1 $\mathrm{C} \mathrm{g} \mathrm{m}^{2}$. Pagal atliktus tyrimus nustatyta, kad pievos dirvožemyje esantis anglies dioksido kiekis tesudaro $1,8 \mathrm{~g} \mathrm{CO}_{2} \mathrm{~m}^{-2}$ per diena, o ariamame dirvožemyje $-3,7 \mathrm{~g} \mathrm{CO}_{2} \mathrm{~m}^{-2}$ per dieną (Feizienè 2008, 2009).

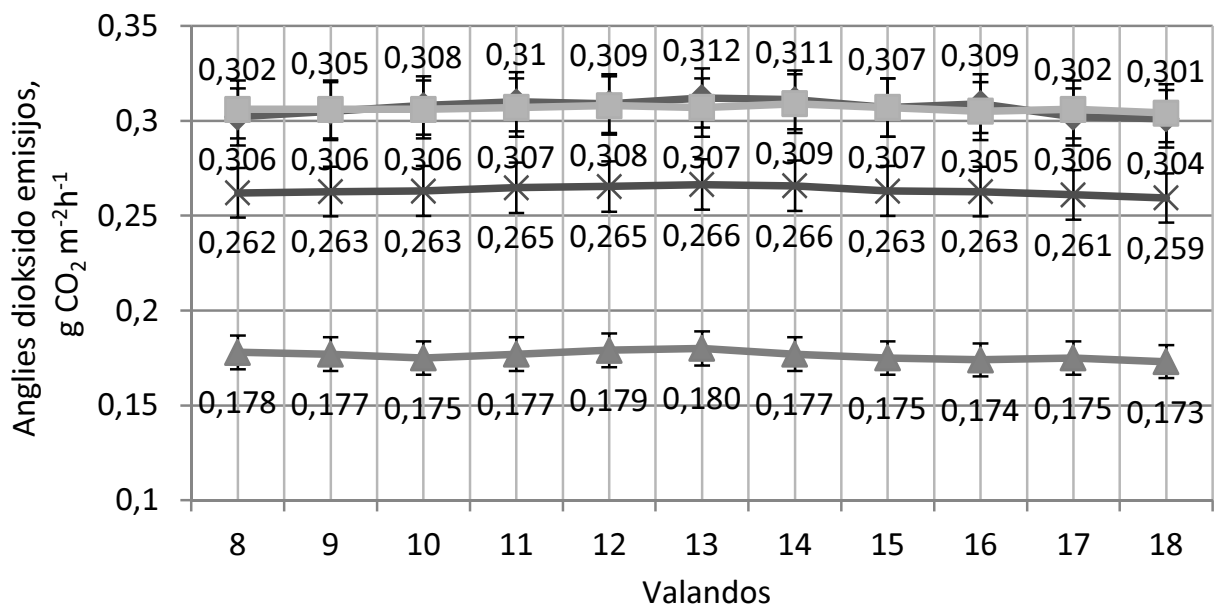

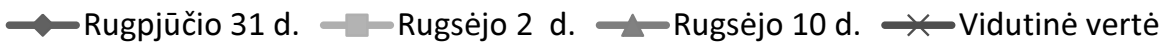

4.7 pav. $\mathrm{CO}_{2}$ išsiskyrimas ariamame dirvožemyje dienos metu $2010 \mathrm{~m}$. rudens sezonu

Fig. 4.7. Daily $\mathrm{CO}_{2}$ emissions of arable soils the autumn season in 2010

Lietuvos agrarinių ir miškų mokslo centras atliko tyrimus vidutinio sunkumo priemolio, giliau - karbonatinio seklaus glejjiško rudžemio, kuriame daugiau nei 10 metų taikoma skirtinga žemdirbystè. Ivertinus augalų dangą, nustatyta, kad ji lèmé vidutiniškai $68 \%$ didesnị dirvožemio paviršiaus kvėpavimą negu 
vasarinių augalų danga ir 25 kartus didesnị kvejpavimą negu juodasis pūdymas. Atsižvelgiant $\mathfrak{i}$ Lietuvos žemdirbystės tyrimus, galima daryti prielaida, kad anglies dioksido emisija ariamame dirvožemyje yra didesnè negu pievos dèl intensyvaus dirbimo, tai pat dẻl augalų dangos (Feizienè 2008).

Ariamo dirvožemio plote anglies dioksido emisija kito nuo 0,301 iki $0,312 \mathrm{~g} \mathrm{CO}_{2} \mathrm{~m}^{-2} \mathrm{~h}^{-1}$. (Rugpjūčio $31 \mathrm{~d}$.; 4.7 pav.) Tyrimo metu aplinkos oro temperatūra kito nuo $12{ }^{\circ} \mathrm{C}$ iki $18,6{ }^{\circ} \mathrm{C}$ laipsnių. Tačiau anglies dioksido emisija ariamame dirvožemyje nekinta kaip pievos dirvožemyje - ariamo dirvožemio emisija buvo nustatoma tolygi. Didžiausi anglies dioksido kiekiai nustatyti 1114 valandų laikotarpiu, jie kito nuo 0,31 iki $0,312 \mathrm{~g} \mathrm{CO}_{2} \mathrm{~m}^{-2} \mathrm{~h}^{-1}$. Ryte nustatytas anglies dioksido kiekis buvo 0,302 $\mathrm{g} \mathrm{CO}_{2} \mathrm{~m}^{-2} \mathrm{~h}^{-1}$, o vakare $-0,301 \mathrm{~g} \mathrm{CO}_{2} \mathrm{~m}^{-2} \mathrm{~h}^{-1}$. Dirvožemio drègnumas eksperimento metu sudare $49 \%$. Antroje kreiveje pateikiami kitos dienos matavimo duomenys, kai aplinkos oro temperatūra buvo žemesnè ir tesudare $9,2-9,9{ }^{\circ} \mathrm{C}$. Kaip matyti, anglies dioksido emisija sumažèjo vos $0,001 \mathrm{~g} \mathrm{CO}_{2} \mathrm{~m}^{-2} \mathrm{~h}^{-1}$ nuo vidutinès reikšmès. Didžiausias anglies dioksido emisijos kiekis nustatytas $11-15$ valandomis $-0,309 \mathrm{~g} \mathrm{CO}_{2} \mathrm{~m}^{-2} \mathrm{~h}^{-1}$, o ryte ir vakare atliktų tyrimų metu skyrèsi labai nedaug - atitinkamai nuo 0,306 iki 0,304 g $\mathrm{CO}_{2} \mathrm{~m}^{-2} \mathrm{~h}^{-1}$. Dirvožemiui i̇mirkus, $\mathrm{CO}_{2}$ emisija sumažèjo perpus (Rugsèjo $10 \mathrm{~d}$.). Dirvožemio i̇mirkimo gylis buvo apie $8 \mathrm{~cm}$. Didžiausi anglies dioksido kiekiai čia nustatyti 12-14 valandomis. Rytiniai ir vakariniai matavimai rodo, kad anglies dioksido emisijos kitimo ribos buvo mažos - nuo $0,178 \mathrm{~g} \mathrm{CO}_{2} \mathrm{~m}^{-2} \mathrm{~h}^{-1}$ ryte iki $0,173 \mathrm{~g} \mathrm{CO}_{2} \mathrm{~m}^{-2} \mathrm{~h}^{-1}$ vakare. Dirvožemio drègnis sudarè $84 \%$ (15-18 val.). Kaip ir pievos dirvožemyje, padidejus drègniui anglies dioksido emisija smarkiai sumažèjo. Vidutiniškai anglies dioksido emisija ariamame dirvožemyje yra didesnè negu pievoje 1,9 karto.

Kritulių kiekio padidèjimas dirvožemyje taip pat skatina intensyvesnę anglies dioksido emisiją. Lietuvos žemdirbystès institute atliktais tyrimais įrodyta, kad per augalų vegetacijos laikotarpi kritulių kiekiui padidejus iki 11,2 mm dirvožemio kvèpavimas padidèjo vidutiniškai $0,041 \mathrm{~g} \mathrm{C} \mathrm{m}^{-2}$ per dieną, o intensyvios žemdirbystès plotuose $-0,038 \mathrm{~g} \mathrm{C} \mathrm{m}^{-2}$ per dieną.

Darytina prielaida, kad drègmès kiekis yra svarbus anglies dioksido emisijai dirvožemyje. Tačiau tik augalų vegetacijos periodu jis gali padidinti anglies dioksido emisija, nes vegetacinio periodo pabaigoje, esant žemai temperatūrai, tiek dèl mikroorganizmų veiklos, tiek dèl augalų augimo anglies dioksido emisija gali sumažèti.

Miško dirvožemio anglies dioksido emisija buvo tirta mišraus miško plote su vyraujančiais spygliuočiais. Miškas neretintas, vietovė gana kalvota, tankus hidrografinis tinklas. Tyrinejjant bendrosios anglies kieki dirvožemyje, buvo nustatyti žymūs jos skirtumai, kuriuos, be kitų galimų veiksnių, veikè vandens plokštuminè erozija. Anglies dioksido emisija čia gali būti veikiama paviršinès miško paklotès, todèl atliekant matavimus ji buvo šalinama iki dirvožemio. Ke- 
lios dienos prieš tyrimus nelijo ir tyrimo metu dirvožemis nebuvo įdrèkęs. Dieną gauti duomenys išsiskiria stabilumu: anglies dioksido emisija kito nuo 0,259 iki $0,262 \mathrm{~g} \mathrm{CO}_{2} \mathrm{~m}^{-2} \mathrm{~h}^{-1}$. (4.8 pav.).

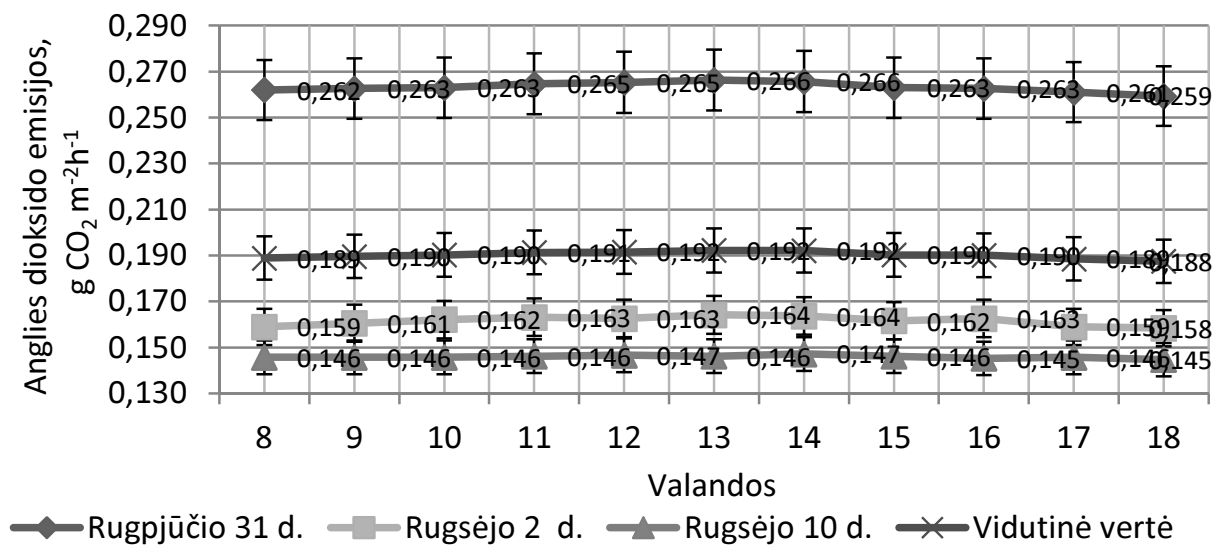

4.8 pav. $\mathrm{CO}_{2}$ išsiskyrimas miško dirvožemyje dienos metu $2010 \mathrm{~m}$. rudens sezonu

Fig. 4.8. Daily $\mathrm{CO}_{2}$ emissions of forest soil the autumn season in 2010

Aktyviausia emisija nustatyta $13-15$ valandomis $-0,266 \mathrm{~g} \mathrm{CO}_{2} \mathrm{~m}^{-2} \mathrm{~h}$. Tyrimo metu analizuojamo dirvožemio drègnis, aplinkos temperatūrai esant $12-18,6{ }^{\circ} \mathrm{C}$ laipsnių, buvo $5,2 \%$. Atliekant tyrimus, kai aplinkos oro temperatūra buvo $9,2-9,9{ }^{\circ} \mathrm{C}$ laipsnių, dirvožemio drègnis sudare $44,1-58,9 \%$. Anglies dioksido emisija esant mažesnei aplinkos temperatūrai lyginta su rugpjūčio 31 dienos duomenimis. Rugsejo 2 dienos duomenys atliekant tyrimus kito nuo 0,158 iki $0,164 \mathrm{~g} \mathrm{CO}_{2} \mathrm{~m}^{-2} \mathrm{~h}^{-1}$; anglies dioksido emisijos didejimas nustatytas tarp 8 ir 12 valandos, jis sudare $0,004 \mathrm{~g} \mathrm{CO}_{2} \mathrm{~m}^{-2} \mathrm{~h}^{-1}$. Rugsejjo 10 dienos duomenys kito nuo 0,145 iki $0,147 \mathrm{~g} \mathrm{CO}_{2} \mathrm{~m}^{-2} \mathrm{~h}^{-1}$; didžiausia anglies dioksido emisija nustatyta tarp 13 ir 15 valandos $-0,146 \mathrm{~g} \mathrm{CO}_{2} \mathrm{~m}^{-2} \mathrm{~h}^{-1}$. Apibendrinus atliktus tyrimus matyti, kad didžiausią itaką anglies dioksido emisijai dare temperatūra. Vidutinè anglies dioksido emisija kito nuo 0,148 iki $0,147 \mathrm{~g} \mathrm{CO}_{2} \mathrm{~m}^{-2} \mathrm{~h}^{-1}$. Didžiausias kitimas nustatytas tarp 11 ir 15 valandos $-0,150 \mathrm{~g} \mathrm{CO}_{2} \mathrm{~m}^{-2} \mathrm{~h}^{-1}$. Beveik visais analizuojamais atvejais anglies dioksido emisija nuo 8 val. ryto iki 18 val. vakaro kinta mažame intervale.

Iš skirtingos panaudos plotų emituojamo anglies dioksido kiekio nustatyta, kad didžiausia emisija buvo ariamame dirvožemyje - $0,263 \mathrm{~g} \mathrm{CO}_{2} \mathrm{~m}^{-2} \mathrm{~h}^{-1}$; pievoje $-0,1490,139 \mathrm{~g} \mathrm{CO}_{2} \mathrm{~m}^{-2} \mathrm{~h}^{-1}$; miške $-0,139 \mathrm{~g} \mathrm{CO}_{2} \mathrm{~m}^{-2} \mathrm{~h}^{-1}$. 
Apskaičiuota, kad dirbamosiose pasaulio dirvose priešistoriniais laikais anglies kiekis dirvožemyje buvo $222 \mathrm{Pg}$, o mūsų dienomis dèl intensyvaus dirvožemių naudojimo sumažèjo iki $168 \mathrm{Pg}$. Nustatyta, kad beveik 10 proc. viso atmosferos anglies dioksido išskiriama iš dirvožemio. Mokslininkai mano, kad priešistoriniais laikais anglies dioksido kiekis Žemès atmosferoje buvo 270 ppm, $1990 \mathrm{~m}$. padidejo iki 350 ppm, o $2004 \mathrm{~m}$. jau siekè 370 ppm (Feiziené 2008).

Taip pat manoma, kad augalų šaknų kvėpavimas sudaro apie 50 proc. viso dirvožemio kvėpavimo. Jo intensyvumas priklauso nuo auginamų augalų bei jų auginimo sąlygų. Taigi sudarant atitinkamas aplinkos salygas ir auginant skirtingus augalus galima kontroliuoti anglies emisiją. Nustatyta, kad dirvožemio kvèpavimą lemia dirvoje esantis anglies kiekis ir dirvožemio drègmè. Be to, didèjant oro temperatūrai ir mažejant dirvos drègmei, dirvožemio kvẻpavimas lètejja. O laikotarpiais, kai dirvožemio drègmès kiekis viršija $200 \mathrm{~g} \mathrm{~kg}^{-1}(20 \%)$, dirvožemio kvèpavimas labai priklauso nuo dirvos temperatūros. Intensyviausiai dirva pradeda kvèpuoti vèlai kovo mènesi ir tai trunka iki vasaros, per vasarą bei ankstų rudeni. Vieni autoriai teigia, kad net ir negausūs trumpalaikiai lietūs suaktyvina anglies dvideginio išsiskyrimą (taip pat ir kvépavima) iš dirbamosios dirvos, o kiti - kad krituliai gali tik trumpam (kelioms dienoms) suaktyvinti anglies dvideginio išsiskyrima, o po lietaus maksimali anglies dioksido emisija nebūna tokia didelè, kaip manoma (Feizienè 2009).

Dirvožemio kvèpavimą lemia augalų dangos tipas. Labiau dirva kvėpuoja daugiamečių žolių lauke negu laukuose, kuriuose auga žemès ūkio augalai. JAV nustatyta, kad dirvose, kuriose auga augalai, dirvožemio kvépavimas $\sim 20 \%$ didesnis negu juodajame pūdyme. Atskirais atvejais aukštesnè dirvos temperatūra juodojo pūdymo lauke didina dirvožemio kvèpavima, todèl paliekant pūdymus anglies kaupimasis dirvoje mažèja ir šis būdas žemès ūkyje rekomenduotinas tik tuo atveju, jeigu negalima naudoti herbicidų nuo piktžolių (Feiziené 2008). Taigi, augalų rūšis turi nedidelę itaką bendram dirvožemio kvẻpavimo intensyvumui, o augalų dangos heterogeniškumas, nevienodas šaknų pasiskirstymas dirvoje ir dirvožemio fizinių savybių ivvairovè tame pačiame lauke gali lemti didelius dirvožemio kvėpavimo intensyvumo skirtumus (Žemės dirbimo... 2010).

Nagrinejjant anglies dioksido emisijas nustatyta, kad jos patikimai koreliuoja su aplinkos temperatūra. Pievos dirvožemio anglies dioksido emisijos su aplinkos temperatūra koreliavo patikimai $\mathrm{r}=0,6$. Miško dirvožemio anglies dioksido koreliacijos koeficientas lygus $r=0,5$, o ariamo dirvožemio $r=0,6$. Santykinès aplinkos drègmès ir anglies dioksido koreliacijos koeficientai buvo neigiami. Tai rodo, kad šie parametrai yra atvirkščiai priklausomi. Pievos dirvožemio anglies dioksido emisijų koreliacijos koeficientas siekè $r=-0,3$, o miško ir ariamo dirvožemio $\mathrm{r}=-0,4$. Be to, aplinkos santykinè drégmè yra tiesiogiai priklausoma nuo aplinkos oro temperatūros. Dirvožemio drègnio analizè parodè, kad anglies 
dioksido emisijo,s taip pat atvirkščiai priklausomo nuo drègmės kiekio dirvožemyje. Tačiau koreliacinis ryšys buvo stipresnis nei su aplinkos santikine drègme. Pievos dirvožemio $r=-0,4$, miško $r=-0,5$, o ariamo dirvožemio $r=-0,5$.

Duomenų statistinè analizè atlikta naudojantis kompiuterine programa Statistica 7 .

\subsection{Ketvirto skyriaus išvados}

1. Analizuojant anglies dioksido emisijų kiekius skirtingos panaudos dirvožemiuose nustatytas anglies dioksido emisijų kitimas. Žvelgiant ị gautus duomenis nustatyta, kad daugiausiai anglies dioksido išsiskiria ariamame dirvožemyje $0,263 \mathrm{~g} \mathrm{CO}_{2} \mathrm{~m}^{-2} \mathrm{~h}^{-1}$,o pievoje $0,149 \mathrm{~g} \mathrm{CO}_{2} \mathrm{~m}^{-2} \mathrm{~h}^{-1}$ ir miške $0,139 \mathrm{~g} \mathrm{CO}_{2} \mathrm{~m}^{-2} \mathrm{~h}^{-1}$.

2. Dirvožemio anglies dioksido emisijos turi tiesioginę priklausomybę nuo aplinkos oro temperatūros. Iš atliktų tyrimo rezultatų matyti, kad anglies dioksido emisijos sumažejjusios nuo 1,1 iki 1,6 kartų, esant temperatūros sumažèjimui nuo 18,6 iki $8,7^{\circ} \mathrm{C}$ laipsnių.

3. Nustatyta, kad dèl dirvožemio drègmès anglies dioksido emisijos mažèja. Natūriniais tyrimais įrodyta, kad pievos dirvožemyje drègniui padidejjus 1,1 karto anglies dioksido emisijos sumažèjo 1,2 karto. Ariamo dirvožemio drègniui padidejus 1,4 karto, anglies dioksido emisijos sumažejo 1,7 karto. Miško dirvožemio drègniui padidejjus 1,4 karto, anglies dioksido emisijos sumažèjo 1,8 karto.

4. Nagrinèjant anglies dioksido emisijas nustatyta, kad jos patikimai koreliuoja su aplinkos temperatūra. Pievos dirvožemio anglies dioksido emisijos su aplinkos temperatūra koreliavo patikimai $r=0,6$. Miško dirvožemio anglies dioksido koreliacijos koeficientas lygus $\mathrm{r}=0,5$, o ariamo dirvožemio $\mathrm{r}=0,6$.

5. Santykinès aplinkos drègmès ir anglies dioksido koreliacijos koeficientai buvo neigiami. Tai rodo, kad šie parametrai yra atvirkščiai priklausomi. Pievos dirvožemio anglies dioksido emisijų koreliacijos koeficientas siekè $r=-0,3$, o miško ir ariamo dirvožemio $r=-0,4$. Koreliacinis ryšys nuo dirvožemio drègmès buvo stipresnis nei su aplinkos santikine drègme. Pievos dirvožemio $r=-0,4$, miško $r=-0,5$, o ariamo dirvožemio $r=-0,5$. 


$+2$




\section{Dirvožemio bendrosios anglies kiekio kaitos ir anglies dioksido emisiju iš skirtingos panaudos dirvožemių modeliavimas}

Dirvožemio modeliavimas atliekamas naudojantis DNDC modeliavimo programa, kuri plačiai naudojama įvertinti bendrosios anglies kiekiams dirvožemyje ir išsiskiriantiems šiltnamio dujų kiekiams. Vertinimas buvo atliekamas trijų tipų dirvožemiams. Modeliavimo tikslas nustatyti išsiskyrusi anglies dioksido kieki, ivertinti jo kaitą metų bẻgyje atsižvelgiant į klimato kaitą. Vertinimo metu naudojami duomenys gauti analizuojant dirvožemio bendrosios anglies kiekius Neries regioniniame parken (Baltrėnas P., Pranskevičius M., Lietuvninkas A. 2010 m.). 


\subsection{Dirvožemio bendrosios anglies kiekio kitimo, bei $\mathrm{CO}_{2}$ emisijų modeliavimas DNDC modeliu}

DNDC modelis prognozuoja $\mathrm{C}$ ir $\mathrm{N}$ biogeocheminius procesus žemès ūkio ekosistemose. Modeliuojant regioniniu mastu DNDC modelis skaito įvestus duomenis iš duomenų bazès, kurioje informacija gali būti paskirstyta pagal erdvę. Modeliuojant minimalus vertinimas atliekamas imant vienerius metus, o maksimalus įvedamų duomenų kiekis gali apimti 100 metų laikotarpi.

Modelis prognozuoja augalų derlių, anglies kaupimosi, nitratų išplovimo nuostolius, anglies dioksido $\mathrm{CO}_{2}$ išsiskyrimo kiekius. Taip pat ịvertina metano $\mathrm{CH}_{4}$, amoniako $\mathrm{NH}_{3}$, azoto oksido $\mathrm{NO}$, azoto suboksido $\mathrm{N}_{2} \mathrm{O}$ ir diazoto $\mathrm{N}_{2}$ duju emisijas iš žemès ūkio dirvožemių (DNDC... 2010).

Modelis sudarytas iš dviejų komponentų (5.1 pav.). Pirmasis komponentas, sudarytas iš dirvožemio, klimato, žemès ūkio kultūrų augimo ir irimo modelio. Pirmajame komponente atliekami prognoziniai skaičiavimai: dirvožemio temperatūros, drègmès, $\mathrm{pH}$, redokso potencialo (Eh). Ivertinami klimato, dirvožemio, augmenijos ir žmonių veiklos faktoriai. Tai pat nurodomas modeliavimo laikotarpis. Modeliavimo metu buvo nurodoma meteorologiniai Vilniaus duomenys ir nurodoma, kad modeliavimas bus atliekamas 1 metus. Taipogi galima taikyti modeliavimą ir 100 metų. Tai maksimalus šio modelio vertinimo laikotarpis. Modelio minimalus vertinamas laiko tarpas - metai. Todèl modeliuojant būtina metinè meteorologija. Metrologinę duomenų laikmeną sudaro: pradinè eilutè, kurioje nurodomi metai, ir stulpeliai, kuriuose pateikiami kasdieniniai meteorologiniai duomenys (oro temperatūra (vidutinè, minimali, maksimali), kritulių kiekis, saulès radiacija, vejo greitis). Gauti duomenys atspindi anglies dioksido emisijų ir anglies dirvožemyje dinamiką esant blogiausioms sąlygoms. Gauti duomenys pateikiami tekstiniame faile, kuriame duomenis grafikui sudaryti perkeliami i Excel programa. Modeliavimo metu gauti duomenys laikomi byloje, kurią sukuria pati programa. Duomenys pateikiami Excel lentelèse. Prieš modeliavimą teks nurodyti geografinę platumą t. y. buvo nurodyta $52^{\circ}$ atitinkantis Lietuvos platumą.

Modeliavimo metu naudoti Vilniaus regiono aplinkos oro temperatūros, kritulių duomenys. I meteorologę duomenų laikmeną įvesta vidutinè dienos temperatūra ir kritulių kiekis. Taip pat galima pasirinkti ir kitus parametrus: tokius kaip minimali ir maksimali dienos temperatūra pridedant saulès radiacijos duomenis ir vejo greiti (5.2 pav.). Modeliuojant taip pat galima ịvesti papildomus duomenis apie krituliuose esanti azoto kieki.

Modelis vertina tik esamų metų anglies pokyčius ir anglies dioksido emisiją iš dirvožemio. Tam tikslui buvo sukurtos meteorologès laikmenos, kuriuose at- 
sižvelgiant ị meteorologinę prognozę pagal UTBalt7. Priimta, kad aplinkos vidutinè metinè oro temperatūra padidès $3{ }^{\circ} \mathrm{C}$ laipsniais, o vidutinis metinis kritulių kiekis $2,3 \%$.

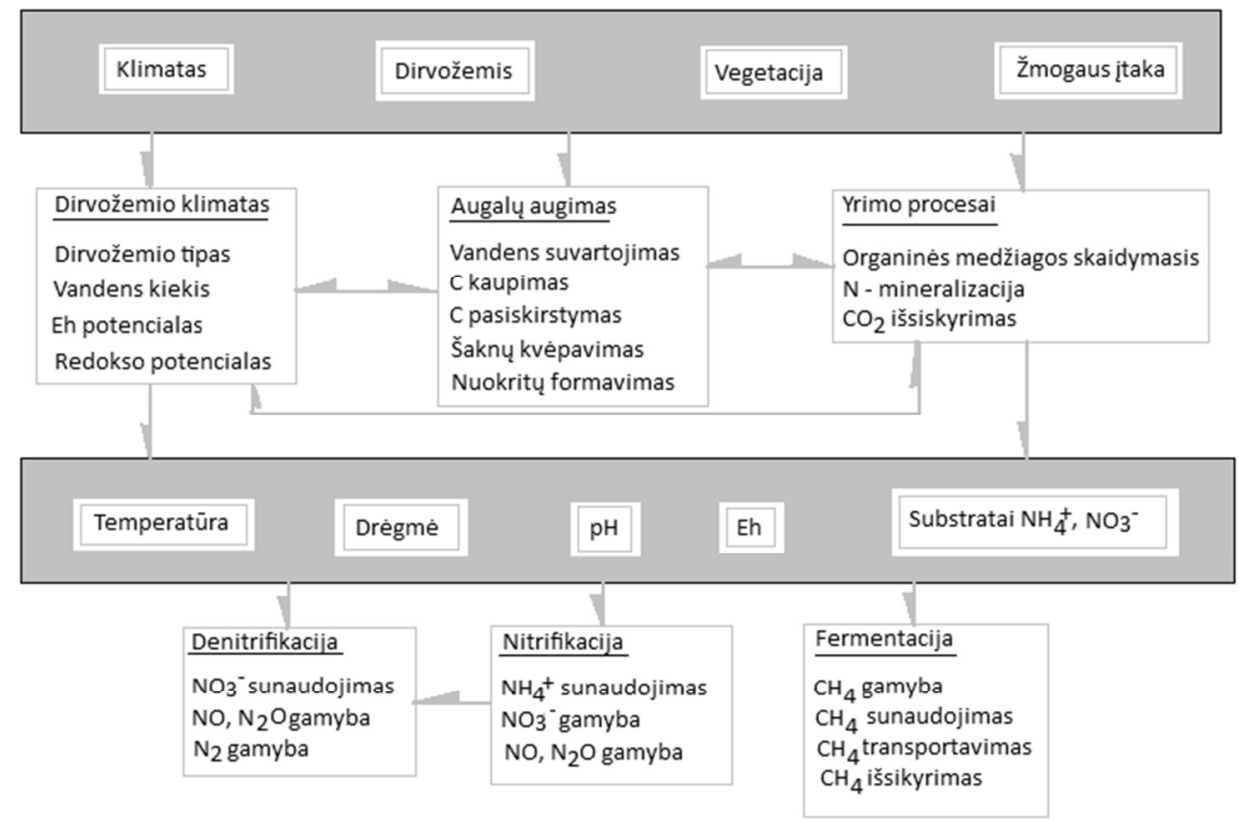

5.1 pav. DNDC modelio procesų modeliavimo vidinė struktūra (DNDC... 2010)

Fig. 5.1. DNDC model for modeling the internal structure (DNDC... 2010)

Antras komponentas sudarytas iš nitrifikacijos, denitrifikacijos modeliu, prognozuoja išmetamo anglies dioksido $\left(\mathrm{CO}_{2}\right)$, metano $\left(\mathrm{CH}_{4}\right)$, amoniako $\left(\mathrm{NH}_{3}\right)$, azoto oksidas (NO), azoto suboksido $\left(\mathrm{N}_{2} \mathrm{O}\right)$ ir diazoto $\left(\mathrm{N}_{2}\right)$ dujų kiekius išsiskiriančius iš žemès ūkio dirvožemių (5.1 pav.). Be dirvožemio organinès anglies analizuojami ir kiti anglies šaltiniai: augalų liekanos (pvz., kraikas), mikrobu biomasè, humatai (t. y. veikliosios humuso rūgštys) ir pasyvus humusas. Analizès metu atsižvelgiama ị kiekvieno anglies šaltinio skilimo greičius, bei i molio ir azoto kiekị dirvožemyje. Taip pat atsižvelgiama i dirvožemio temperatūra, drègmę. Modelis įvertina dirvožemyje esančios anglies oksidacinius ir išplovimo procesus. C:N santykio modeliavimas antrosios dalies etape nusako vadinamaji mažosios biologinès medžiagų apykaitos ratą, kuriame mikroorganizmai skaido augalų ir gyvūnų liekanas i paprastesnius organinius darinius ir mineralinius komponentus, kurie biologiškai sujungiami ir vèl patenka ị naują šios apykaitos 
ciklą. Mikroorganizmai naudoja anglies junginius energijai ir mitybai, o azotas yra būtinas DNR baltymų sintezei ir fermentams.

Pirmiausiai nurodomas dirvožemio tipas - smèlžemiai. Nurodomas nustatytas dirvožemio tankis iki $10 \mathrm{~cm}$ gylio. Konkrečiu atveju ariamo dirvožemio tankis buvo $-1,236 \mathrm{~g} / \mathrm{cm}^{3}$, miško dirvožemio tankis $1,198 \mathrm{~g} / \mathrm{cm}^{3}$, o pievos dirvožemio $1,425 \mathrm{~g} / \mathrm{cm}^{3}$. Ivedamas dirvožemio $\mathrm{pH}$ (ariamo dirvožemio buvo -6 , miško dirvožemio - 5,4 o pievos dirvožemio - 7,2). Pagal išanalizuotus bendrosios anglies kiekio duomenis vidutinè anglies koncentracija nuo 0 iki $10 \mathrm{~cm}$ ariamame dirvožemyje perskaičiuota iš procentinès dalies $\mathrm{i} \mathrm{kgC} / \mathrm{kg}$ dirvožemio buvo $0,022 \mathrm{kgC} / \mathrm{kg}$, o pievos dirvožemyje $0,019 \mathrm{kgC} / \mathrm{kg}$ ir miško dirvožemyje $0,027 \mathrm{kgC} / \mathrm{kg}$.

Modelyje tai pat galima įvesti išsiskyrusi vidutini metinį $\mathrm{CO}_{2}$ dujų kiekị.
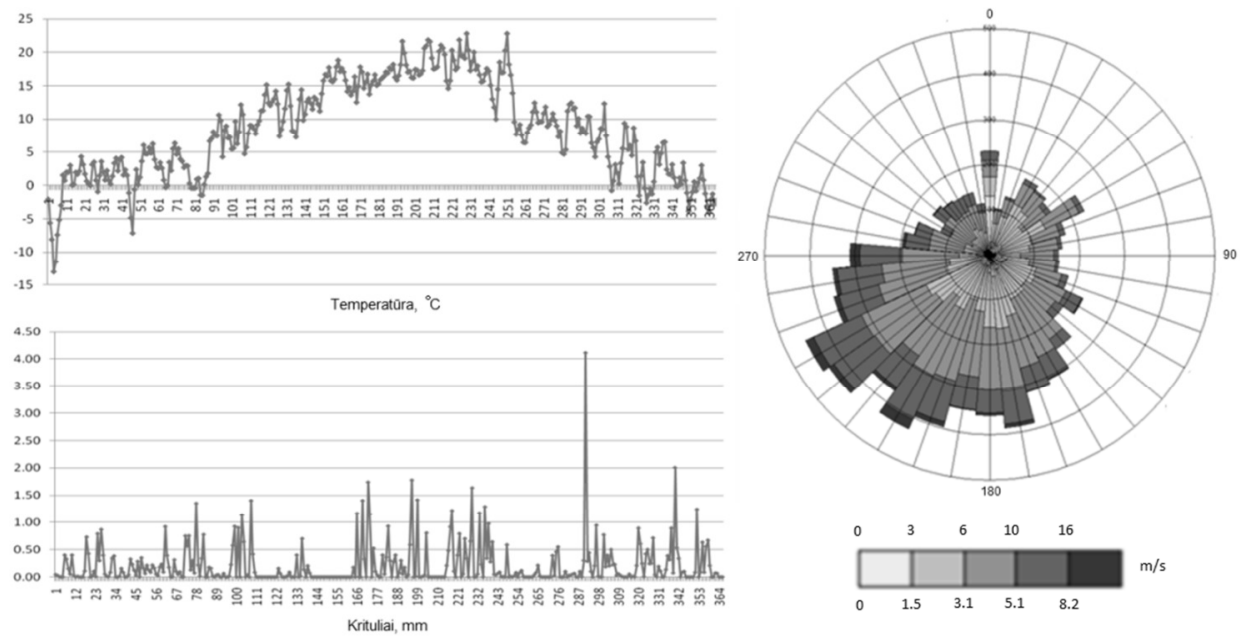

5.2 pav. Temperatūra, krituliai ir vejjo greičio, bei krypčiu pasikartotinumas Vilniaus regione 2009 metais

Fig. 5.2. Temperature, precipitation, wind speed and directions of the Vilnius region 2009 year

Modelis ịvertina skaidomos organinès anglies kitimą dirvožemyje. Vertindamas organinę angli modelis atsižvelgia $i$ jos transformavimą $i$ anglies dioksidą ir ištirpusią organinę angli, kuri susidaro kaip tarpinis organinès anglies skilimo produktas ir kuri iškarto sunaudojama mikroorganizmų. Mineralizuojantis organinei angliai ji yra dalinai verčiama i kitą organinių medžiagų grupę. Mineralizacijos metu aktyviai dalyvauja ir azotas. Modelis ivertina aerobines ir anaerobines sąlygas. Šių sąlygų metu modelis vertina dirvožemio aeracijos faktorių apskaičiuojant deguonies arba kitų oksidantų kieki dirvožemio profilyje. Anali- 
zuojama dirvožemio difuzijos matrica. Tai pat vertina fermentacijos procesus, kurių metu susidaro vandenilio sulfidas $\mathrm{H}_{2} \mathrm{~S}$ ir metanas $\mathrm{CH}_{4}$, kurie mažina dirvožemio Eh.

DNDC modelis leidžia tiksliai ịvertinti augalų augimą. Nuo augalų augimo priklauso dirvožemyje esančio vandens kiekis ir azoto kaitos režimas. Modelis puikiai imituoja pasèlių auginimą. Ivertina didžiausią derlių, azoto poreiki dirvožemyje. Modeliavimo metu ịvertinama fotosintezè, dirvožemio kvėpavimo, anglies pasiskirstymo dirvožemyje kaita, vandens ir azoto įsisavinimas. Po derliaus nuemimo modelis įvertina susidariusią šaknų biomasę dirvožemio profilyje, kitas antžemines augalų liekanas, kurios vèliau yra skaidomos ir mineralizuojamos mikroorganizmų.

\subsection{Bendrosios anglies kiekio kitimo ir anglies dioksido emisiju modeliavimo duomenys ir analizè}

Ariamas dirvožemis. Ariamajame dirvožemyje modeliavimo laikotarpis apėmè dešimties metų laikotarpi. Pateikti pirmujų ir po dešimties metų laikotarpio duomenys.

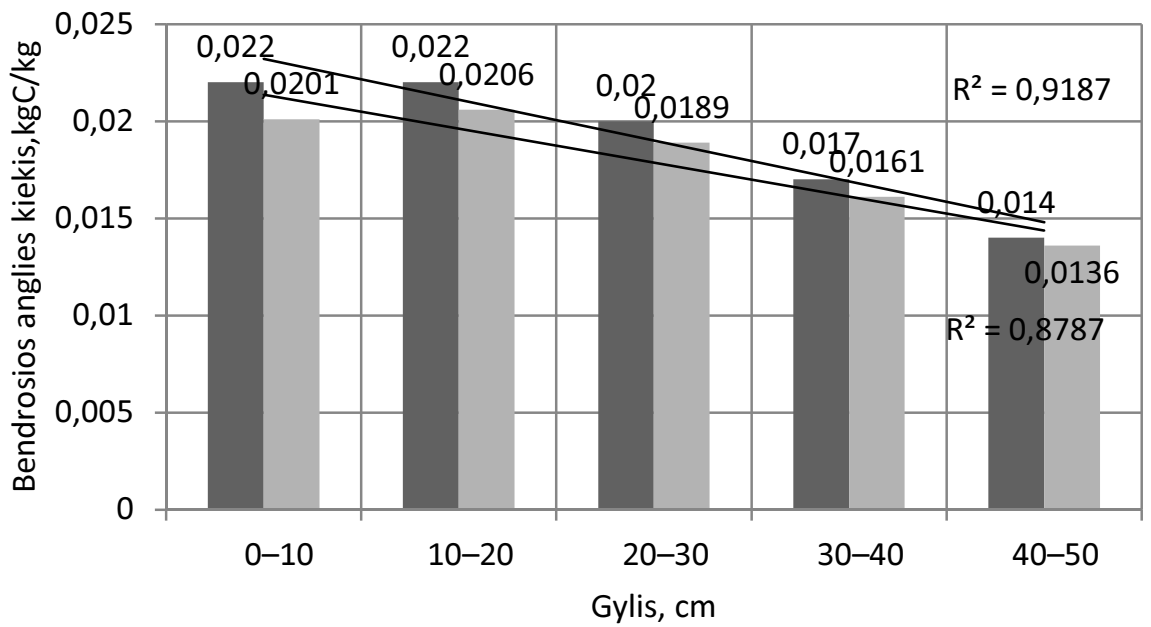

Po 1 mety

Po 10 metų

5.3 pav. Bendrosios anglies kiekio pokytis po 10 metu ariamame dirvožemyje gylyje nuo 0 iki $50 \mathrm{~cm}$

Fig. 5.3. Total carbon change after 10 years of arable soil depths ranging from 0 to $50 \mathrm{~cm}$ 
Atlikus modeliavimą pirmujų metų anglies kiekiuose nustatyta, kad bendrosios anglies kiekis $0-10 \mathrm{~cm}$ gylyje sumažès $8,22 \%$ t. y. 1,1 karto (5.3 pav.). Gyliuose nuo 10 iki $50 \mathrm{~cm}$ bendrosios anglies kiekis dirvožemyje sumažès vidutiniškai po $5,57 \%$ kas $10 \mathrm{~cm}$. Lyginant su tyrimo rezultatais gautos vertès po dešimties metų turètų sumažèti iki 1,12 karto arba procentais - 10,7\%. Nesutapimas tarp tyrimo duomenų ir duomenų pateiktų modelio, esant pirmiesiems metams yra 2,7\%. Bendrosios anglies kiekis 1 hektare ariamo dirvožemio per pirmus metus sumažèja nuo $87394 \mathrm{kgC} /$ ha iki $86564 \mathrm{kgC} / \mathrm{ha}$ t. y. $830 \mathrm{kgC} / \mathrm{ha}$ (5.4 pav.). Po dešimties metų šiame dirvožemyje bendrosios anglies metinis kiekis sieks nuo $82339 \mathrm{kgC} / \mathrm{ha}$ iki $81887 \mathrm{kgC} / \mathrm{ha}$ (metinis skirtumas $452 \mathrm{kgC} / \mathrm{ha}$ ). Po dešimties metų ariamajame dirvožemyje bendrosios anglies sumažès nuo 830 iki $452 \mathrm{kgC} / \mathrm{ha} \mathrm{t.} \mathrm{y.} 378 \mathrm{kgC} / \mathrm{ha}$.

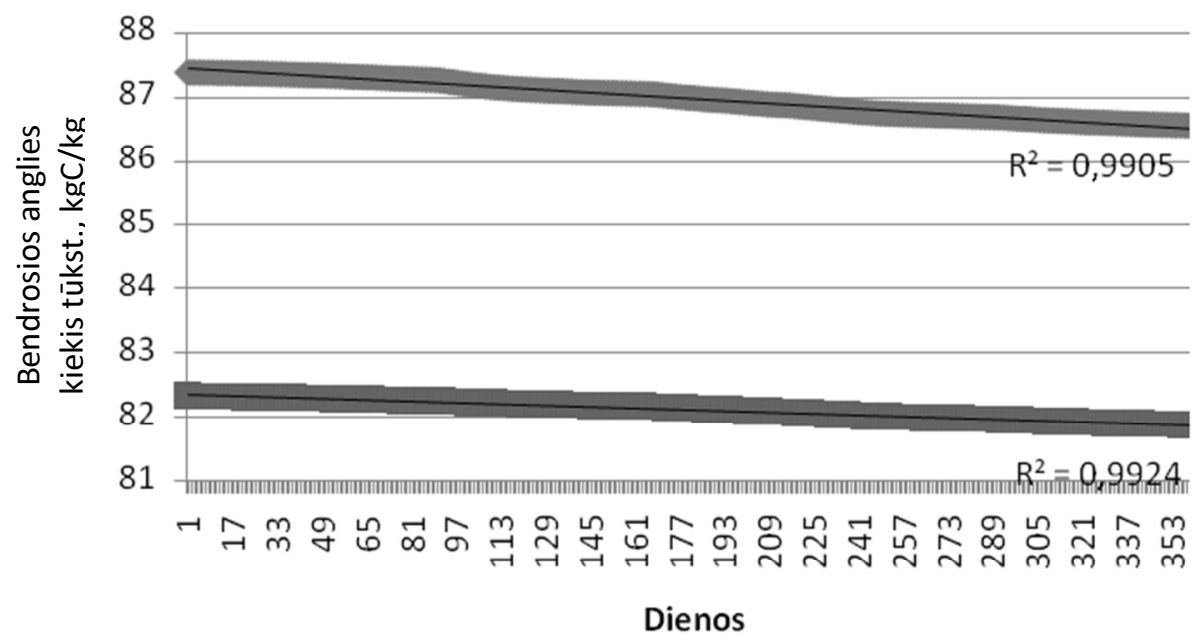

- Po1 mety - Po10 mety

5.4 pav. Bendrosios anglies kiekio pokytis po 10 metų ariamame dirvožemyje

Fig. 5.4. Total carbon change after 10 years of arable soil

Anglies dioksido vidutinès emisijos iš ariamo dirvožemio pirmaisiais metais per parą iš hektaro išsiskyre $2,28 \mathrm{kgCO}_{2} /$ ha per parą. Didžiausios emisijos per parą nustatytos prasidejus pavasariui $-6,84 \mathrm{kgCO}_{2} / \mathrm{ha}$. Vegetaciniu periodu anglies dioksido emisijos siekè iki $4,89 \mathrm{kgCO}_{2} /$ ha per parą. Anglies dioksido emisijų kitimą tuo metu labai įtakojo kritulių kiekis (5.5 pav.).

Mineralizacijos procesams palaikyti būtina drègmè. Dirvožemio drègniui sumažejus, sumažeja ir mikrobiologinis aktyvumas. Rudeni padidejjus drègmès 
kiekiui dirvožemyje anglies dioksido emisijos taipogi padidèja. Atlikus koreliacinę analizę nustatyta, kad kritulių kiekis ir anglies dioksido emisijos koreliacijos koeficientas siekè 0,3 .

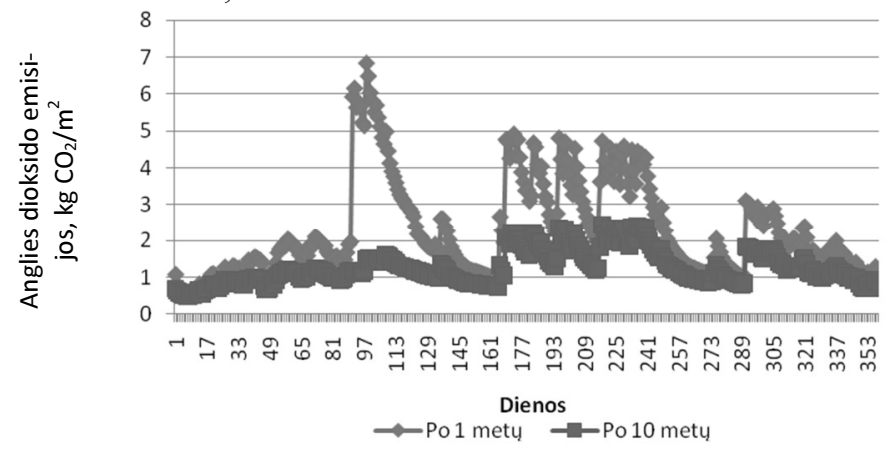

5.5 pav. Anglies dioksido emisijų pokytis per parą po 10 metų ariamame dirvožemyje

Fig. 5.5. Carbon dioxide emissions per day change after 10 years of arable soil

Vidutinė anglies dioksido emisija po dešimties metų sieke $1,24 \mathrm{kgCO}_{2} /$ ha. Mažejjantis bendrosios anglies kiekis paskatino ir mažesnius anglies dioksido emisiju kiekius. Anglies dioksido priklausomybe nuo kritulių kiekio išliko ta pati. Koreliacijos koeficientas siekè - 0,35 (5.6 pav.). Patikimiausiai anglies dioksido emisijos koreliuoja, esant išmetimams $0,5-2 \mathrm{kgCO}_{2} /$ ha per parą. Temperatūros atžvilgiu anglies dioksido emisijos koreliacijos koeficientas sieké 0,51 .

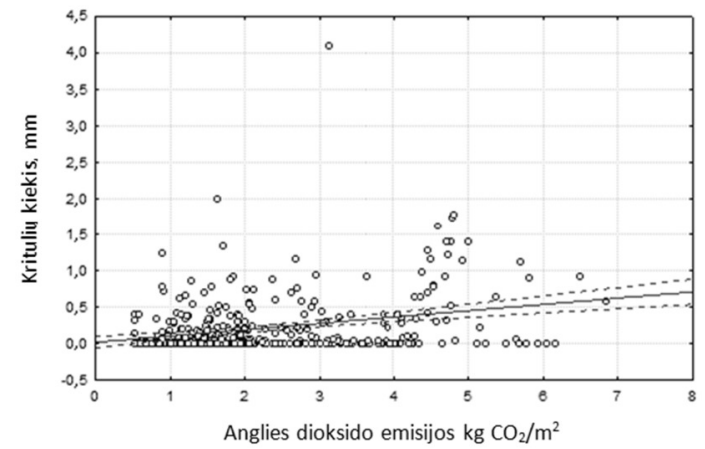

5.6 pav. Anglies dioksido emisijų priklausomybė nuo kritulių kiekio ariamame dirvožemyje, esant pirmiesiems modeliavimo metams

Fig. 5.6. Carbon dioxide emissions dependence on rainfall arable soil in the first year of modeling 


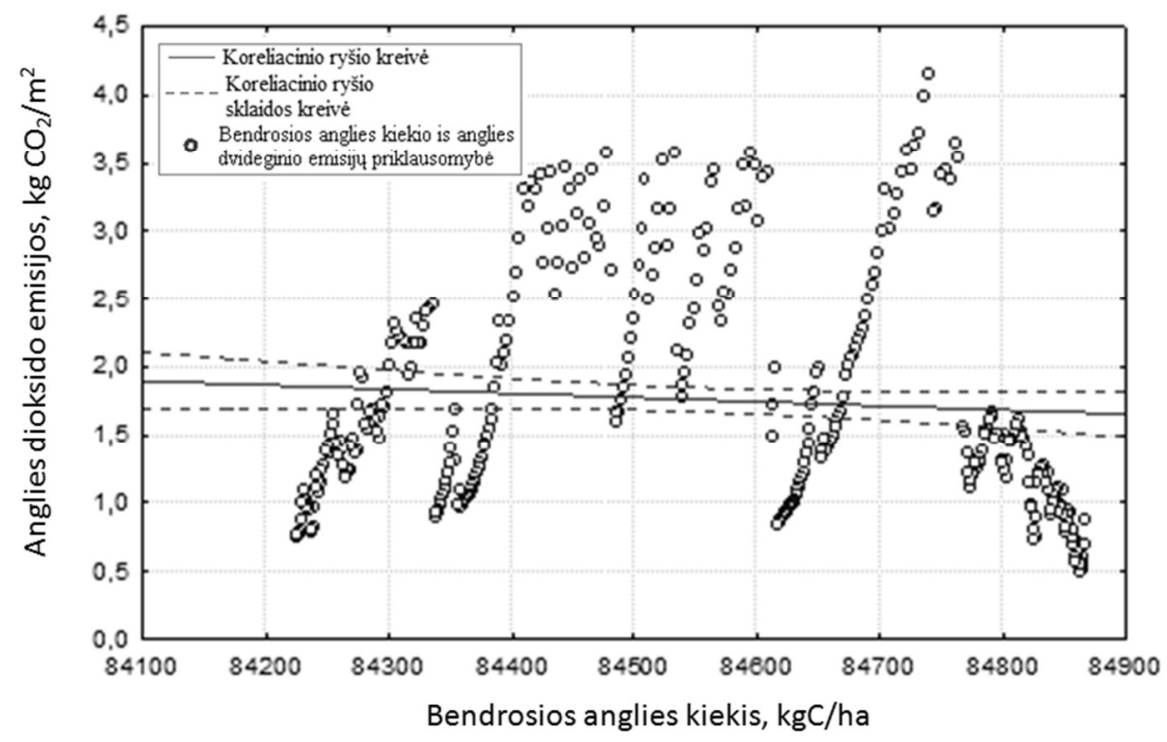

5.7 pav. Bendrosios anglies kiekio priklausomybè nuo anglies dioksido emisijų ariamame dirvožemyje

Fig. 5.7. Total carbon dependence on carbon dioxide emissions of arable soils

Modeliuojant taip pat buvo įvertintas ryšys tarp bendrosios anglies kiekio dirvožemyje ir anglies dioksido emisijų. Ariamajame dirvožemyje tarp duomenų nustatytas atvirkštinè koreliacija $\mathrm{r}=-0,74$ (5.7 pav.). Statistinei analizei buvo imtos vidutinès bendrosios ir anglies dioksido reikšmès dešimties metų laikotarpyje. Taip pat, nustatyta, kad ryšys yra tendencingas. Grafike nuo $8429 \mathrm{kgC} / \mathrm{ha}$ iki $84347 \mathrm{kgC} / \mathrm{ha}$, nuo $84347 \mathrm{kgC} / \mathrm{ha}$ iki $84618 \mathrm{kgC} / \mathrm{ha}$ ir nuo $84618 \mathrm{kgC} / \mathrm{ha}$ iki $84883 \mathrm{kgC} / \mathrm{ha}$ nustatyti tendencingi ryšio išsibarstymai. Esant daugiausiai anglies dirvožemyje išsiskyrè maksimalios emisijos anglies dioksido, kas atitinką pavasario metu vykstančius mineralizacijos procesus. Kol aplinkos oro temperatūra nèra didelè anglies dioksido emisijos kyla plaipsniui, bet vèliau dèl klimatinių rodiklių itakos anglies dioksido emisijos pradeda mažèti. Vidurinè dalis grafiko atspindi vegetaciniu periodu vykstančius apykaitos procesus. Ir metų pabaigoje silpnejjanti medžiagų apykaita dirvožemyje atsispindi kai anglies kiekiams mažejant mažèjo ir anglies dioksido emisijos.

Klimato kaitos atžvilgiu ariamajame dirvožemyje bendrosios anglies kiekis nežymiai padidejjo. $0-10 \mathrm{~cm}$ gylyje dèl padidejusios aplinkos oro temperatūros ir krituliu kiekio bendrosios anglies kiekis padidejo $0,9 \%$, esant pirmiesiems metams. Po 10 metu šis padidejimas $0-10 \mathrm{~cm}$ gylyje sieks 6,1\% (5.8 pav.). Dèl pasislenkančių klimatinių juostų Lietuvos teritorijoje žvelgiant į šias prognozes turi 
padidèti biomasès prieaugis. Modelis ịvertino padidejusios vidutinès metinès temperatūros įtaka, o taip pat îvertino ir kritulių kiekio pokyti. Tačiau šis modelis nevertina neigiamų klimatinių sąlygų, tokių kaip potvyniai ir užsitęsusios sausros padarinių.

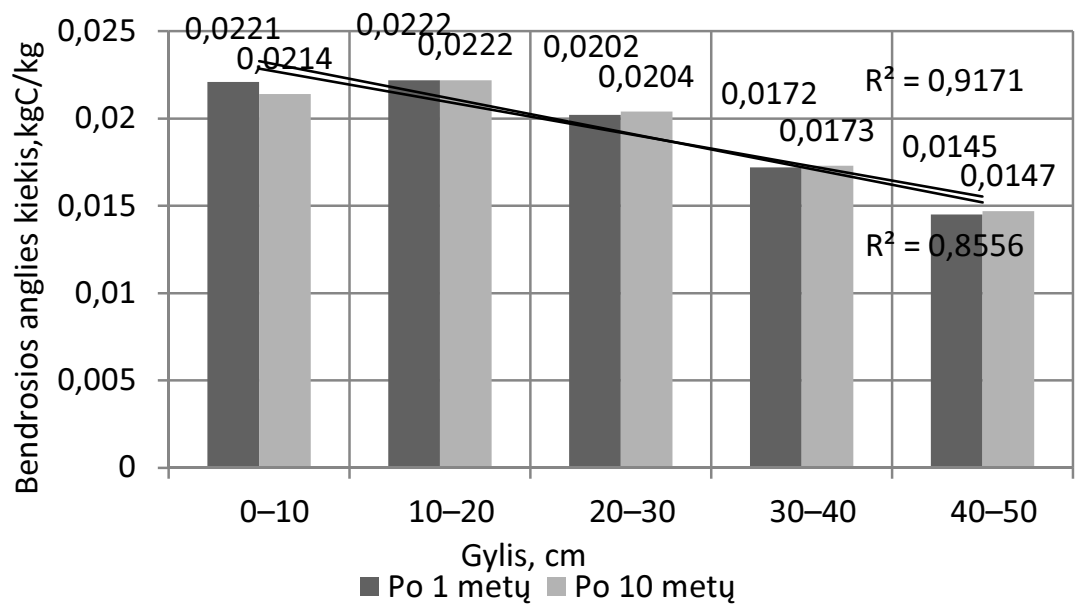

5.8 pav. Bendrosios anglies kiekio pokytis po 10 metų ariamame dirvožemyje gylyje nuo 0 iki $50 \mathrm{~cm}$, ivertinus klimato itaką

Fig. 5.8. Total carbon change after 10 years of arable soil depths ranging from 0 to $50 \mathrm{~cm}$, the assessment of climate change

Kituose gyliuose bendrosios anglies kiekis pirmaisiais metais padidejo vidutiniškai $1 \%$. Po dešimties metu gauti duomenys parodè, kad bendrosios anglies kiekis gyliuose nuo 10 iki $50 \mathrm{~cm}$ turètų padidèti vidutiniškai 7,2\% (5.9 pav.). Kaip matome klimato kaitos itaką ariamam dirvožemiui nurode didejjanti bendrosios anglies kiekị. Tačiau, daroma prielaida, kad arčiau pusiaujo esantys dirvožemiai patirs bendrosios anglies kiekio mažejimą, dèl mažèjančio kritulių kiekio pusiaujo klimatinèse zonose.

Anglies dioksido emisijos ariamajame dirvožemyje pagal sumodeliuotus duomenis esamoje padètyje po 10 metų naudojimo sumažèja 379 $\mathrm{kgCO}_{2} / \mathrm{ha} /$ metus. Mažèjimo priežastimis yra nualintas dirvožemis, kuriame bendrosios anglies per 10 naudojimo metų sumažejo $378 \mathrm{kgC} / \mathrm{ha}$. Prognozuojamoje padètyje anglies dioksido emisijos dèl palankių klimatinių sąlygų augalams augti padidès per antrus metus iki $57 \mathrm{kgCO}_{2} / \mathrm{ha} /$ metus. Tačiau, jau nuo 3 metų naudojimo anglies dioksido emisijos mažès. 


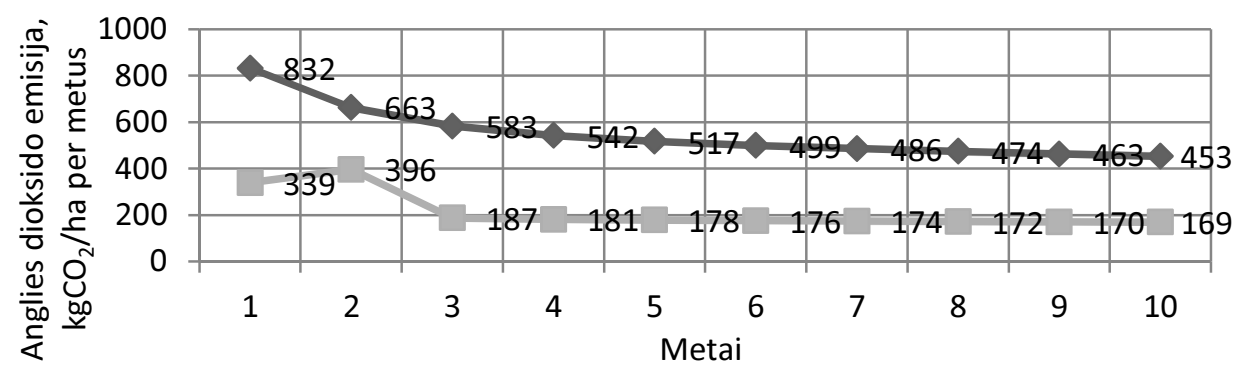

$\neg$ Esama situacija, $\mathrm{kg} \mathrm{CO}_{2} /$ ha per metus

- - Prognozuojama situacija, $\mathrm{kg} \mathrm{CO}_{2}$ /ha per metus

5.9 pav. Anglies dioksido emisijų pokytis ariamame dirvožemyje po 10 metu, ivertinus klimato kaita

Fig. 5.9. Carbon dioxide emissions from arable soils change after 10 years, the assessment of climate change

Pievos dirvožemis. Pievos dirvožemyje sumodeliuoti bendrosios anglies kiekiai palyginti, su išmatuotas natūriniais tyrimai, buvo $-1,6 \%$ mažesni $(0-10$ $\mathrm{cm}$ gylis) (5.10 pav.). Nustatyta, kad per pirmus metus bendrosios anglies kiekis pievos dirvožemio profilyje $(0-50 \mathrm{~cm})$ sumažès 1,1 kartą. Po dešimties metų pievos dirvožemyje bendrosios anglies $0-10 \mathrm{~cm}$ gylyje sumažès iki 7,94\% arba 1,1 karto. Gyliuose nuo 10 iki $50 \mathrm{~cm}$ bendrosios anglies sumažejimas sieks $5,34 \%$. Vidutiniškai lyginant pirmus ir dešimtus metus visuose gyliuose bendrosios anglies kiekis sumažeja iki 1,1 karto. Palyginus dešimtujų modeliavimo duomenis su tyrimais nustatyta reikšme gauta, kad skirtumas bus lygus $9,4 \%$.

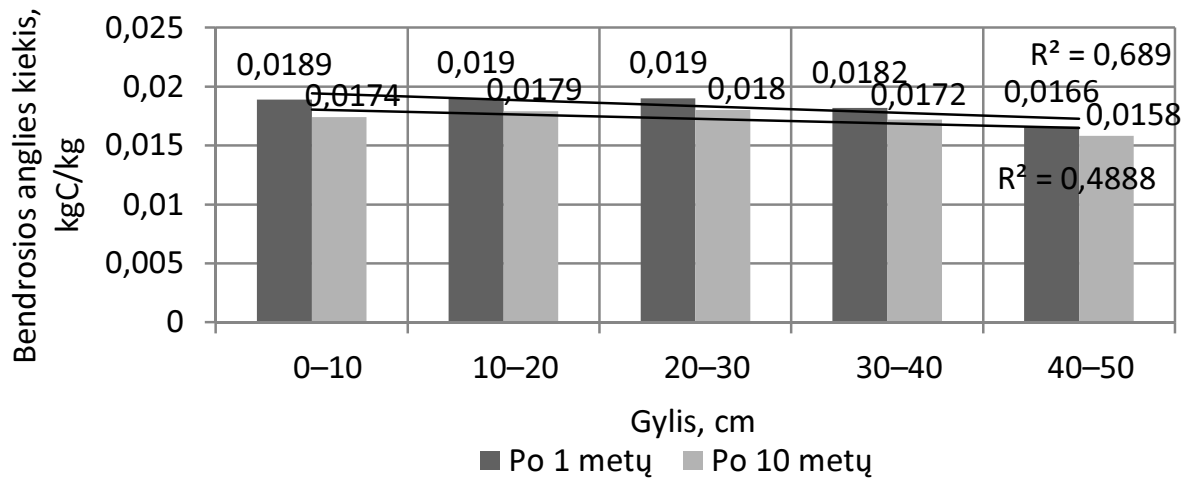

5.10 pav. Bendrosios anglies kiekio pokytis po 10 metų pievos dirvožemyje gylyje nuo 0 iki $50 \mathrm{~cm}$

Fig. 5.10. Total carbon change after 10 years of grassland soil depths ranging from 0 to $50 \mathrm{~cm}$ 
Pievos dirvožemiuose per pirmuosius metus vieno hektaro plote bendrosios anglies mažès iki $740 \mathrm{kgC} / \mathrm{ha}$ (5.11 pav.). Tuo tarpu dešimtaisiai metais šis sumažejjimo kiekis pasieks $542 \mathrm{kgC} / \mathrm{ha}$. Taigi per dešimti metu bendrosios anglies turètų sumažèti iki $198 \mathrm{kgC} / \mathrm{ha}$.

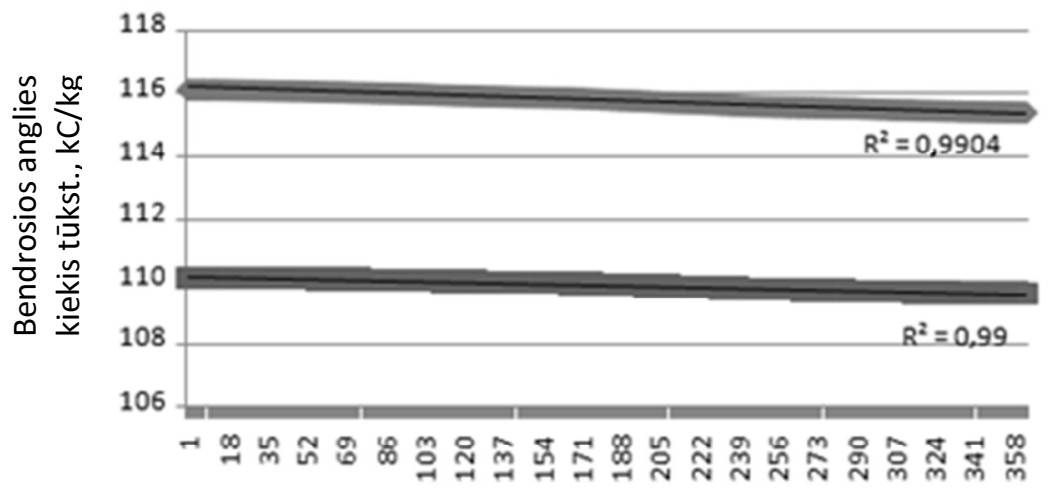

Dienos

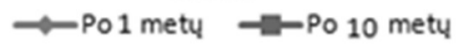

5.11 pav. Bendrosios anglies kiekio pokytis po 10 metų pievos dirvožemyje

Fig. 5.11. Total carbon change after 10 years of grassland soil

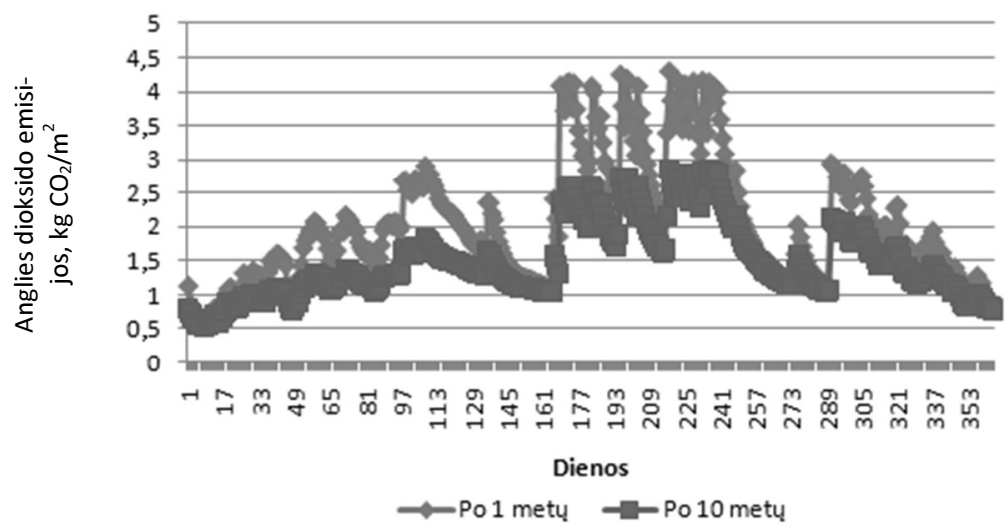

5.12 pav. Anglies dioksido emisijų pokytis per parą po 10 metų pievos dirvožemyje

Fig. 5.12. Carbon dioxide emissions per day change after 10 years of grassland soil 


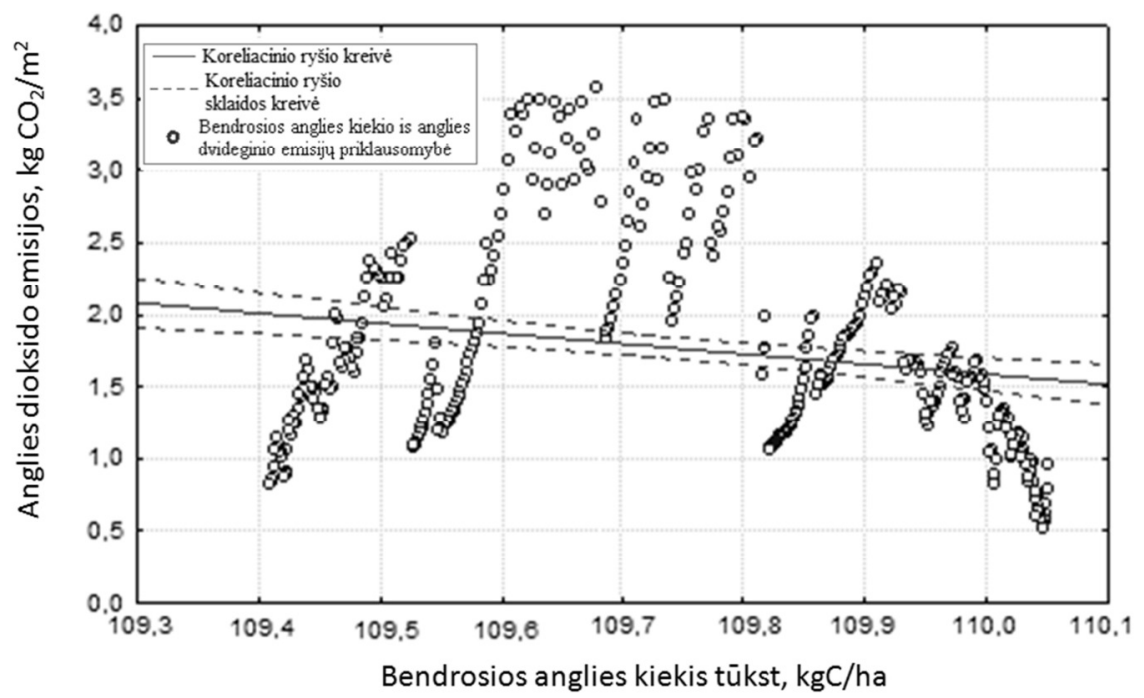

5.13 pav. Bendrosios anglies kiekio priklausomybè nuo anglies dioksido emisijų pievos dirvožemyje

Fig. 5.13. Total carbon dependence on carbon dioxide emissions of grassland soils

Pagal koreliacinius ryšius bendrosios anglies kiekiai ir anglies dioksido emisijos pievos dirvožemyje yra tapatūs ariamajam dirvožemiui. Šiame dirvožemyje taip pat išskiriami panašūs koreliacinių ryšiu išsidèstymas. Kaip ir ariamajame dirvožemyje pievos dirvožemio anglies dioksido emisijos pradeda didèti tik pavasario sezonu. Tačiau, pievos dirvožemis i aplinkos orą išmeta daugiau anglies dioksido (ariamas - 1,24 $\mathrm{kgCO}_{2} / \mathrm{ha}$, pievos - 1,53 $\mathrm{kgCO}_{2} / \mathrm{ha}$ ) (5.13 pav.). Daugiausiai anglies dioksido pavasari buvo išmesta iki $2,4 \mathrm{kgCO}_{2} / \mathrm{m}^{2}$. Vegetaciniu periodu anglies dioksido emisijos siekè iki $3,51 \mathrm{kgCO}_{2} /$ ha. Tuo tarpu metu pabaigoje šios emisijos sumažejo iki $2,51 \mathrm{kgCO}_{2} /$ ha (5.12 pav.). Palyginus su ariamu dirvožemiu anglies dioksido emisijos vegetaciniu ir rudens laikotarpiu buvo panašios. Labiausiai ariamasis dirvožemis išsiskyre pavasari. Tokiam pokyčiui didelès įtakos turi ariamo lauko pavasariniai žemès darbai.

Klimato kaitos poveikis pievos dirvožemiui itakos turèjo gilesniuose sluoksniuose. Šiuose sluoksniuose (10-30 cm gylis) nustatytas bendrosios anglies padidejjimas (5.14 pav.). Jei per pirmuosius metus bendrosios anglies pievos dirvožemyje $0-10 \mathrm{~cm}$ gylyje siekè $0,019 \mathrm{kgC} / \mathrm{kg}$, tai dešimtaisiais metais jis sumažejo iki 1,01 karto. Tačiau pirmaisiais analizès metais bendrosios anglies kiekis gilesniuose sluoksniuose padidejo labai mažai. Tuo tarpu dešimtujų metų duomenys 10-30 cm gylyje padidejjo iki 1,1 karto. Lyginant gautus duomenis 0$10 \mathrm{~cm}$ gylyje su išmatuotais tyrimo metu nustatyta, kad jie padidejo $1 \%$. Dešim- 
tujų metų analizės duomenimis, modelio ir natūrinių tyrimų rezultatai sutapo. Pagal gylius nustatyta, kad vidutinis bendrosios anglies kiekis pirmujuc metu duomenyse siekè $0,018 \mathrm{kgC} / \mathrm{kg}$. Sulyginus su dešimtaisiais metais skirtumas buvo didesnis $2,81 \%$.

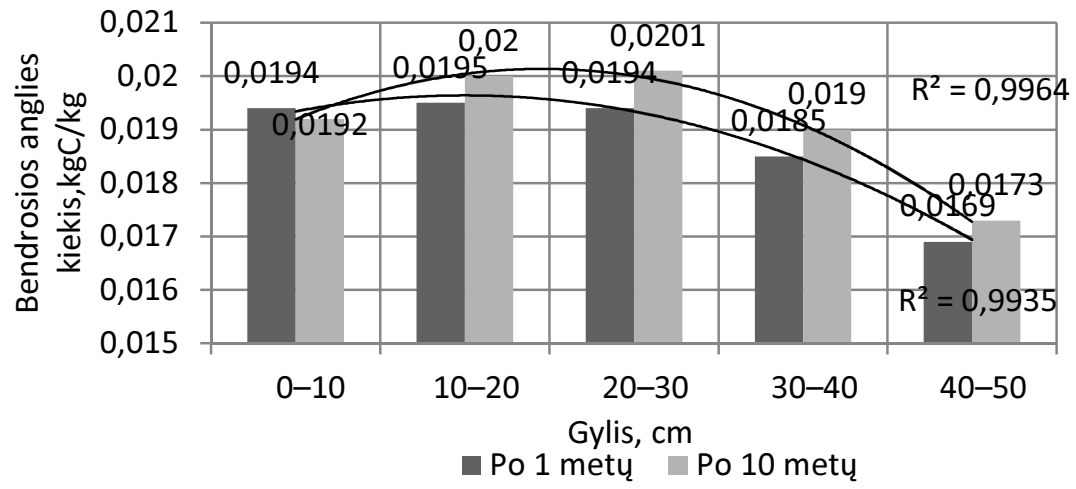

5.14 pav. Bendrosios anglies kiekio pokytis po 10 metu pievos dirvožemyje gylyje nuo 0 iki $50 \mathrm{~cm}$, ivertinus klimato itaką

Fig. 5.14. Total carbon change after 10 years of grassland soil depths ranging from 0 to $50 \mathrm{~cm}$, the assessment of climate change

Anglies dioksido emisijos esamoje padètyje didejja tik iki antrujų metų iki 1,2 karto ( $159 \mathrm{kgCO}_{2} / \mathrm{ha} /$ metus) (5.15 pav.). Vèlesniuose laikotarpiuose anglies dioksido emisjos mažèjo. Lygiant su esamos padèties pirmaisiais metais, anglies dioksido emisijos sumažès iki $200 \mathrm{kgCO}_{2} / \mathrm{ha} /$ metus. Tačiau pievos dirvožemio prognozuojamoje padètyje anglies dioksido emisijos didès. Ryškiausias padidèjimas bus per pirmus keturis metus $-443 \mathrm{kgCO}_{2} / \mathrm{ha} /$ metus. Tuo tarpu vèlesniais metais padidejimas stabilizuosis.

Jei ariamajame dirvožemyje anglies dioksido emisijos ir bendrosios anglies kiekis mažès, tai pievos dirvožemyje vyks priešingai. Taip yra todèl, kad ariamas dirvožemis yra alinamas kai tuo tarpu pievos dirvožemio modeliavimo sąlygos buvo pritaikytos nenaudojamai pievai. Galima daryti prielaida, kad nenaudojamos žemès plotai vešès, kadangi bus palankesnès augimo sąlygos. I dirvožemi pateks daugiau susidariusios biomasès, o tai paskatins bendrosios anglies augimą gilesniuose sluoksniuose ir anglies dioksido emisijas. 


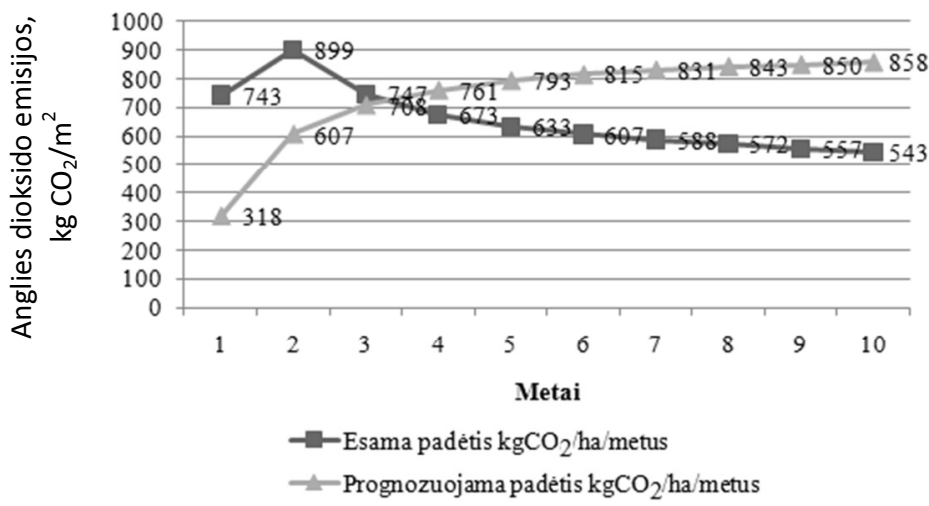

5.15 pav. Anglies dioksido emisjų pokytis pievos dirvožemyje po 10 metų, ivertinus klimato kaita

Fig. 5.15. Carbon dioxide emissions from grassland soils change after 10 years, the assessment of climate change

Miško dirvožemis. Bendrosios anglies kiekiai miško dirvožemyje taip pat kaip ir pievos dirvožemyje padidès gilesniuose dirvožemio sluoksniuose. Sis padidejimas geriausiai turi atsispindèti po dešimties metų. Pirmaisiais metasi bendrosios anglies kiekis tik labai nežymiai padidès $10-30 \mathrm{~cm}$ gyliuose. Tuo tarpu dešimtaisiais metais bendrosios anglies kiekis pievos dirvožemyje lyginant su 0-10 cm gylio duomenimis padidès iki 1,05 kartų arba iki 4,04\% (5.16 pav.). Natūrinių tyrimų duomenimis pirmaisiais metais $0-10 \mathrm{~cm}$ gylio duomenys yra $0,4 \%$ didesni, o dešimtaisiais metais $0,4 \%$ mažesni.

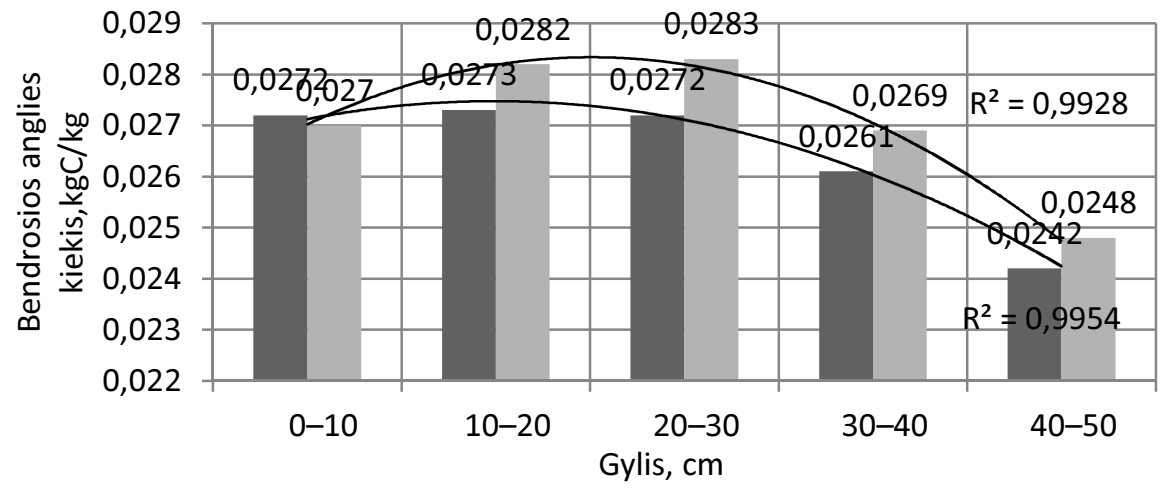

- Po 1 metu $\square$ Po 10 metų

5.16 pav. Bendrosios anglies kiekio pokytis po 10 metų miško dirvožemyje gylyje nuo 0 iki $50 \mathrm{~cm}$

Fig. 5.16. Total carbon change after 10 years of forest soil depths ranging from 0 to $50 \mathrm{~cm}$ 
Bendrosios anglies kiekiai miško dirvožemyje esamoje padètyje linkę kauptis metu pabaigoje. Žvelgiant i grafiką matyti, kad nuo lapkričio mènesio bendrosios anglies kiekis dirvožemyje padideja $812 \mathrm{kgC} / \mathrm{ha}$ po 1 metų, o po 10 metu šis padidejjimas siekia iki $4623 \mathrm{kgC} / \mathrm{ha} \mathrm{(5.17} \mathrm{pav.).} \mathrm{Tačiau} \mathrm{metinis} \mathrm{balansas} \mathrm{rodo,}$ kad bendrosios anglies kiekis miško dirvožemyje per pirmus metus padidès 937 $\mathrm{kgC} / \mathrm{ha}$, o po dešimties metu $565 \mathrm{kgC} / \mathrm{ha}$ kasmet. Bet po dešimties metų miško dirvožemyje bus vidutiniškai $144447 \mathrm{kgC} / \mathrm{ha}$, kai pirmaisiais metais buvo $140955 \mathrm{kgC} / \mathrm{ha}$. Po dešimties metų bendrosios anglies miško dirvožemyje turi padidèti iki $4058 \mathrm{kgC} / \mathrm{ha}$.

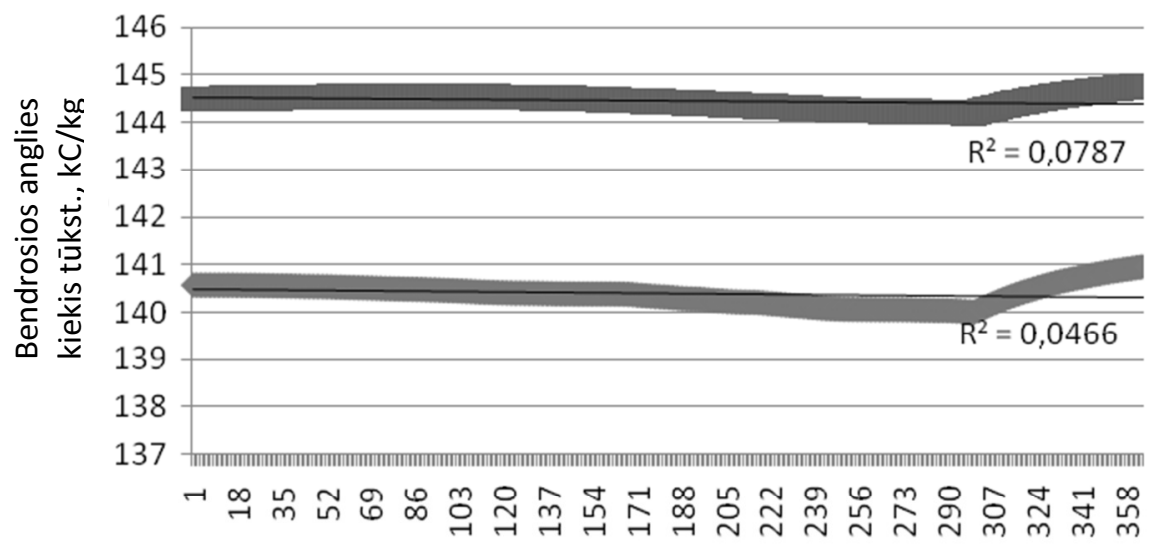

Dienos

\section{$\leadsto$ Po1 mety $\rightarrow$ Po 10 metu}

5.17 pav. Bendrosios anglies kiekio pokytis po 10 metų miško dirvožemyje

Fig. 5.17. Total carbon change after 10 years of forest soil

Vidutiniškai per pirmus metus miško dirvožemyje bus išmetama iki 2,82 $\mathrm{kgCO}_{2} /$ ha per parą. Dešimtujų metu laikotarpiu anglies dioksido emisijos sumažès iki $2,58 \mathrm{kgCO}_{2} / \mathrm{ha}$ per parą (5.18 pav.). Grafike matyti, kad pirmaisiais metais anglies dioksido emisijos buvo labai itakotos aplinkos parametrų. Dešimtaisiais metais anglies dioksido emisijos kito tolygiau. Didžiausia modeliavimo būdu nustatyta anglies dioksido emisija per pirmus metus sieke $6,52 \mathrm{kgCO}_{2} /$ ha per para, o po dešimties metų pievos dirvožemyje emisijos sumažèjo 4,71 $\mathrm{kgCO}_{2} /$ ha per parą. 


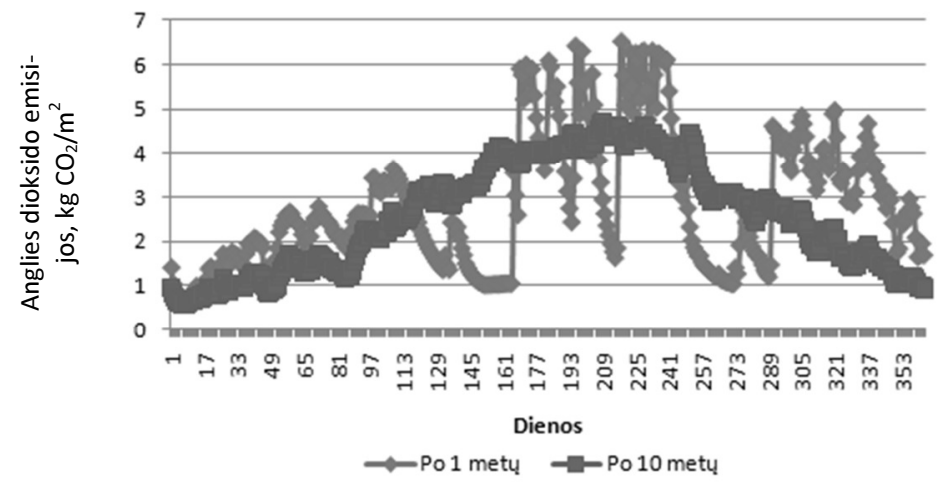

5.18 pav. Anglies dioksido emisijų pokytis per parą po 10 metų miško dirvožemyje

Fig. 5.18. Carbon dioxide emissions per day change after 10 years of forest soil

Išanalizavus kaip bendrosios anglies kiekis priklausomas nuo anglies dioksido emisijos nustatyta, kad r=-0,58 (5.19 pav.). Anglies dioksido emisijos metu pradžioje yra ganètinai mažos. Ariamajame dirvožemyje nustatytas anglies dioksido emisijos sieké iki $1,7 \mathrm{kgCO}_{2}$ /ha per para, o pievos dirvožemyje 1,65 $\mathrm{kgCO}_{2} /$ ha per parą. Vegetaciniu periodu anglies dioksido emisijos buvo miško dirvožemyje kito nuo $0,48 \mathrm{kgCO}_{2} /$ ha per parą iki $5,08 \mathrm{kgCO}_{2} /$ ha per para.

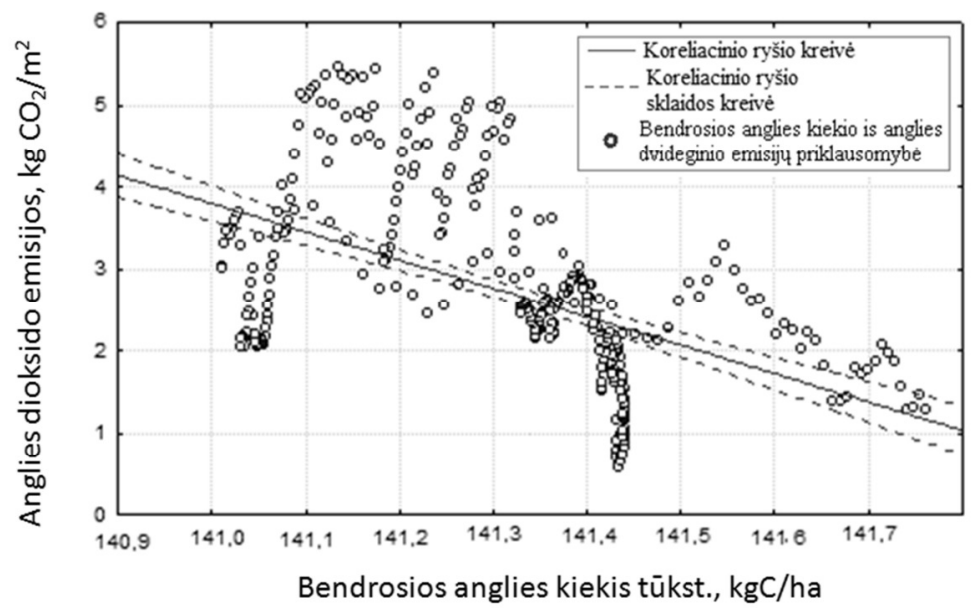

5.19 pav. Bendrosios anglies kiekio priklausomybé nuo anglies dioksido emisijų miško dirvožemyje

Fig. 5.19. Common dependence on carbon dioxide emissions of carbon in forest soils 
Bendrosios anglies kiekis miško dirvožemyje pirmaisiais metais imituojant klimato kaitą iki $30 \mathrm{~cm}$ gylio kito mažai. Lyginant gautus natūriniais tyrimais duomenis nustatyta, kad skirtumas su modeliavimo gautomis reikšmėmis yra lygus $0,7 \%$. Duomenys po dešimties metu gylyje $0-10 \mathrm{~cm}$ skiriasi iki $6,6 \% \mathrm{su}$ tyrimo duomenimis (5.20 pav.). Miško dirvožemyje nustatyta, kad bendrosios anglies kiekis po dešimties metų iki $30 \mathrm{~cm}$ didès (iki 1,04 karto). Tačiau prognozuojami kiekiai bus mažesni nei pirmaisiais metais. Žvelgiant i esamos situacijos bendrosios anglies kitimo grafiką matome, kad anglies kiekiai yra nežymiai didesni. Vidutinis bendrosios anglies kiekio sumažéjimas po dešimties metų bus lygus siekia $2,09 \%(10-50 \mathrm{~cm}$ gylis $)$.

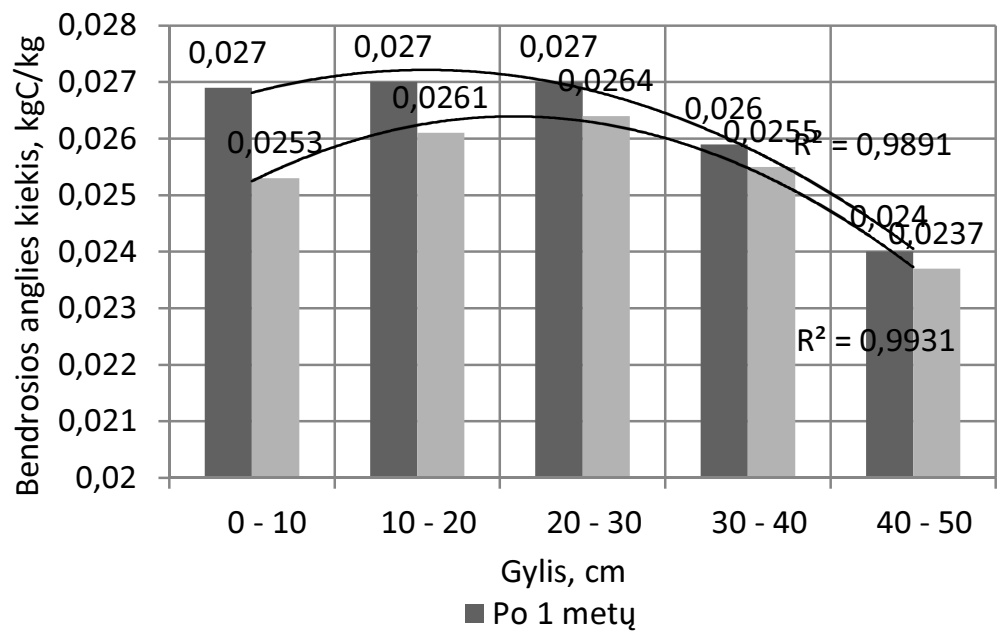

5.20 pav. Bendrosios anglies kiekio pokytis po 10 metų miško dirvožemyje gylyje nuo 0 iki $50 \mathrm{~cm}$, ivertinus klimato itaką

Fig. 5.20. Total carbon change after 10 years of forest soil depths ranging from 0 to $50 \mathrm{~cm}$, the assessment of climate change

Anglies dioksido emisijos priešingai nei pievos dirvožemio esamoje padètyje pirmaisiais metais mažès nuo $1027 \mathrm{kgCO}_{2} / \mathrm{ha} /$ metus iki 565 $\mathrm{kgCO}_{2} /$ ha/metus (sumažès $462 \mathrm{kgCO}_{2} /$ ha/metus) (5.21 pav.). Bet jau nuo antrujų metų anglies dioksido emisijos didès. Dešimtaisiais metais miško dirvožemis išmes $87 \mathrm{kgCO}_{2} /$ ha/metus mažiau. Prognozuojamoje padètyje situacija pasikeičia. Nuo pirmų iki antrų metų stebimas anglies dioksido emisijų augimas 1,2 karto ( $97 \mathrm{kgCO}_{2} /$ ha/metus). Tačiau šis padidejimas yra laikinas. Miško dirvožemis i klimato kaitos itaka kreguoja mažiausiai. Stabilus anglies ciklas leidžia patikimai mažinti anglies dioksida, verčiant ji biomase ir užrakinant dirvožemyje ir medžiuose. Vidutiniškai nuo 3 iki 10 metu anglies dioksido kasmet bus išmetama iki $202 \mathrm{kgCO}_{2} /$ ha/metus. 


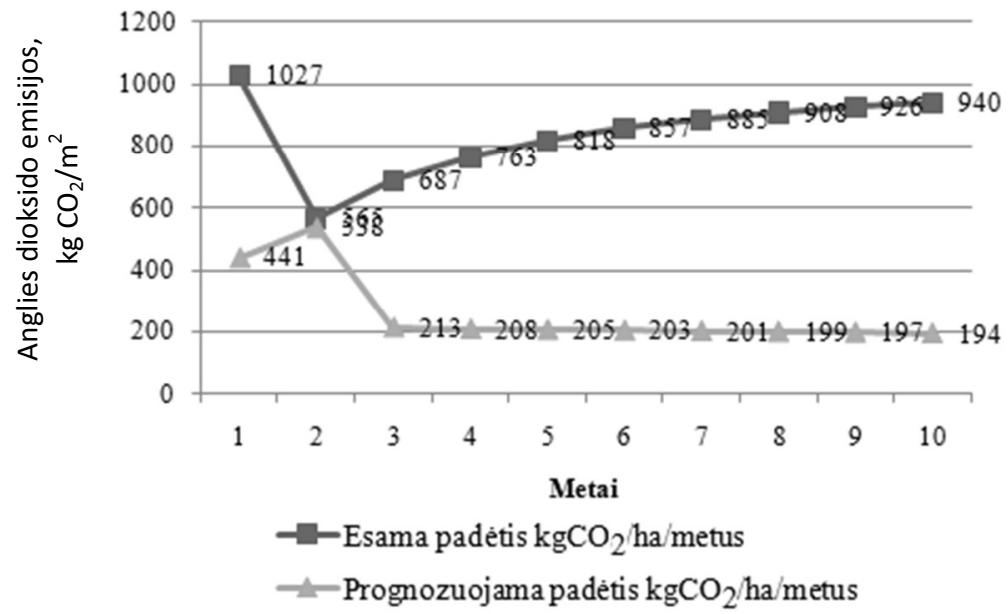

5.21 pav. Anglies dioksido emisjų pokytis miško dirvožemyje po 10 metu, ivertinus klimato kaita

Fig. 5.21. Carbon dioxide emissions from forest soils change after 10 years, the assessment of climate change

Ariamame dirvožemyje dèl mažèjančio bendrosios anglies kiekio anglies dioksido emisijos taip pat yra mažos. O pievos dirvožemyje anglies dioksido emisijos prognozuojamoje padètyje ženkliai padidès, kadangi šis dirvožemis nepasižymi geromis anglies dioksido imobilizavimo galimybėmis.

5.1 lentelè. Bendrosios anglies kiekis nustatytas tyrimais ir sumodeliuotas su DNDC modeliu

Table 5.1. Total carbon amount estimated and modelled with the DNDC model

\begin{tabular}{|c|c|c|}
\hline $\begin{array}{c}\text { Išmatuotas bendrosios } \\
\text { anglies kiekis, } \mathbf{k g C} / \mathbf{k g}\end{array}$ & $\begin{array}{c}\text { Sumodeliuotas bendrosios } \\
\text { anglies kiekis, } \mathbf{~ k g C / k g}\end{array}$ & Skirtumas, \% \\
\hline \multicolumn{3}{|c|}{ Pievos dirvožemis } \\
\hline 0,149 & 0,144 \\
\hline & Ariamas dirvožemis \\
\hline 0,022 & 0,021 & 3,4 \\
\hline \multicolumn{3}{|c|}{ Miško dirvožemis } \\
\hline 0,139 & 0,137 & 1,4 \\
\hline
\end{tabular}


Apskaičiavus gautus natūrinių tyrimų rezultatus nustatyta, kad modeliavimo duomenys pievos dirvožemyje buvo mažesni 3,4\%. Ariamame dirvožemyje sumodeliuotas bendrosios anglies kiekis pievos dirvožemyje buvo mažesnis net $4,5 \%$ tuo tarpu miško dirvožemyje šis skirtumas sieke $1,4 \%$. Vidutinis neatitikimo procentas bendrosios

5.2 lentelè. Anglies dioksido kiekis nustatytas tyrimais ir sumodeliuotas su DNDC modeliu

Table 5.2. Carbon dioxide in the research and modeled whit the DNDC model

\begin{tabular}{|c|c|c|}
\hline $\begin{array}{l}\text { Išmatuotas anglies } \\
\text { dioksido kiekis, } \\
\text { kgCO } / \text { ha }\end{array}$ & $\begin{array}{l}\text { Sumodeliuotas anglies } \\
\text { dioksido kiekis, } \mathrm{kgCO}_{2} / \mathrm{ha}\end{array}$ & Skirtumas, \% \\
\hline \multicolumn{3}{|c|}{ Pievos dirvožemis } \\
\hline 0,149 & 0,185 & 24 \\
\hline \multicolumn{3}{|c|}{ Ariamas dirvožemis } \\
\hline 0,263 & 0,331 & 26 \\
\hline \multicolumn{3}{|c|}{ Miško dirvožemis } \\
\hline 0,139 & 0,176 & 27 \\
\hline
\end{tabular}

Anglies dioksido emisijų kiekių skirtumai tarp tyrimais nustatytų ir nustatytų modeliavimo būdu vidutinis neatitikimo procentas buvo $-26 \%$. Didžiausias duomenų skirtumas nustatytas miško dirvožemio duomenyse ir siekè $27 \%$. Ariamajame dirvožemyje duomenų tyrimo duomenų neatitikimo procentas sieké 26 , o pievos dirvožemyje $24 \%$. Skirtumus tarp nustatytų reikšmių taip pat gali itakoti tai, kad tyrimo rezultatai gauti matuojant tik 11 valandų. Tuo tarpu modelis pateikia visos paros rezultatą. Be to, vertinimui imti tik natūrinių tyrimų laikotarpio vidutinè reikšmè, o ne metinis vidurkis. Apibendrinus tyrimo rezultatus nustatyta, kad modelis pateikia ganėtinai artimas reikšmes, todèl šis modelis gali būti taikytas tolesniuose tyrimuose, dèl savo patikimo modeliavimo ir tyrimo duomenų atitikimo. Autoriai naudojantys ši modelį taip pat pateikia, kad modelis patikimai atspindi skirtingos panaudos dirvožemių anglies pokyčius (Smith 2010, Giltrap 2010).

\subsection{Penktojo skyriaus išvados}

1. Modelio DNDC taikymas leido iqvertinti, tyrimo ir modeliavimo duomenu patikimumą. Dèl mažų paklaidų šis modelis tinkamas vertinti bendrosios anglies kiekius dirvožemyje, o taip pat anglies dioksido emisijas iš dirvožemio. Palyginus gautus modeliavimo duomenis su gautais tyrimų metu nustatyta, kad ben- 
drosios anglies kiekis dirvožemyje nesutampa iki 4,55\%. Sumodeliuoti anglies dioksido emisijų kiekiai su tyrimo duomenimis nesutampa iki $27 \%$.

2. Modeliuojant nustatyta, kad anglies dioksido emisijos yra tiesiogiai priklausomos nuo aplinkos oro temperatūros. Atlikus koreliacines duomenų analizes tarp temperatūros ir anglies dioksido emisijų iš dirvožemių nustatyta, kad pievos dirvožemyje koreliacijos koeficientas siekia 0,5 ariamame dirvožemyje 0,6 , o miško dirvožemyje 0,5 .

3. Imituojant klimato atšilimą ariamajame dirvožemyje nustatytas ryškus bendrosios anglies sumažejjimas praejjus dešimčiai metu nuo $82339 \mathrm{kgC} / \mathrm{ha}$ iki $81887 \mathrm{kgC} / \mathrm{ha}$ (metinis skirtumas mažejjimo skirtumas sieks $452 \mathrm{kgC} / \mathrm{ha}$ ). Taip pat, dèl sumažejusio bendrosios anglies kiekio nustatytas ir daug mažesnis anglies dioksido emisijų išmetimas.

4. İvertinus klimato kaitos poveiki dirvožemiui nustatyta, kad pievos dirvožemyje bendrosios anglies kiekis mažès iki $740 \mathrm{kgC} / \mathrm{ha}$ per pirmuosius metus, o miško dirvožemyje bendrosios anglies padidès iki $937 \mathrm{kgC} / \mathrm{ha}$ per pirmus metus. Ariamajame dirvožemyje bendrosios anglies prarandama daugiausiai iki 830 $\mathrm{kgC} / \mathrm{ha}$ per pirmuosius metus, o dešimtaisiais metais iki $452 \mathrm{kgC} / \mathrm{ha}$, o pievos dirvožemyje dešimaisiais metais mažès iki $542 \mathrm{kgC} / \mathrm{ha}$. Po dešimties metų miško dirvožemyje bendrosios anglies kiekis didès iki $565 \mathrm{kgC} / \mathrm{ha}$. Miško ekosistemos dèl savo stabilaus anglies ciklo, leidžia patikimai mažinti anglies dioksidą, verčiant ji biomase ir užrakinant dirvožemyje bei medžių medienoje.

5. Atlikus anglies dioksido emisijų modeliavimą pievos dirvožemyje nustatyta, $\mathrm{kad}$ emisijų dydis per parą kito nuo $0,06 \mathrm{~kg} \mathrm{CO} / \mathrm{m}^{2}$ iki $4,9 \mathrm{~kg} \mathrm{CO} / \mathrm{m}^{2}$. Ariamame dirvožemyje anglies dioksido emisijos metų bègyje kito nuo 0,18 iki 17,87 $\mathrm{kg} \mathrm{CO}_{2} / \mathrm{m}^{2}$. Miško dirvožemyje sumodeliuotas anglies dioksido emisijų kiekis kito nuo 0,19 iki $7,71 \mathrm{~kg} \mathrm{CO} / \mathrm{m}^{2}$. Vidutinè anglies dioksido emisija yra $2,15 \mathrm{~kg}$ $\mathrm{CO}_{2} / \mathrm{m}^{2}$. Lyginant su ariamo dirvožemio anglies dioksido vidutinèmis emisijomis miško dirvožemis išmeta i atmosferą 2,6 karto mažiau, o su pievos dirvožemiu 1,6 karto daugiau. 


\section{Inžineriniai techniniai sprendimai}

Atliekant lauko tyrimus imami dirvožemio ėminiai. Ėminių paèmimui taikomi ivvairūs metodai ir įrankiai. Pagal pasirinktą èminio tyrimo metodą galimi paèmimo būdai kuomet įvertinama struktūrinè èminio būklè ir kuomet vertinamas tik sudètinių medžiagų kiekinè dalis. Tam, kad paspartinti ėminių paèmimą naudojami įvairių tipų grąžtai, kaltai ir kastuvai. Tradicinis dirvožemio ėminio paèmimo metodas, kai kastuvu iškasama duobè, kurios sieneleje imami dirvožemio èminiai ir nustatomi dirvožemio horizontai. Šis metodas yra vienas iš patikimiausiu tačiau reikalaujantis daug laiko. Jei vertinami tik kiekybiniai dirvožemio parametrai. Geriausia yra naudoti dirvožemio gražtus. Jų forma ir paskirtis bei ėminio paėmimo gylis skiriasi. Yra išskiriami dviejų tipų grąžtai: mechaniniai ir rankiniai. Naudojantis rankiniais grąžtais paėmimo gylis siekia iki 1 metro, priklausomai nuo dirvožemio granuliometrinę sudèties, bei i grąžto formos, ar veikimo principo. Elementariausias grąžto pavyzdys yra išilgai perpjauto vamzdžio dalis. Taip pat naudojami ir cilindriniai grąžtai su gręžimo galvute, bei ivvairiomis modifikacijomis su pusménulinès formos vamzdžiu. Mechaniniai grąžtai taikomi ėminių paèmimui iš gilesnių sluoksnių. Tai pat, šie grąžtai taikomi pamatų statymo arba gruntinio vandens gavimo bei naftos žvalgymo ir gavybos procesuose. 


\subsection{Dirvožemio èminių paèmimo metodika naudojant dirvožemio grąžtą}

Cilindrinis dirvožemio grąžtas su ėminio paèmimo kamera yra patogus irankis norint paimti dirvožemio èmini išvengiant kryžminio užteršimo. Dirvožemio èminiai imami lauko sąlygomis iš ploto, kuris sudalinamas i keletą mažesnių tyrimo vietų. Siekiant užtikrinti dirvožemio analizuojamų parametrų statistinị patikimuma, negalima paimti mažiau nei 9 èminius. Maksimalus dirvožemio ėminių paėmimo kiekis neturètų viršyti 30 vienetų. Tačiau vertinant analizuojamo objekto dydị dirvožemio èminių tankis neturètų būti mažesnis nei vienas kilometras. 30 vienetų ėminių kiekis yra laikomas statistiškai patikimu, pagal statistinès analizès principus, taikomus ėminių analizei. Imamo dirvožemio ėminio gylis priklauso, nuo analizuojamo dirvožemio tipo, bei panaudos. Atsižvelgiant $\mathfrak{i}$ granuliometrinè sudèti siūlomas dirvožemio paèmimo gylis: smèliams iki $10 \mathrm{~cm}$, priesmèliams ir priemoliams iki $20 \mathrm{~cm}$, o moliams iki $30 \mathrm{~cm}$. Kadangi imant dirvožemio ėminius paèmimo gylis tiesiogiai priklauso nuo grą̌žto skersmens, todèl imant iki 1 metro gylio taikytinas kuo mažesnio skersmens grąžtas (skersmuo $\sim 3 \mathrm{~cm}$ ). Gyliams iki $30 \mathrm{~cm}$ gali būti taikomi iki $5 \mathrm{~cm}$ diametro cilindriniai grąžtai. Iki metro gylio taikytini nuo 2 iki $3 \mathrm{~cm}$ diametro rankiniai grąžtai. Ėminių paemimui taikomos èminio kameros. Šis metodas buvo pradètas taikyti moksliniuose tyrimuose analizuojant pirmykštę dirvožemio struktūra, bei sandara. Ėminio paemimui taikomi $10 \mathrm{~cm}$ ilgio kameros. Galimi kamerų tipai: plastikas (atsparus trinčiai, arba vienkartinès paèmimo kameros), nerūdijantis plienas (titano lydinys).

\subsection{Dirvožemio èminių paèmimo grąžto techninis aprašymas}

Siūlomas prietaiso patobulinimas skirtas paimti dirvožemio ėminius. Imant dirvožemi šis grąžtas išsiskiria unikalia savybe paimti èminį iš tam tikro gylio neimant viršutinio sluoksnių. Taipogi šis grąžtas ypatingas tuo, kad èminys imamas i specialų cilindra, kuris gali būti naudojamas kaip ėminio indas, palengvinantis eminių transportavimą. Transportuojant dirvožemio èminius yra svarbu išlaikyti jų struktūra, todèl èminio paèmimas į ėminių cilindrus gali būti plačiai taikomas.

Irenginio vaizdas pateikiamas (6.1 pav.). Grą̌zto išorinè dalis sudaryta iš rankenos, cilindro su išpjova ėminio cilindrui išimti, rankenos prailginimo elementai, papildomos rankenos èminių cilindrui ir gręžimo galvutès fiksavimui ir gręžimo galvutès. 


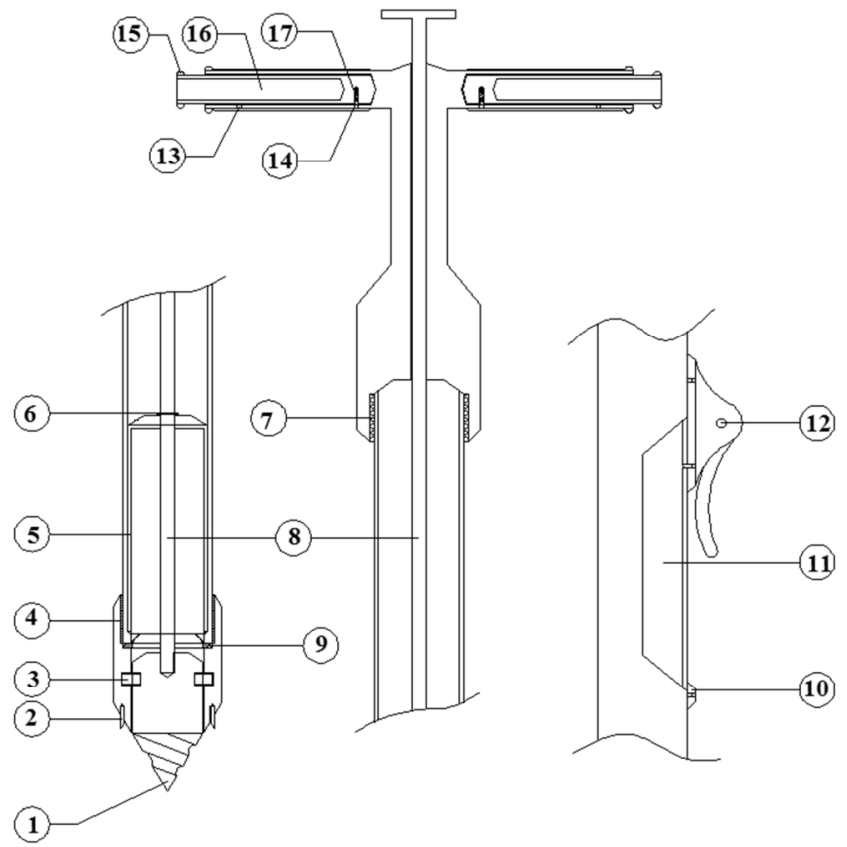

6.1 pav. Dirvožemio ėminių paèmimo grąžtas: 1 - grąžto galva, 2 kietlydinio plokštelès (nupjauti šaknims), 3 - fiksatoriai, 4 stambiasriegis (kairinis), 5 - eminio cilindras, 6 - èminio cilindro fiksatorius, 7 - stanbiasriegis (kairinis), 8 - grąžto galvos valdymo rankena, 9 - èminio fiksatorius, 10 - èminio cilindro dangtelio fiksatorius, 11 - èminio cilindro išèmimo dangtelis, 12 - fiksavimo rankenèlè, 13 - rutulinè fiksavimo ertmè, 14 - šratinis rankenos fiksavimo mechanizmas, 15 - guminis žiedas, 16 - tuščiavidure ištraukiama rankena su fiksavimo mechanizmu, 17 - ištraukiamos rankenos fiksavimo mechanizmas.

Fig. 6.1. Soil sampling drill: 1 - drill-head, 2 - hard alloy plates (cut root), 3 - locking, 4 - thread (left), 5 - cylinder sample, 6 - the sample cylinder lock, 7 - thread (left), 8 - drill head of the operating handle, 9 lock sample, 10 - cover lock of sample cylinder, 11 - sample cylinder cap removal , 12 - locking handle, 13 - Ball locking cavity, 14-ball locking mechanism of the handle, 15 - rubber ring, 16-a hollow retractable handle with locking mechanism, 17 - pull handle locking mechanism. 
Grąžto gręžimo dalys gaminamos iš titaninių ir kietlydinio plokštelių medžiagų, kurios palengvintu šaknu pjovimą. Gręžimo galvutė tvirtinama ant ėminių fiksavimo rankenos kairiniu stambiasriegiu, kuris naudojamas įrenginiuose palengvinant atsukimą ir demontavimą bei įrenginiuose, kurie veikiami didelèmių apkrovų. Gręžimo galvutèje įmontuojami fiksatoriai, kurie užfiksuoja gręžimo padètyje ir neleidžia patekti i dirvožemio èminio cilindro vidų. Gręžimo galvutès kūginèje dalyje suformuotas gręžimo sriegis, palengvinantis grąžto skverbimosi galimybę.

Fiksavimo būdas leidžia neužteršti dirvožemiu analizės kameros ir pagerina gręžimo galimybę, esant gilesniems sluoksniams. Tam, kad dirvožemio ėminys neiškristu imant, naudojamas fiksuojantis žiedas. Žiedo lapeliai gaminami iš spyruoklinio plonasienio metalo arba plastmasès. Fiksuojantysis žiedas su lapeliais fiksuojamas tarp cilindrinès gręžimo karūnèlès ir išorinio grąžto gręžimo cilindro. Cilindrinè gręžimo karūnèlè sudaryta iš cilindro su kietlydinio plokštelèmis, skirtomis nupjauti augalų šaknims. Ant cilindrinès gręžimo karūnèlès išorès yra du iškilimai, kurie naudojami atskirti išorini gręžimo paviršių nuo dirvožemio. Centrinèje grąžto dalyje esanti išpjova naudojama ėminio cilindrui išimti. Dirvožemio ėminys išimamas pakèlus vidinị cilindrą skirta èminių kaupimui. Ėminių paèmimo cilindras fiksuojamas tarp gręžimo galvutès ir fiksatoriaus imontuoto į ėminių cilindro fiksavimo rankeną. Grąžto rankenų viduje įmontuojamos papildomos rankenos padidinančios sukimo momento jègą.

Pagal aprašytą dirvožemio ėminių paèmimo grąžtą yra ruošiama paraiška patentui gauti.

\section{2. Šešto skyriaus išvada}

Siūlomas naujas dirvožemių èminių paèmimo grąžtas gali būti taikomas dirvožemio ėminių paèmimui palengvinti bei išvengti kryžminio užterštumo. 


\section{Bendrosios išvados}

1. Literatūros analizè atskleidè, kad anglies kiekis dirvožemiuose nuolatos mažeja. Labiausiai pažeidžiami yra lengvos granuliometrinès sudèties dirvožemiai. Pagrindinès problemos, sąlygojančios anglies kiekių mažèjimą dirvožemiuose, yra dirvožemio erozija, neracionalus ūkininkavimas, miškų kirtimas. Taip pat atskleista, kad nèra pakankamai vykdomų anglies dioksido emisijų tyrimų arba jie atliekami pasenusiais metodais.

2. Natūriniais tyrimais nustatyta, kad bendrosios anglies kiekiui didelès itakos turi reljefas. Todèl tyrimai atlikti imant ėminius ịvairiuose reljefo aukščiuose. Miško dirvožemyje maksimalus bendrosios anglies kiekis autonominiame landšafte buvo iki $1,5 \%$. Superakvaliniame landšafte bendrosios anglies kiekis buvo iki 5\%. Pievos dirvožemyje maksimalūs bendrosios anglies kiekiai autonominiame landšafte siekè iki 1,6\%, o superakvaliniame landšafte - iki 3,8\%.

3. Ivertinus Neries regioninio parko metinius vidutinius bendrosios anglies kiekius miško dirvožemyje rasta iki 2,4\%, pievos dirvožemyje bendrosios anglies kiekis sieke iki 1,9\%, o ariamajame dirvožemyje bendrosios anglies nustatyta iki $1,7 \%$.

4. Visais analizuojamais laikotarpiais ariamo dirvožemio bendrosios anglies kiekis buvo mažiausias. Palyginus su kitais analizuotais dirvožemiais nustatyta, kad bendrosios anglies kiekis buvo mažiausias lyginant su kitų dirvožemių autonominiais landšaftais. Kovo mènesi vidutinès ariamo dirvožemio bendrosios anglies kiekio reikšmès buvo mažiausios 
už miško dirvožemio bendrosios anglies kieki iki 1,5 karto, o už pievos dirvožemio iki 1,2 karto. Birželio mènesi bendrosios anglies kiekiai ariamame dirvožemyje nežymiai didesni, tačiau jie buvo mažesni 1,2 karto nei miške ir pievoje. Rugpjūčio menesi bendrosios anglies kiekis ariamame dirvožemyje buvo mažiausias. Iki 1,1 karto mažesnis nei miško dirvožemyje ir 1,2 karto mažesnis nei pievos dirvožemyje.

5. Nustatyta, kad dirvožemio profiliuose bendrosios anglies kiekis miško dirvožemyje, nesuardytos struktūros èminiuose, kito nuo 2,4\% iki 3,7\%, o sudètinių èminių profiliuose gylyje iki $30 \mathrm{~cm}$ nuo $1,3 \%$ iki $1,9 \%$. Pievos dirvožemio profiliuose bendrosios anglies kiekiai kinta nuo 6,9\% iki $16,5 \%$, o sudetiniuose éminiuose nuo 3,9\% iki 8,5\%. Atliktais tyrimais ivertinta, kad nesuardytos struktūros èminiai pateikia detalesnę informaciją apie bendrosios anglies kiekius dirvožemyje. Todèl tolesniuose tyrimuose taikyti nesuardytos struktūros eminių ėmimas.

6. Kaip kombinuotais geocheminis barjeras (filtracinis+sorbcinis) dirvožemiuose veikia jų iliuvinis (moliuotais) horizontas, pasižymintis humuso ir sunkiujų metalų akumulialiaciją.

7. Analizuojant anglies dioksido emisijų kiekius skirtingos panaudos dirvožemiuose nustatytas anglies dioksido emisijų kitimas. Žvelgiant i gautus duomenis nustatyta, kad daugiausiai anglies dioksido išsiskiria ariamame dirvožemyje $0,263 \mathrm{~g} \mathrm{CO}_{2} \mathrm{~m}^{-2} \mathrm{~h}^{-1}$,o pievoje $0,149 \mathrm{gCO}_{2} \mathrm{~m}^{-2} \mathrm{~h}^{-1}$ ir miške $0,139 \mathrm{gCO}_{2} \mathrm{~m}^{-2} \mathrm{~h}^{-1}$.

8. Nustatyta, kad dèl dirvožemio drègmès anglies dioksido emisijos mažèja. Natūriniais tyrimais įrodyta, kad pievos dirvožemyje drègniui padidèjus 1,1 karto anglies dioksido emisijos sumažejo 1,2 karto. Ariamo dirvožemio drègniui padidejus 1,4 karto, anglies dioksido emisijos sumažèjo 1,7 karto. Miško dirvožemio drègniui padidejjus 1,4 karto, anglies dioksido emisijos sumažèjo 1,8 karto.

9. Dirvožemio anglies dioksido emisijos turi tiesioginę priklausomybę nuo aplinkos oro temperatūros. Iš atliktų tyrimo rezultatų matyti, kad anglies dioksido emisijos sumažejjusios nuo 1,1 iki 1,6 kartų, nukritus temperatūrai nuo 18,6 iki $8,7^{\circ} \mathrm{C}$ laipsnių.

Atlikus anglies dioksido emisijų modeliavimą pievos dirvožemyje nustatyta, kad emisijų dydis per parą kito nuo $0,06 \quad \mathrm{kgCO}_{2} / \mathrm{m}^{2}$ iki 4,9 $\mathrm{kgCO}_{2} / \mathrm{m}^{2}$. Ariamame dirvožemyje anglies dioksido emisijos metų bėgyje kito nuo $0,18 \mathrm{iki} 17,87 \mathrm{kgCO}_{2} / \mathrm{m}^{2}$. Miško dirvožemyje sumodeliuotas anglies dioksido emisijų kiekis kito nuo $0,19 \mathrm{iki} 7,71 \mathrm{kgCO} / \mathrm{m}^{2}$. Vidutinè anglies dioksido emisija yra $2,15 \mathrm{kgCO}_{2} / \mathrm{m}^{2}$. Lyginant su ariamo dirvožemio anglies dioksido vidutinèmis emisijomis miško dirvožemis išmeta i atmosferą 2,6 karto mažiau, o su pievos dirvožemiu 1,6 karto daugiau. 


\section{Rekomendacijos}

1. Analizuojant bendrosios anglies kiekius būtina atsižvelgti ị reljefo padètí, bei ịvertinti dirvožemio erozijos padarinius bendrosios anglies kiekiams. Tyrinèjant kalvotas vietoves patartina imti dirvožemio ėminius ne tik autonominiame landšafte, bet ir superakvaliniame.

2. Tyrinèjant anglies dioksido emisijas būtina atsižvelti ị meteorologines sąlygas, o ypač i lietų. Jei dirvožemis labai įmirkęs nustatytos anglies dioksido emisijos yra mažesnès. Tyrimus patartina atlikti po kelių dienų kai normalizuojasi dirvožemio drègnis.

3. Modelio gautų duomenu kitimo ribos lyginant su tyrimo duomenimis mažos, todèl šį modeli galima taikyti tolesniems tyrimams. 



\section{Literatūra ir šaltiniai}

Adams, J.M.; Faure, H.; Faure-Denard, L.; McGlade, J.M.; Woodward, F.I.; 1990. Increases in terrestrial carbon storage from the last glacial maximum to the present, Nature 348(6303): 711-714.

Antanaitis, A.; Tamulis, T.; Žemaitis, A. 1996. Mikroelementai dirvožemyje ir augaluose, Žemès ūkio mokslai 2: 53-59. Vilnius.

Apalia, Dz.; Vaitiekūnas, J.; Visockis, O. ir kt. 1982. Augalai - dirvožemio reakcijos (pH) indikatoriai. Vilnius. 183 p.

Arlauskienė, A.; Maikštėnienè, S. 2002. Molingų dirvožemių savybių gerinimas ankštiniais augalais jų biomasę panaudojant žaliajai trąšai, Žemdirbystè: mokslo darbai LŽI, $L \check{Z} \bar{U} U$, . 79: 229-243. Akademija

ASA 1990. Impact of carbon dioxide, trace gases, and climate change on global agriculture, Am. Soc. Agron., Spec. Publ. 53. Madison. 133 p.

ASA 1993. Agricultural ecosystem effects on trace gases and global climate change. Am. Soc. Agron., Spec. Publ. 55 Madison, 206 p.

Baginskas, B.; Žemaitis, A.; Narkevičius, J. ir kt.1984. Agrochemija. Vilnius.: Mokslas. $214 \mathrm{p}$. 
Bakšienè, E. 2004. Ilgalaikis sapropelio poveikis priesmèlio paprastajam išplautžemiui (Haplic Luvisols), Vandens ūkio inžinerija: mokslo darbai 26 (46): 71-75. Kaunas Akademija.

Bakšienè, E.; Janušienė, V. 2006. Sapropelio įtaka dirvožemių agrocheminėms savybėms ir humuso sudéčiai, in Tręšimas: Mokslinių straipsnių rinkinys LŽL-DotnuvaAkademija, 9-33.

Baldock, J. A.; Skjemstad, J. O. 1999. Soil organic carbon soil organic matter, in Soil Analysis - an Interpretation Manual. Vic. Australia. 265 p.

Batjes, N. H. 1996. Total carbon and nitrogen in the soils of the world, Eur. J. Soil. Sci. 47(2): 151-163.

Batjes, N. H.; Dijkshoorn, J. A. 1999. Carbon and nitrogen stocks in the soils of the Amazon region, Geoderma 89: 273-286.

Bazzaz, F.; Sombroek, W. 1997. Changements du Climat et Production Agricole. FAO, Rome/Polytechnica, Paris. 406 p.

Beliauskas, B. 1976. Mèšlo veikimas eroduojamuose Šiaurès Rytų Lietuvos velèniniuose jauriniuose priemoliniuose dirvožemiuose, LŽI mokslo darbai 20: 17-34.

Bennema, J. 1974. Organic carbon profiles in oxisols, Pédologie 24(2): 119-146.

Berger, A.; Loutre, M. F. 1996. Modelling the climate response to astronomical and $\mathrm{CO}_{2}$ forcings, Acad. Sci. Paris, Ser. 323(1): 1-16.

Bieliauskas, P. 1985. Dirvosauginè žemdirbystė kalvose. Vilnius. 88 p.

Birietienè, Z. 1984. Eroduojamų velèninių jaurinių dirvožemių mineralinè sudètis, $L Z ̌ I$ mokslo darbai. Dirvotyra 32: 123-132.

Bohn, H. L. 1976. Estimate of organic carbon in world soils, Soil Sci. Soc. Am. J. 40: $468-470$.

Brady, N. C.; Weil, R. R. 1999. The Nature and Properties of Soils. Prentice Hill, Upper Sadle River, New Jersey: 321 .

Braukyla, J. 1984. Erozijos procesai Lietuvos TSR dirvožemiuose, LŽI mokslo darbai. Dirvotyra 32: 101-110.

Bridges, E. M.; Betjes, N. H.; Nachtergalele, F.O. 1998. World Reference Base for Soil Resourses. Atlas. Acco Leuven/Amersfoort, 79 p. 
Brown, S.; Lugo, A. E. 1982. The storage and production of organic matter in tropical forests and their role in the global carbon cycle, Biotropica 14(3): 161-187.

Buivydaitè, V.; Vaičys, A.; Juodis, J. 1990. Lietuvos dirvožemių klasifikacija suderinta su FAO-Unesco pasaulio dirvožemių žemėlapio legenda, iš Dirvotyros ir agrochemijos pasiekimai ir uždaviniai žemès reformos bei perèjimo ì rinkos ekonomika metu. Mokslinès konferencijos, skirtos Lietuvos dirvožemininku draugijos 40-mečiui, pranešimai.Kaunas: 7-27.

Buivydaite, V.; Vaičys, M.; Juodis, L.; Motuzas, A. 2001. Lietuvos dirvožemiu klasifikacija. Vilnius. 137 p.

Bukantis, A.; Gulbinas, Z.; Kazakevičius, K. ir kt. 2001. Klimato svyravimu poveikis fiziniams geografiniams procesams Lietuvoje. Vilnius: Geografijos institutas, Vilniaus universitetas. $68 \mathrm{p}$.

Bundinienė, O. 1998. Mèšlo ir mineralinių trąšų įtaka augalų derliui ir dirvos derlingumui kalvotose Rytų Lietuvos dirvose, Žemès ūkio mokslai 2: 7-12.

Bundinienė, O. 2000. Ivairaus chemizavimo lygio žemdirbystės sistemos erozijos procesai ir dirvožemio pokyčiai. Augalininkystè kalvoto reljefo sąlygomis, iš Agronominiai, ekonominiai ir ekologiniai aspektai. LŽI. 102 p.

Bundinienè, O.; Paukštè, V. 2002. Lietuvos žemdirbystès instituto bandymų stoties veikla 1960-2000 m., Žemès ūkio mokslai 4:45-53. Vilnius.

Bužas, A.; Doruman, C.; Arbaliauskas, Č. 1966. Lietuvos klimatas. Vilnius. 159 p.

Čaikauskas, V. 1985. Augalininkystè. Vilnius. 320 p.

Danilevičius, V.; Matulevičius, I.; Motuzas, A. 1977. Dirvožemio mokslas ir geologijos pagrindai. Vilnius. $45 \mathrm{p}$.

Danilevičius, V.; Matulevičius, J.; Motuzas, A. 1977. Organiné dirvožemio dalis. Dirvožemio mokslas ir geologijos pagrindai. Vilnius: Mokslas, 12-136.

Dirvožemio agrocheminio tyrimo medžiaga 1963-1993. Respublikos ūkių agrocheminio tyrimo bylos, rajoninès suvestinès. Agrocheminių tyrimų centro archyvo fondai. Kaunas. $125 \mathrm{p}$.

DNDC user guide. [Žiūrèta $2010 \mathrm{~m}$. balandžio 17 d.] Prieigą per internetą: $<$ http://www.dndc.sr.unh.edu/?page_id=4>.

Eitminavičiūtè, I. 1997. Dirvožemio biologija (pedobiologija). Vilnius. 122 p. 
Ežerinskas, V. 1996. Perspektyvios kalkinès medžiagos ir dirvų kalkinimas, Agronomijos ir gyvulininkystès mokslu aktualijos. Kaunas: Akademija, 234-239.

Feiza, V. 2004. Žemés dirbimas neariant. Arimo teorija ir praktika. Kaunas: Akademija. $280 \mathrm{p}$.

Feizienè, D.; Feiza, V.; Kadžienè, G. 2009. Meteorologinių sąlygų itaka dirvožemio vandens garu srauto intensyvumui ir $\mathrm{CO}_{2}$ emisijai taikant skirtingas žemès dirbimo sistemas, Žemdirbysté-Agriculture 96(2): 3-22. ISSN 1392-3196.

Feizienè, D.; Kadžienè, G. 2008. The influence of soil organic carbon, moisture and temperature on soil surface $\mathrm{CO}_{2}$ emission in the 10th year of different tillage-fertilisation management, Zemdirbyste-Agriculture 95(4): 29-45. ISSN 1392-3196.

Garten, Jr. C. T.; Cooper, L. W.; Post, III W. M.; Hanson, P. J. 2000. Climate controls on forest soil $\mathrm{C}$ isotope ratios in the southern Appalachian Mountains, Ecology 81: $1108-1119$.

Garten, Jr. C. T.; Post, III W. M.; Hanson, P. J.; Cooper, L.W. 1999. Forest soil carbon inventories and dynamics along an elevation gradient in the southern Appalachian Mountains, Biogeochemistry 45: 115-145.

Giltrap, D. L.; Li, C.; Saggar, S. 2010. DNDC: A process-based model of greenhouse gas fluxes from agricultural soils, Agriculture, Ecosystems and Environment 136: 292230 .

Griciūtè, A.; Kavaliauskas, B.; Tomkus, J. 1979. Lietuvos antropoklimatas. Vilnius. $125 \mathrm{p}$.

Grigaliūnienè, K. 2005. Ilgalaikio tręšimo poveikis skirtingos kilmès dirvožemių biologiniam aktyvumui. Daktaro disertacija, Kaunas. 102 p.

Hagedorn, F.; Maurer, S.; Egli, P.; Bucher, J. B.; Siegwolf, R. 2001. Carbon sequestration in forest soils of soil type, atmospheric $\mathrm{CO}_{2}$ enrichment and $\mathrm{N}$ deposition, European Journal of Soil Science 52: 619-628.

Hanson, P. J.; Edwards, N. T.; Garten, Jr. C. T.; Andrews, J. A. 2000. Separating root and soil microbial contributions to soil respiration: a review of methods and observations, Biogeochemistry 48: 115-146.

Ingram, J. S. I.; Fernandes, E. C. M. 2001. Managing carbon sequestration in soils: concepts and terminology, Agriculture, Ecosystems and Environment 87: 111-117. 
IPCC, Climate Change. 2001. The Scientific Basis. Summary for Policy makers. Third Assessment Report. Geneva. 98 p.

Jankauskas, B. 1996. Dirvožemio erozija. Vilnius. 161 p.

Jankauskas, B.; Jankauskiene, G.; Fullen, M. A. 2004. Erosionpreventive crop rotations and water erosion rates on undulating slopes in Lithuania, Canadian Journal of Soil Science 84(2): 177-186.

Jankauskas, B.; Jankauskaienė, G. 2003. Stacionariniai dirvožemio erozijos tyrimai Žemaičių aukštumoje. 1. Dirvožemis ir jo savybès, Žemdirbystė 82: 3-19. LŽI, LŽŪU mokslo darbai. Akademija.

Jankauskas, B.; Jankauskiene, G. 2003. Erosion-preventive crop rotations for landscape ecological stability in upland regions of Lithuania, Agriculture, Ecosystems and Environment 95: 129-142.

Jankauskas, B.; Jankauskienė, G. 2004. Water erosion rates on slopes under different land use systems, Žemés ūkio mokslai 3: 1-7.

Jankauskas, B.; Jankauskienè, G. 2006. Kiekybiniai eroduojamų dirvožemių organinès medžiagos pokyčiai dèl skirtingos žemès naudojimo, Dirvotyra ir agrochemija 4: 1-10.

Jankauskas, B.; Šlepetienė, A.; Jankauskienè, G.; Fullen, M. A.; Booth, C. A. 2005. Organinès medžiagos analizavimo metodų palyginimas ir duomenų matematinio perskaičiavimo galimybè, Žemès ūkio mokslai 3: 1-7.

Janušienè, V. 1992. Antropogeniniu veiksniu jtaka humuso kiekiui ir jo sudèčiai. Antropogeniniu veiksniu itaka dirvožemio derlingumui. Vilnius. 234 p.

Janušienė, V. 1994. Biologinė medžiagų apykaita, jos poveikis dirvodarai ir dirvožemio derlingumui, Žemés ükio mokslai 5: 14-118.

Janušienè, V.; Žekonienè, V. 2004. Žaliosios trąšos poveikis humuso bei mineralinio azoto pokyčiams priesmèlio dirvožemyje, Žemès ūkio mokslai 4: 1-6.

Jenkyn, I. F.; Christian, D. G.; Bacon, E. T. G. 2001. Effect of incorporating different amounts of straw on growth diseases and yield of consecutive crops of winter wheat grown on contrasting soil types, The Journal of Agricultural Science 136: 1-14.

Jones, R.; Houšková, B.; Bullock, P.; Montanarella, L. 2005. Soil Resources of Europe, second edition. European Soil Bureau Research Report No. 9, EUR 20559 EN, 420 p.

Kaboneka, S.; Nivviza 1, C.; Sibomana, L. 2000. Effects of Nitrogen and Phosphorus Fertilizer Addition on Wheat Straw Carbon Decomposition in a Burundi Acidic Soil 
[Žiūreta $2010 \quad$ m. vasario 19 d.] Prieiga per internetą: $<$ http://www.tsbf.org/managing_nutrient_cycles>.

Kiburys, B. 1995. Mechanical soil-erosion caused by tillag of 5, 10 and $15^{\circ}$ slopes, Žemès ūkio mokslai 4: 10-13.

Kogut, B. M. 1998. Transformation of humus status in cultivated Chernozems, Eurasian Soil Science 7: 721-728.

Krištaponytė, I. 1996. Tręšimo sistemų palyginimas sunkios granuliometrinės sudèties dirvožemiuose, Žemdirbystè, mokslo darbai, LŽI. Dotnuva-Akademija. 56: 54-63.

Krištaponytė, I. 2002. Trę̌simo i̇taka dirvožemio fizikinių savybių pokyčiams ir augalų derlingumui, Žemdirbysté: mokslo darbai, LŽI, LŽŪU. Akademija. 5: 244-265

Kutzbach, L.; Schneider, J.; Sachs, T.; Giebels, M.; Nykanen, H.; Shurpali, N. J.; Martikainen, P. J.; Alm, J.; Wilmking, M. 2007. $\mathrm{CO}_{2}$ flux determination by closed-chamber methods can be seriously biased by inappropriate application of linear regression, Biogeosciences 4: 1005-1025. ISSN: 1726-4170 IF=3,246.

Lal R.; Kimble, J. M.; Follett, R. F.; Stewart, B. A. 1998. Soil Processes and the Carbon Cycle. Boca Raton: CRC Press. 609 p.

Lal, R. 2004. Soil carbon sequestration impacts on global climate change and food security. Soils - the final frontier (Special section), Sience 304: 623-1627.

Lampkin, N. 1999. Organic Farming. Tonbridge: Farming Press. 715 p.

Liaudanskienė, I.; Šlepetiènè, A.; Velykis, A. 2010. Fiziškai nestabilių dirvožemio organinès medžiagos frakcijų anglies pokyčiai dèl tausojamo žemès dirbimo, LŽŪU mokslo darbai 88(41): 38-43.

Lietuvos dirvožemiai 2001. Lietuvos mokslas, kn. 32. Vilnius. 1244 p.

Lietuvos miškų instituto 2009 metų veiklos apžvalga. [Žiūrèta 2010 m. kovo 19 d.] Prieigą per internetą: <http://www.mi.lt/info/LMI-2009.pdf>.

Lipson, D. A.; Schmidt, S. K. 2000. Carbon availability and temperature control the post-snowmelt decline in alpine soil microbial biomass, Soil Biology And Biochemistry 32(4): 441-448.

Lohnston, A. E. 1986. Soil organic matter, effect on soil and crops, Soil Use and Management 2(3): 97-105. 
Mažvila, J. 1998. Lietuvos dirvožemiu agrocheminès savybès ir ju kaita: monografija. Akademija. 19 p.

Mažvila, J.; Vaišvila, Z.; Radžiūnas, V. 1992. Ilgalaikio tręšimo mineralinėmis trąšomis itaka derliui, dirvožemio agrocheminėms savybėms, maisto medžiagu išplovimui, iš Antropogeniniu veiksni乇 Ł̇taka dirvožemio derlingumui Vilnius,: 52-56.

McGuire, A. D.; Appsm M.; Chapinm III F. S.; Dargavillem, R.; Flanniganm, M. D.; Kasischkem, E.S.; Kicklighterm, D.W.; Kimballm, J.; Kurzm, W.; McCraem, D.J.; McDonaldm, K.; Melillo, J.M.; Myneni, R.; Stocks, B.J.; Verbyla, D.L.; Zhuang, Q. 2004. Canada and Alaska, in, Land Change Science: Observing, Monitoring, and Understanding Trajectories of Change on the Earth's Surface 23: 236-598.

Motuzas, A.; Buivydaitè, V.; Danilevičius, V. 1996. Dirvotyra. Vilnius,: Mokslo ir enciklopedijų leidykla. 285 p.

Motuzas, J.; Buivydaitè, V.; Šleinys, V. 1996. Dirvotyra. Vilnius. 155 p.

Nelson, D. W.; Sommers, L. E. 1982. Total carbon, organic carbon and organic matter, In, Page, A. L. (Ed.). ASA Monograph. Madison, Wisconsin USA: 579 p.

Neries regionino parko žemėlapis. [Žiūrèta $2008 \mathrm{~m}$. birželio 9 d.] Prieigą per internetą: $<$ http://www.neriesparkas.lt/?id=52\&l=1 $>$.

Olesen, J. E.; Bindi, M. 2002. Consequences of climate change for European agricultural productivity, land use and policy, European Journal of Agronomy 16: 239-262.

Ollinger, S. V.; Aber, J. D.; Reich, P. B. 1996. Predicting the effects of tropospheric ozone on forest productivity in the northeastern U.S, In. Proceedings, 1995 Meeting of the Northern Global Change Program, USDA USFS General Technical Report NE-214, 217-225.

Ollinger, S. V.; Aber, J. D.; Reich, P. B.; Freude, R. J. 2002. Interactive effects of tropospheric ozone, nitrogen deposition, elevated $\mathrm{CO}_{2}$ and land use history on the carbon dynamics of northern hardwood forests, Global Change Biology 8: 545-562.

Organic Agriculture, Environment and Food Security. 2002. Edited by Nadia El-Hage Scialabba and Caroline Hattam, Environment and Natural Resources Series Rome. $252 \mathrm{p}$.

Partyka, T.; Hamkalo, Z. 2010. Estimaation of oxidizing of organic matter of forest and arable soil, Žemdirbystè 97(1): 33-40.

Paškauskas, S. 2001. Vèjiné dirvožemio erozija. Lietuvos dirvožemiai. Vilnius: Lietuvos mokslas, 32 knyga. 719 p. 
Postek, K. M.; Driscoll, C. T.; Aber, J. D.; Santore, R. C. 1995. Application of PnETCN/CHESS to a spruce stand in Solling, Germany, Ecological Modeling 83:163-172.

Račinskas, A. 1990. Dirvožemio erozija. Vilnius. 136 p.

Ruddiman, W. F. 2003. The anthropogenic greenhouse era began thousands of years ago, Climate Change 61(3): 261-293.

Saulius M. 2007. Ariamų žemių renatūralizacija: poveikis dirvožemio armens agrocheminiams rodikliams, Žemès ūkio mokslai Lietuvos mokslų akademijos leidykla, 14(2): $18-22$.

Smith, W. N.; Grant, B.B.; Desjardins R. I.; Worth, D.; Li, C.; Boles, E. C.; Huffman, E. C. 2010. A tool to link agricultural activity data with the DNDC model to estimate GHG emission factor in Canada, Agriculture, Ecosystems and Environment 136: 301-309.

Soil Atlas of Europe. 2005. European Soil Bureau Network. 128 p.

Šleinys, R. 1994. Pažinkime dirvožemi. Dotnuva-Akademija. 189 p.

Tylienè, E. 1974. Daugiamečių ankštinių žolių parinkimas Aukštaitijos kalvoms, LŽI mokslo darbai. Žoliu ūkis (17): 47-56.

Tripolskaja, L. 2005. Organinès trąšos ir ju poveikis aplinkai. Lietuvos žemdirbystè. Vilnius. 324 p.

Vaišvila, Z. 1999. Agrochemija. Kaunas. 337 p.

Verma, S. B.; Dobermann, A.; Cassman, K. G.; Walters, D. T.; Knops, J. M.; Arkebauer, T. J.; Suyker, A. E.; Burba, G. G. 2005. Annual carbon dioxide exchange in irrigated and rainfed maizebased agroecosystems, Agricultural and Forest Meteorology 131: 77-96. ISSN: 0168-1923 IF=3,197.

Volungevičius, J.; Prapiestienè, R.; Eidukevičienè, M. 2006. Dirvožemio pH erdvinių dèsningumų Lietuvoje pagrindimas, Geografija 42(2): 8-14.

Žalakevičius, M. 2005. Globalios klimato kaitos poveikis ekosistemoms ir ju sudedamosioms dalims: jautrumas, pažeidžiamumas, adaptacijos. Vilnius. 67 p.

Žemès dirbimo įtaka dirvožemio kokybei. [Žiūrèta 2010 m. gegužès 14 d.] Prieigą per internetą: <http://www.manoukis.lt/print_forms/print_st_z.php?s=2147\&z=96>.

Алексеев, Ю. В. 1987. Тяжелье металль в почвах и растениях. Москва. 136 с. 
Анспок, П. И.; Лиепиньш, Ю. Я. 1991. Сапропели - источник органического вещества, макро и микроэлементов, Химия 4: 42-45.

Бабров, С. А. 1981. Биологическая доступность питательных веществ в почве. Москва. 296 с.

Богдевич, П.; Пироговская, Г.; Русалович, А. 1998. Миграция веществ в почвах Белорус в зависимости от уровня минерального питания растений и форм удобрений, в кн.: Лизиметрические исследования почв: материалы научной конференции МГУ. Москва, 208.

Богдезич, М. 2000. Проблемы плодородия почв Белорус. Почва, удобрение, плодородие: материалы научной конференции. Минск, 25-46.

Возбуцкая, А. Е. 1964. Химия почвы. Москва: Высшая школа. 398 с.

Воронин, А. Д. 1986. Основы физики почв. Москва. 242 с.

Гилярова, М. С. 1975. Методы почвенно-зоологических исследований. Москва. $275 \mathrm{c}$.

Гуев, Н. А. 1989. Микробиологические прочессы гумусообразовання. Москва. 237 с.

Мартинчик, Т.Н. 2001. Влияние альтернативных источников органических удобрений на продуктивность звена севооборота и баланс элементов питания: автореф. дис. ... канд. с.-х. наук. Минск. 321 с.

Мипчинк, Т. Г. 1979. Почвенная микробиология. Москва. 316 с.

Мишустин, Е. Н.; Емцев, В.Т. 1978. Микробиология. Москва. 166 с.

Орлов, Д. С. 1990. Гумусовые кислоты почв и общая теория гумификации. Москва. 375 с.

Эйдукявичене, М. 1993. Геохимическое и географическое обоснование оптимизирования известкования кислых почв Литвы: автореф. ... д-ра наук. Вильнюс. 266 с.

Ягодина, Б. А. 1982. Агрохимия. Москва: ВО Агропромиздат. 287 с. 



\section{Autoriaus publikacijos disertacijos tema}

\section{Straipsniai mokslo recenzuojamuose žurnaluose}

Baltrènas, P.; Pranskevičius, M.; Lietuvninkas, A. 2010. Research and assesment of dependences of the total carbon on $\mathrm{pH}$ in Neris regional park, Journal of Environmental Engineering and Landscape Management 18(3): 179-187 (ISI Web of Science) $\mathrm{IF}=1,508 \mathrm{AIF}=2,476 \mathrm{ISSN}$ : 1648-6897.

Baltrènas, P.; Pranskevičius, M.; Lietuvninkas, A. 2010. Investigation and evaluation of carbon dioxide emissions from soil in Neris regional park, Journal of Environmental Engineering and Landscape Management 19(1): 115-122. (ISI Web of Science) $\mathrm{IF}=1,508$ AIF=2,476 ISSN: 1822-4199.

Pranskevičius, M.; Baltrènas, P. 2009. Reljefo ịtakos bendrosios dirvožemio anglies kitimui tyrimas ir vertinimas [Research and evaluation of relief effect on total carbon changes in soil], Mokslas - Lietuvos ateitis 1(4): 4-14 p. ISSN. 2029-2252. 


\section{Straipsniai kituose leidiniuose}

Baltrẻnas, P.; Pranskevičius, M.; Lietuvninkas, A. 2008. A. Investigation and evaluation of total organic carbon in soil, in The $7^{\text {th }}$ International Conference Environmental Enginiering I: 42-51. ISBN. 978-9955-28-263-1.

Pranskevičius, M.; Baltrẻnas, P. 2008. Bendrosios organinės anglies dirvožemyje vertinimas [Total organic carbon in the soil evaluation], iš 11-osios Lietuvos jaunuju mokslininku konferencijos „Mokslas - Lietuvos ateitis”, ivykusios Vilniuje 2008 m. balandžio $3 \mathrm{~d}$., straipsniu rinkinys [elektroninis išteklius] [Environmental Engineering Proceedings of the XI Conference of Lithuanian Young Scientists „Science - the future of Lithuania“, held in Vilnius on 3 April, 2008 [CD]]. Aplinkos apsaugos inžinerija. Vilnius: Technika: 170-178. ISBN 978-9955-28-385-0. 
Mantas PRANSKEVIČIUS

SKIRTINGOS ŽEMĖNAUDOS DIRVOŽEMIU BENDROSIOS ANGLIES KIEKIO IR ANGLIES DIOKSIDO EMISIJOS TYRIMAI BEI VERTINIMAS

Daktaro disertacija

Technologijos mokslai,

aplinkos inžinerija ir kraštotvarka (04T)

RESEARCH AND ASSESSMENT OF THE TOTAL CARBON CONTENT AND CARBON DIOXIDE EMISSIONS FROM SOILS OF DIFFERENT LAND-USE PURPOSE

Doctoral Dissertation

Technological Sciences,

Environmental Engineering (04T)

201105 05. 13,25 sp. I. Tiražas 20 egz.

Vilniaus Gedimino technikos universiteto

leidykla "Technika“,

Saulètekio al. 11, 10223 Vilnius,

http://leidykla.vgtu.lt

Spausdino UAB "Ciklonas“

J. Jasinskio g. 15, 01111 Vilnius 